\begin{tabular}{|l|l|}
\hline 2. To: (Receiving Organization) & $\begin{array}{l}\text { 3. From: (Originating organization) } \\
\text { TWRS Projects/SST Retrieva1 }\end{array}$ \\
\hline 5. Proj./Prog./Dept./Div.: D299/ & $\begin{array}{l}\text { 6. Design Authority/ Design Agent/Cog. } \\
\text { Engr:: } \\
\text { W-320 TWRS/TCPN \# Bailey, NHC }\end{array}$ \\
\hline
\end{tabular}

8. Originator Remarks:

For approval and release of a new supporting document. This document has been generated to ensure retrievability of the Project W-320 "Piping Calculations, Vol. 7".
11. Receiver Remerks:
[X] Yes [] No

4. Related EOT No.:

$n / a$

7. Purchase Order No.:

$n / a$

9. Equip./Component No.:

$n / a$

10. Systen/8ldg./Facility:

$241-C-106$

12. Major Assm. Dwg. No.:

\section{$n / a$}

13. Permit/Permit Application No.: $n / a$

14. Required Response Date:

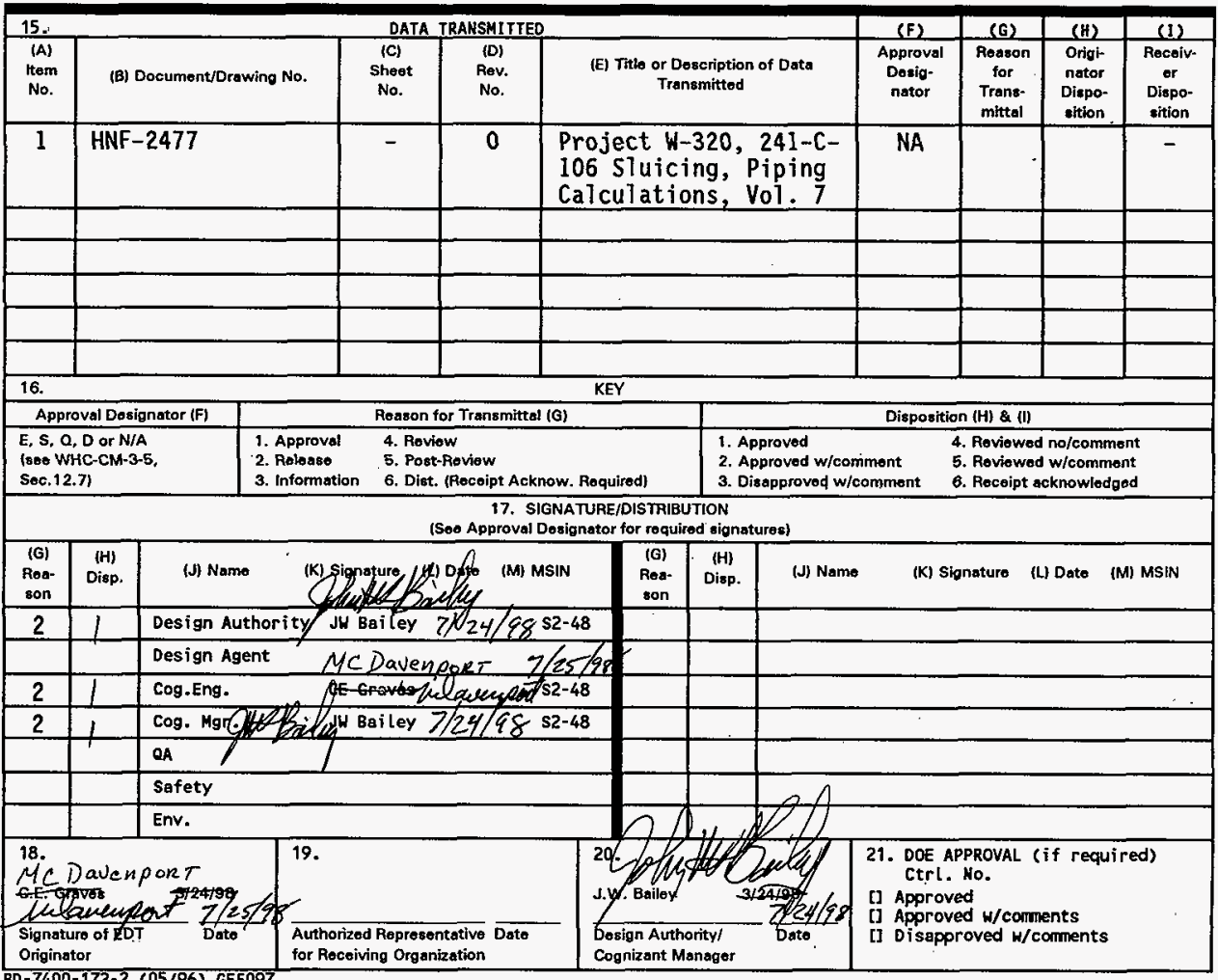


HNF-2477, Rev, 0

\section{Project W-320, 241-C-106 Sluicing Piping Calculations, Vol. 7}

John W. Bailey

Numatec Hanford Co., Richland, WA 99352

U.S. Department of Energy Contract DE-AC09-96RL13200
EDT/ECN: 622235
UC: 506
Org Code: 8C452
Charge Code: D2991/HANA0600
B\&R Code: EW3130010
Total Pages: 220

Key Words: W-320, S1uicing, Tank 241-C-106, Tank 241-AY-102, WRSS, calculations, piping.

Abstract: This supporting document has been prepared to make the FDNW calculations for Project $W-320$, readily retrievable. Product cut sheets in this document have been reviewed and are not
Copyrighted.

\footnotetext{
TRADEMARK DISCLAIMER. Reference herein to any specific comercial product, process, or service by trade name, trademark, manufacturer, or otherwise, does not necessarily constitute or imply its endorsement, recommendation, or favoring by the United States Government or any agency thereof or its contractors or subcontractors.

Printed in the United States of America. To obtain copies of this document, contact: Document Control Services, P.O. Box 950, Mailstop H6-08, Richland WA 99352, Phone (509) 372-2420; Fax (509) 376-4989.
}
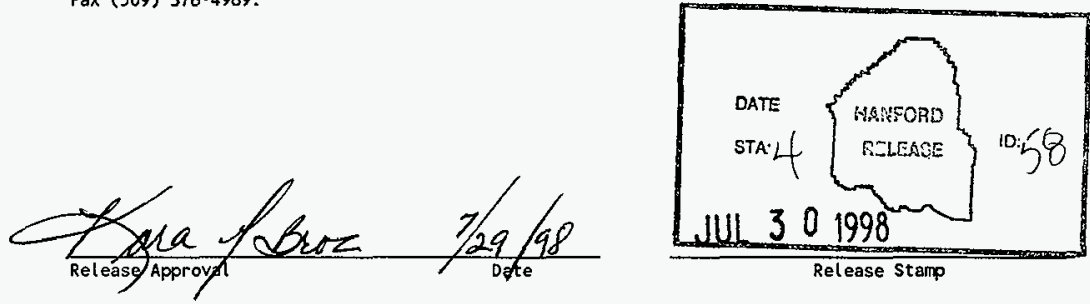
HNF-2477, Rev. 0

\title{
Project W-320, 241-C-106 Sluicing Piping Calculations, Vol. 7
}

\author{
TABLE OF CONTENTS
}

Calc. No.

W320-27-044

W320-27-045

W320-27-046

W320-27-047
Title

Sluicer Nozzle Force Analysis

Pipe Drain Flow and Anti-Siphon

Sizing for Transfer Lines

Flushing Nozzle Lifting Force

W-320 Pit Volumes and In-Out Areas
Page

$A-i$

B-i

$c-i$

D- $\mathbf{i}$ 
HNF-2477, Rev. 0

W320-27-044

Sluicer Nozzle Force Analysis

A- $i$ 
FLUOR DANIEL

NORTHWEST

This sheet shows the status and description of the attached Design Analysis sheets.

Discipline 27, Piping and Vessels WO/Job No. W320/ER9142 Calculation No. W320-27-044

Project No. \& Name Project $W-320$ Waste Retrieval for Tank 241-C-106

Calculation Item SIUICER NOZZLE FORCE ANALYSIS

These calculations apply to:

Dwg. No. H-2-818551 and $\mathrm{H}-2-818555$

Dwg. No.

Other (Study, CDR)

Rev. No.

Rev. No. 1

Rev. No.

The status of these calculations is:

$\square$ Preliminary Calculations

区 Final Calculations supersedes calc. $13320-27-033$

$\square$ Check Calculations (On Calculation Dated

$\square$ Void Calculation (Reason Voided

Incorporated in Fina! Drawings?

This calculation verified by independent "check" calculation? [x] Yes

Yes 


\section{CALCULATION CROSS INDEX (Typical)}

Subject Calculation No. W320-27-044

\begin{tabular}{|c|c|c|c|}
\hline $\begin{array}{l}\text { Subject } \\
\text { Calculation } \\
\text { Revision }\end{array}$ & $\begin{array}{l}\text { Superceded } \\
\text { by } \\
\text { Calculation }\end{array}$ & $\begin{array}{c}\text { These interfacing calculation/documents } \\
\text { provide input to the subject calculation, } \\
\text { and if revised may require revision of } \\
\text { the subject calculation. }\end{array}$ & $\begin{array}{c}\text { Results and conclusions of the subject } \\
\text { calculation are used in these } \\
\text { interfacing calculations and/or } \\
\text { documents. }\end{array}$ \\
\hline
\end{tabular}

Does the output $/$ Has the output

Revision Calculation the subject calculation. documents.

documents require

documents been

No.

No. Calcualtion/Document No.

Revision.

Calcualtion/Document No. Revision. No

revision?

revised?

Discipline manager's signature and date indicating evaluation

complete.

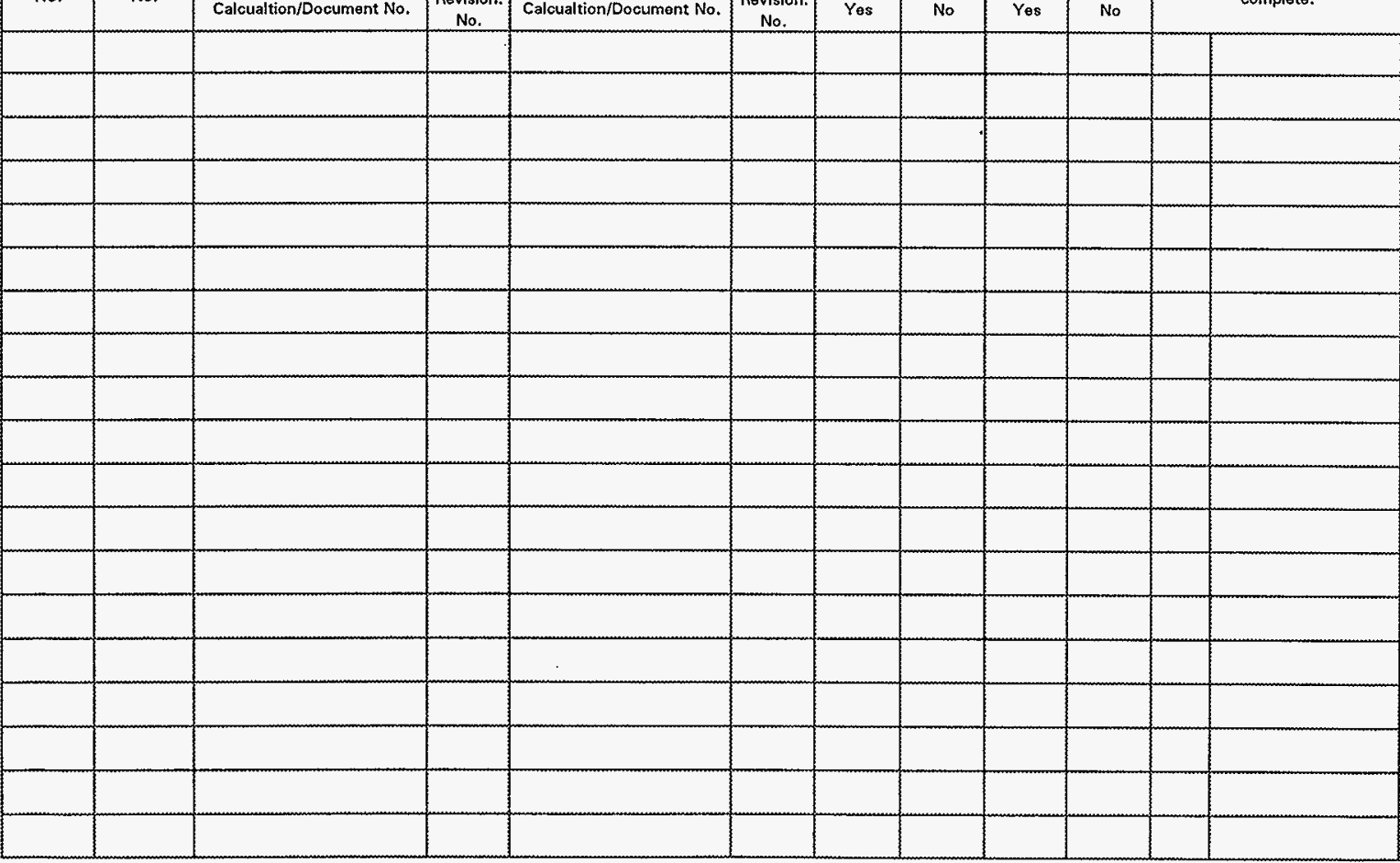


FLUOR DANIEL NORTHWEST

\section{DESIGN ANALYSIS}

Client: NUMATEC HANFORD COMPANY

Subject: SLUICER NOZZLE FORCE ANALYSIS

PROJECT W-320 WASTE RETRIEVAL for TANK 241-C-106

Location: C TANK FARM - HANFORD 200 EAST AREA
Calc. No.: W-320-27-044

Revision No.: 0

Page No.: 1 of 3

Wo/Job No.: W-320/ E09142

Date: $\quad 1 / 7 / 97$

Checked: $01 / 17 / 97$

Revised:
Filename: nozzle.mcd

By: D.L. STONE

By: N.J. JUPLO

By:

\section{OBJECTIVE:}

The objective of this calculation is to calculate the hydraulic forces imposed at the sluicer nozzle.

\section{DESIGN INPUTS:}

1. Project W320, Tank 241-C-106 Sluicing, Functional Design Criteria (WHC document No. WHC-SD-W320-FDC-001, Rev. 2).

2. Project W-320 Drawing \# H-2-818551, Rev. 1

\section{ASSUMPTIONS:}

None

\section{METHOD of ANALYSIS:}

Bernoulli's Momentum equation for steady flow.

Calculations performed by Mathcad 6.0, MathSoft, Inc.

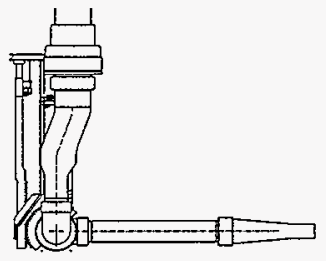

REFERENCES:

1. Project $W 320$, Tank 241-C-106 Sluicing, Functional Design Criteria (WHC document No. WHC-SD-W320-FDC-001, Rev. 2 ).

2. Engineering Fluid Mechanics, J.A. Roberson \& C.T. Crowe, 4th Edition, 1990

3. Crane Technical Paper No. 410, Flow of Fluids Through Pipes, Fittings and Valves, 25th Printing, 1988

4. Project W-320 Drawing \# H-2-818551, Rev.1

5. Project W-320 Drawing \# H-2-818555, Rev.1

\section{DATA:}

Unit Initialization : centipoise $\quad \mathrm{cp}:=0.01$ poise $\quad g=32.174 \cdot \frac{\mathrm{ft}}{\sec ^{2}} \quad \mathrm{gpm}:=\frac{\mathrm{gal}}{\min }$
SG := 1.12
Specific Gravity ( $10 \%$ solids loading)
$\mathrm{Q}:=350 \cdot \mathrm{gpm}$
Flowrate
$\rho_{\mathrm{H} 2 \mathrm{O}}:=62.4 \cdot \frac{\mathrm{lb}}{\mathrm{ft}^{3}} \quad$ Mass Density of Water at Temperature Shown
$\mathrm{d}_{1}:=2.5 \cdot \mathrm{in}$
Bend (Swivel) ID and Nozzle entrance diameter
$d_{2}:=1.00 \cdot$ in
Nozzle exit diameter

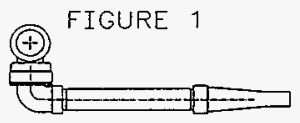

(Ref. 3)

(Ref. 4 \& 5)

(Ref. 1)

(Ref. 1)

(Ref. 4) 
DESIGN ANALYSIS

Client: NUMATEC HANFORD COMPANY Subject: SLUICER NOZZLE FORCE ANALYSIS

PROJECT W-320 WASTE RETRIEVAL for TANK 241-C-106 Location: C TANK FARM - HANFORD 200 EAST AREA
Wo/Job No.: W-320/ E09142

Date: $\quad 1 / 7 / 97$

Checked: o1/17/97

Revised:
Revision No.: 0

Page No: 2 of 3

Fitename: nozzle.med

By: D.L. STONE

By: H.S. JUPLO

By:

\section{CALCULATIONS:}

$\rho:=\mathrm{SG} \cdot \rho_{\mathrm{H} 2 \mathrm{O}}$

$$
p=69.888 \cdot \frac{\mathrm{lb}}{\mathrm{ft}^{3}} \quad \text { Mass Density of Process Fluid }
$$

$\gamma:=\rho \cdot g$

$$
\gamma=69.888 \cdot \frac{\mathrm{lbf}}{\mathrm{ft}^{3}}
$$

Fluid Specific Weight

$\mathrm{A}_{1}:=\frac{\pi \cdot \mathrm{d}_{1}{ }^{2}}{4}$

$\mathrm{A}_{1}=0.034 \cdot \mathrm{ft}^{2}$

Nozzle entrance flow area

$A_{2}:=\frac{\pi \cdot d_{2}{ }^{2}}{4}$

$\mathrm{A}_{2}=0.005 \cdot \mathrm{ft}^{2}$

Nozzle exit flow area

$\mathrm{V}_{1}:=\frac{\mathrm{Q}}{\mathrm{A}_{1}}$

$\mathrm{V}_{1}=22.876 \cdot \frac{\mathrm{ft}}{\mathrm{sec}}$

Nozzle entrance velocity

(Ref. 2, pg. 115)

$\mathrm{V}_{2}:=\frac{\mathrm{Q}}{\mathrm{A}_{2}}$

$\mathrm{V}_{2}=142.974 \cdot \frac{\mathrm{ft}}{\mathrm{sec}}$

Nozzle exit velocity

(Ref. 2, pg. 115)

Energy dissipated by the Nozzle is found from the conservation of mass and energy as applied in the Bernouli Equation:

$$
\begin{aligned}
& \frac{\mathrm{P}_{1}}{\gamma}+\frac{\mathrm{V}_{1}{ }^{2}}{2 \cdot \mathrm{g}}+\mathrm{z}_{1}=\frac{\mathrm{P}_{2}}{\gamma}+\frac{\mathrm{V}_{2}{ }^{2}}{2 \cdot \mathrm{g}}+\mathrm{z}_{2} \\
& \mathrm{~A}_{1} \cdot \mathrm{V}_{1}=\mathrm{A}_{2} \cdot \mathrm{V}_{2}=\mathrm{Q} \\
& \mathrm{z}_{1}=\mathrm{z}_{2} \\
&\left(\frac{\mathrm{P}_{1}-\mathrm{P}_{2}}{\gamma}\right)=\left(\frac{\mathrm{V}_{2}{ }^{2}-\mathrm{V}_{1}{ }^{2}}{2 \cdot \mathrm{g}}\right) \\
& \Delta \mathrm{P}:=\left(\frac{\mathrm{V}_{2}{ }^{2}-\mathrm{V}_{1}{ }^{2}}{2 \cdot \mathrm{g}}\right) \cdot \gamma \quad \Delta \mathrm{P}=150.23 \cdot \mathrm{psi}
\end{aligned}
$$

$$
\text { Since } \quad P_{2}:=0 \cdot p s i \quad \rightarrow \quad P_{1}:=\Delta P-P_{2} \quad P_{1}=150.23 \cdot p s i
$$

Momentum equation for forces on a nozzle

$$
\begin{aligned}
& \sum F=\sum \Delta M \\
& \sum F_{X}=0=F_{\text {nozzle }}+P_{1} \cdot A_{1}-P_{2} \cdot A_{2}, \rho \cdot Q \cdot V_{1}-Q \cdot V_{2}
\end{aligned}
$$

$-F_{\text {nozzle }}:=\rho \cdot Q \cdot\left(V_{1}-V_{2}\right) \stackrel{+}{\&} P_{1} \cdot A_{1}+P_{2} \cdot A_{2} \quad F_{\text {nozzle }}=-930.874 \cdot 1 b f$

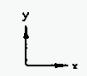

(Ref. 2, pg. 221)

$$
\partial^{2}+10198
$$

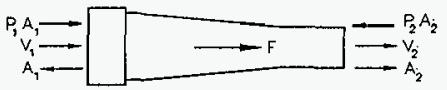


FLUOR DANIEL NORTHWEST

Client: NUMATEC HANFORD COMPANY Subject: SLUICER NOZZLE FORCE ANALYSIS

PROJECT W-320 WASTE RETRIEVAL for TANK 241-C-106 Location: C TANK FARM - HANFORD 200 EAST AREA
WO/Job No: W-320/ E09142

Date: $\quad 1 / 7 / 97$

Checked: $01 / 17 / 97$

Revised:
Calc. No.: W-320-27-044

Revision No.: 0

Page No.: 3 of $\mathbf{3}$

Filename: nozzle.mcd

By: D.L. STONE

By: N.J. JUPLO By:

For $90^{\circ}$ bend:

$$
\begin{aligned}
& A_{1}:=\frac{\pi \cdot d_{1}^{2}}{4} \\
& \mathrm{~A}_{1}=0.034 \cdot \mathrm{ft}^{2} \\
& \text { Bend entrance flow area } \\
& A_{2}:=A_{1} \\
& \mathrm{~A}_{2}=0.034 \cdot \mathrm{ft}^{2} \\
& \text { Bend exit flow area } \\
& V_{1}:=\frac{Q}{A_{1}} \\
& \mathrm{~V}_{1}=22.876 \cdot \frac{\mathrm{ft}}{\mathrm{sec}} \\
& \text { Bend entrance velocity } \\
& \mathrm{V}_{2}:=\frac{\mathrm{Q}}{\mathrm{A}_{2}} \\
& \mathrm{~V}_{2}=22.876 \cdot \frac{\mathrm{ft}}{\mathrm{sec}} \\
& \text { Bend exit velocity } \\
& \mathrm{P}_{2}:=\mathrm{P}_{1} \quad \mathrm{P}_{1}=150.23 \cdot \mathrm{psi} \\
& \Sigma F=\Delta M \\
& F_{\text {bend }}+P_{1} \cdot A_{1}-P_{2} \cdot A_{2}=\rho \cdot V_{1} \cdot\left(V_{1} \cdot A_{1}\right)+\rho \cdot V_{2} \cdot\left(V_{2} \cdot A_{2}\right) \\
& \Sigma F_{X}=0=R_{X}-P_{2} \cdot A_{2} \bar{F} \rho \cdot Q \cdot v_{2}
\end{aligned}
$$

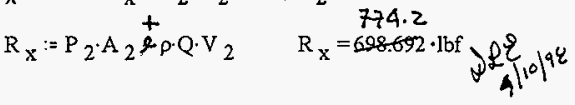

$$
\begin{aligned}
& \Sigma F y=0=-R_{y}-P_{1} \cdot A_{1}-\rho \cdot Q \cdot V_{2} \\
& -R_{y}:=P_{1} \cdot A_{1}+\rho \cdot Q \cdot V_{1} \quad R_{y}=776.19 \cdot 1 b f \\
& 774+(-532) \\
& R_{\text {Total }}:=R_{x}+F_{\text {nozzle }} \\
& \mathrm{R}_{\text {Total }}=\stackrel{+}{+} 242: 181 \cdot \mathrm{lbf}
\end{aligned}
$$

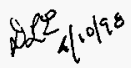$$
\text { (Ref. 5) }
$$

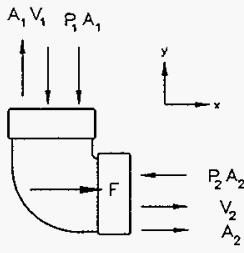

FIGURE 3

\section{CONCLUSION:}

The total force applied at the sluicer nozzle will be $242.181 \mathrm{lbf}$.

ote 
HNF-2477, Rev. 0

W320-27-045

Pipe Drain Flow and Anti-Siphon Sizing for Transfer Lines 
FLUOR DANIEL

NORTHWEST

CALCULATION IDENTIFICATION AND INDEX

Page

This sheet shows the status and description of the attached Design Analysis sheets.

Discipline 27, Piping and vessels WO/Job No. W320/E09141 Calculation No. W320-27-045

Project No. \& Name Project $W-320$ waste Retrieval for Tank 241-C-106

Calculation Item

Pipe Drain Flow and Anti-Siphon Sizing for Transfer Lines

These calculations apply to:

Dwg. No. H-2-818498, Sh. 3, H-2-818531, Sh. 2

Rev. No.

Rev. No.

Dwg. No.

Other (Ștudy, $\overline{\mathrm{CDR}}$ )

Rev. No.

The status of these calculations is:

Preliminary Calculations

冈 Final Calculations

口 Check Calculations (On Calculation Dated

$\square$ Void Calculation (Reason Voided

Incorporated in Final Drawings?

口 Yes $\square$ No

This calculation verified by independent "check" calculation?

口 Yes

No

Original and Revised Calculation Approvals:

\begin{tabular}{|c|c|c|}
\hline & $\begin{array}{l}\text { Rev. } 1 \\
\therefore \text { Signáluie / Date }\end{array}$ & $\begin{array}{c}\text { Rev. } 2 \\
\text { Signature / Date }\end{array}$ \\
\hline \multicolumn{3}{|l|}{ Originator } \\
\hline \multicolumn{3}{|l|}{ Checked by } \\
\hline \multicolumn{3}{|l|}{ Approved by } \\
\hline \multicolumn{3}{|l|}{$\begin{array}{l}\text { Checked Against } \\
\text { Approved Vendor Data }\end{array}$} \\
\hline \multicolumn{3}{|c|}{ INDEX } \\
\hline $\begin{array}{c}\text { Design Analysis } \\
\text { Page No. }\end{array}$ & Description & \\
\hline$i-i i$ & \multicolumn{2}{|l|}{ Calculation Identification and Index } \\
\hline iii & \multicolumn{2}{|l|}{ Calculation Cross Index } \\
\hline 1 & \multicolumn{2}{|c|}{ Objective, Design Inputs, Assumptions, Method of Analysis } \\
\hline $2-3$ & \multicolumn{2}{|l|}{ Method of Analysis, (cont...) } \\
\hline $5-6$ & \multicolumn{2}{|l|}{ Conclusions } \\
\hline $6-7$ & \multicolumn{2}{|c|}{ References } \\
\hline 8 & \multicolumn{2}{|c|}{ Conclusions - Drain Times Summary Spreadsheet } \\
\hline $9-25$ & \multicolumn{2}{|l|}{ Calculations } \\
\hline
\end{tabular}




\begin{tabular}{|l|c|l|l|}
\hline $\begin{array}{l}\text { FLUOR DANIEL } \\
\text { NORTHWEST }\end{array}$ & CALCULATION IDENTIFICATION AND INDEX & Page & ii of iii \\
\cline { 1 - 1 }
\end{tabular}

This sheet shows the status and description of the attached Design Analysis sheets.

\begin{tabular}{|c|c|c|c|}
\hline Discipline & 27, Piping and Vessels & WO/Job No._EO9141. & $W-320-27-045$ \\
\hline & $\begin{array}{c}\text { Rev. 0 } \\
\text { Signature / Date }\end{array}$ & $\begin{array}{c}\text { Rev. } 1 \\
\text { Signature / Date }\end{array}$ & $\begin{array}{c}\text { Rev. } 2 \\
\text { Signature / Date }\end{array}$ \\
\hline Originator & DI. Iexoe 3/25/97 & & \\
\hline Checked by & D.82. Evans 3/25197 & & \\
\hline
\end{tabular}

\begin{tabular}{|c|c|}
\hline $\begin{array}{c}\text { Design Analysis } \\
\text { Page No. }\end{array}$ & Description \\
\hline Appdx A & Calculation of headloss through Pump \\
\hline Appdx B & Calculation of Size of Hole required to Break Siphon \\
\hline Appdx C & Headloss Curve for Micromotion Mass Flow Meter \\
\hline Appdx D & Station Foints \\
\hline Appdx E & PIPE-rLO rodel for Siphoning of 108 Solids Slurry \\
\hline Appdx $F$ & PIPE-FLO Vodel for Draining of 108 Solids Slurry \\
\hline Appdx G & FiEE-FLO Model for Siphoning of $30 \%$ solids slurry \\
\hline Appdx H & PIPE-FLO Wodel for Draining of $30 \%$ Solids Slurry \\
\hline Appdx I & PIPE-FLO idel for Siphoning of 0 of Solids Supernate \\
\hline Appdx J & PIPE-FLO Nodel for Draining of 08 Solids Supernate \\
\hline Appdx $K$ & PIPE-FIO Wuel for Siphoning of 108 Solids Supernate \\
\hline Appdx L & PIEE-ELO Wiel for Draining of 108 Solids Supernate \\
\hline Appdx M & Vendor Datea sheets \\
\hline Appdx N & Prawings \\
\hline
\end{tabular}

\section{INDEX}


CALCULATION CROSS INDÉn (Typica)

Subject Calculation No. W320-27-045

\begin{tabular}{|c|c|c|c|c|c|c|c|c|c|c|c|}
\hline $\begin{array}{c}\text { Subject } \\
\text { Calculation } \\
\text { Revision } \\
\text { No. }\end{array}$ & $\begin{array}{c}\text { Superceded } \\
\text { by } \\
\text { Calculation } \\
\text { No. }\end{array}$ & \multicolumn{2}{|c|}{$\begin{array}{l}\text { These interfacing calculation/documents } \\
\text { provide input to the subject calculation, } \\
\text { and if revised may require revision of } \\
\text { the subject calculation. }\end{array}$} & \multicolumn{2}{|c|}{$\begin{array}{l}\text { Results and conclusions of the subject } \\
\text { calculation are used in these interfacing } \\
\text { calculations and/or documents. }\end{array}$} & \multicolumn{2}{|c|}{$\begin{array}{l}\text { Does the output } \\
\text { interface calculation' } \\
\text { documents require } \\
\text { revision? }\end{array}$} & \multicolumn{2}{|c|}{$\begin{array}{c}\text { Has the output } \\
\text { interface calculation } \\
\text { documents been } \\
\text { revised? }\end{array}$} & \multicolumn{2}{|c|}{$\begin{array}{c}\text { Discipline manager's signature } \\
\text { and date indicating evaluation } \\
\text { complete. }\end{array}$} \\
\hline & & Dwg. H-2-818495, Sh.1 & 1 & & & & $x$ & & $x_{0}$ & 1 & $T$ \\
\hline & & Dwg. H-2-818498, Sh. 3 & 0 & & & & & & & & \\
\hline & & Dwg. H-2-818427, Sh.1 & 0 & & & & 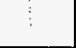 & & & & \\
\hline & & Dwg. H-2-818426, Sh.1 \& 2 & 0 & & & & & & & & \\
\hline & & Dwg. H-2-818508, Sh.1 & 1 & & & & & & & 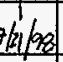 & DLLESamo \\
\hline & & Dwg. H-2-818505, Sh.1 & 1 & & & & & & & $i$ & 1 \\
\hline & & Dwg. H-2-818501, Sh.1 \& 2 & 2 & & & & & & & & \\
\hline & & Dwg. H-2-818501, Sh.1 & 0 & & & & & & & & \\
\hline & & Dwg. H-2-818537, Sh.2 & 1 & & & & & & & & \\
\hline & & Dwg. H-2-818503, Sh.1 & 1 & & & & & & & & \\
\hline & & Dwg. H-2-818515, Sh.1 & 01 & & & & & & 1 & & \\
\hline
\end{tabular}


DESIGN ANALYSIS

Client NUMATEC HANFORD COMPANY

Subject PROJECT W-320 WASTE RETRIEVAL for TANK 241-C-106

Pipe Drainflow and Anti-Siphon Sizing for Transfer Lines

Location

C TANK FARM - MANFORD

200 EAST AREA

Revised

Wo/Job No. E09141

Date $3 / 5 / 97$

Checked $3 / 25 / 97$

Revision No.: 0

Page No. 1 of

\section{OBJECTIVE:}

The objective of this calculation is twofold.

1. To determine if the anti-siphoning holes required to interrupt siphon flow in either the Slurry or Supernate Pipelines are adequately sized.

2. To estimate the time required to drain the lines after termination of flow.

\section{DESIGN INPUTS:}

Project W320, Tank 241-C-106 Sluicing, Functional Design Criteria (WSC document No. WHC-SD-W320-FDC-001, Rev. 4)

\section{ASSUMPTIONS:}

1. The pressure drops across the de-energized pumps were derived for water and adequately model pressure drops for other system fluids.

2. The valve $\mathrm{C} v$ values used were for water and the resulting pressure drops adequately model those for other system fluids .

3. A fluid temperature of $70^{\circ} \mathrm{F}$ has been chosen to conservatively approximate the temperature at which siphoning and line draining would most probably take place.

\section{METHOD OF ANALYSIS:}

Calculations performed using Mathcad 6.0, MathSoft, Inc. are shown with sources noted adjacent to formulas.

Methods used in spreadsheet calculations performed by Microsoft "Excel" Version 5.0 are either summations, or methods and sources are shown on a previous page, using Mathcad 6.0.

Hydraulic calculations are performed by PIPE-FLO, v.5, by Engineered Software, Inc.

The PIPE-FLO program calculates the balanced flow rates and pressures within fluid piping systems using the Darcy-Weisbach equation, which takes into account fluid viscosity and pipe roughness. 


\section{DESIGN ANALYSIS}

Wo/Jab No. E09141

Client NUMATEC HANFORD COMPANY

SUbject PROJECT W-320 WASTE RETRIEVAL for TANK 241-6-106

Pipe Drainflow and Anti-Siphon Sizing for Transfer Lines

Location

C TANK FARM - HANFORD
Date $3 / 5 / 97$

Checked $3 / 25 / 97$

Revised
Calc. No.

W-320-27-045

Revision No: 0

Page No. 2 of 25

\section{Filename siphonltext.mod}

By D.L. STONE $D L 5$

By

D.L. EVANS NE

\section{(METHOD of ANALYSIS, cont...)}

The Darcy-Weisbach equation is as follows: $\Delta P=\rho \cdot f \cdot\left(\frac{L}{D}\right) \cdot \frac{v^{2}}{2 \cdot g} \quad$ where $\quad \Delta P=$ pressure drop

p $\boldsymbol{\square}$ fluid density

f $=$ Darcy friction factor

$L=$ length of pipe

$\mathrm{D}$ = pipe diameter

$\mathrm{v}=$ mean fluid velocity

$\mathrm{g}$ = gravitational constant

For both laminar and non-laminar flow, the friction factor, $f$, is a function of the Reynolds number, calculated by PIPE-FLO using the equation:

$$
\mathrm{R}_{\mathrm{e}}=\frac{354 \cdot \mathrm{W}}{\mu \cdot \mathrm{d}} \quad \text { where } \quad \begin{aligned}
\mathrm{W} & =\text { flow rate, } \mathrm{kg} / \mathrm{hr} \\
\mathrm{d} & =\text { pipe diameter, } \mathrm{mm} \\
H & =\text { fluid dynamic viscosity, centipoise }
\end{aligned}
$$

If PIPE-FLO calculates a Reynolds number less than 2100 , flow is considered to be laminar and the friction factor is expressed using the equation:

$$
\mathrm{f}=\frac{64}{\mathrm{R}_{\mathrm{e}}}
$$

For Reynolds numbers greater than 2100 , flow is considered to be turbulent, and the following equation is used:

$$
f=\frac{1.325}{\left\{\ln \left(\frac{\varepsilon}{3.7 \cdot d}+\frac{5.7}{R_{e}{ }^{0.9}}\right)\right\}^{2}} \quad \varepsilon=\text { ccefficient of absolute roughness for pipe }
$$

PIPE-FLO includes valves and fittings in the calculation using the pipe resistance coefficients (K factors) found in Crane Technical Paper No. 410.

The relationship between the $K$ value and pipe length is: $K=f_{T}\left(\frac{L}{D}\right)$ where $f_{T}=$ turbulent friction factor for which PIPE-FLO uses $\quad f_{T}=8 \cdot\left(2.457 \cdot \ln \left(\frac{3.707 \cdot d}{\varepsilon}\right)\right)^{-2}$ 
DESIGN ANALYSIS

Client NUMATEC HANFORD COMPANY

Subject PROJECT W-320 WASTE RETRIEVAL. for TANK 241-C-106

Pipe Drainflow and Anti-Siphon Sizing for Transfer Lines

Location C TANK FARM - HANFORD 200 EAST AREA
WO/Job No. E09141

Date $3 / 5 / 97$

Checked $5 / 25 / 97$

Revised
Calc. No.

$W-320-27-045$

Revision No:: 0

Page No. 3 of

25

(METHOD of ANALYSIS, cont...)

Calculation of the balanced flow rates in the system is carried out using the Simultaneous Path Adjustment method developed by Don J. Wood of the University of Kentucky. This method uses the Hardy Cross method until the program is close to a solution, then it switches to the linear method to complete the calculations. Information on the Hardy Cross method can be found in Ref 3 . The continuity equations and loop pressure drop equations, based on Kirchoff's Laws 1 and 2, provide the independent equations to perform the linear portion of the calculations.

The PIPE-FLO program requires information about fluid properties in order to analyze a piping system. This calculation includes the hydraulic analysis of both the Slurry Transfer Line, estimated to contain at the time of siphoning, a liquid ranging from $10 \%$ to $30 \%$ solids content, and the Supernate Transfer or "Sluice" Line. containing an estimated $0 \%$ to $10 \%$ solids content. Mass densities and viscosities corresponding to solids content are calculated on page 9 , using relative specific gravities and viscosity adjustment equations specified in the Project Functional Design Criteria (Ref. 1).

Pumps and other components for which headloss varies with flowrate are represented within PIPE-FLO as curves, which have been independently determined and manually input to the program.

Because this calculation addresses only siphoning and drainage scenarios, flow vs.head curves have been developed to account for the headlosses resulting from either forward or reverse flow through the system pumps in non-operational mode. The independent calculation modeling these curves is inclucled as Appendix $A$ of this calculation. Similar curves have been developed to model losses through the Micromotion Mass Flow Meter in the Slurry line, and for the flow monitor located adjacent to the nozzle on the sluice line. The development of these curves is shown on Pages 10 through 14 of this caiculation, using manufacturer's graphs shown in Appendix C. Curves developed for input to PIPE-FLO are summarized in spreadsheet form on page 15.

Standard fittings have been input directly to the system model from a table of standard fittings included in the PIPE-FLO program. Purex connectors are modeled as standard 90 degree miter bends. System valves are considered by PIPE-FLO as specialty valves and have been input to the model using manufacturer-specified $\mathrm{CV}$ values obtained from vendor data (included in Appendix M.)

The Differential Pressure Calculator in PIPE-FLO uses the formula: $K=\frac{891 \cdot d^{4}}{C_{v}{ }^{2}}$ to calculate friction loss coefficient, or $\mathrm{K}$ value, for input to the model.

Input to the system model is described in terms of Node and Pipe names, elevations, dimensions and components in the identification and Configuration section of this calculation on pages 16 through 24 . Although Node points are normally determined by pipe diameter changes, Nodes have been included at the following additional locations in order to facilitate the objectives of this analysis. 
Client NUMATEC HANFORD COMPANY

Subject PROJECT W-320 WASTE RETRIEVAL for TANK 241-C-106

Pipe Drainflow and Anti-Siphon Sizing for Transfer Lines

Location C TANK FARM - HANFORD 200 EAST AREA
WO/Job No. E09141

Date $3 / 5 / 97$

Checked $3 / 25 / 97$

Revised
Filename siphonltext.mod

BY D.L. STONE DLS

By

By

(METHOD of ANALYSIS, cont..)

1. Nodes have been placed at the locations of holes drilled in the pipe to provide the inlet of air to prevent siphoning.

2. Nodes have been placed at elevations corresponding to transfer line station points identified in the project profile drawings included in Appendix D.

\section{Pipe Draining}

The times required to drain the Slurry and Sluice pipelines have been determined using flow results from the PIPE-FLO program. Pipe drain flows were derived by modeling simulated reservoirs at the pipe high point and at an elevation representing the top of the lower third of the transfer line. The PIPE-FLO models were then run to determine the steady state pipe flows for fluids at various \% solids and are included as Appendices $F, H, J \& L$. These drain flows were then used to determine:

a) The time to void the top $2 / 3$ of the pipe, by using the average steady state drain flow from the two reservoirs.

b) The time to void the lower third, by using the drain flow from the lower reservoir.

The respective pipe flows and times required to drain the pipes are listed in the conclusion section.

\section{Siphon Flows}

Siphon flows have been determined using the PIPE-FLO program, and models included in Appendices $E, G, I \& K$. Flows were derived by modelling reservoirs at locations that maximize the hydraulic head available to drive the siphon. The reservoirs were placed as follows:

Slurry Line: The top reservoir located at the AY-102's maximum liquid level. The lower reservoir located at the lowest liquid level for C-106.

Supernate Line: The top reservoir located at the AY-102's maximum liquid level. The lower reservoir located at the lowest level of the sluice nozzle in C-106.

The siphon models were run to determine steady state flows. Since PIPE-FLO does not provide for two-phase flow analysis, the models did not include openings at the locations of the holes drilled in the pipe to provide the inlet of air to prevent siphoning.

Nodes have been assigned at the locations of these holes and the corresponding siphon flows and fluid pressures are listed in the conclusion section of the calculation. 


\section{DESIGN ANALYSIS}

Client

Pipe Drainflow and Anti-Siphon Sizing for Transfer Lines

Location CTANK FARM - HANFORD 200 EAST AREA
WO/Job No. E09141

Date $\quad 3 / 5 / 97$

Checked $3 / 25 / 97$

Revised
Calc. No.

W-320-27-045

Revision No: 0

Page No. 5 of 25

Filename siphonitext.med

By D.L. STONE $D / S$

By

By

\section{CONCLUSIONS}

The following results are taken from the Summary Table (Page 8) and Air Flow calculations, Appendix B.

\begin{tabular}{|c|c|c|c|c|c|c|c|c|c|}
\hline & $\begin{array}{l}\text { Drain } \\
\text { Time } \\
\text { (min) }\end{array}$ & $\begin{array}{l}\text { Drain } \\
\text { Flow } \\
\text { (gpm) }\end{array}$ & $\begin{array}{l}\text { Drain } \\
\text { Flow } \\
\text { (ACFM) }\end{array}$ & $\begin{array}{l}\text { Siphon } \\
\text { Flow } \\
\text { (gpm) }\end{array}$ & $\begin{array}{l}\text { Siphon } \\
\text { Flow } \\
\text { (ACFM) }\end{array}$ & $\begin{array}{l}\text { Fluid Pressure } \\
\text { at Hole Elev. } \\
\text { (psig) }\end{array}$ & $\begin{array}{c}\text { Anti-Siphon } \\
\text { Air Flow } \\
\text { (SCFM) }\end{array}$ & $\begin{array}{l}n \text { Hole } \\
\text { Then } \\
\text { nole } \\
\text { sach }\end{array}$ & $\begin{array}{l}1 \text { open } \\
\text { of } z \text { on } \\
\text { lime }\end{array}$ \\
\hline \multicolumn{10}{|l|}{ Slurry Line } \\
\hline $10 \%$ Solids & 7.88 & 150.9 & 20.17 & 112 & 14.97 & $(-) 6.159$ & 49.33 & & \\
\hline $30 \%$ Solids & 8.75 & 141.5 & 18.92 & 81.03 & 10.83 & (-) 6.656 & 49.54 & & \\
\hline \multicolumn{10}{|l|}{ Sluice Line } \\
\hline $0 \%$ Solids & 12.35 & 86.78 & 11.6 & 75.41 & 10.08 & (-) 3.917 & 11.23 & & \\
\hline $10 \%$ Solids & 12.73 & 84.96 & 12.43 & 71.98 & 9.62 & (-) 4.368 & 11.58 & & \\
\hline
\end{tabular}

\section{Drain Times}

From the above table the slurry line will free drain in $7.88 \mathrm{~min}$ to $8.75 \mathrm{~min}$ depending on solids content. The sluice line will free drain in $12.35 \mathrm{~min}$ to $12.73 \mathrm{~min}$ depending on solids content.

\section{Hole sizing for Siphon Prevention}

Slurry Line

The slurry line normally flows from $\mathrm{C}-106$ to $\mathrm{AY}-102$ and contains two 1/2" diameter holes located approximately 12' above the AY-102 maximum tank liquid level. When power is removed from the pumps, flow will slow, reverse itself, and begin siphoning from AY-102. The siphon may be broken before the siphon flow derived by the model is attained. From the model, maximum stable siphon flow is 112 $\mathrm{gpm}(14.97 \mathrm{cfm})$ with a $(-) 6.159 \mathrm{psig}$ fluid pressure at the elevation of the anti-siphon holes. With a (-) $6.159 \mathrm{psig}$, across the holes, the line will aspirate $49.33 \mathrm{cfm}$ of air, from Appendix B. This volume of air will displace all forward flowing fluid and allow the column of fluid in the leg from the tank to settle to some equilibrium level below the holes. The siphon will be broken. The maximum air flow required to support free draining is $14.97 \mathrm{cfm}$. From Appendix B, $14.97 \mathrm{cfm}$ of air requires a pressure drop of 0.315 psig across the $1 / 2 "$ anti-siphon holes. 
DESIGN ANALYSIS

Client NUMATEC HANFORD COMPANY
Subject PROJECT W-320 WASTE RETRIEVAL for TANK 247-c-106
Pipe Drainflow and Anti-Siphon Sizing for Transfer Lines
Location C TANK FARM - HANFORD 200 EAST AREA

Calc. No.

$W-320-27-045$

Revision No:: 0

Page No. 6 of

WO/Job No. E09141

Date $\quad 3 / 5 / 97$

Checked $3 / 25197$

Revised
Filename siphonltext.mcd

By D.L. STONE D S

By D.L. EVANS NEE

Sluice Line

The siuice line normally flows from $A Y-102$ to $C-106$ and contains two $1 / 4$ " diameter anti-siphon holes located approximately $8^{\circ}$ above the AY-102 maximum tank liquid level. When power is removed from the pumps, flow will slow and decay to the modelled siphon rate from AY-102. The siphon may be broken before the flow derived by the model is attained. From the model, maximum stable siphon flow is 75.41 $\mathrm{gpm}(10.08 \mathrm{cfm})$ with a (-) $3.917 \mathrm{psig}$ fluid pressure at the drilled hole location. With a (-) $3.917 \mathrm{psig}$, across the holes, the line will aspirate $11.23 \mathrm{cfm}$ of air, from Appendix B. This volume of air will displace all forward flowing fluid and allow the column of fluid in the leg from the tank to settle to some equilibrium level. The siphon will be broken. The maximum air flow required to support free draining is $10.08 \mathrm{cfm}$. From Appendix B, $10.08 \mathrm{cfm}$ of air requires a pressure drop of $2.83 \mathrm{psig}$ across the $1 / 4$ " anti-siphon holes.

The $1 / 4^{\prime \prime}$ and $1 / 2$ " holes are of sufficient size to break the siphon flows and support free draining of the slurry and sluice lines.

\section{REFERENCES}

1. Project W320, Tank 241-C-106 Sluicing. Functional Design Criteria (WSC document No. WHC-SD-W320-FDC-001, Rev. 4)

2. Centrifugal and Axial Flow Pumps, A.J. Stepanoff, 2nd Edition, 1957

3. Fluid Mechanics, Victor L. Streeter

4. Engineering Fluid Mechanics, J.A. Roberson \& C.T. Crowe, 4th Edition, 1990

5. Process Heat Transfer, McGraw-Hill, D.Q.Kern, 1990.

6. Crane Technical Paper No. 410. Flow of Fluids Through Pipes, Fittings and Valves, 25th Printing, 1988

7. TUBE TURN Welding Fittings and Flanges, Catalog 311, 1954

8. PBM Reference Book, Section II SP Series, 1992 PBM, Inc. Rev 2/92 -LT-8D

9. PBM Reference Book, Section IV MP Series, 1992 PBM, Inc. Rev 2/92 -LT-8D

10. Control Valve Handbook, Fisher Controls Company

11. T-M Swivel Joint Catalog.

12. "Mathcad" Version 6.0, MathSoft, Inc.

13. "Excel" Version 5.0, by Microsoft

14. "PIPE-FLO" Version 5.0, by Engineered Software, Inc. 
DESIGN ANALYSIS

Client NUMATEC HANFORD COMPANY

Subject PROJECT W-320 WASTE RETRIEVAL for TANK 241-C-106

Pipe Drainflow and Anti-Siphon Sizing for Transfer Lines

Location C TANK FARM - HANFORD 200 EAST AREA
WO/Job No. E09141

Date $\quad 3 / 5 / 97$

Checked $3 / 25197$

Revised
Calc. No.

W-320-27-045

Revision No.: 0

Page No. 7 of 25

\section{(REFERENCES, cont...)}

\section{Project $W-320$ Drawings:}

General: $\quad 15.0 \mathrm{H}-2-818495$, Sh. 1 Pump and Winch Assembly

$15.1 \mathrm{H}-2-818536$, Sh. 1 Hydraulic Diagram

$15.2 \mathrm{H}-2-818498$, Sh. 2 Shielding Plate

$15.3 \mathrm{H}-2-818498$, Sh. 3 Shielding Plate

$15.4 \mathrm{H}-2-818427$, Sh. 1 Transfer System Plan and Profile

$15.5 \mathrm{H}-2-818426$, Sh. 1 Transfer System Plan and Profile

$15.6 \mathrm{H}-2-818426$, Sh. 2 Transfer System Plan and Profile

$15.7 \mathrm{H}-2-818434$, Sh. 1 Transfer System Plan and Profile

Slurry Line: $\quad 15.8$ H-2-818494, Sh. 1 Pump and Winch Installation - C-Tank

$15.9 \mathrm{H}-2-818508$, Sh. 1 Jumper Assembly Pit C-06A (Pump Jumper)

$15.10 \mathrm{H}-2-818505$, Sh. 1 Jumper Assembly Pit C-06A (Jumper)

$15.11 \mathrm{H}-2-818501$, Sh. 1 Jumper Assembly Pit C-02A (Distributor Jumper)

15.12 H-2-818501, Sh. 2 Jumper Assembly Pit C-02A (Distributor Jumper)

$15.13 \mathrm{H}-2-818537, \mathrm{Sh} .1$ Distributor Assembly

15.14 H-2-818537, Sh. 2 Distributor Assembly

Supernate Line: $\quad 15.15$ H-2-818494, Sh. 2 Pump and Winch Installation-AY-Tank

$15.16 \mathrm{H}-2-818503$, Sh. 1 Jumper Assembly Sluice Pit AY-O2E (Pump Jumper)

$15.17 \mathrm{H}-2-818515$, Sh. 1 Jumper Assembly Sluice Pit C-06C (Sluicer Jumper)

$15.18 \mathrm{H}-2-81855\}$, Sh. 2 Sluicer Assembly Details (Swivel)

15.19 H-2-818551, Sh. 4 Piping Sluicer Assembly Feedplate

15.20 H-2-818551, Sh. 7 Sluicer Assembly Details (Nozzle)

$15.21 \mathrm{H}-2-818549$, Sh. 1 Sluicer Installation 


\section{NORTHWEST}

DESIGN ANALYSIS

Client NUMATEC HANFORD COMPANY

SUbject PROJECT W-320 WASTE RETRIEVAL for TANK 241-C.106 PIPE DRAINFLOW and ANTI-SIPHON SIZING FOR TRANSFER LINES Location C TANK FARM 200 EAST AREA
Caic. No.

W-320-27-045

Revision No. 0

Page No. 8 of 25

WO/Job No. E09141 Filename draintime.xls

Date 3/5/1997 By D. L. STONE $\mathcal{D} L 5$ Checked 3125197 By D. L. EVANS\&28

SUMMARY OF DRAIN TIMES $\quad$ (For calculation details, see Page 25)

\begin{tabular}{|c|c|c|c|c|c|c|c|c|c|}
\hline $\begin{array}{c}\text { Pipe } \\
\# \\
\end{array}$ & $\begin{array}{c}\text { Pipe ID } \\
\quad \text { (in) } \\
\end{array}$ & $\begin{array}{l}\text { Area } \\
\left(\text { (in }^{\wedge} 2\right) \\
\end{array}$ & $\begin{array}{l}\text { Length } \\
\text { (ft) }\end{array}$ & $\begin{array}{r}\text { Volume } \\
\text { (gal) } \\
\end{array}$ & $\begin{array}{c}\text { Volume } \\
\left(\mathrm{f}^{\wedge} 3\right)\end{array}$ & $\begin{array}{l}\text { Drainflow } \\
\text { Highoint to } \\
\text { End } \\
\text { (gpm) }\end{array}$ & $\begin{array}{c}\text { Drainflow } \\
\text { Lowpoint } \\
\text { to End } \\
\text { (gpm) }\end{array}$ & $\begin{array}{l}\text { Average } \\
\text { Drainflow } \\
\text { ( } \mathrm{f}^{\wedge} 3 / \mathrm{min} \text { ) }\end{array}$ & $\begin{array}{c}\text { Average } \\
\text { Time to } \\
\text { Drain } \\
\text { (min) }\end{array}$ \\
\hline \multicolumn{2}{|c|}{ Slurry Line } & \multicolumn{8}{|c|}{$10 \%$ Solids } \\
\hline 3.3 & 4.03 & 12.73 & 843.20 & 557.58 & 74.54 & 146.7 & 150.9 & 19.89 & 3.75 \\
\hline 3.2 & 4.03 & 12.73 & 468.10 & 309.54 & 41.38 & $\{46.7$ & 150.9 & 19.89 & 2.08 \\
\hline 3.1 & 4.03 & .12 .73 & 427.61 & 282.76 & 37.80 & & 150.9 & 20.17 & 1.87 \\
\hline 3 & 3.07 & 7.39 & 4.767 & 1.83 & 0.24 & & 150.9 & 20.17 & 0.012 \\
\hline 2.1 & 4.03 & 12.73 & 1.0 & 0.66 & 0.09 & & 150.9 & 20.17 & 0.004 \\
\hline 2 & 4.03 & 12.73 & 34.86 & 23.05 & 3.08 & & 150.9 & 20.17 & 0.153 \\
\hline 1 & 3.07 & 7.39 & 2.32 & 0.89 & 0.12 & & 150.9 & 20.17 & 0.006 \\
\hline 0 & 5.05 & 20.01 & 0.442 & 0.46 & 0.06 & & 150.9 & 20.17 & 0.003 \\
\hline
\end{tabular}

Slurry Line $\quad 30 \%$ Solids

\begin{tabular}{|c|c|c|c|c|c|c|c|c|c|}
\hline 3.3 & 4.03 & 12.73 & 843.20 & 557.58 & 74.54 & 122.7 & 141.5 & 17.66 & 4.22 \\
3.2 & 4.03 & 12.73 & 468.10 & 309.54 & 41.38 & 122.7 & 141.5 & 17.66 & 2.34 \\
3.1 & 4.03 & 12.73 & 427.61 & 282.76 & 37.80 & & 141.5 & 18.92 & 2.00 \\
3 & 3.07 & 7.39 & 4.767 & 1.83 & 0.24 & & 141.5 & 18.92 & 0.013 \\
2.1 & 4.03 & 12.73 & 1.0 & 0.66 & 0.09 & & 141.5 & 18.92 & 0.005 \\
2 & 4.03 & 12.73 & 34.86 & 23.05 & 3.08 & & 141.5 & 18.92 & 0.163 \\
1 & 3.07 & 7.39 & 2.32 & 0.89 & 0.12 & & 141.5 & 18.92 & 0.006 \\
0 & 5.05 & 20.01 & 0.442 & 0.46 & 0.06 & & 141.5 & 18.92 & 0.003 \\
\hline
\end{tabular}

Time to Drain in minutes :

8.75

Sluicer Line $\quad 0 \%$ Solids

\begin{tabular}{|c|c|c|c|c|c|c|c|c|c|}
\hline 4.1 & 4.03 & 12.73 & 822.80 & 544.09 & 72.73 & 105.6 & 86.78 & 12.86 & 5.66 \\
4.2 & 4.03 & 12.73 & 468.10 & 309.54 & 41.38 & 105.6 & 86.78 & 12.86 & 3.22 \\
4.3 & 4.03 & 12.73 & 428.70 & 283.48 & 37.90 & & 86.78 & 11.60 & 3.27 \\
4.4 & 4.03 & 12.73 & 26.27 & 17.37 & 2.32 & & 86.78 & 11.60 & 0.200 \\
5 & 2.47 & 4.79 & 1.231 & 0.31 & 0.04 & & 86.78 & 11.60 & 0.004 \\
6 & 2.07 & 3.36 & 0.667 & 0.12 & 0.02 & & 86.78 & 11.60 & 0.001 \\
7 & 2.47 & 4.79 & 1.203 & 0.30 & 0.04 & & 86.78 & 11.60 & 0.003 \\
8 & 2.47 & 4.79 & 0.604 & 0.15 & 0.02 & & 86.78 & 11.60 & 0.002 \\
9 & 0.96 & 0.72 & 0.271 & 0.01 & 0.00 & & 86.78 & 11.60 & 0.000 \\
\hline
\end{tabular}

$1749.8 \quad$ Time to Drain in minutes : $\quad 12.35$

Sluicer Line
\begin{tabular}{|c|c|c|c|c|c|c|c|c|c|}
\hline 4.1 & 4.03 & 12.73 & 822.80 & 544.09 & 72.73 & 101 & 84.96 & 12.43 & 5.85 \\
4.2 & 4.03 & 12.73 & 468.10 & 309.54 & 41.38 & 101 & 84.96 & 12.43 & 3.33 \\
4.3 & 4.03 & 12.73 & 428.70 & 283.48 & 37.90 & & 84.96 & 11.36 & 3.34 \\
4.4 & 4.03 & 12.73 & 26.27 & 17.37 & 2.32 & & 84.96 & 11.36 & 0.204 \\
5 & 2.47 & 4.79 & 1.231 & 0.31 & 0.04 & & 84.96 & 11.36 & 0.004 \\
6 & 2.07 & 3.36 & 0.667 & 0.12 & 0.02 & & 84.96 & 11.36 & 0.001 \\
7 & 2.47 & 4.79 & 1.203 & 0.30 & 0.04 & & 84.96 & 11.36 & 0.004 \\
8 & 2.47 & 4.79 & 0.604 & 0.15 & 0.02 & & 84.96 & 11.36 & 0.002 \\
9 & 0.96 & 0.72 & 0.271 & 0.01 & 0.00 & & 84.96 & 11.36 & 0.000 \\
\hline
\end{tabular}

Time to Drain in minutes :

12.73 


\section{DESIGN ANALYSIS}

WO/Job No. E09141

Client NUMATEC HANFORD COMPANY

Subject PROJECT W-320 WASTE RETRIEVAL for TANK 241-C-106

Pipe Drainflow and Anti-Siphon Sizing for Transfer Lines

Location C TANK FARM - HANFORD 200 EAST AREA
Date $3 / 5 / 97$

Checked $3 / 25 / 97$

Revised
Calc. No. W-320-27-045

Revision No: 0

Page No. 9 of 25

Filename viscosty.med

By D.L. STONE DLS

By D.L. EVANS \&L

\section{Caiculation of Mass Density and Dynamic Viscosity based on Percent Solids}

$\mathrm{T}:=70 \cdot \mathrm{F}$

$\rho_{\mathrm{H} 2 \mathrm{O}}:=62.305 \cdot \frac{\mathrm{lb}}{\mathrm{ft}^{3}}$

$\mu_{\mathrm{T}}=\mu_{\%} \cdot(1-0.005 \cdot(T-68))$
Operating Temperature

Water Density at Temperature Shown

Temperature adjustment equation from FDC
(See Assumption 2)

$$
\begin{array}{lllll}
S G:=1.0 & \text { Specific Gravity } & (0 \% \text { solids loading) (Water) } & \text { (Ref. 1) } \\
\rho:=S G \cdot \rho \text { H2O } & \rho=62.305 \cdot \frac{1 \mathrm{~b}}{\mathrm{ft}^{3}} & \text { Process Fluid Density } \\
\mu_{0 \%}:=4 \cdot \mathrm{cp} & \text { Viscosity at } 68 \text { degrees } \mathrm{F} & (0 \% \text { solids loading })
\end{array}
$$

$\mu_{0 \% 70}:=\mu_{0 \%}(1-0.005 \cdot(70-68)) \quad \mu_{0 \% 70}=3.96 \cdot \mathrm{cp} \quad$ Viscosity at $0 \%$ Solids, 70 degrees $F$

$$
\begin{aligned}
& \mathrm{SG}:=1.12 \\
& \text { Specific Gravity } \\
& \text { ( } 10 \% \text { solids loading) } \\
& \mu_{10 \%}:=13 \cdot \mathrm{cp} \quad \text { Viscosity at } 68 \text { degrees } F
\end{aligned}
$$

$$
\begin{aligned}
& \mathrm{SG}:=1.2 \\
& \text { Specific Gravity } \\
& \text { ( } 30 \% \text { solids loading) } \\
& \rho:=S G \cdot \rho_{\mathrm{H} 2 \mathrm{O}} \quad \rho=74.766 \cdot \frac{\mathrm{lb}}{\mathrm{ft}^{3}} \quad \text { Process Fluid Density } \\
& \mu_{30 \%}:=105 \cdot \mathrm{cp} \quad \text { Viscosity at } 68 \text { degrees } F \\
& \left.\mu_{30 \% 70}:=\mu_{30 \%} \cdot(1-0.005 \cdot(70-68)) \quad \mu_{30 \% 70}=103.95 \cdot \mathrm{cp} \quad \text { Viscosity at } 0 \% \text { Solids, } 70 \text { degrees } F \quad \text { (Ref. } 1\right)
\end{aligned}
$$


FLUOR DANIEL

NORTHWEST

\section{DESIGN ANALYSIS}

Client NUMATEC HANFORD COMPANY

Subject PROJECT W-320 WASTE RETRIEVAL for TANK 241-C-106

Pipe Drainflow and Anti-Siphon Sizing for Transfer Lines Location C TANK FARM - HANFORD 200 EAST AREA
WO/Job No. E09141

Date $\quad 3 / 5 / 97$

Checked $3 / 2519=$

Revised
Calc. No.

Revision No: 0

Page No. 10 of 25

Filename micromtn.med

BY D.L. STONE $D<S$

By D.L. EVANS 8 By

Calculation of Flow vs Head Curve for Micromotion Mass Flowmeter

(For Vendor Data, see Appendix M)

$\mathrm{SG}:=1.12$

Specific Gravity for $10 \%$ Solids at $70^{\circ} \mathrm{F}$

$\rho:=S G \cdot \rho$ H2O $\quad \rho=69.782 \cdot \frac{\mathrm{lb}}{\mathrm{ft}^{3}} \quad$ Process Fluid Density

(Ref. Pg. 7)

$\gamma:=\rho \cdot g \quad \gamma=69.782 \cdot \frac{\mathrm{lbf}}{\mathrm{f}^{3}} \quad$ Specific weight of fluid.

$\mu:=12.87 \cdot \mathrm{cp}$

Viscosity at $10 \%$ solids

(Ref. Pg. 7)

Volumetric Flowrate

$\mathrm{Q}_{50}:=50 \cdot \frac{\mathrm{gal}}{\mathrm{min}}$

$Q_{150}:=150 \cdot \frac{\mathrm{gal}}{\mathrm{min}}$

$\mathrm{Q}_{250}:=250 \cdot \frac{\mathrm{gal}}{\mathrm{min}}$

$Q_{350}:=350 \cdot \frac{\mathrm{gal}}{\mathrm{min}}$

Mass Flowrate corresponding to Micromotion graph
$\mathrm{m}_{\mathrm{q} 50}:=\mathrm{Q}_{50} \cdot \mathrm{\rho}$
$\mathrm{m}_{\mathrm{q} 150}:=\mathrm{Q}_{150^{\circ} \mathrm{\rho}}$
$\mathrm{m}_{\mathrm{q} 250}:=\mathrm{Q}_{250} \rho$
$\mathrm{m}_{\mathrm{q} 350}:=\mathrm{Q}_{350^{\circ}} \mathrm{P}$
$\mathrm{m}_{\mathrm{q} 50}=466.422 \cdot \frac{\mathrm{lb}}{\min }$
$\mathrm{m}_{\mathrm{q} 150}=1.399 \cdot 10^{3} \cdot \frac{\mathrm{lb}}{\mathrm{min}}$
$\mathrm{m}_{\mathrm{q} 250}=2.332 \cdot 10^{3} \cdot \frac{\mathrm{lb}}{\mathrm{min}}$
$\mathrm{m}_{\mathrm{q} 350}=3.265 \cdot 10^{3} \cdot \frac{\mathrm{lb}}{\mathrm{min}}$

Pressure Drop corresponding to Micromotion graph
$\mathrm{P}_{50}:=.34 \cdot \mathrm{psi}$
$\mathrm{P}_{150}:=1.8 \cdot \mathrm{psi}$
$P_{250}:=4.5 \cdot p s i$
$\mathrm{P}_{350}:=8.3 \cdot \mathrm{psi} \quad$ (Ref. Appendix C)
$\mathrm{h}_{50}:=\frac{\mathrm{P}_{50}}{\gamma}$
$h_{150}:=\frac{P_{150}}{\gamma}$
$h_{250}:=\frac{P_{250}}{\gamma}$
$h_{350}:=\frac{P_{350}}{\gamma}$
$\mathrm{h}_{50}=0.702 \cdot \mathrm{ft}$
$h_{150}=3.714 \cdot \mathrm{ft}$
$h_{250}=9.286 \cdot f t$
$h_{350}=17.128 \cdot f t$ 
DESIGN ANALYSIS

Client NUMATEC HANFORD COMPANY

Subject PROJECT W-320 WASTE RETRIEVAL for TANK 241-C-106

Pipe Drainflow and Anti-Siphon Sizing for Transfer Lines

Location C TANK FARM - HANFORD 200 EAST AREA
WO/Job No. E09141

Date $3 / 5 / 97$

Checked $3 / 25 / 97$

Revised
Calc. No.

W-320-27-045

Revision No: 0

Page No. 11 of 25

Filename micromtn.med

BY D.L. STONE DCS

By D.L. EVANS $\$ \& E$

By

Calculation of Flow vs Head Curve for Micromotion Mass Flowmeter

SG $:=1.2$

Specific Gravity for $30 \%$ Solids at $70^{\circ} \mathrm{F}$

$\rho:=\mathrm{SG} \cdot \rho_{\mathrm{H} 2 \mathrm{O}} \quad \rho=74.766 \cdot \frac{\mathrm{lb}}{\mathrm{ft}^{3}} \quad$ Process Fluid Density

(Ref. Pg. 7)

$\gamma:=\rho \cdot g \quad \gamma=74.766 \cdot \frac{\mathrm{lbf}}{\mathrm{ft}^{3}} \quad$ Specific weight of fluid.

$\mu:=103.95 \cdot \mathrm{cp}$

Volumetric Flowrate

$\mathrm{Q}_{50}:=50 \cdot \frac{\mathrm{gal}}{\mathrm{min}} \quad \mathrm{Q}_{150}:=150 \cdot \frac{\mathrm{gal}}{\mathrm{min}} \quad \mathrm{Q}_{250}:=250 \cdot \frac{\mathrm{gal}}{\mathrm{min}} \quad \mathrm{Q}_{350}:=350 \cdot \frac{\mathrm{gal}}{\mathrm{min}}$

Mass Flowrate corresponding to Micromotion graph
$\mathrm{m}_{\mathrm{q} 50}:=\mathrm{Q}_{50} \cdot \mathrm{p}$
$\mathrm{m}_{\mathrm{q} 150}:=\mathrm{Q}_{150} \cdot \mathrm{\rho}$
$\mathrm{m}_{\mathrm{q} 250}: \mathrm{Q}_{250^{\circ} \mathrm{P}}$
$\mathrm{m}_{\mathrm{q} 350}:=\mathrm{Q}_{350^{\circ} \rho}$
$m_{q 50}=499.738 \cdot \frac{\mathrm{lb}}{\mathrm{min}}$
$\mathrm{m}_{\mathrm{q} 150}=1.499 \cdot 10^{3} \cdot \frac{\mathrm{lb}}{\mathrm{min}}$
$\mathrm{m}_{\mathrm{q} 250}=2.499 \cdot 10^{3} \cdot \frac{\mathrm{lb}}{\mathrm{min}}$
$m_{\mathrm{q} 350}=3.498 \cdot 10^{3} \cdot \frac{\mathrm{lb}}{\mathrm{min}}$

Pressure Drop corresponding to Micromotion graph
$\mathrm{P}_{50}:=1.2 \cdot \mathrm{psi}$
$\mathrm{P}_{150}:=4 \cdot \mathrm{psi}$
$P_{250}:=10 \cdot p s i$
$P_{350}:=17.5 \cdot p s i$
(Ref. Appendix C)
$\mathrm{h}_{50}:=\frac{\mathrm{P}_{50}}{\gamma}$
$\mathrm{h}_{150}:=\frac{\mathrm{P}_{150}}{\gamma}$
$\mathrm{h}_{250}:=\frac{\mathrm{P}_{250}}{\gamma}$
$\mathrm{h}_{350}:=\frac{\mathrm{P}_{350}}{\gamma}$
$\mathrm{h}_{50}=2.311 \cdot \mathrm{ft}$
$h_{150}=7.704 \cdot f t$
$h_{250}=19.26 \cdot f t$
$\mathrm{h}_{350}=33.705 \cdot \mathrm{ft}$ 
FLUOR DANIEL NORTHWEST

DESIGN ANALYSIS

Client NUMATEC HANFORD COMPANY

Subject PROJECT W-320 WASTE RETRIEVAL for TANK 241-C-106

Pipe Drainflow and Anti-Siphon Sizing for Transfer Lines

Location

C TANK FARM - HANFORD

200 EAST AREA
Calc. No.

Revision No: 0

Page No. 12 of 25

WO/sob No. E09141

Date $3 / 5 / 97$

Checked 3/25197

Revised
Filename monitor.mcd

BY D.L. STONE DLS

By D.L. EVANS $2 \mathcal{L}$

\section{Calculation of Headloss Curves for 18" Supernate Line Monitor Tube:}

Given / Known Data:

$\mathrm{d}:=2.469 \cdot \mathrm{in}$

$A:=\frac{\pi \cdot d^{2}}{4}$

$L_{\text {yein }}:=1 \cdot$ in

$P_{w}:=(\pi \cdot d)+4 \cdot\left(2 \cdot L_{\text {vein }}\right)$

$P_{W}=15.757 \cdot$ in

$A:=\left(\frac{\pi \cdot d^{2}}{4}\right)-4 \cdot\left[(1 \cdot\right.$ in $) \cdot\left(\frac{1}{8} \cdot\right.$ in $\left.)\right]$

$\mathrm{A}=4.288 \cdot \mathrm{in}^{2}$

$\mathrm{D}_{\mathrm{e}}:=\frac{4 \cdot \mathrm{A}}{\mathrm{P}_{\mathrm{w}}}$

$\mathrm{D}_{\mathrm{e}}=1.088 \cdot \mathrm{in}$

Entrance Pipe Inner Diameter

Entrance Pipe Flow Area:

Length of Monitor tube veins

Wetted Perimeter of Piping

Flow Area inside Monitor Tube

$Q_{i}:=$

350.GPM

$250 \cdot \mathrm{GPM}$

150.GPM

$50 \cdot \mathrm{GPM}$

.01-GPM
Flow Rate

$$
v_{i}:=\frac{Q_{i}}{A}
$$

$$
v=\left[\begin{array}{l}
0 \\
26.189 \\
18.706 \\
11.224 \\
3.741 \\
7.483 \cdot 10^{-4}
\end{array}\right] \cdot \frac{\mathrm{ft}}{\mathrm{sec}} \text { Velocity }
$$

(Ref. 15.7, Sh.7)

Ref. 5, Pg.105

Monitor Tube Losses at $10 \%$ Solids Loading:

$$
\begin{aligned}
& S G:=1.12 \\
& \text { Specific Gravity ( } 10 \% \text {, solids loading) } \\
& \rho_{\mathrm{H} 2 \mathrm{O}}:=62.305 \cdot \frac{\mathrm{lb}}{\mathrm{ft}^{3}} \\
& \text { Water Density at } 70^{\circ} \mathrm{F} \\
& \rho:=S G \cdot \rho \text { H2O } \rho=69.782 \cdot \frac{\mathrm{lb}}{\mathrm{ft}^{3}} \text {. } \\
& \text { Process Fluid Density } \\
& \mu_{10 \%}:=13 \\
& \text { Viscosity for } 10 \% \text { solids fluid at } 68 \text { degrees } F \\
& \mu_{10 \% 70}:=\mu_{10 \%} \cdot(1-0.005 \cdot(70-68)) \quad \text { Temperature adjustment equation from FDC }
\end{aligned}
$$

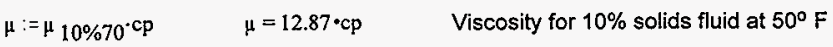

(Ref. 1)

(Ref. 1)

(Ref. 1) 
DESIGN ANALYSIS

Client NUMATEC HANFORD COMPANY

Subject PROJECT W-320 WASTE RETRIEVAL for TANK 241-C-106

Pipe Drainflow and Anti-Siphon Sizing for Transfer Line

Location C TANK FARM - HANFORD 200 EAST AREA
WO/Job No. E09141

Date

Checked

Revised
Calc. No.

Revision No: 0

Paģe No. 13 of 25

Filename monitoymed

By D.L. STONE D $\angle S$

By D.L. EVANS $\$ 28$

By

(Monitor Tube, cont...)

$$
\begin{aligned}
& \text { Reynolds }:=\frac{\mathrm{D}_{\mathrm{e}} \cdot \mathrm{v}_{\mathrm{i}} \cdot \mathrm{\rho}}{\mu} \\
& \text { Reynolds }_{i} \\
& \text { Reynolds Number } \\
& \text { Ref. 6, Eq 3-3 } \\
& 1.917 \cdot 10^{4} \\
& 1.369 \cdot 10^{4} \\
& 8.215 \cdot 10^{3} \\
& 2.738 \cdot 10^{3} \\
& 0.548 \text { (Out of range for formula) } \\
& \text { (Out of range for formula) } \\
& D_{e}=0.091 \cdot f t \\
& \mathrm{k}_{\mathrm{s}}:=.00015 \cdot \mathrm{ft} \\
& \text { Roughness factor for pipe Smooth Commercial Pipe } \\
& \text { (Ref. 4, Pg.419) } \\
& f_{i}=\frac{0.25}{\left(\log \left(\frac{\mathrm{k}_{\mathrm{s}}}{3.7 \cdot \mathrm{d}}+\frac{5.74}{\text { Reynolds }}\right)\right)^{2}} \\
& \begin{array}{l}
\mathrm{f}_{\mathrm{i}} \\
0.0229 \\
\hline 0.0243 \\
0.0269
\end{array} \\
& 0.0269 \\
& 0.0359 \\
& \frac{\mathrm{k}_{\mathrm{s}}}{\mathrm{D}_{\mathrm{e}}}=0.002 \\
& 0.2401 \\
& \text { Friction Factor (for } 4 \times 10^{3}<\operatorname{Re}<10^{8} \text { ) } \\
& \text { Ref. 4, Pg } 424 \\
& \text { (Out of range for formula) } f_{\text {critical }}:=0.045 \\
& h_{\text {monitor }_{i}}:=\left(f_{i}\right) \cdot\left(\frac{18 \cdot i_{n}}{D_{e}}\right) \cdot \frac{\left(v_{i}\right)^{2}}{2 \cdot g} \\
& \mathrm{~h}_{\text {monitor }}=\left[\begin{array}{l}
0 \\
4.036 \\
2.182 \\
0.871 \\
0.129 \\
3.455 \cdot 10^{-8}
\end{array}\right] \cdot \mathrm{ft} \\
& h_{\text {monitor } C}:=\left(f_{\text {critical }}\right) \cdot\left(\frac{18 \cdot \mathrm{in}}{\mathrm{D}_{\mathrm{e}}}\right) \cdot \frac{\left(3.741 \cdot \frac{\mathrm{ft}}{\mathrm{sec}}\right)^{2}}{2 \cdot \mathrm{g}} \\
& \mathrm{h}_{\text {monitorC }}=0.162 * \mathrm{ft}
\end{aligned}
$$

\section{Monitor Tube Losses at $0 \%$ Solids Loading (Water):}

Given / Known Data:

$S G:=1.0$

$\rho_{\mathrm{H} 2 \mathrm{O}}:=62.305 \cdot \frac{\mathrm{lb}}{\mathrm{ft}^{3}}$

$\rho:=\mathrm{SG} \cdot \rho_{\mathrm{H} 2 \mathrm{O}} \quad \rho=62.305 \cdot \frac{\mathrm{lb}}{\mathrm{ft}^{3}}$
Specific Gravity ( $0 \%$ solids loading)

Water Density at $70^{\circ} \mathrm{F}$

Process Fluid Density
(Ref. 1)

(Ref. 6) 
FLUOR DANIEL

NORTHWEST

\section{DESIGN ANALYSIS}

Client NUMATEC HANFORD COMPANY

Subject PROJECT W-320 WASTE RETRIEVAL for TANK 241-C-106

Pipe Drainflow and Anti-Siphon Sizing for Transfer Lines Checked $3 / 25 / 97$

Location C TANK FARM - HANFORD 200 EAST AREA
WO/Job No. E09141

Date $3 / 5 / 97$

Revised
Calc. No.

W-320-27-045

Revision No: 0

Page No. 14 of 25

Filename monitor.med

BY D.L. STONE 2 CS

By D.L. EVANS $D \mathscr{L}$

By

(Monitor Tube, cont...)

$$
\begin{aligned}
& \mu_{0 \%}:=4 \quad \text { Viscosity for } 0 \% \text { solids fluid at } 68 \text { degrees } F \\
& \mu_{0 \% 70}:=\mu_{0 \%}(1-0.005 \cdot(70-68)) \quad \text { Temperature adjustment equation from FDC } \\
& \mu=\mu_{0 \% 70^{c p}} \mathrm{cp} \quad \mu=3.96 \cdot \mathrm{cp} \quad \text { Viscosity for } 10 \% \text { solids fluid at } 50^{\circ} \mathrm{F}
\end{aligned}
$$$$
\text { Reynolds }_{\mathrm{i}}:=\frac{\mathrm{D}_{\mathrm{e}} \cdot \mathrm{v}_{\mathrm{i}} \cdot \rho}{\mu} \quad \text { Reynolds }_{\mathrm{i}} \quad \text { Reynolds Number }
$$

(Ref. 1)

(Ref. 1)

\begin{tabular}{|c|}
\hline $5.562 \cdot 10^{4}$ \\
\hline $3.973 \cdot 10^{4}$ \\
\hline $2.384 \cdot 10^{4}$ \\
\hline $7.946 \cdot 10^{3}$ \\
\hline 1.589 \\
\hline
\end{tabular}

Ref. 6, Eq 3-3

$D_{\mathrm{e}}=0.091 \cdot \mathrm{ft}$

$\mathrm{k}_{\mathrm{S}}:=.00015 \cdot \mathrm{ft} \quad$ Roughness factor for pipe Smooth Commercial Pipe

(Ref. 4, Pg.419)

$$
\begin{aligned}
& \mathrm{f}_{\mathrm{i}}:=\frac{0.25}{\left(\log \left(\frac{\mathrm{k}_{\mathrm{s}}}{3.7 \cdot \mathrm{d}}+\frac{5.74}{\text { Reynolds }}\right)\right)^{2}} \\
& \frac{\mathrm{k}_{\mathrm{s}}}{\mathrm{D}_{\mathrm{e}}}=0.002
\end{aligned}
$$$$
\begin{aligned}
& f_{i} \\
& 0.0201 \\
& 0.0208 \\
& 0.0222
\end{aligned}
$$

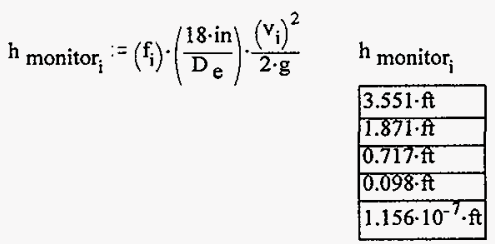


FLUOR DANIEL NORTHWEST

DESIGN ANALYSIS

Client NUMATEC HANFORD COMPANY

Subject PROJECT W-320 WASTE RETRIEVAL fOr TANK 241-C-106 PIPE DRAINFLOW and ANTI-SIPHON SIZING FOR TRANSFER LINES

Location

C TANK FARM 200 EAST AREA
Calc. No. W-320-27-045

Revision No. 0

Page No. 15 of 25

WO/Job No. E09141 Filename curves.xis Date $3 / 5 / 1997$ By Checked 3) $25[97 \quad$ By D. L. STONE D $L S$ Revised
D.L. EVANS \&QP

SUMMARY OF CURVES for INPUT TO PIPE-FLO MODEL

(Appendix $A$ and Pages 10-14)

Immersible Pump $0 \%$ Solids

Free Rotor

Positive Flow

Vertical Inline Pump $0 \%$ Solids

Free Rotor

Positive Flow

Immersible Pump $\quad 0 \%$ Solids

Free Rotor

Reverse Flow

Vertical Inline Pump $0 \%$ Solids Locked Rotor

Reverse Flow

Micromotion

Mass Flow Meter

$10 \%$ Solids

$\frac{Q(\mathrm{gpm})}{\mathrm{H}(\mathrm{ft})}$

\begin{tabular}{|l|l|}
0 \\
\hline
\end{tabular}

50

\begin{tabular}{|r|}
\hline 150 \\
\hline 371 \\
\hline
\end{tabular}

\begin{tabular}{l|l|r|}
\hline 3.714 & 9.286 & 17.128 \\
\hline
\end{tabular}

$30 \%$ Solids

\begin{tabular}{|c|c|c|c|c|c|}
\hline$Q(\mathrm{gpm})$ & 0 & 50 & 150 & 250 & 350 \\
\hline$H(\mathrm{fi})$ & 0 & 2.311 & 7.704 & 19.26 & 33.705 \\
\hline
\end{tabular}

Monitor Tube $\quad 0 \%$ Solids

\begin{tabular}{|c|c|c|c|c|c|}
\hline$Q(\mathrm{gpm})$ & 0 & 50 & 150 & 250 & 350 \\
\hline$H(\mathrm{ft})$ & 0 & 0.098 & 0.717 & 1.87 & 3.55 \\
\hline
\end{tabular}

$10 \%$ Solids

\begin{tabular}{|c|c|c|c|c|c|}
\hline Q $(\mathrm{gpm})$ & 0 & 50 & 150 & 250 & 350 \\
\hline H $(\mathrm{ft})$ & 0 & 0.13 & 0.87 & 2.18 & 4.04 \\
\hline
\end{tabular}


NORTHWEST

\section{DESIGN ANALYSIS}

Client NUMATEC HANFORD COMPANY

Subject PROJECT W-320 WASTE RETRIEVAL. for TANK 241-C-106

Pipe Drainflow and Anti-Siphon Sizing for Transfer Line Location C TANK FARM - HANFORD 200 EAST AREA
WOJJob No. E09141

Date $\quad 3 / 5 / 97$

Checked $3 / 25197$ Revised
Calc. No. W-320-27-045

Revision No: 0

Page No. $\quad 16$ of 25

Filename slurylist.med

BY D.L. STONE DCS

By M.D. BROCKETT M

\section{SLURRY TRANSFER LINE - Identification and Configuration}

Node Name: $\sim N-0 \quad$ Elevation: ImPumpSuction $:=608.0 \cdot \mathrm{ft}$

(Ref. 15.8 \& Lawrence Pump Data (Appx. M))

Pipe Name: Pipe 0

$L_{\text {Pipe } 0}:=5.31 \cdot$ in

$\mathrm{L}_{\text {Pipe } 0}=0.442 \cdot \mathrm{ft}$

- Pipe-FLO Pressure Source at 0 psig at $\mathrm{O} f \mathrm{f}$ (conservative)

(5" Suction Diameter)

- 1, entrance (exit, for Siphoning)

Node Name: $\sim N-1 \quad$ Elevation: ImPumpDischarge $:=$ ImPumpSuction $+5.31 \cdot$ in

ImPumpDischarge $=608.443 \cdot \mathrm{ft}$

(Ref. 15.0 \& Lawrence Pump Data (Appx. M))

Pipe Name: Pipe 1

$\mathrm{L}_{\text {vPipel }}:=(3+4+2 \cdot(4.875)) \cdot$ in $\quad$ (Ref. 15.0)

(3" Line)

$\mathrm{L}_{\text {hPipel }}:=(8.125+3) \cdot$ in

(Ref. 11 (Appx. M))

$\mathrm{L}_{\text {Pipe1 }}:=\mathrm{L}_{\mathrm{vPipe}}+\mathrm{L}_{\text {hPipel }} \quad \mathrm{L}_{\text {Pipel }}=2.323 \cdot \mathrm{ft}$

- Immersible Pump Component

1 el, 1 Swivel--> $-3,3$ 3", $90^{\circ} \mathrm{SR}$ els

$-1,4 \times 3$ enlarger -4 " approach

BoosterPumpSuction : $=639 \cdot \mathrm{ft}+1.281 \cdot$ in

Node Name: $\sim \mathrm{N}-\mathrm{-2} \quad$ Elevation: $\quad$ Reducer $_{4 \times 3}:=$ ImPumpDischarge $+1.396 \cdot \mathrm{ft}$

Reducer $_{4 \times 3}=609.838 \cdot \mathrm{ft}$

(Ref. 11, $15.8 \& 15.2$ )

Pipe Name: Pipe 2

$L_{\text {vPipe } 2}:=$ BoosterPumpSuction - Reducer $4 \times 3$

$\mathrm{L}_{\text {vPipe2 }}=29.268 \cdot \mathrm{ft}$

(4" Line)

$$
\mathrm{L}_{\mathrm{hPipe} 2}:=(2 \cdot(10.125)+12.29+18.97+15.6) \cdot \text { in } \quad \mathrm{L}_{\mathrm{hPipe} 2}=5.592 \cdot \mathrm{ft}
$$

$\mathrm{L}_{\text {Pipe2 }}:=\mathrm{L}_{\text {vPipe2 }}+\mathrm{L}_{\text {hPipe2 }} \quad \mathrm{L}_{\text {Pipe2 }}=34.861 \cdot \mathrm{ft}$

$-1,4^{\prime \prime}, 45^{\circ} \mathrm{SR}$ el

2 Swivels $\rightarrow-4,4^{\prime \prime}, 90^{\circ} \mathrm{SR}$ els

$-2,4^{\prime \prime}, 90^{\circ} \mathrm{LR}$ els

$-1,4^{\prime \prime}, 90^{\circ} \mathrm{SR}$ el

Jumper Connector-->. $1,4^{\prime \prime}$ miter bend

Node Name: $\sim \mathrm{N}-2.1 \quad$ Elevation: $\quad$ BoosterPumpSuction $=639.107 \cdot \mathrm{ft} \quad$ (Ref. 15.8 \& 15.9)

Pipe Name: Pipe 2.1 L Lipe2.1 $:=1 \cdot \mathrm{ft}$

(4" Line - Pipe 2.1 modeled to support components not included in this calulation.) 
FLUOR DANIEL

NORTHWEST

Client NUMATEC HANFORD COMPANY

Subject PROSECT W-320 WASTE RETRIEVAL for TANK 241-C-106

Pipe Drainflow and Anti-Siphon Sizing for Transfer Line

Location C TANK FARM - HANFORD 200 EAST AREA

\section{DESIGN ANALYSIS}

Wo/Job No. E09141

Date $3 / 5 / 97$

Checked

Revised
Calc. No.

W-320-27-045

Revision No:: 0

Page No. 17 of 25

Filename slurylist.mcd

By D.L. STONE DCS

By

By

\section{(SLURRY LINE- cont..)}

Node Name: $\sim \mathrm{N}-\mathrm{-2.2} \quad$ Elevation: BoosterPumpSuction $=639.107 \cdot f t \quad$ (Ref. 15.9)

Pipe Name: Pipe 3

(3" Line)

$$
\begin{array}{cl}
\mathrm{L}_{\text {Pipe3 }}:=4 \cdot \mathrm{ft}+9.2 \cdot \mathrm{in} \quad \mathrm{L}_{\text {Pipe3 }}=4.767 \cdot \mathrm{ft} \quad & -90^{\circ} \mathrm{el} \mathrm{4"} \mathrm{LR} \\
& -4 \times 3 \text { reducer, } 4^{\prime \prime} \text { approach } \\
& - \text { Pump Backflow Component } \\
& -4 \times 3 \text { enlgr, } 4^{\prime \prime} \text { approach } \\
& -90^{\circ} \mathrm{el} 4^{\prime \prime} \mathrm{LR}
\end{array}
$$

Node Name: $\sim \mathrm{N}-\mathrm{-3}$ Elevation: BoosterPumpDischarge := BoosterPumpSuction $+4.25 \cdot$ in (Ref, 15.9)

Pipe Name: Pipe 3.1

$$
\text { BoosterPumpDischarge }=639.461 * \mathrm{ft} \quad \text { (Checkpoint } 1)
$$

(4" Line)

$$
\begin{aligned}
& \mathrm{L}_{\text {vPipe3.1 }}:=(1 \cdot \mathrm{ft}+2.9 \cdot \mathrm{in})+(1 \cdot \mathrm{ft}+5.8 \cdot \mathrm{in}) \\
& \mathrm{L}_{\mathrm{hPipe} .1}:=(12 \cdot \mathrm{ft}+7 \cdot \mathrm{in})+2 \cdot \mathrm{ft} \\
& \text { Jumper }:=\mathrm{L}_{\text {vPipe3.1 }}+\mathrm{L}_{\mathrm{hPipe}} .1 \\
& \mathrm{~L}_{\text {Pipe3.1 }}:=410.3 \cdot \mathrm{ft}+\text { Jumper } \\
& \mathrm{L}_{\text {Pipe3.1 }}=427.608 \cdot \mathrm{ft}
\end{aligned}
$$$$
\mathrm{L}_{\text {vPipe }} .1=2.725 \cdot \mathrm{ft}
$$$$
\mathrm{L}_{\text {hPipe3.1 }}=14.583 \cdot \mathrm{ft}
$$$$
\text { Jumper }=17.308 \cdot \mathrm{ft}
$$$$
\text { (Ref. } 15.1 \text { \& 15.4) }
$$

(Ref. $15.10 \& 15.9$ )

(Ref. 15.10)

2 jmpr conn $=$ miter bend $4 "$ $390^{\circ} \mathrm{el} 4^{\prime \prime} \mathrm{LR}$

6. 4" $90^{\circ}$ Bends $\%=10$

2, 4" $45^{\circ}$ Bends $\% d=9$

Pipe Name: Pipe 3.2 .

(4" Line)

$$
L_{\text {Pipe3.2 }}:=468.1 \cdot f t
$$

\section{4" $90^{\circ}$ Bends $\%=10$}

Node Name: $\sim \mathrm{N}-3.2 \quad$ Elevation: Checkpoint $3:=661.63 \cdot \mathrm{ft}$
(Ref. 15.1 \& 15.5)

Pipe Name: Pipe 3.3
(4" Line)
$L_{\text {Pipe3.3 }}:=843.2$
11, $4^{\prime \prime} 90^{\circ}$ Bends $1 / d=10$

Node Name: $\sim \mathrm{N}--3.3 \quad$ Elevation: SystemHighpoint $: \mathbf{0} 676.05 \cdot \mathrm{ft} \quad$ (Ref. 15.1)
Pipe Name: Pipe 3.4
$\mathrm{L}_{\text {Pipe } 3.4}:=(15.504+1.583) \cdot$ in
- $1 \mathrm{jmpr}$ conn $=$ miter bend $4 "$
(4" Line)
$\mathrm{L}_{\text {Pipe3.4 }}=1.424 \cdot \mathrm{ft}$
$-1,90^{\circ}$ el $4^{\prime \prime}$ LR
$-1,4 \times 3$ reducer $-4^{\prime \prime}$ approach 
FLUOR DANIEL

NORTHWEST

DESIGN ANALYSIS

Client NUMATEC HANFORD COMPANY

Subject PROJECT W-320 WASTE RETRIEVAL, for TANK 241-C-106

Pipe Drainflow and Anti-Siphon Sizing for Transfer Line

Location C TANK FARM - HANFORD 200 EAST AREA
Calc. No.

W-320-27-045

Revision No: 0

Page No. 18 of 25

WO/Job No. E09141

Date $\quad 3 / 5 / 97$

Checked

Revised

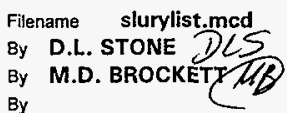

(SLURRY LINE- cont..)

Node Name: $\sim N-4$ Elevation: Micromotion in a SystemHighpoint - 15.375-in

(Ref. 15.11)

$$
\text { Micromotion in }=674.769 \cdot \mathrm{ft}
$$

Pipe Name: Pipe 4

(3" Line)

$L_{\text {Pipe4.1 }}=(5.427 \cdot \mathrm{ft}-34.562 \cdot \mathrm{in})+(2+5.292) \cdot \mathrm{in}$

$-1,90^{\circ} \mathrm{el} 3^{\prime \prime} \mathrm{LR}$

- Micromotion Flowmeter

$L_{\text {Pipe } 4.1}=3.155 \cdot \mathrm{ft}$

$-1,3$-way Ball Valve, $C v=228$

Node Name: $\sim N-4.1$ Elevation: Micromotion out $=$ Micromotion in

(Ref. 15.11)

Micromotion out $=674.769 \cdot \mathrm{ft}$

Pipe Name: Pipe 5

$L_{\text {Pipe5 }}:=(9.958+5.292 \div 30.844) \cdot$ in

(Ref. 15.11)

(4" Line)

$\mathrm{L}_{\text {Pipe5 }}=3.841 \cdot \mathrm{ft}$

$-1,4 \times 3$ enlarger $-4 "$ approach

- 3, $90^{\circ} \mathrm{el} 4^{\prime \prime}$ LR

- $\uparrow$ jmpr conn = miter bend 4"

Node Name: $\sim \mathrm{N}-5 \quad$ Elevation: Nozzle :=SystemHighpoint $-(1 \cdot \mathrm{ft}+9.375 \cdot \mathrm{in}) \quad$ (Ref. 15.11)

Nozzle $=674.269 \cdot \mathrm{ft}$

Pipe Name: Pipe 5.1

$\mathrm{L}_{5.1}:=7 \cdot \mathrm{ft}+8 \cdot \mathrm{in}$

$\mathrm{L}_{5.1}=7.667 \cdot \mathrm{ft}$

(Ref. 15.14)

$\left(4^{\prime \prime}\right.$, Sched. 80 Line)

Node Name: $\sim N-5.1 \quad$ Elevation: SiphonHole : $=665.8 \cdot \mathrm{ft} \quad\left(2,1 / 2^{\prime \prime}\right.$ holes $)$

(Ref. 15.1)

Pipe Name: Pipe 5.2

$L_{\text {Pipe } 5}:=(37-7) \cdot f t-7.75 \cdot$ in $\quad L_{\text {Pipe } 5}=29.354 \cdot f t$

(Ref. 15.14)

(4", Sched. 80 Line)

$\begin{array}{lll} & \text { LowerNozzles : }=635.91 \cdot \mathrm{ft} \quad \text { (Ref. 15.1) } \\ \text { Node Name: } \sim \mathrm{N}-6 \quad \text { Elevation: } \quad \text { UpperNozzles : }=\text { LowerNozzles }+7.75 \cdot \mathrm{in} \quad \text { (Ref. 15.14) } \\ & \text { UpperNozzles }=636.556 \cdot \mathrm{ft}\end{array}$

Distributor Nozzle Pressure Sources: (Maximum Liquid Level)

$$
\mathrm{H}_{\text {UpperNozzles }}:=653.66 \cdot \mathrm{ft}-\text { UpperNozzles }
$$

$\mathrm{H}_{\text {UpperNozzles }}=17.104 \cdot \mathrm{ft}$ 
FLUOR DANIEL

NORTHWEST

DESIGN ANALYSIS

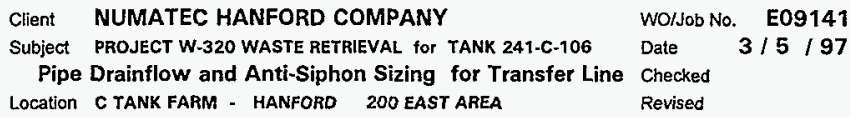

Calc. No.

W-320-27-045

Revision No.: 0

Page No. 19 of 25

Filename slurylist.med

BY D.L. STONE D 15

By M.D. BROCKETT MS

(SLURRY LINE- cont..)

Node Name: $\sim \mathrm{N}-6.1$

Pipe Name: Pipe $6.1 \quad$ (2" , Sched. 80 Line)

$L_{\text {Pipe } 5.1}:=0.5 \cdot f t \quad-1$, exit (entrance, for Siphoning)

Node Name: $\sim \mathrm{N}-6.2$

Pipe Name: Pipe 6.2 (2" , Sched. 80 Line)

$\mathrm{L}_{\text {Pipe5.2 }}:=0.5 \cdot \mathrm{ft} \quad-1$, exit (entrance, for Siphoning)

Node Name: $\sim \mathrm{N}-7 \quad$ Elevation: LowerNozzles := $635.91 \cdot \mathrm{ft}$

(Ref. $15.1 \& 15.14)$

Pipe Name: Pipe 7

$L_{\text {Pipe } 7}:=7.75 \cdot$ in

$L_{\text {Pipe } 7}=0.646 \cdot f t$

(4" Line)

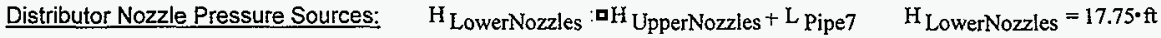
(Maximum Liquid Level)

Node Name: $\sim \mathrm{N}-7.1$

Pipe Name: Pipe $7.1 \quad$ (4", Sched. 80 Line)

$L_{\text {Pipe6.1 }}:=6 \cdot$ in $\quad L_{\text {Pipe6.1 }}=0.5 \cdot f t$

-1 ecc. $4 \times 2$ reducer (enlarger, for Siphoning)

Node Name: $\sim N-7.11$

Pipe Name: Pipe $7.11 \quad$ (2" , Sched. 80 Line)

$\mathrm{L}_{\text {Pipe6.11 }}:=2 \cdot$ in $\quad \mathrm{L}_{\text {Pipe6.11 }}=0.167 \cdot \mathrm{ft}$

- 1, exit (entrance, for Siphoning)

Node Name: $\sim \mathrm{N}-7.2$

Pipe Name: Pipe 7.2 (4", Sched. 80 Line)

$\mathrm{L}_{\text {Pipe6.2 }}:=6 \cdot \mathrm{in} \quad \mathrm{L}_{\text {Pipe }} .2=0.5 \cdot \mathrm{ft}$

-1 ecc. $4 \times 2$ reducer (enlarger, for Siphoning)

Node Name: $\sim N-7.22$

Pipe Name: Pipe $7.22 \quad$ (2" , Sched. 80 Line)

$\mathrm{L}_{\text {Pipe6.22 }}=2 \cdot$ in $\quad \mathrm{L}_{\text {Pipe6.22 }}=0.167 \cdot \mathrm{ft}$

- 1, exit (entrance, for Siphoning) 
FLUOR DANIEL

NORTHWEST

DESIGN ANALYSIS

Client NUMATEC HANFORD COMPANY

Subject PROJECT W-320 WASTE RETRIEVAL for TANK 241-C-106

Pipe Drainflow and Anti-Siphon Sizing for Transfer Lines

Location

C TANK FARM

HANFORD

200 EAST AREA
WOIJob No. E09141

Date $3 / 5 / 97$

Checked

Revised
Calc. No.

W-320-27-045

Revision No:: $\mathbf{0}$

Page No. 20 of 25

Filename suprlist.mcd

By D.L. STONE DLS

By M.D. BROCK

By

\section{SUPERNATE LINE - Identification and Configuration}

Node and Pipe Names, Elevations, Pipe Diameters, Pipe Lengths, Fittings and Pressure Sources

Node Name: $\sim \mathrm{N}-\mathrm{O}$ Elevation: ImPumpSuction $:=635.5 \cdot \mathrm{ft}$

(Ref. 15.8 \& Lawrence Pump Data (Appx. M))

Pipe Name: Pipe 0

$$
L_{\text {vPipe } 0}:=5.31 \cdot \text { in } \quad L_{\text {vPipe } 0}=0.442 \cdot f t
$$

( 5 " Suction Diameter)

$$
\begin{aligned}
& \text { Submergence }:=(653.66-635.5) \cdot \mathrm{ft} \\
& \text { Submergence }=18.16 \cdot \mathrm{ft}
\end{aligned}
$$

- Pipe-FLO Pressure Source at 0 psig at $17.77 \mathrm{ft}$

- Pump entrance

Node Name: $\sim \mathrm{N}-1$ Elevation: ImPumpDischarge : = ImPumpSuction $+5.31 \cdot$ in

$$
\text { ImPumpDischarge }=635.943 \cdot \mathrm{ft}
$$

Pjpe Name: Pipe $1 \quad \mathrm{~L}$ vPipel $:=(3+4+2 \cdot(4.875)) \cdot$ in $\quad$ (Ref. 15.0)

(3" Line)

$\mathrm{L}_{\text {hPipel }}:=(8.125+3) \cdot$ in $\quad$ (Ref. 11 (Appx. M))

$$
\mathrm{L}_{\text {Pipel }}:=\mathrm{L}_{\text {vPipel }}+\mathrm{L}_{\text {hPipel }} \quad \mathrm{L}_{\text {Pipel }}=2.323 \cdot \mathrm{ft}
$$

- Immersible Pump (Component curves)

1 el +1 Swivel- $\rightarrow-3,3^{\prime \prime}, 90^{\circ} \mathrm{SR}$ els

$-1,4 \times 3$ enlarger - 4" approach

$$
\text { SiphonHole }:=661.7 \cdot \AA
$$

Node Name: $\sim \mathrm{N}-2.1$ Elevation: Reducer $4 \times 3$ := ImPumpDischarge $+\mathrm{L}_{\mathrm{vPipel}}$

$$
\text { Reducer } 4 \times 3=637.338 \cdot \mathrm{ft}
$$

Pipe Name: Pipe 2.1 L L $_{\mathrm{vPipe} 2.1}:=$ (SiphonHole - ImPumpSuction $)-\left(L_{\mathrm{vPipe} 0}+\mathrm{L}_{\mathrm{vPipe}}\right) \quad$ (Ref. 15.8) (4" Line)

$$
\begin{aligned}
& \mathrm{L}_{\text {hPipe2.1 }}:=2 \cdot(10.125 \cdot \mathrm{in}) \quad(\text { Ref.11 } \\
& \text { (Appx.M) } \\
& \mathrm{L}_{\text {Pipe2.1 }}:=\mathrm{L}_{\text {VPipe2.1 }}+\mathrm{L}_{\text {hPipe2.1 }} \quad \mathrm{L}_{\text {Pipe2.1 }}=26.049 \cdot \mathrm{ft}
\end{aligned}
$$

$$
2 \text { Swivels-.> }-4,4^{\prime \prime}, 90^{\circ} \mathrm{SR} \text { els }
$$


FLUOR DANIEL

NORTHWEST

Client NUMATEC HANFORD COMPANY

Subject PROJECT W-320 WASTE RETRIEVAL for TANK 241-C-106

Pipe Drainflow and Anti-Siphon Sizing for Transfer lines

Location C TANK FARM - HANFORD
DESIGN ANALYSIS

WO/Job No. E09141

Date $\quad 3 / 5 / 97$

Checked

Revised
Caic. No. W-320-27-045

Revision No.: 0

Page No. 21 of 25

Filename suprlist.mcd

By D.L. STONE $D C$

By

By

(SUPERNATE LINE- cont.)

$$
\begin{array}{ll}
\text { Elv PlatetoSuction : }=9.313 \cdot \text { in } & \text { (Ref. 15.16) } \\
\text { Elv Plates := 2·(1.5.in) } & \text { (Ref. 15.3, Pg 2) } \\
\text { Elv PlatetoLap : }=15.25 \cdot \text { in } & \text { (Ref. 15.3. Pg 2) } \\
\text { Elv LaptoHole }:=(102.75-8) \cdot \text { in } & \text { (Ref. 15.3, Pg 2) }
\end{array}
$$

Node Name: $\sim \mathrm{N}-2.2$ Elevation: SiphonHole $:=671.115 \cdot \mathrm{ft}-($ Elv Plates + Elv PlatetoLap + Elv LaptoHole $)$

$$
\text { SiphonHole }=661.7 * \mathrm{ft}
$$

Pipe Name: Pipe $2.2 \quad \mathrm{~L}_{\text {vPipe } 2.2}:=($ Elv Plates + Elv PlatetoLap +Elv LaptoHole $)+$ Elv PlatetoSuction

(4" Line)

$$
\begin{aligned}
& L_{\text {vPipe } 2.2}=10.193 \cdot \mathrm{ft} \\
& \mathrm{L}_{\text {hPiping }}:=(12.29+18.97) \cdot \text { in } \quad \text { (Ref. 15.2, Pg 2) } \\
& L_{\text {hJumper }}:=(17.5+46+7) \cdot \text { in } \text { (Ref. 15.16. Pg 3) } \\
& \mathrm{L}_{\text {Pipe2.2 }}:=\mathrm{L}_{\text {vPipe2.2 }}+\mathrm{L}_{\text {hPiping }}+\mathrm{L}_{\text {hJumper }} \quad \mathrm{L}_{\text {Pipe2.2 }}=18.673 \cdot \mathrm{ft} \\
& -4,4^{\prime \prime}, 90^{\circ} \mathrm{LR} \text { els } \\
& -1,4^{\prime \prime}, 90^{\circ} \mathrm{SR} \text { el } \\
& \text { Jumper Connector--> } 1,4 \text { " miter bend } \\
& \text { - 4", 2-way PBM Ball Valve, } \mathrm{Cv}=650
\end{aligned}
$$

$$
\begin{aligned}
\mathrm{L}_{\text {Pipe3 }}:=2 \cdot(4 \cdot \mathrm{in}) \quad \mathrm{L}_{\text {Pipe3 }}=0.667 \cdot \mathrm{ft} & -1,4 \times 3 \text { reducer }-4 " \text { approach } \\
& - \text { Vertical Inline Pump (Component curves) } \\
& -1,4 \times 3 \text { enlarger }-4 " \text { approach }
\end{aligned}
$$


FLUOR DANIEL NORTHWEST

Client NUMATEC HANFORD COMPANY

SUbject PROJECT W-320 WASTE RETRIEVAL for TANK 241-C-106

Pipe Drainflow and Anti-Siphon Sizing for Transfer Lines

Location C TANK FARM - HANFORD 200 EAST AREA

\section{DESIGN ANALYSIS}

WO/Job No. E09141

Date $3 / 5 / 97$

Checked

Revised
Calc. No. W-320-27-045

Revision No.: 0

Page No. 22 of 25

Filename suprlist.mcd

BY D.L. STONE ID $S$

BY M.D. BROCKETT MP

(SUPERNATE LINE- cont..)

SystemHighpoint : $=677.11 \cdot \mathrm{ft}$

Node Name: $\sim \mathrm{N}-3$ Elevation: BoosterPumpDischarge : $=(677.073-4.404) \cdot \mathrm{ft}$

(Ref. 15.16)

BoosterPumpDischarge $=672.669 \cdot \mathrm{ft}$

Pipe Name: Pipe $3 \quad L_{\text {vPipe3 }}:=$ (SystemHighpoint - BoosterPumpDischarge) $L_{\text {vPipe3 }}=4.441 \cdot \mathrm{ft}$

(4" Line)

$$
\begin{array}{ll}
\mathrm{L}_{\text {hPipe3 }}:=(12.9+15.25) \cdot \text { in } & \mathrm{L}_{\text {hPipe3 }}=2.346 \cdot \mathrm{ft} \\
\mathrm{L}_{\text {Pipe3 }}:=\mathrm{L}_{\text {vPipe3 }}+\mathrm{L}_{\text {hPipe3 }} & \mathrm{L}_{\text {Pipe3 }}=6.787 \cdot \mathrm{ft}
\end{array}
$$

(Ref. 15.16)

Jumper Conn- $-1,4^{\prime \prime}$ miter bend

$-3,4^{\prime \prime}, 90^{\circ} \mathrm{LR}$ els

$-1,4 \times 1$ Tee, thru Run

Node Name: $\sim \mathrm{N}-4$ Elevation: SystemHighpoint $:=677.11 \cdot \mathrm{ft}$

(Ref. 15.1\& 15.7)

Pipe Name: Pipe 4.1

$L_{\text {Pipe4.1 }}:=822.8 \cdot \mathrm{ft}$

$-10,4 ", 90^{\circ}$ Bends $1 / d=10$

(4" Line)

Node Name: $\sim \mathrm{N}-5 \quad$ Elevation: Checkpoint $3:=661.63 \cdot \mathrm{ft}$

(Ref. 15.1 \& 15.5)

Pipe Name: Pipe 4.2

$L_{\text {Pipe } 4.2}:=468.1 \cdot \mathrm{ft}$

$-4,4 ", 90^{\circ}$ Bends $r / \%=10$

(4" Line)

Node Name: $\sim \mathrm{N}-6 \quad$ Elevation: Checkpoint $2:=650.39 \cdot \mathrm{ft}$

(Ret. $15.1 \& 15.4$ )

Pipe Name: Pipe 4.3

L Pipe4.3 : $=428.7 \cdot \mathrm{ft}$

5. 4" $90^{\circ}$ Bends $1 / d=10$

(4" Line)

2. $4^{\prime \prime} 45^{\circ}$ Bends $1 / d=9$ 
FLUOR DANIEL

NORTHWEST

\section{DESIGN ANALYSIS}

Client NUMATEC HANFORD COMPANY

Subject PROJECT W-320 WASTE RETRIEVAL for TANK 241.C-106

Pipe Drainflow and Anti-Siphon Sizing for Transfer Lines Location C TANK FARM - HANFORD 200 EAST AREA
WO/Job No. E09141

Date $3 / 5 / 97$

Checked

Revised
Cale. No.

W-320-27-045

Revision No.: 0

Page No. 24 of 25

Filename supritst.med

BY D.L. STONE D $/ S$

BY M.D. BROCKETT

By

\section{(SUPERNATE LINE- cont..)}

Node Name: $\sim \mathrm{N}-10$ Elevation: Monitor ${ }_{\text {Top }}:=$ Modified Swivel $-8 \cdot$ in

(Ref. 15.18) Monitor Top $=621.85 \cdot \mathrm{ft}$

Pipe Name: Pipe 7

(2.5" Line)

$$
L_{\text {Pipe } 7}:=(12.94+1.5) \cdot \text { in } \quad L_{\text {Pipe7 }}=1.203 \cdot \mathrm{ft}
$$

- Monitor Component Curve

Node Name: $\sim \mathrm{N}-11$ Elevation: Nozzle In $:=$ Monitor Top $-(18+1.5) \cdot$ in

(Ref. 15.20)

Nozzle $_{\text {In }}=620.225 \cdot f t$

$-1,2.5 \times 1$ reducer $-7.25^{\prime \prime}$ approach

Pipe Name: Pipe 8

$$
L_{\text {Pipe8 }}:=7.25 \cdot \text { in } \quad L_{\text {Pipe8 }}=0.604 \cdot f t
$$

(2.5" Line - reducer, oniy)

$\begin{array}{lll}\text { Node Name: } \sim \mathrm{N}-12 & \text { Elevation: } & \text { Nozzle Out }:=\text { Nozzle }_{\mathrm{In}}-(7.25) \cdot \mathrm{in} \\ & \text { Nozzle Out } & =619.621 \cdot \mathrm{ft}\end{array}$

Pipe Name: Pipe 9

$$
L_{\text {Pipe9 }}:=3.25 \cdot \text { in } \quad L_{\text {Pipe9 }}=0.271 \cdot f t
$$

Node Name: $\sim \mathrm{N}-13$ Elevation: End := Nozzle Out $-3.25 \cdot$ in

$$
\text { End }=619.35 \cdot \text { ft }
$$

(Ref. 15.20)

- Pipe-FLO Pressure Source, 0 psig at $0 \mathrm{ft}$ submergence 
DESIGN ANALYSIS

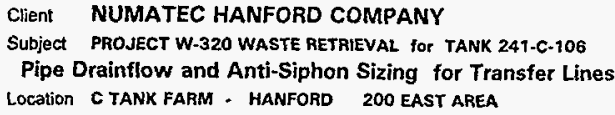

Calc. No.

W-320-27-045

Revision No:: 0

Page No. 23 of 25

\section{Filename suprlist.mcd \\ BY D.L. STONE D $L S$ \\ BY M.D. BROCKETL TEP}

(SUPERNATE LINE: cont.)

$$
\begin{aligned}
& \text { SluicerFlange Top }:=638.33 \cdot \mathrm{ft} \quad(\text { Ref. 15.21) } \\
& \text { Modified } \left.{ }_{\text {Swivel }}:=\text { (SluicerFlange }_{\text {Top }}-15.813 \cdot \mathrm{ft}\right) \quad \text { (Ref. 15.21) }
\end{aligned}
$$

Node Name: $\sim$ N-7 Elevation: PitNozzle $\mathrm{C106}:=641.42 \cdot \mathrm{ft} \quad$ (Checkpoint 1 ) (Ref. 15.1)

Pipe Name: Pipe 4.4

$L_{\text {vPipe } 44}:=($ PitNozzle C106-Modified Swivel $-8.4 \cdot$ in $)$ (Ref. 15.18)

(4" Line)

$$
\begin{aligned}
& \mathrm{L}_{\text {Jumper }}:=(5.464+1.33) \cdot \mathrm{ft} \quad \text { (Ref. 15.17) } \\
& \mathrm{L}_{\text {Template }}:=15.25 \cdot \mathrm{in} \quad \text { (Ref. 15.19) } \\
& \mathrm{L}_{\text {hPipe4.4 }}:=\mathrm{L}_{\text {Jumper }}+\mathrm{L}_{\text {Template }} \\
& \mathrm{L}_{\text {Pipe } 4.4}:=\mathrm{L}_{\text {vPipe4.4 }}+\mathrm{L}_{\text {hPipe4.4 }} \quad \mathrm{L}_{\text {Pipe } 4.4}=26.268 \cdot \mathrm{f}
\end{aligned}
$$

$-5,4^{\prime \prime}, 90^{\circ}$ LR els

$-2,4^{\prime \prime}$ miter bend

$-2,4 ", 45^{\circ} \mathrm{SR}$ el

$-1,4 \times 2.5$ reducer -4 " approach

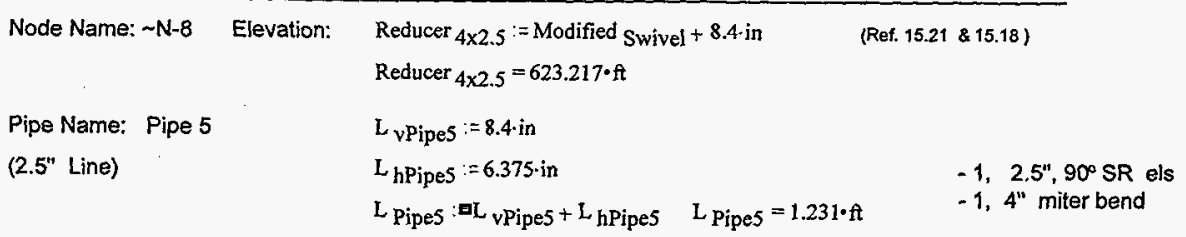

Node Name: $\sim \mathrm{N}-9 \quad$ Elevation: Modified Swivel $=622.517 \cdot \mathrm{ft}$

(Ref. 15.21 \& 15.18)

Pipe Name: Pipe 6

$L_{\text {Pipe6 }}:=8 \cdot$ in $\quad L_{\text {Pipe6 }}=0.667 \cdot \mathrm{ft}$

$-1,2 \times 2.5$ enlarger - 3.5" approach (2" Line) 
FLUOR DANIEL NORTHWEST
DESIGN ANALYSIS

Client NUMATEC HANFORD COMPANY

Subject PROJECT W-320 WASTE RETRIEVAL for TANK 241.C-106

Pipe Drainflow and Anti-Siphon Sizing for Transfer Lines

Location C TANK FARM - HANFORD 200 EAST AREA
WO/Job No. E09141

Date $3 / 5 / 97$

Checked

Revised
Calc. No. W-320-27-045

Revision No.: 0

Page No. 24 of

(SUPERNATE LINE- cont..)

Node Name: $\sim \mathrm{N}-10$ Elevation: Monitor Top := Modified Swivel $-8 \cdot$ in

(Ref. 15.18)

Monitor Top $=621.85 \cdot \mathrm{ft}$

Pipe Name: Pipe 7

(2.5" Line)

$\mathrm{L}_{\text {Pipe } 7}:=(12.94+1.5) \cdot$ in $\quad L_{\text {Pipe }}=1.203 \cdot \mathrm{ft}$

- Monitor Component Curve

Node Name: $\sim N-11$ Elevation: Nozzle In $:=$ Monitor Top $-(18+1.5) \cdot$ in

(Ref. 15.20)

Nozzle $_{\text {In }}=620.225 \cdot \mathrm{ft}$

$-1,2.5 \times 1$ reducer -7.25 " approach

Pipe Name: Pipe 8

$L_{\text {Pipe } 8}:=7.25 \cdot$ in $\quad L_{\text {Pipe8 }}=0.604 \cdot f t$

(2.5" Line - reducer, only)

$\begin{aligned} \text { Node Name: } \sim \mathrm{N}-12 \text { Elevation: } & \text { Nozzle Out }:=\text { Nozzle }_{\text {In }}-(7.25) \cdot \text { in } \\ & \text { Nozzle Out }=619.621 \cdot \mathrm{ft}\end{aligned}$

(Ref. 15.20)

Pipe Name: Pipe 9

(1", Schedule 80 Line)

$L_{\text {Pipe9 }}:=3.25 \cdot$ in $\quad L_{\text {Pipe } 9}=0.271 \cdot f t$

- Exit

$\begin{array}{ll}\text { Node Name: } \sim \mathrm{N}-13 \quad \text { Elevation: } & \text { End }:=\text { Nozzle Out }-3.25 \cdot \text { in } \\ & \text { End }=619.35 \cdot \mathrm{ft}\end{array}$
(Ref. 15.20)

- Pipe-FLO Pressure Source, 0 psig at $0 \mathrm{ft}$ submergence 
FLUOR DANIEL NORTHWEST

Client NUMATEC HANFORD COMPANY

Subject PROJECT W-320 WASTE RETRIEVAL for TANK 241-C-106

Pipe Drainflow and Anti-Siphon Sizing for Transfer Lines

Location C TANK FARM - HANFORD 200 EAST AREA
DESIGN ANALYSIS

WO/Job No. E09141

Date $\quad 3 / 5 / 97$

Checked $3 / 25197$

Revised
Calc. No.

W-320-27-045

Revision No.: 0

Page No. 25 of 25

Filename time.mcd

BY D.L. STONE $\$ 28$

By

D.L. EVANS Q $Q$

By

\section{Basic Calculation for Determination of Time to Drain Pipelines}

The following calculation exemplifies the method used to estimate the time for each pipe in the two Piping Systems to drain. The Excel spreadsheet shown on Page 8 repeats this calculation for each pipe in the system and sums the results.

\section{EXAMPLE: Pipe 3.1}

$\mathrm{d}:=4.03 \cdot \mathrm{in}$

$$
A:=\left(\frac{\pi \cdot d^{2}}{4}\right)
$$

$L:=428.91 \cdot \mathrm{ft}$

$\mathrm{V}:=\mathrm{A} \cdot \mathrm{L}$
Pipe Name

Pipe Inner Diameter

$\mathrm{A}=0.089 \cdot \mathrm{ft}^{2} \quad$ Cross sectional Area of Pipe

Pipe Length

$\mathrm{V}=284.207 \cdot \mathrm{gal} \quad$ Pipe Volume

1.

The following method is used, and the results for each pipe summed, for the pipeline from the lower station point ( $1 / 3$ of the distance up the pipe to the transfer line lowpoint) to the end of the line.

Q Lowpoint := $122.3 \cdot \frac{\mathrm{gal}}{\mathrm{min}}$

Drain Flowrate from Highpoint, provided by Pipe-Flo

$\mathrm{T}:=\frac{\mathrm{V}}{\mathrm{Q} \text { Lowpoint }} \quad \mathrm{T}=2.324 \cdot \mathrm{min} \quad$ Time required to drain Pipe at the given Flowrate

2.

The following method is used, and the results for each pipe summed, for the pipeline from the system highpoint to the lower station point ( $1 / 3$ of the distance up the pipe to the transfer line lowpoint.)

$$
\begin{aligned}
& Q_{\text {High }}:=122.3 \cdot \frac{\mathrm{gal}}{\mathrm{min}} \\
& Q_{\text {Station }}:=141.5 \cdot \frac{\mathrm{gal}}{\mathrm{min}} \\
& \mathrm{Q}_{\text {average }}:=\frac{\mathrm{Q}_{\text {High }}+\mathrm{Q}_{\text {Station }}}{2} \\
& \mathrm{~T}:=\frac{\mathrm{V}}{\mathrm{Q}_{\text {average }}}
\end{aligned}
$$$$
\text { Drain Flowrate from Highpoint, provided by Pipe-Flo }
$$$$
\text { Drain Flowrate from a Stationpoint, provided by Pipe-Flo }
$$$$
\text { Average Drain Flowrate }
$$$$
T=2.155 \cdot \mathrm{min}
$$

Time required to drain Pipe at the given Flowrate 


\section{Appendix A}

HNF-2477, Rev. 0

Page B-30 
Fluor Daniel Northwest

APPENDIX A

DESIGN ANALYSIS

client Project $W 320$

subject Transfer Line Siphon

Location M0294/200E
Calc. No. W320-27-045 App. A

Revision 0

Page No. 1 of 13

wo/Job No. E09141

Date $02 / 13 / 97$

checked 03/11/97

Revised 03/13/97
By FM Hauck zaA

By DL Stone $D C$ atro

By FM Hauck 7 f

BACKGROUND

This calculation is to develop head loss curves for the pumps in the W320 system when the transfer lines are draining following pump operation.

ultimately, the results of this calculation will be used to determine the antisyphon measures required for this system.

METHOD

The head loss curves developed in this calculation are based on data taken from "Centrifugal and Axial Flow Pumps," second edition, by AJ Stepanoff. In Table 13.3. Stepanoff uses actual pump test data for thirteen different specific speed pumps to develop values for pump operation at special conditions. (See Appendix A)

In our case we are specifically interested in the data for flow with both free and locked rotor. Using the "affinity laws" (as explained on page 26 of the text) Stepanoff's data is applied to our specific pumps to determine the head loss through the pump at different capacities.

SCOPE

This calculation develops head loss curves for 1) Lawrence Pump serial nos. 91231-1 and 91231-2. Submersible Pumps for positive and negative flow conditions and 2) Lawrence Pumps. Inc. serial nos. 91232-1 and 91232-2. Vertical Inline Slurry Pumps for negative and positive flow conditions.

SPECIFIC SPEED (Ref. Stepanoff, pg. 27, equation 2.6)

$3 \times 4 \times 13$ Submersible Pump

At the pump's BEP, the flow is $540 \mathrm{gpm}$ and the head is 114 feet when operated at $1760 \mathrm{rpm}$. $N_{s}=n \sqrt{Q} / H^{.75}$. The resulting specific speed, $N_{s}$, is 1172 .

$3 \times 3 \times 13$ Vertical Inline Pump

At the pump's BEP, the flow is $480 \mathrm{gpm}$ and the head is 448 feet when operated at $3056 \mathrm{rpm} . N_{s}=n \sqrt{Q} / H^{\cdot 75}$. The resulting specific speed. $N_{s}$, is 688 . Since this pump can be operated at variable speeds, it is important to note that "specific speed" is related to impeller geometry (hydraulics) and will remain the same as the pump speed is adjusted. 


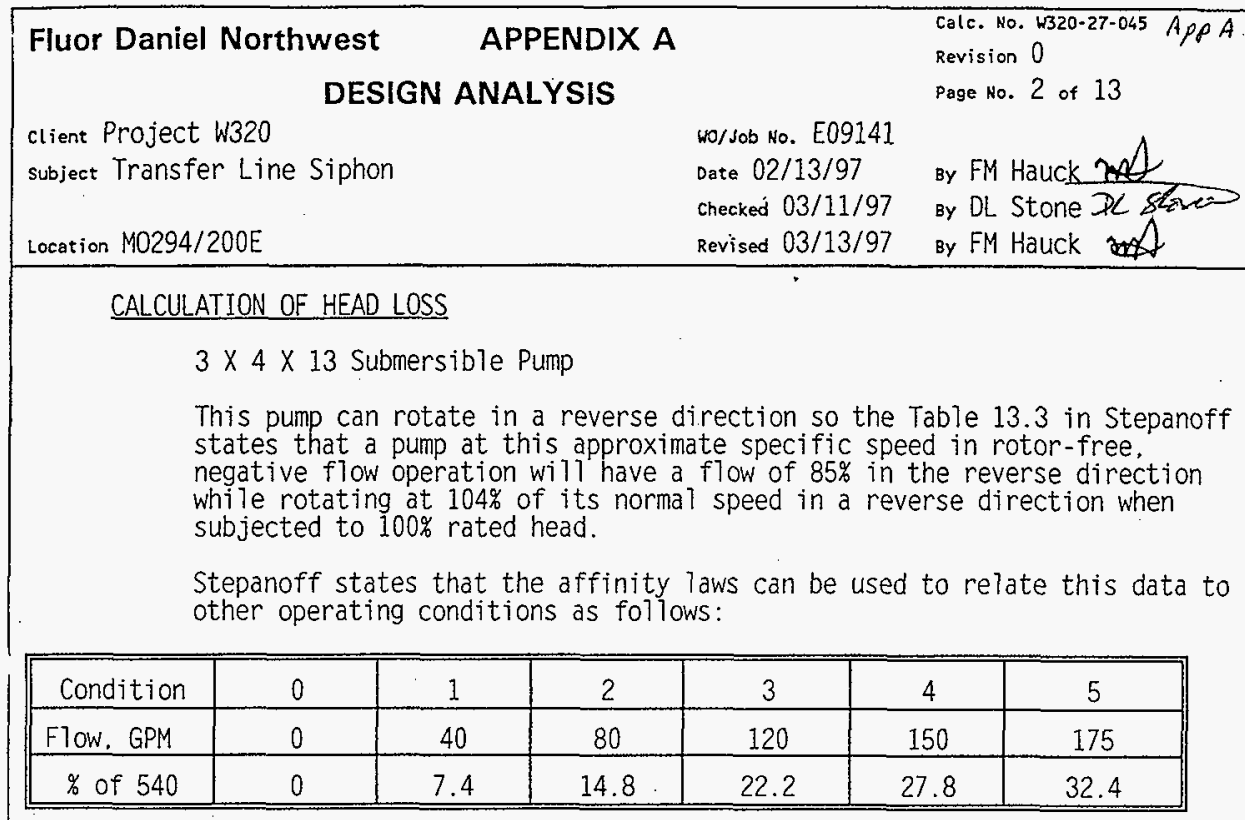

$$
H_{2}=H_{1}\left(\frac{Q_{2}}{Q_{1}}\right)^{2}
$$

CONDITION $1 \quad H_{2}=100\left(\frac{7.4}{85}\right)^{2}=0.76 \%$

$$
H_{2}=0.76 \%(114)=0.86 \mathrm{FT}
$$

CONDITION 2

CONDITION 3

CONDTTION 4

CONDITION 5

$$
\begin{aligned}
& H_{2}=100\left(\frac{14.8}{85}\right)^{2}=3.03 \% \\
& H_{2}=3.03 \%(114)=3.45 \mathrm{FT}
\end{aligned}
$$

$$
\begin{aligned}
& H_{2}=100\left(\frac{22.2}{85}\right)^{2}=6.82 \% \\
& H_{2}=6.82 \%(114)=7.78 \mathrm{FT}
\end{aligned}
$$

$$
\begin{aligned}
& H_{2}=100\left(\frac{27.8}{85}\right)^{2}=10.69 \% \\
& H_{2}=10.69 \%(114)=12.2 \mathrm{FT}
\end{aligned}
$$

$$
\begin{aligned}
& H_{2}=100\left(\frac{32.4}{85}\right)^{2}=14.5 \% \\
& H_{2}=14.5 \%(114)=16.5 \mathrm{FT}
\end{aligned}
$$

BD-6002-142 (02/97) GEF409

HNF-2477, Rev. 0

Page B-32 


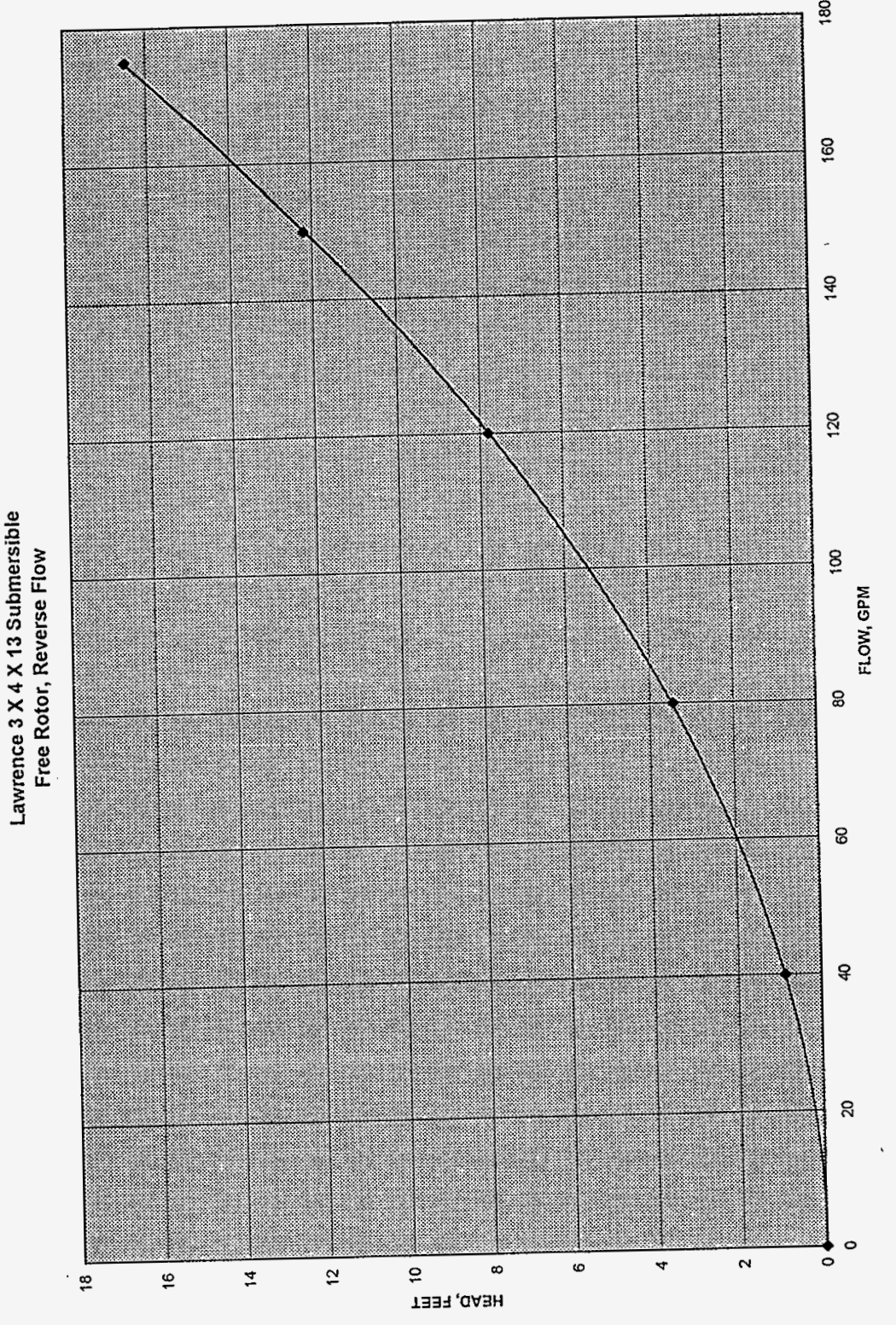

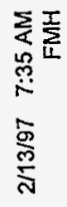


Fluor Daniel Northwest

DESIGN ANALYSIS

client Project W320

subject Transfer Line Siphon

Location MO294/200E
Calc. No. 4320-27-045 App.A

Revision 0

Page No. 4 of 13

wo/sob No. E09141

Date $02 / 13 / 97$

Checked $03 / 11 / 97$

Revised $03 / 13 / 97$
By FM Hauck

By DL Stone D $D S E D$

By FM Hauck inf

The $3 \times 4 \times 13$ - Submersible Pump can be subjected to transfer line drain down in a positive flow direction as well as negative. Again, using the information from Stepanoff and the affinity laws, a head loss vs. flow curve has been developed. Table 13.3 in Stepanoff states that with $100 \%$ flow in the positive direction there will be a head loss of $25 \%$ of the pump rated head at BEP.

$H_{2}=H_{1}\left(\frac{Q}{Q}\right)^{2}$

CONDITION $1 H_{2}=25\left(\frac{7.4}{100}\right)^{2}=0.137 \%$

$H_{2}=0.137 \%(114)=0.156 \mathrm{FT}$

CONDITION $2 H_{2}=25\left(\frac{14.8}{100}\right)^{2}=0.548 \%$

$$
H_{2}=0.548 \%(114)=0.624 \mathrm{FT}
$$

CONDITION $3 \quad H_{2}=25\left(\frac{22.2}{100}\right)^{2}=1.23 \%$

$$
H_{2}=1.23 \%(114)=1.40 F T
$$

CONDITION $4 \quad H_{2}=25\left(\frac{27.8}{100}\right)^{2}=1.93 \%$

$$
H_{2}=1.93 \%(114)=2.20 F T
$$

CONDITION $5 \quad H_{2}=25\left(\frac{32.4}{100}\right)^{2}=2.59 \%$

$H_{2}=2.59 \%(114)=2.95 \mathrm{FT}$ 


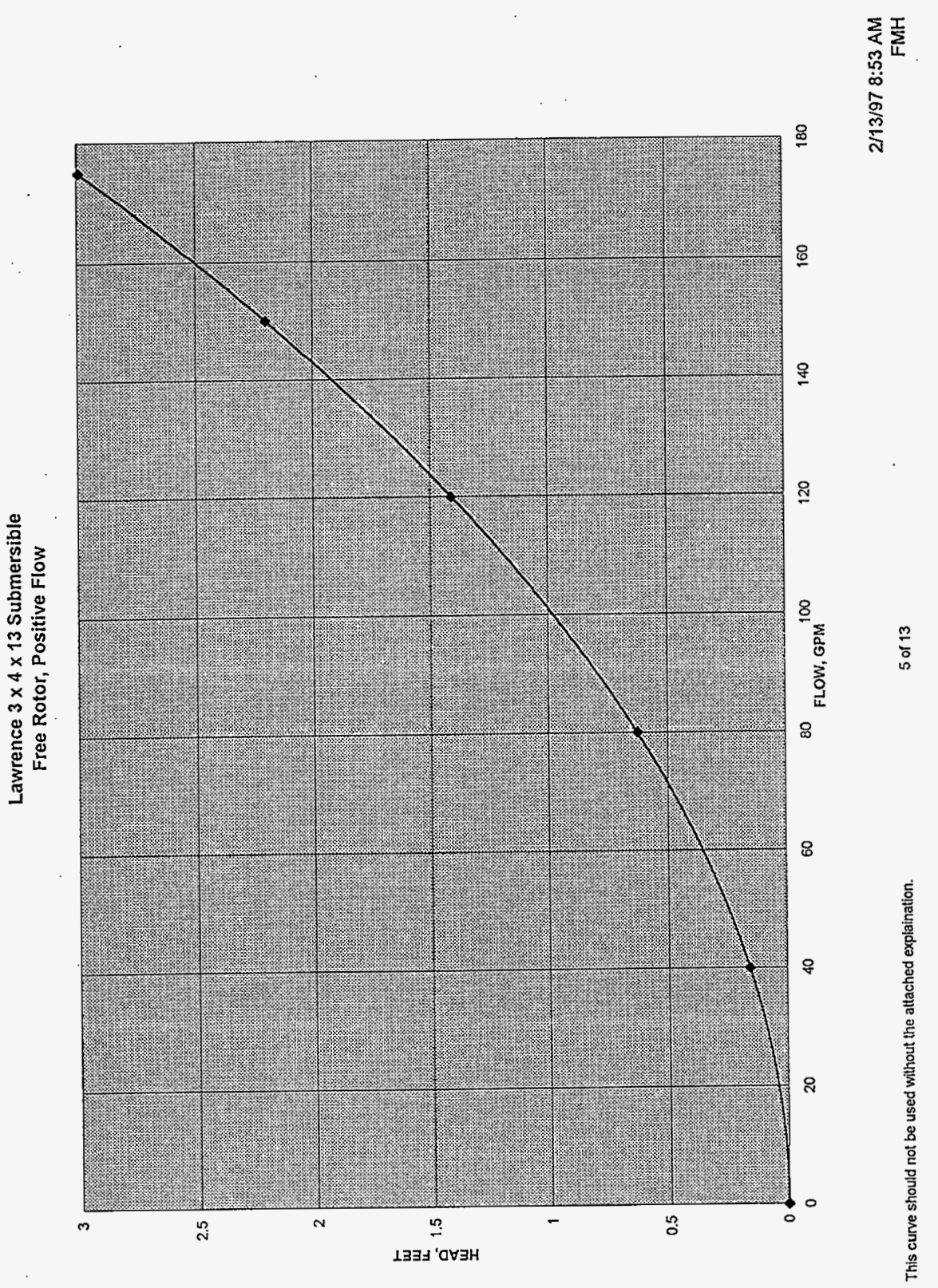

HNF-2477, Rev. 0

Page B-35 
Fluor Daniel Northwest

APPENDIX A

\section{DESIGN ANALYSIS}

client Project W320

subject Transfer Line Siphon

Location MO294/200E
Calc. Ho. k320-27-045 App A

Revision 0

Page No. 6 of 13

Wo/Job No. E09141

Date $02 / 13 / 97$

checked $03 / 11 / 97$

Revised 03/13/97
By FM Hauck

By DL Stone DLQ

By FM Hauck und

\section{CALCULATION OF HEAD LOSS--continued}

\section{$3 \times 3 \times 13$ Vertical Inline}

This pump has an anti-reverse rotation clutch on it so that during negative flow it will have a locked rotor. Since locked rotor performance data is not available for a specific speed of 688 , the values in Table 13.3 of Stepanoff for a pump specific speed of 1190 is used. This will give us a reasonable estimate of the head losses across this pump. Stepanoff states that with $100 \%$ head and $0 \%$ rotation, the negative flow will be $164 \%$.

Using the affinity laws:

\begin{tabular}{|c|c|c|c|c|c|c|}
\hline Condition & 0 & 1 & 2 & 3 & 4 & 5 \\
\hline Flow, GPM & 0 & 40 & 80 & 120 & 150 & 175 \\
\hline$\%$ of 480 & 0 & 8.3 & 16.6 & 25 & 31.2 & 36.5 \\
\hline
\end{tabular}

$$
H_{2}=H_{1}\left(\frac{Q_{2}}{Q_{n}}\right)^{2}
$$

CONDITION 1

$$
H_{2}=100\left(\frac{8.3}{164}\right)^{2}=0.26 \%
$$$$
H_{2}=0.26 \%(448)=1.15 \mathrm{FT}
$$

CONDITION 2

$$
H_{2}=100\left(\frac{16.6}{164}\right)^{2}=1.02 \%
$$$$
H_{2}=1.02 \%(448)=4.59 \mathrm{FT}
$$

CONDITION 3

$$
H_{2}=100\left(\frac{25}{164}\right)^{2}=2.32 \%
$$

$H_{2}=2.32 \%(448)=10.4 \mathrm{FT}$

CONDITION 4

$$
H_{2}=100\left(\frac{31.2}{164}\right)^{2}=3.62 \%
$$

$H_{2}=3.62 \%(448)=16.2 \mathrm{FT}$

CONDITION 5

$$
H_{2}=100\left(\frac{36.5}{164}\right)^{2}=4.95 \%
$$

$H_{2}=4.95 \%(448)=22.2 F T$ 


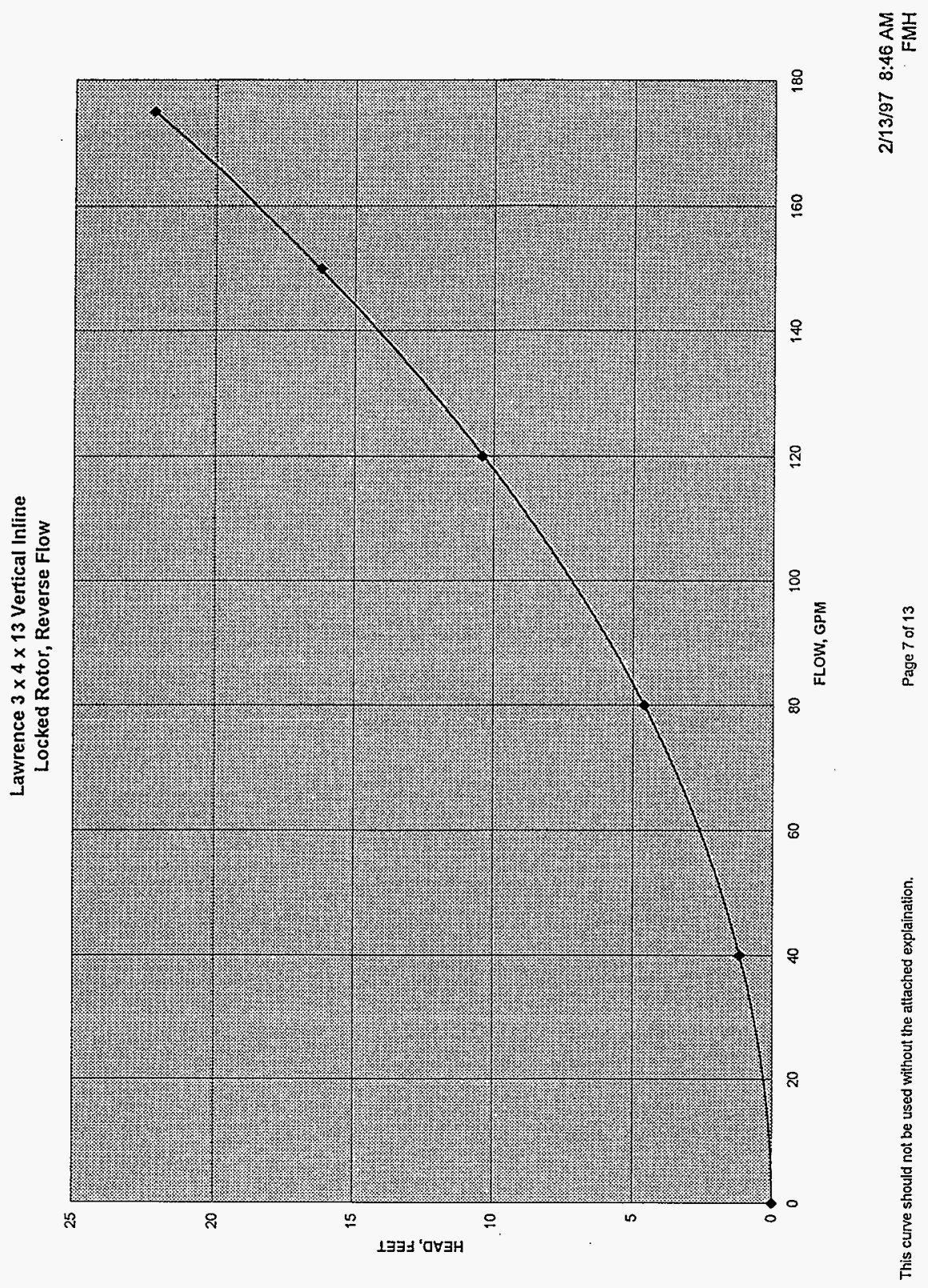




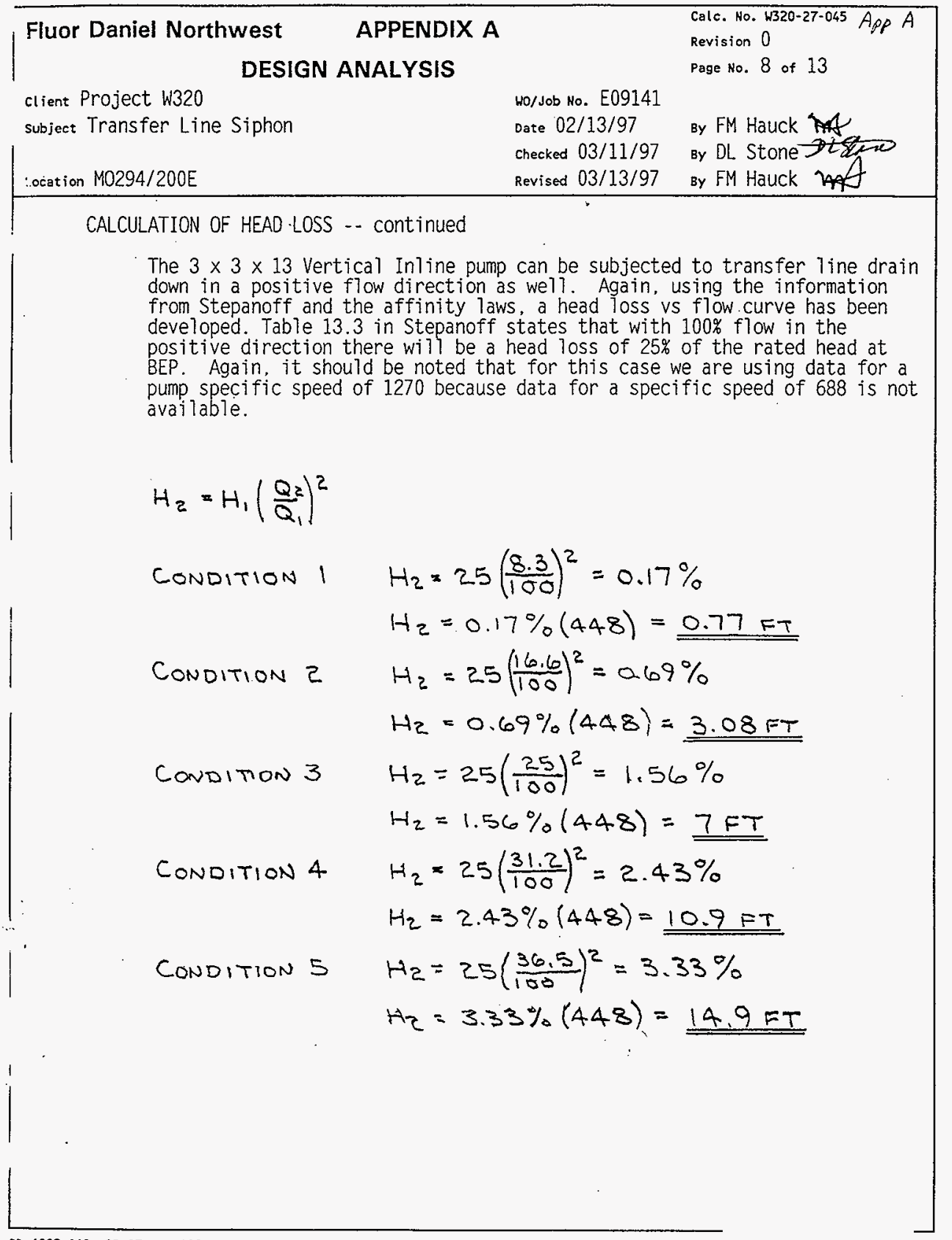

BD-6002-142 (02/97) GEF409

HNF-2477, Rev, 0

Page B-38 


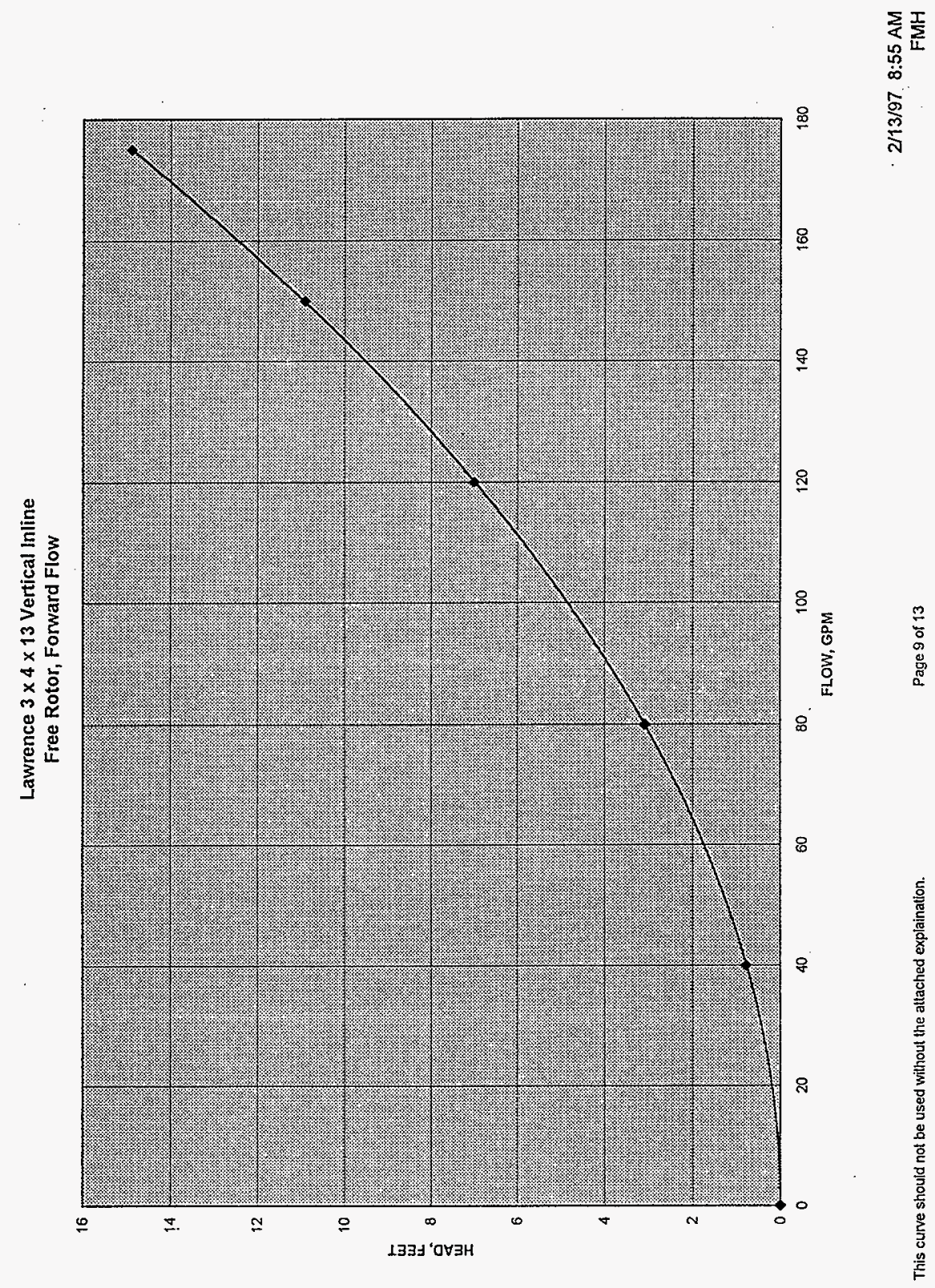

HNF-2477, Rev. 0

Page B-39 
Fluor Daniel Northwest

APPENDIX A

DESIGN ANALYSIS

client Project W320

subject Transfer Line Siphon

Location MO294/200E
Calc. No. w320-27-045 $A p p A$

Revision 0

Page No. 10 of 13

wo/sob No. E09141

Date $02 / 13 / 97$

checked 03/11/97

Revised 03/13/97
By FM Hauck

By DL Stone Ptsu

By FM Hauck A

\section{APPENDIX A}



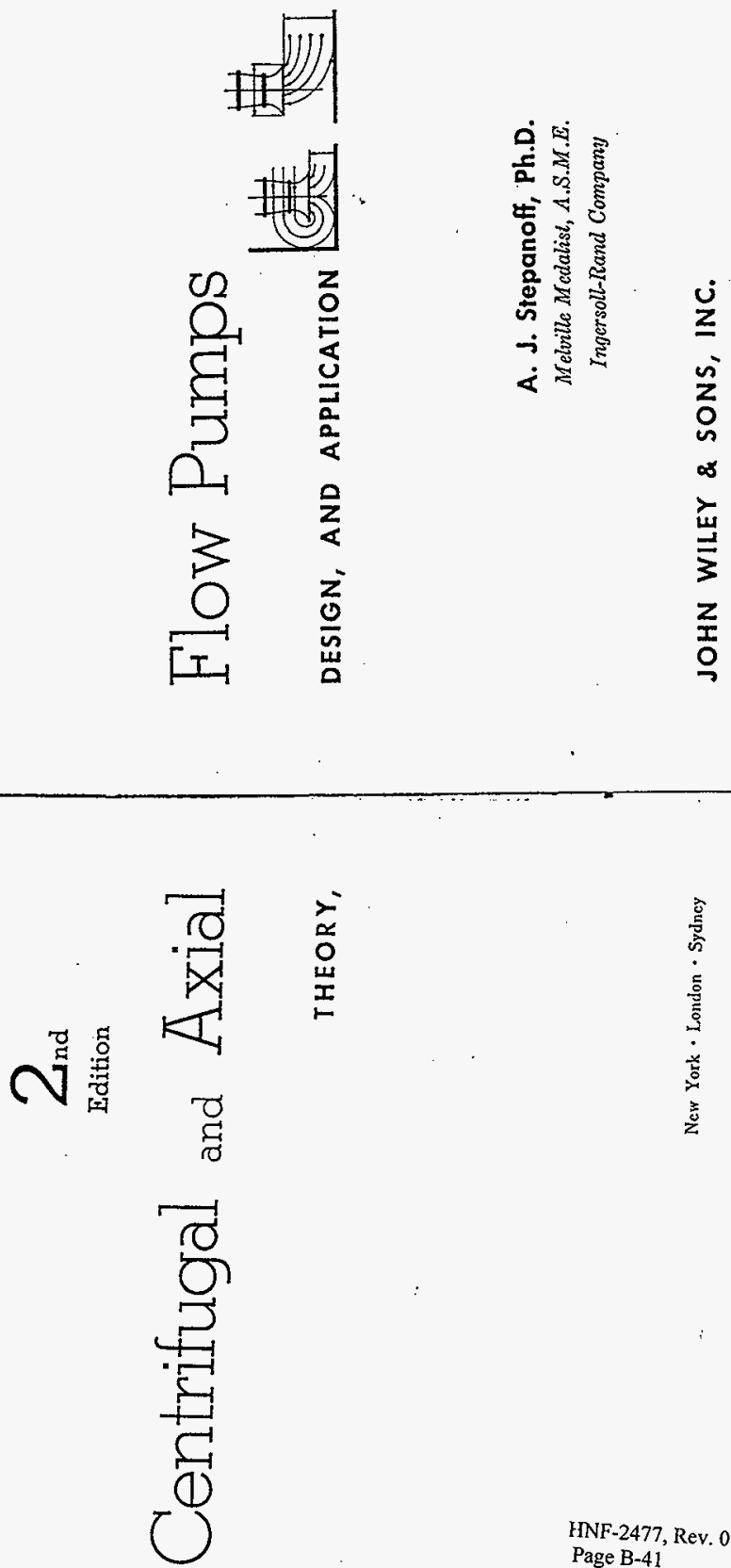

HNF-2477, Rev. 0

Page B-41 


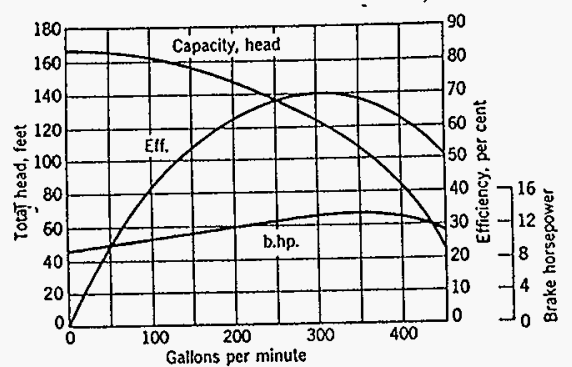

lik. 2.7. Centrifugal pump chaneteristics; 3-in. pump at 1750 rpm.

as the square of the specd, and the brake horsepower varies directiy as the cube of the speed. The cube of the speed is based on the assumption that efficiency stays constant with speed for each point. The affinity laws are cxpressed by the following equations

$$
\frac{Q_{1}}{Q_{2}}=\frac{n_{1}}{n_{2}} \quad \frac{I_{1}}{I_{2}}=\frac{n_{1}^{2}}{n_{2}^{2}} \quad \frac{(b h p)_{1}}{(b h p)_{2}}=\frac{n_{1}^{3}}{n_{2}^{3}}
$$

Figure 2.8 shows three head-capacity curves at specds $n_{1}, n_{2}$, and $n_{3}$. Points connected by the infinity laws arc called corresponding points

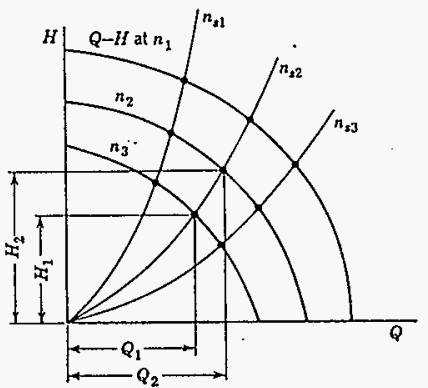

Fua. 2.8. Head and capacity variations with the speed.

and are connected by curved lines which are square parabolas. These points have the same efficiency and ure of the same specific speed.

\subsection{SPECIFIC SPEED}

In the carly stages of pump development it was customary to classify pumps according to their hydraulic-type ratios, such as a ratio of the impeller width at discharge to the impeller outside dianeter $\left(b_{2} / D_{2}\right)$. Ratios of the impeller eye diameter to the impeller outside diameter $\left(D_{1} / D_{2}\right)$ were also used for the same purpose. Camerer $f$ introduced a new characteristic to deseribe the hydraulic type of water turbines which was later applied to centrifugal pumps. It is called specific speed and is defined as

$$
n_{2}=\frac{n \sqrt{Q}}{I^{3 / 6}}
$$

where $n$ is revolutions per minute, $Q$ is capacity in gallons per minute, and $I I$ is hend in fect. The physical meaning of specific speed is: revolutions per minute to produce $1 \mathrm{gpm}$ at $1-\mathrm{ft}$ head with an impeller similar to the one under consideration but reduced in size. The physical meaning of specific speed has no practical value and the number is used as n "type" number. The specific speed as a type number is constant for all similar pumps and does not change with the speed for the same pump. Figure 2.3 shows several impellers of different specific speeds. With each specific speed are associated definite proportions of lending impeller dimensions such as $b_{2} / D_{2}$ or $D_{1} / D_{2}$.

In the study of pump performance and classification of all important design constants, spccific speed is a criterion of similarity for centrifugal pumps in the manner that Reynolds number is a criterion for pipe flow. When used as a type number, specific speed is calculated for the best efficiency point. For a multistage pump, specific speed is calculated on the basis of the head per stage. When the specific speed of a doublesuction impeller is compared with that of a single-suction impelier the capacity of the first should be divided by 2 or its specific speed should be divided by $\sqrt{2}$. All important pump design and performance characteristics are so closely connected with the specific speed that it is impossible to discuss certain features without reference to it.

From equation 2.6 it follows that, for the same head-capacity requirements, higher specific speed pumps will run at a higher speed and will be of smaller physical dimensions. Also, for the same speed and capacity, higher specific speed pumps will operate at a lower head or, for the same speed and head, $\mathfrak{a}$ higher specific speed pump will deliver a higher capacityt.

f R. Camerer, Z. ges. Turbinenwes., p. 217, 1915. 


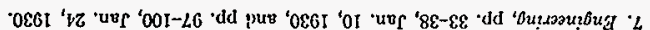

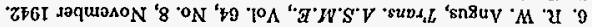

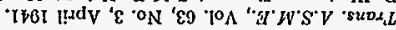

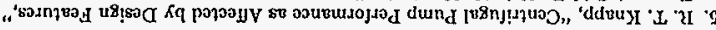
ig6t moquionon

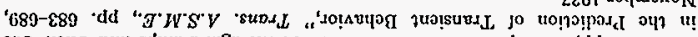
os 2 !)

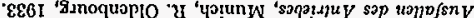
usp?

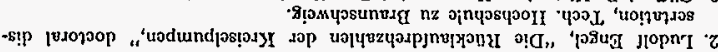
-186I 'z oun " $888-188$ 'dd

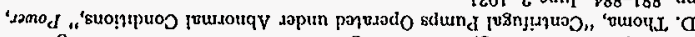

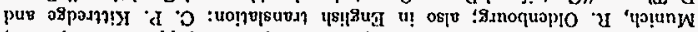

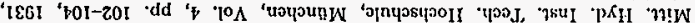

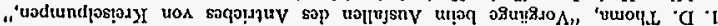

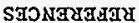

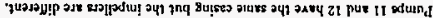

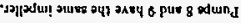

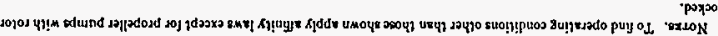

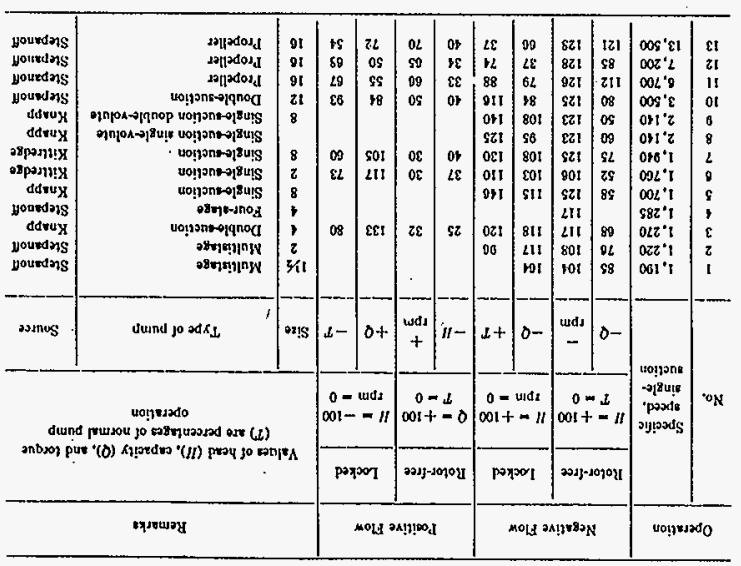

Sactad DIजIORdS

INGHAAI

I6Z SaWAd 'IVDNAIULN'ID AO SNOLLICINOD DNILVUIAO IVIDUdS

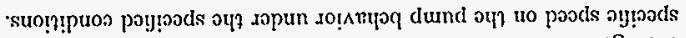
jo

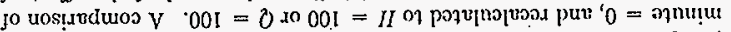
tod suonn

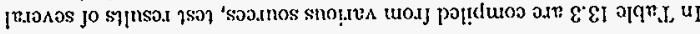

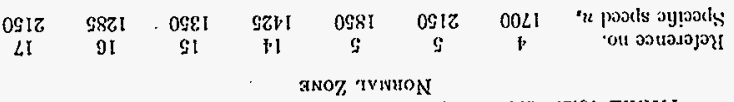

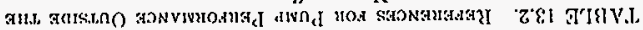

z

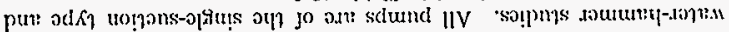

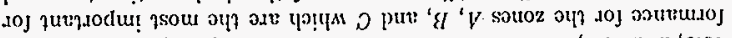

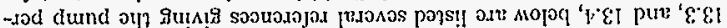

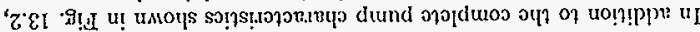

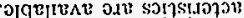

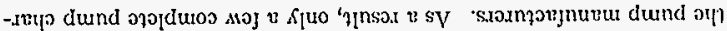

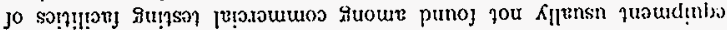

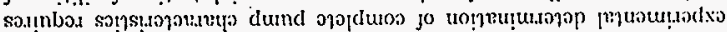

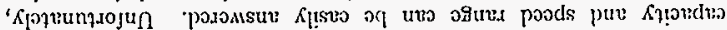

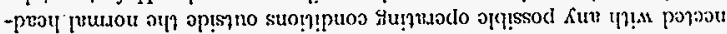

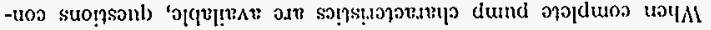

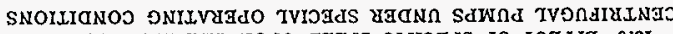

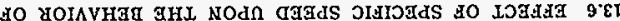

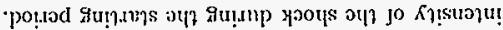

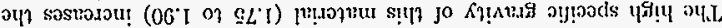

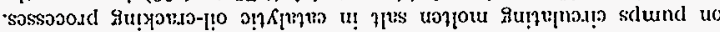

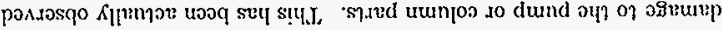

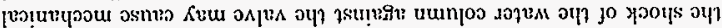

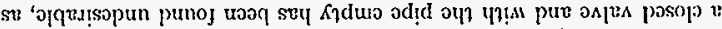

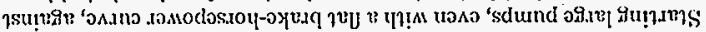

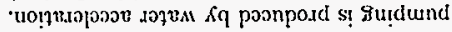

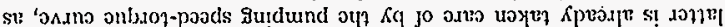

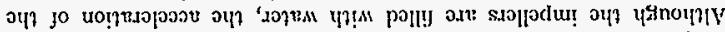

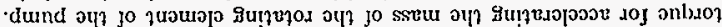

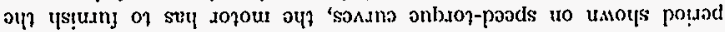

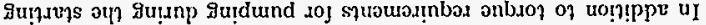

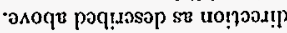

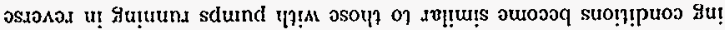


Appendix B 
FLUOR DANIEL

NORTHWEST

Client NUMATEC HANFORD COMPANY

Subject PROJECT W-320 WASTE RETRIEVAL for TANK 241-C-106

Airflow vs Pressure Drop Across Anti-Siphoning Holes

Location G TANK FARM - HANFORD 200 EAST AREA

\section{DESIGN ANALYSIS}

Wo/Job No. $\begin{array}{r}\text { E09141 } \\ \text { Date } \\ \text { Checked }\end{array}$
Revised

Calc. No. W-320-27-045, App $B$ Revision No.: 0

Page No. 1 of 5

Filename scfm-.mcd

By D.L. EVANS $\$ \mathscr{L}$

BY M.D. BROCKETT MB

By

\section{OBJECTIVE:}

The objective of this calculation is to determine the aiflow vs pressure drop across the anti-siphon holes of the W-320 Slurry and Supernate Lines.

\section{DESIGN INPUTS:}

Project W-320 Calculation W-320-27-045

Project W-320 Hydraulic Diagram - Drawing H-2-818536, Rev. 0

\section{ASSUMPTIONS:}

1. The anti-siphon holes are open.

2. The anti-siphon holes can be modeled as pressure-relieving devices as described in ANSI / API RP 520 . Ref. 1, for equipment having a maximum allowable working pressure of $15 \mathrm{psig}$ (applicable to the system during siphoning.)

\section{METHOD of ANALYSIS:}

Method used is as described in ANSI / API RP 520, Ref. 1, to determine air flow (SCFM) through anti-siphoning holes.

Calculations performed using Mathcad 6.0, MathSoft, Inc. are shown with sources noted adjacent to formulas.

\section{REFERENCES}

1. ANSI / API RP 520

2. Project W-320 Calculation W320-27-045, Appendices $E, G, I$ \& K.

\section{CONCLUSIONS}

All analyses were performed for only one anti-siphoning hole on each line. In all cases the air-flow was less than critical air flow for the available upstream pressure.

The following table shows air flows available through the anti-siphon holes at differential pressures provided by the system siphoning models at anti-siphon hole locations (Ref. 2)

$\begin{array}{llllll}\text { Slurry Line } & \begin{array}{l}\Delta \mathrm{P} \\ \text { psid }\end{array} & \begin{array}{l}\text { Air Flow } \\ \text { (SCFM) }\end{array} & \text { Supernate Line } & \begin{array}{l}\Delta \mathrm{P} \\ \text { psid }\end{array} & \begin{array}{l}\text { Air Flow } \\ \text { (SCFM) }\end{array} \\ 10 \% \text { Solids } & 6.159 & 49.33 & 0 \% \text { Solids } & 3.917 & 11.23 \\ 30 \% \text { Solids } & 6.656 & 49.54 & 10 \% \text { Solids } & 4.368 & 11.58\end{array}$


FLUOR DANIEL

NORTHWEST

Client NUMATEC HANFORD COMPANY

Subject PROJECT W-320 WASTE RETRIEVAL. for TANK 241-C-106

Pipe Drainflow and Anti-Siphon Sizing for Transfer Lines

Location C TANK FARM - HANFORD

\section{DESIGN ANALYSIS}

WO/Job No. E09141

Date $\quad 3 / 5 / 97$

Checked

Revised
Calc. No. W-320-27-045, App

Revision No.: 0

Page No. 2 of 5

Filename siphonltext.mgd

By D.L. EVANS $\nsucceq \mathscr{L} \mathcal{E}$

BY M.D. BROCKETT MB

\section{CALCULATIONS}

\section{Check for Critical Flow}

Critical throat pressure is calculated for the most conservative case, only.

Maximum differential pressure from the four siphon models was for the $30 \%$ Solids Slurry line.

$\mathrm{P}_{1}=14.4 \mathrm{psia} \quad$ Atmospheric (Dome Air Space) Pressure - Atmospheric at Elev. $640 \mathrm{ft}$

$\Delta \mathrm{P}=6.656$ psi Maximum Pressure Drop across Anti-Siphon Hole during Siphon Flow, in psig

$\mathrm{P}_{2}:=\mathrm{P}_{1}-\Delta \mathrm{P} \quad \mathrm{P}_{2}=7.7$ psia Pipe internal pressure at Anti-Siphon Hole during Siphon Flow, in psia

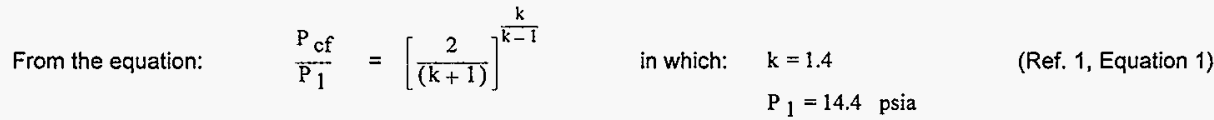

$P_{\text {cf }}:=P_{1} \cdot\left[\frac{2}{(k+1)}\right]^{\frac{k}{k-1}} \quad P_{c f}=7.6 \quad$ psia $\quad$ Critical Flow Throat Pressure

(Ref. 1, Sec. 4.3.1)

Note: $P_{2}=7.7$ psia $>P_{c f}=7.6 \quad$ psia $\quad$ Since the downstream pressure, $P_{2}$, exceeds the Critical Flow Pressure, $P_{c f}$, Subcritical Flow occurs.

\section{Subcritical Flow Equation for Air Flow through One Anti-Siphon Hole}

$10 \%$ Solids Siurry Line - 1/2" Hole Diameter (Calculation shown for $10 \%$ Solids Slurry Line case.

All cases are tabulated and graphed.)

From the equation: $\quad \mathrm{A}=\frac{\mathrm{V}}{4645.2 \cdot \mathrm{F}_{2} \cdot \mathrm{K}_{\mathrm{d}}} \cdot \sqrt{\frac{\mathrm{Z} \cdot \mathrm{T} \cdot \mathrm{M}}{\mathrm{P}_{1} \cdot\left(\mathrm{P}_{1}-\mathrm{P}_{2}\right)}} \quad \begin{aligned} & \text { Effective required discharge } \\ & \text { area of the Anti-Siphon hole }\end{aligned} \begin{aligned} & \text { Ref. } 1, \mathrm{Pgs} 28 \& 29 \text {, } \\ & \text { Equation } 6\end{aligned}$

Solving for air flow:

$$
\begin{aligned}
& \mathrm{V}=4645.2 \cdot \mathrm{K}_{\mathrm{d}} \cdot \mathrm{A} \cdot \frac{\mathrm{F}_{2}}{\sqrt{\frac{\mathrm{Z} \cdot \mathrm{T} \cdot \mathrm{M}}{\mathrm{P}_{1} \cdot\left(\mathrm{P}_{1}-\mathrm{P}_{2}\right)}}}=4645.2 \cdot \mathrm{K}_{\mathrm{d}} \cdot \mathrm{A} \cdot \frac{\mathrm{F}_{2} \cdot \sqrt{\mathrm{P}_{1} \cdot\left(\mathrm{P}_{1}-\mathrm{P}_{2}\right)}}{\sqrt{\mathrm{Z} \cdot \mathrm{T} \cdot \mathrm{M}}} \\
& \mathrm{V}:=\left(\frac{4645.2 \cdot \mathrm{K}_{\mathrm{d}} \cdot \mathrm{A}}{\sqrt{\mathrm{Z} \cdot \mathrm{T} \cdot \mathrm{M}}}\right) \cdot\left[\mathrm{F}_{2} \cdot \sqrt{\mathrm{P}_{1} \cdot\left(\mathrm{P}_{1}-\mathrm{P}_{2}\right)}\right] \quad \mathrm{V}=49.5 \mathrm{SCFM} \quad \begin{array}{l}
\text { Required flow through a Single } \\
\text { Anti-Siphon Hole }
\end{array}
\end{aligned}
$$


FLUOR DANIEL

NORTHWEST

Client NUMATEC HANFORD COMPANY

Subject PROJECT W-320 WASTE RETRIEVAL tor TANK 24i-C-106

Pipe Drainflow and Anti-Siphon Sizing for Transfer Lines

Location C TANK FARM - HANFORD 200 EAST AREA

\section{DESIGN ANALYSIS}

Wo/Job No. E09141

Date $3 / 5 / 97$

Checked

Revised
Calc. No. W-320-27-045, App. B Revision No.: 0

Page No. 3 of 5

Filename siphonltext.mgd

By D.L. EVANS $\$ \notin \xi$

By

By
In which: $k=1.4$

$\Upsilon_{\text {Farenheit }}=80.0 \mathrm{~F}$

$T:=T_{\text {Farenheit }}+460$

$M=29.0$

$Z=1.0$

$\mathrm{K}_{\mathrm{d}}=0.975$

$r:=\frac{P_{2}}{P_{1}} \quad r=0.5$

$d=0.5$ in

$A:=\frac{\pi \cdot(d)^{2}}{4} \quad A=0.2 \quad$ in $^{2}$

$F_{2}:=\sqrt{\left(\frac{k}{k-1}\right) \cdot(r)^{\frac{2}{k}} \cdot\left[\frac{1-r^{\frac{(k-1)}{k}}}{1-r}\right]}$
Ratio of Specific Heats (Air)

Temperature in degrees Farenheit

Temperature in degrees Rankine

Molecular weight of air

Compressibility factor for the deviation of the actual gas from a perfect gas

Effective coefficient of discharge

Ratio of backpressure to upstream relieving pressure (Pipe internal pressure to Dome Space pressure)

Diameter of siphon holes

Actual Discharge Area of siphon holes

$F_{2}=0.7 \quad$ Coefficient of subcritical flow through siphon holes

Collecting variables and regrouping, this equation can be simplified to:

$$
V:=(4645.2) \cdot\left(K_{d}\right) \cdot\left(P_{1}\right) \cdot(A) \cdot \sqrt{\frac{k}{M \cdot T \cdot Z \cdot(k-1)} \cdot\left[\left(\frac{P_{2}}{P_{1}}\right)^{\frac{2}{k}}-\left(\frac{P_{2}}{P_{1}}\right)^{\frac{k+1}{k}}\right]} \quad V=49.5 \quad \text { SCFM }
$$


FLUOR DANIEL

\section{NORTHWEST}

\section{DESIGN ANALYSIS}

WO/Job No. E09141

Date $\quad 3 / 5 / 97$

Checked

Revised
Calc. No. W-320-27-045, App. B Revision No.: 0

Page No. 4 of 5

Filename siphonltext.med

By D.L. EVANS $\$ \varphi$

By

By

Location C TANK FARM - HANFORD 200 EAST AREA

Slurry Line - 1/2" Hole Diameter

$\mathrm{d}:=\frac{1}{2}$ in $\quad \mathrm{A}:=\frac{\pi \cdot(\mathrm{d})^{2}}{4} \quad \mathrm{~A}=0.196$ in $^{2} \quad$ Actual Discharge Area of a single siphon hole

$\Delta P_{i}:=\quad$ Differential pressure at Anti-Siphon Hole

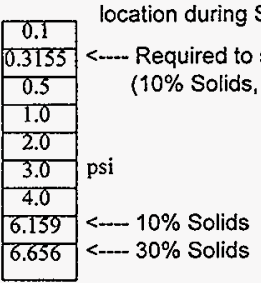

(Ref. 2, Pg.5)

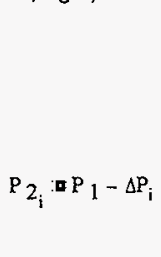

Pipe internal pressure at

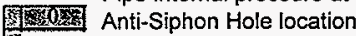

0.00

14.30

14.08

13.90

13.40

$\mathrm{P}_{2}=\frac{9}{11.40}$ psia

10.40

$8 \overline{8.24}<-10 \%$ Solids

19.74 <.-- $30 \%$ Solids
$V_{i}:=(4645.2) \cdot\left(K_{d}\right) \cdot\left(P_{1}\right) \cdot(A) \cdot \sqrt{\frac{k}{M \cdot T \cdot Z \cdot(k-1)} \cdot\left(\frac{P_{2}}{P_{1}}\right)^{\frac{2}{k}}-\left(\frac{P_{2}}{P_{1}}\right)^{\frac{k+1}{k}}}$

Air flow through One Anti-Siphon Hole

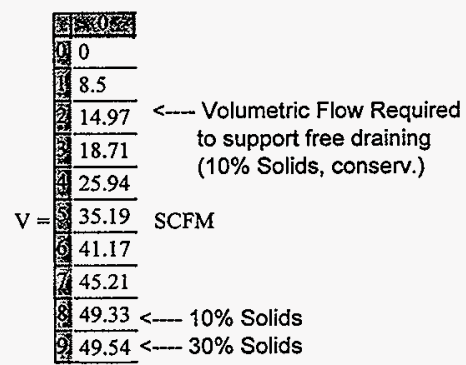




\section{FLUOR DANIEL}

NORTHWEST

Cllent NUMATEC HANFORD COMPANY

Subject PROJECT W-320 WASTE RETRIEVAL for TANK 241-C-106

Pipe Drainflow and Anti-Siphon Sizing for Transfer Lines

Location C TANK FARM - HANFORD

200 EAST AREA

\section{DESIGN ANALYSIS}

WO/Job No. E09141

Date $3 / 5 / 97$

Checked

Revised
Calc. No. W-320-27-045, App $B$ Revision No.: 0

Page No. 5 of 5

Filename siphonitext,med

By D.L. EVANS DS 2

BY M.D. BROCKETT (MP)

By

\section{Sluice (Supernate) Line - 1/4" Hole Diameter}
$\mathrm{d}:=\frac{1}{4}$ in
$A:=\frac{\pi \cdot(d)^{2}}{4}$
$\mathrm{A}=0.049$ in $^{2}$
Actual Discharge Area of a single siphon hole

$\Delta \mathrm{P}_{\mathrm{i}}:=$ Differential pressure at Anti-Siphon Hole

location during Siphon Flow, in psia (Ref. 2, Pg. 5)
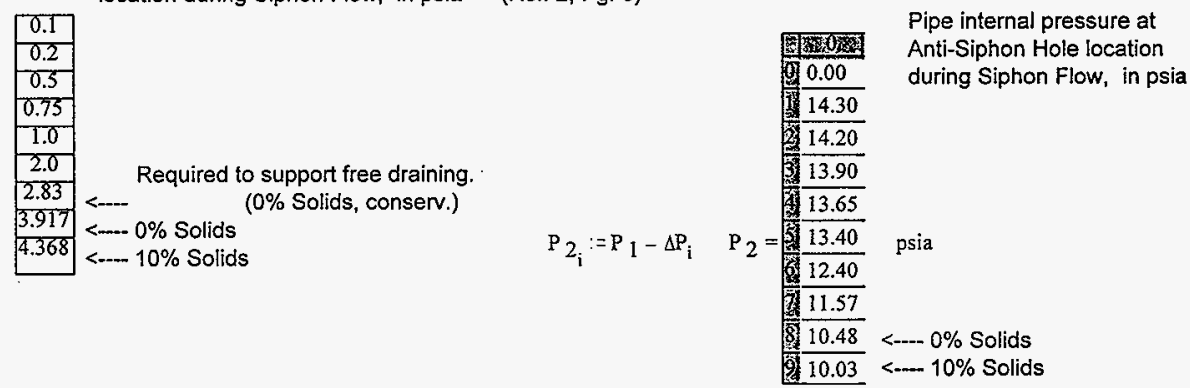


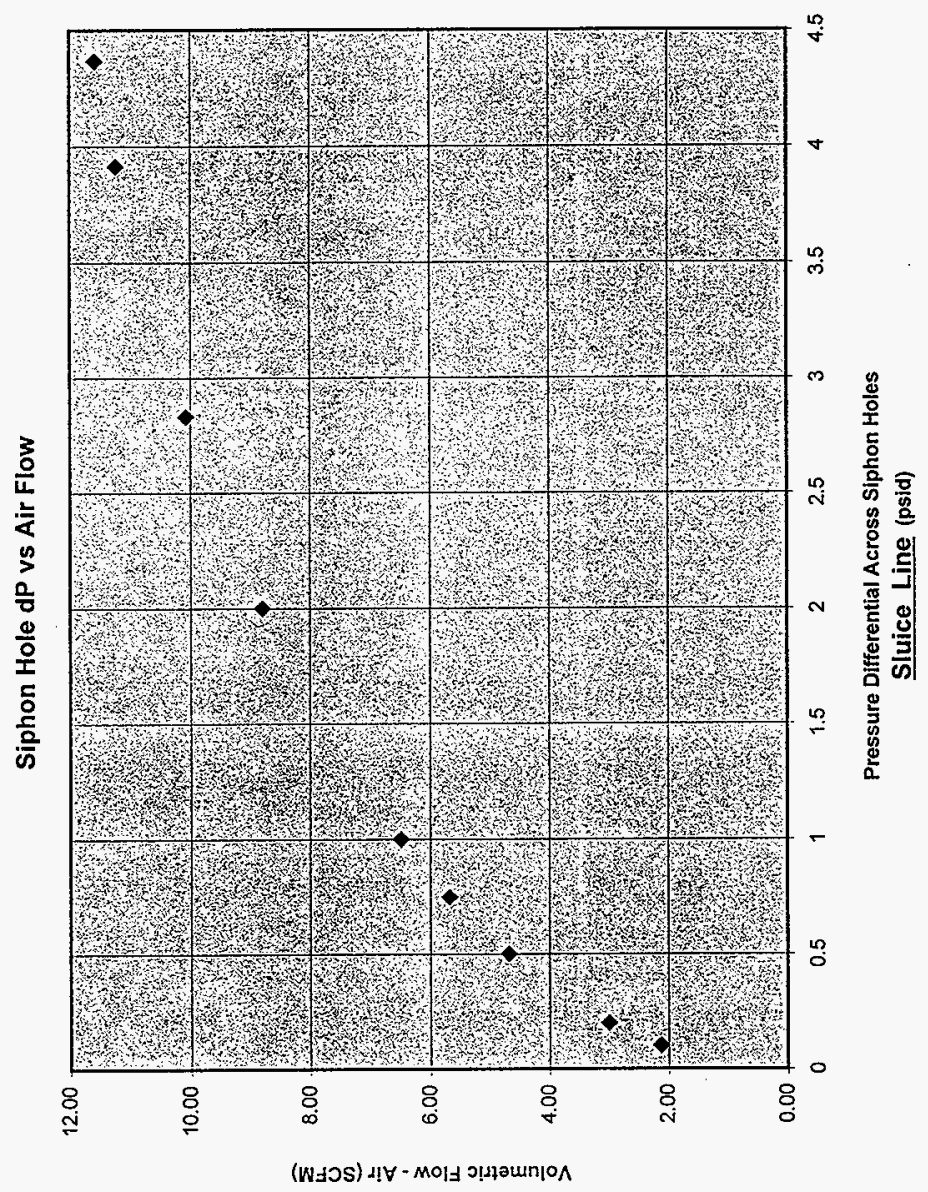

0
5
5
-5
5
5
5 


\begin{tabular}{|c|c|}
\hline$\Delta P$ & $V$ \\
\hline 0.1 & 8.50 \\
0.3155 & 14.97 \\
0.5 & 18.71 \\
1 & 25.94 \\
2 & 35.19 \\
3 & 41.17 \\
4 & 45.21 \\
5 & 47.82 \\
6.159 & 49.33 \\
6.656 & 49.54 \\
& \\
\hline
\end{tabular}

Siphon Hole dP vs Air Flow

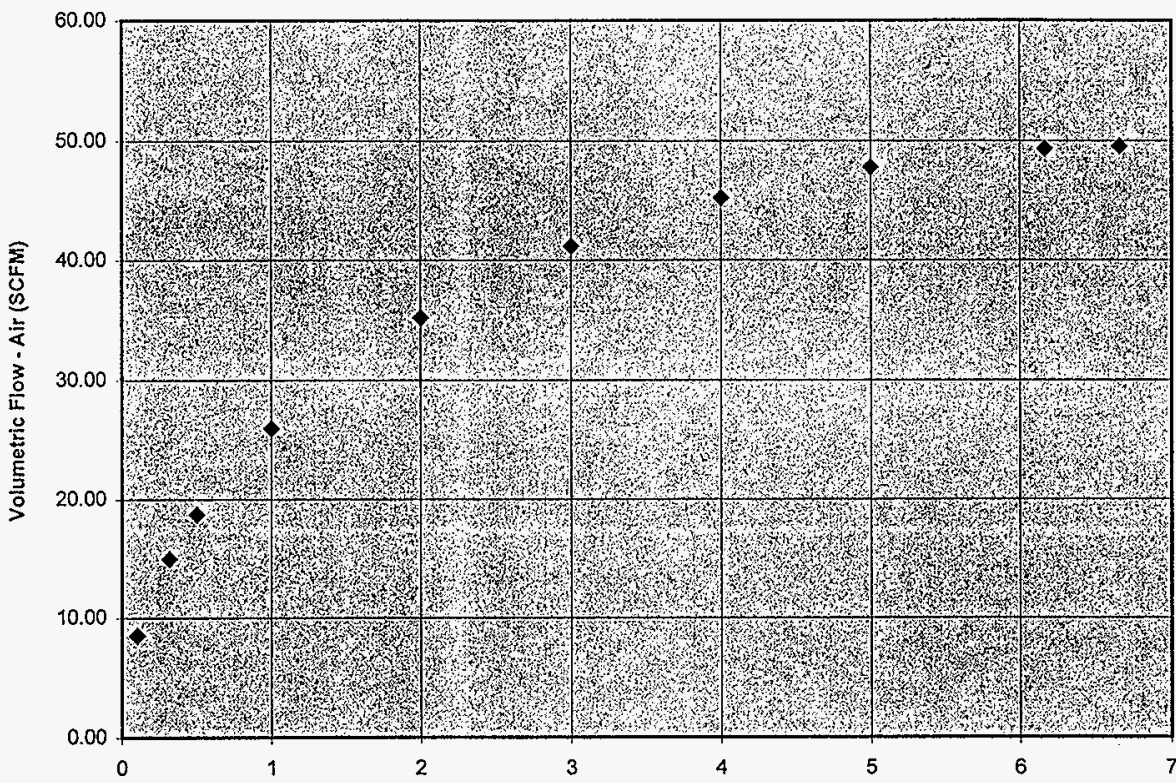

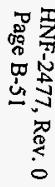

Pressure Differential Across Siphon Holes

Slurry Line (psid)

Alch. 2, App.B 


\section{Appendix C}

HNF-2477, Rev. 0

Page B-52 


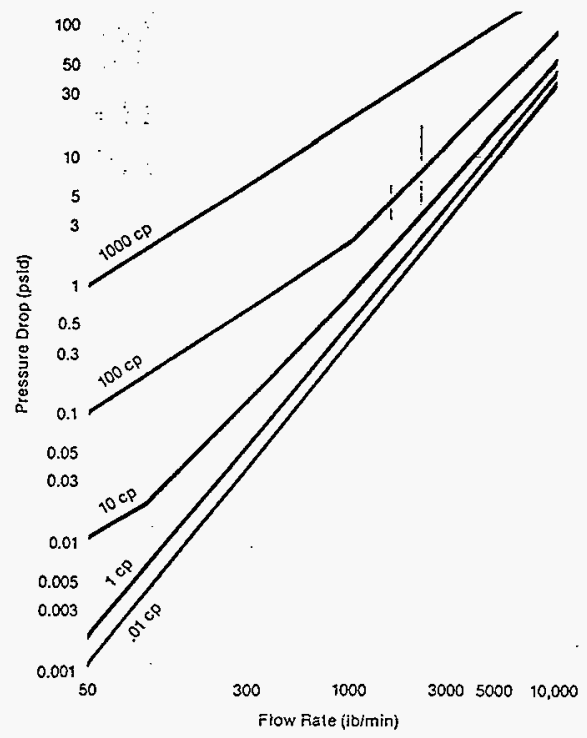

Finding pressure drop of process fluids with a viscosity near 1 centipoise $(\mu)$

1. The pressure drop charts shown above have several curves, which represent different viscosity $(\mu)$ values. For fluids with a viscosity similar to water, use the curve labeled $\mu=1.0$.

2. Locate the point on the English units or Metric units graph where the vertical line representing the desired flow rate intersects the curve labeled $\mu=1.0$.

3. From that point, locate the nearest horizontal line, then refer to the left side of the graph, which indicates pressure drop (in psid or bar) at the desired flow rate.

4. Divide the pressure drop indicated on the graph by the specific gravity $(S)$ of the process fluid relative to water:

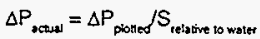

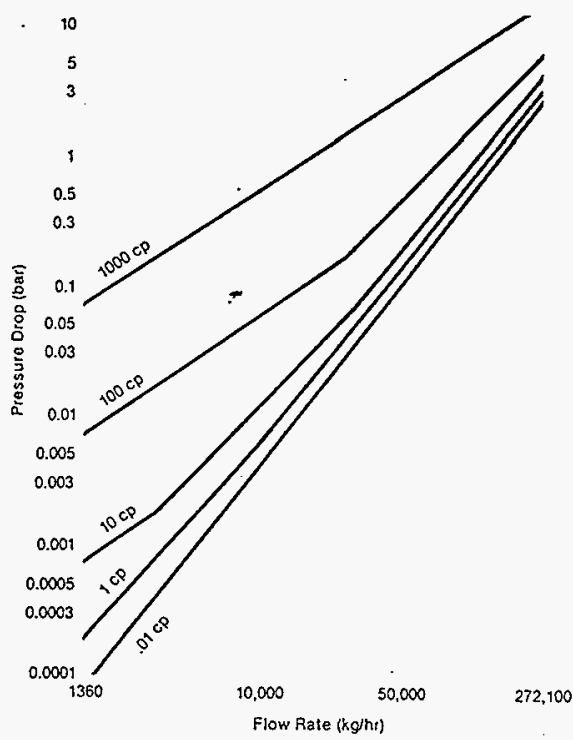

Finding pressure drop of process fluids with a viscosity above 1 centipoise $(\mu)$

1. The pressure drop charts shown above have several curves, which represent different viscosity $(\mu)$ values. Use method $a$ or $b$, below, to find the process fluid viscosity $\left(f_{\text {visoxiny }}\right)$.

a. For fluids with a viscosity between any two values plotled on the English units or Metric units graph, interpolate the approximate $f_{\text {mocosiny }}$ location.

b. For fluids with a viscosity above the highest value plotted on the graph, find the ratio of actual viscosity to plotted viscosity:

$$
f_{\text {visosion }}=\mu_{\text {saves }} / \mu_{\text {ploted }}
$$

2. Multiply the pressure drop indicated on the left side of the graph by the $f_{\text {viscosin }}$ value from step 1:

$$
\Delta P=\Delta P_{\text {plocked }} \times f_{\text {viscesing }}
$$

3. To find the actual pressure drop, divide the $\triangle P$ from step 2 by the specific gravity (S) of the process fluid relative to water:

$$
\Delta P_{\text {sctum }}=\Delta P / S_{\text {refative } 10 \text { maleer }}
$$




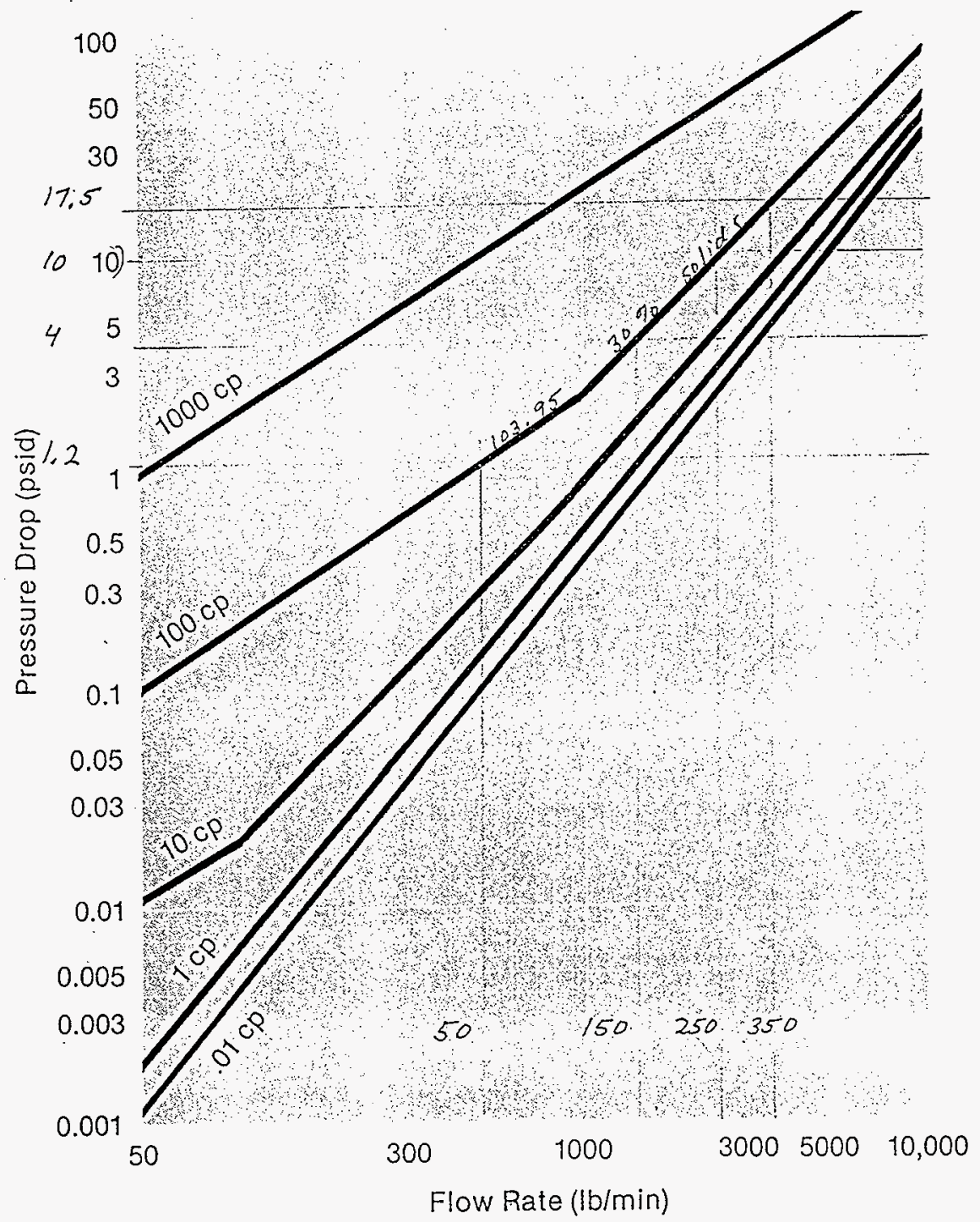

CMF300 flow rate vs. pressure drop 


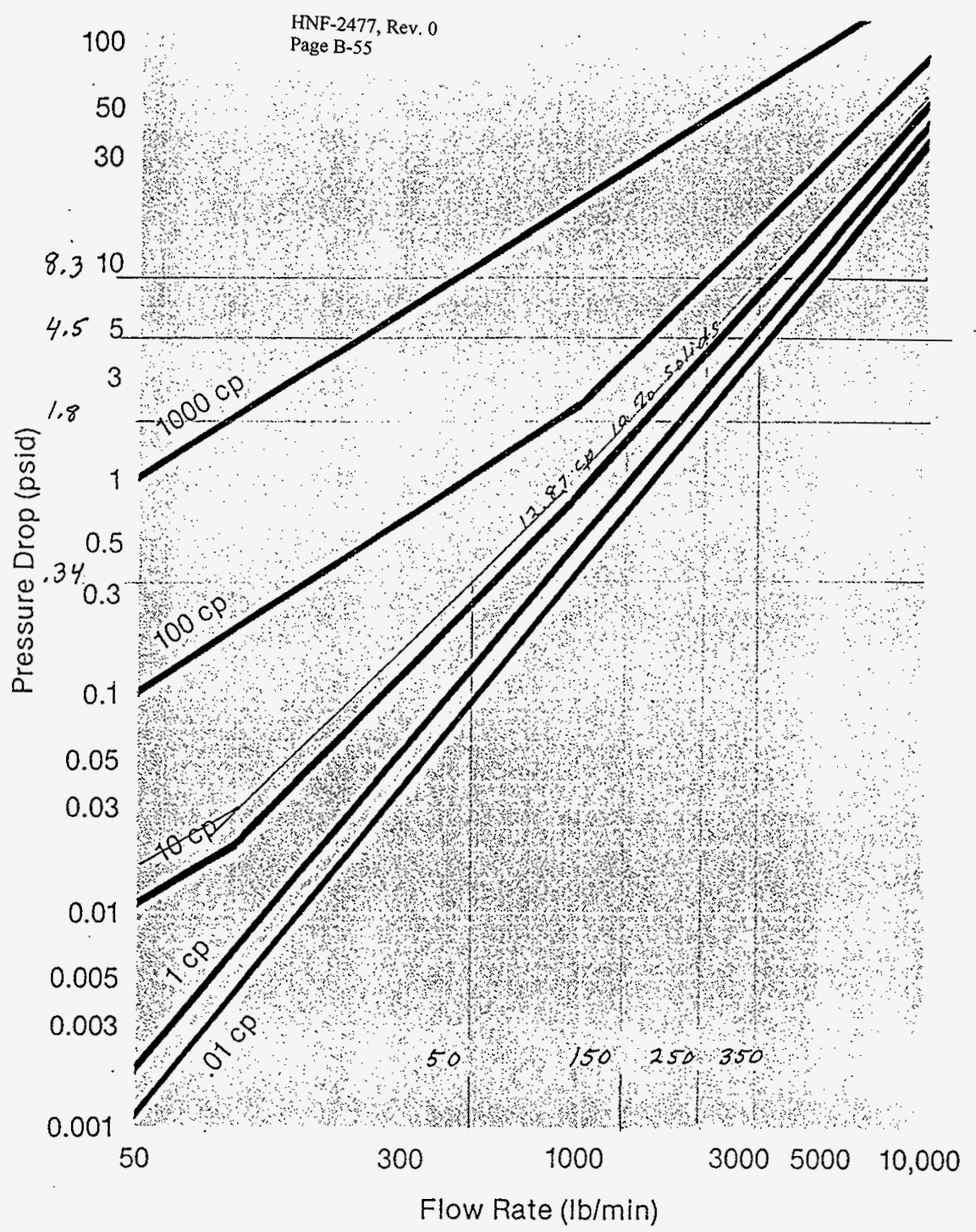

\section{CMF300 flow rate vs. pressure drop}


Appendix D 
Station Points Table

\begin{tabular}{|c|c|c|c|c|c|}
\hline Slurry Line & & Station Point & $\begin{array}{l}\text { Station Poin } \\
\text { Elevation }\end{array}$ & Length of Pipe & $90 \mathrm{deg}$ Els \\
\hline Node $\sim \mathrm{N}--3$ & & 1610.29 & 641.42 & & 6 \\
\hline & Pipe 3.1 & & & 410.3 & \\
\hline Node $\sim \mathrm{N}-\mathrm{-3.1}$ & & 1200.00 & 650.39 & & 4 \\
\hline & Pipe 3.2 & & & 468.1 & \\
\hline Node $\sim N-3.2$ & & 731.88 & 661.63 & & 11 \\
\hline & Pipe 3.3 & & & 843.2 & \\
\hline \multirow[t]{2}{*}{ Node $\sim \mathrm{N}-3.3$} & & -111.35 & 675.46 & & \\
\hline & & & & 1721.6 & ine Length \\
\hline
\end{tabular}

Supernate Line

Station Point Station Point Elevation Length of Pipe $90 \mathrm{deg}$ Els

Node $\sim \mathrm{N}--7$

$1628.74 \quad 641.42$

Pipe 4.3

Node $\sim N-6$

Pipe 4.2

Node $\sim \mathrm{N}-5$

Pipe 4.1

Node $\sim \mathrm{N}-\mathrm{-4}$

\begin{tabular}{lll}
1200.00 & 650.39 & 428.7 \\
731.88 & 661.63 & 468.1 \\
& & 822.8 \\
-90.91 & 677.11 & \\
\hline
\end{tabular}

1719.7

Line Length 


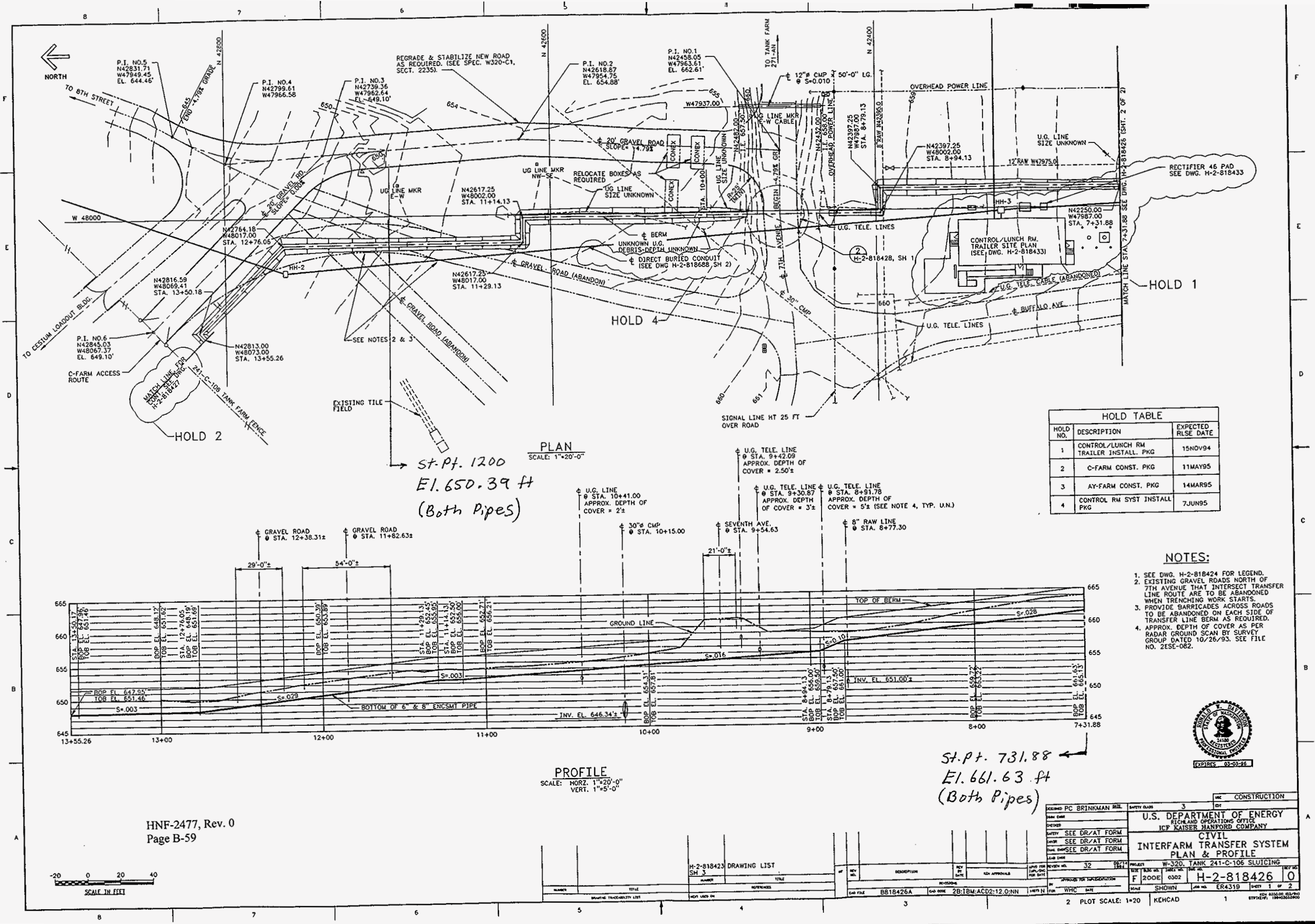




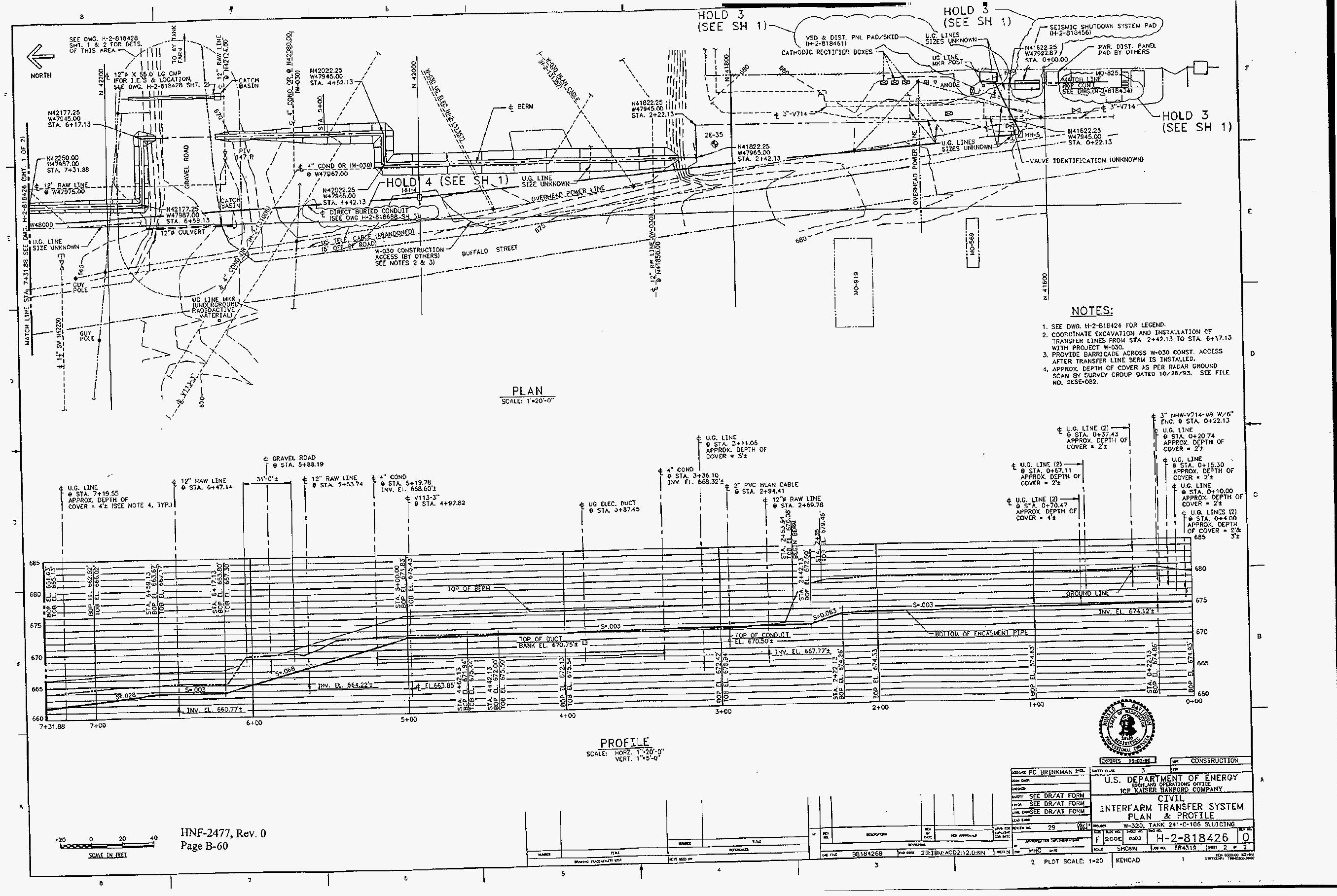




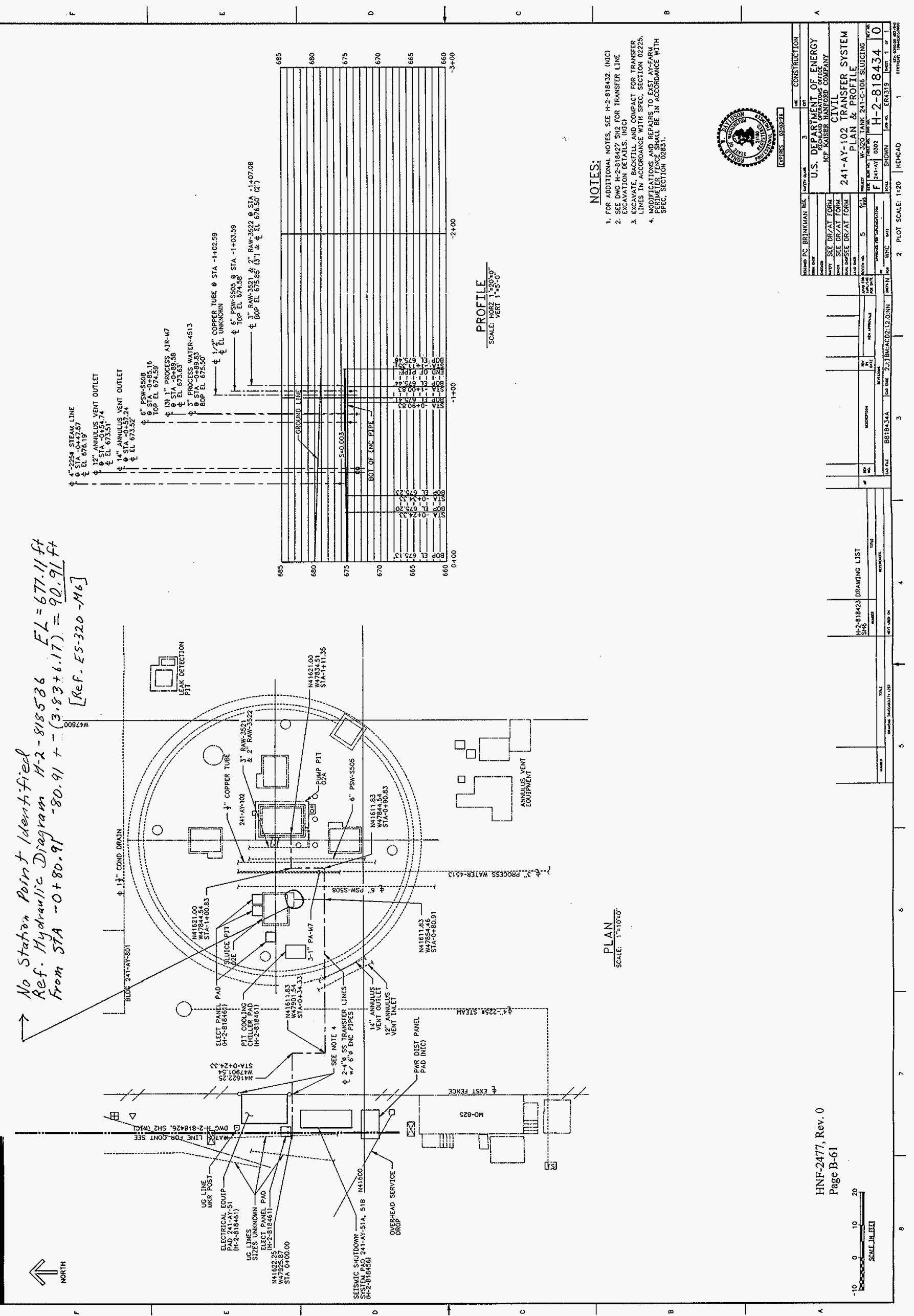




\section{Appendix E}




\begin{tabular}{|c|c|c|}
\hline 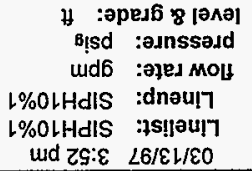 & 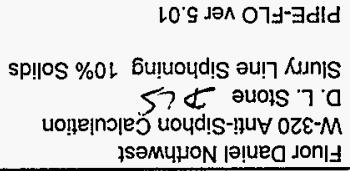 & 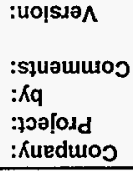 \\
\hline
\end{tabular}

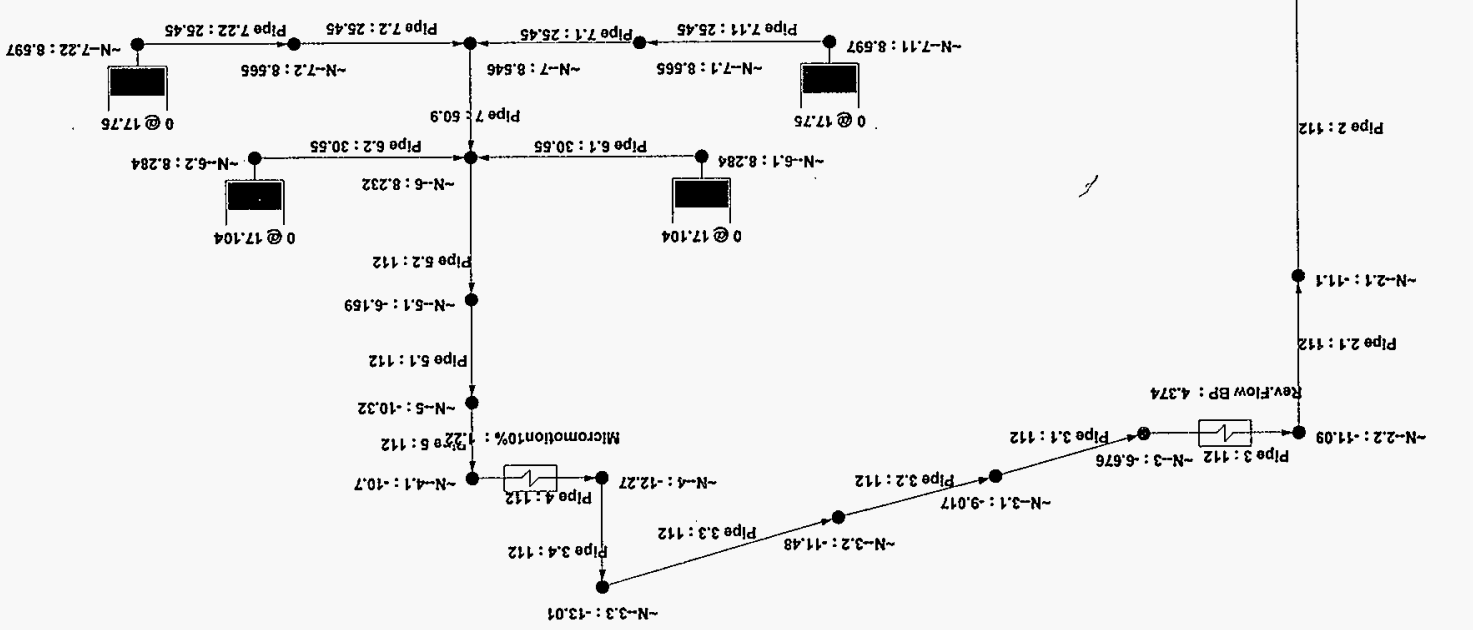


Company: Fluor Daniel Northwest

Project: W-320 Anti-Siphon Calculation

by: D. L. Stone
03/13/97 $3: 52 \mathrm{pm}$

Lineup: SIPH $10 \% 1$

rev: 03/13/97 $3: 50 \mathrm{pm}$

System: SIPH $10 \% 1$

rev: 03/13/97 $3: 48 \mathrm{pm}$

Deviation: $0.000354 \%$

after: 9 iterations

Slurry Line - Siphon - 10\% Solids - configuration 1

Volumetric flow rates require constant fluid properties in all pipelines. Fluid properties in the first specification were used in this calculation.

LINEUP SUMMARIES

PIPELINE

Pipe 0

Pipe 6.1

Pipe 6.2

Pipe 7.11

Pipe 7.22
PRESSURE SOURCE

$\sim N-0$

$\sim N-6.1$

$\sim N-6.2$

$\sim N--7.11$

$\sim \mathrm{N}-\mathrm{-7.22}$
SET psi g

0

0

0

0

0

Flows IN: $112 \mathrm{gpm}$

Flows OUT: $112 \mathrm{gpm}$

NET FLOWS: $0 \mathrm{gpm}$
LEVEL

$\mathrm{ft}$

0

17.1

17.1

17.75

17.75

$\ll 25.45$

HNF-2477, Rev. 0

Page B-64 
NODE

$\sim \mathrm{N}-\mathrm{O}$

$\sim N-1$

$\sim \mathrm{N}-2$

$\sim \mathrm{N}-2.1$

$\sim \mathrm{N}-2.2$

$\sim \mathrm{N}-3$

$\sim \mathrm{N}-3.1$

$\sim \mathrm{N}-3.2$

$\sim \mathrm{N}-3.3$

$\sim \mathrm{N}-4$

$\sim N-4.1$

$\sim \mathrm{N}-\mathrm{-5}$

$\sim N-5.1$

$\sim \mathrm{N}-6$

$\sim \mathrm{N}-6.1$

$\sim \mathrm{N}-6.2$

$\sim \mathrm{N}-7$

$\sim N-7.1$

$\sim \mathrm{N}-\mathrm{-7.11}$

$\sim \mathrm{N}-7.2$

$\sim N-7.22$

ELEVATION
$\mathrm{ft}$
608
608.443
609.838
639.107
639.107
639.461
650.42
661.63
676.05
674.769
674.769
674.269
665.8
636.556
636.556
636.556
635.91
635.91
635.91
635.91
635.91

DEMAND
gpm

PRESSURE

psi g

0 (source)

$-0.189$

2.668

$-11.1$

$-11.09$

$-6.676$

$-9.017$

$-11.48$

$-13.01$

$-12.27$

$-10.7$

$-10.32$

$-6.159$

8.232

8.284 (source)

8.284 (source)

8.546

8.565

8.597 (source)

8.565

8.597 (source)
H GRADE

$\mathrm{ft}$

608

608.1

615.3

616.2

616.2

625.7

631.8

637.9

649.2

649.4

652.7

653

653.1

653.6

653.7

653.7

653.6

653.6

653.7

653.6

653.7 


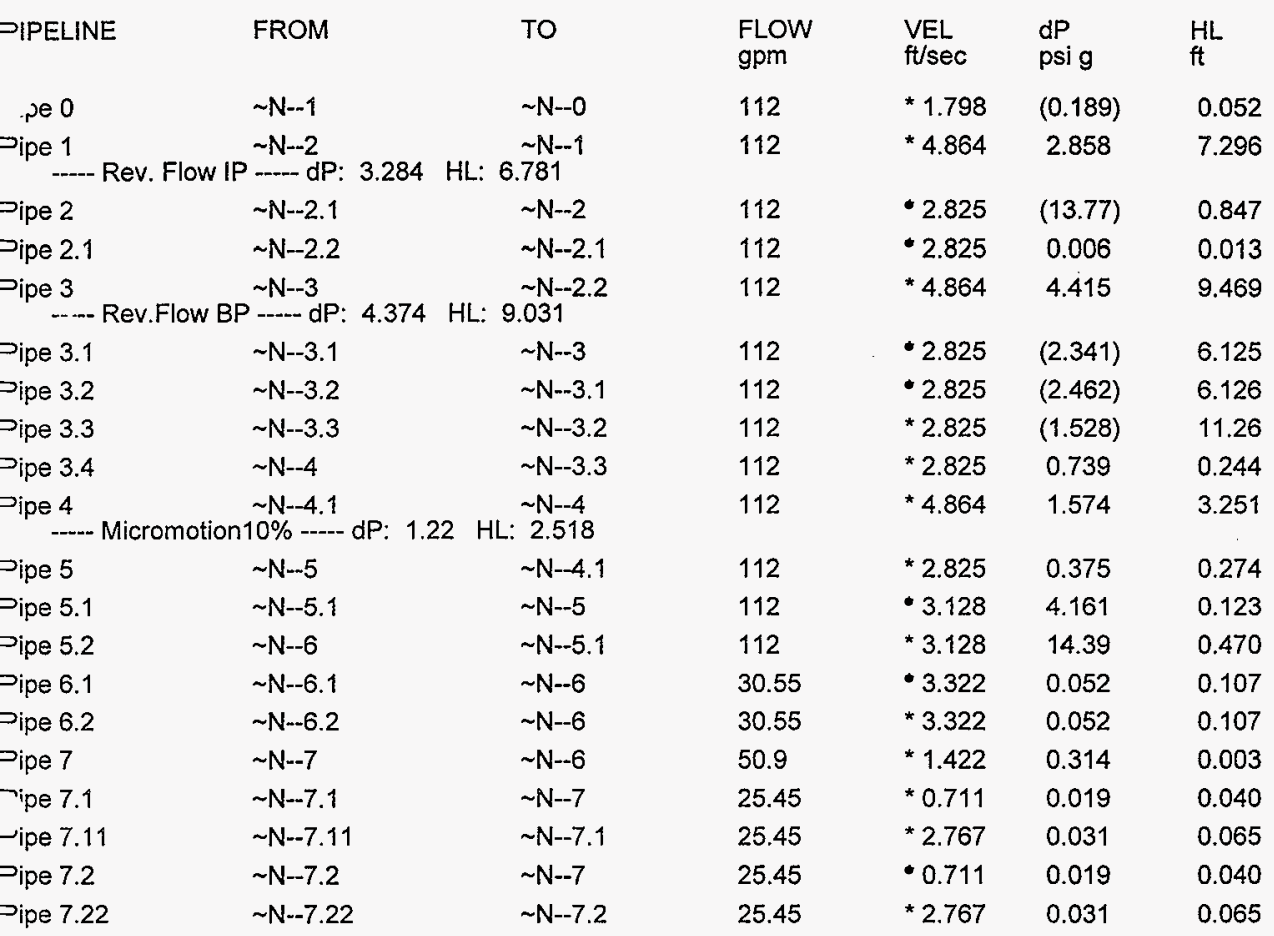


Company: Fluor Daniel Northwest

Project: W-320 Anti-Siphon Calculation by: D. L. Stone

Created: 01/24/97 1:41 pm Design file:

Pipe Specs: 2

\section{SYSTEM REPORT}

$03 / 13 / 97 \quad 3: 53 \mathrm{pm}$

System: SIPH10\%1

rev: 03/13/97 3:48 pm

Pipes: 20

Nodes: 21

Pumps/Comps: 3

$$
\text { Slurry Line - Siphoning - } 10 \% \text { Solids } \quad \text { (7OF) - configuration } 1
$$

SYSTEM NODES

NODE

$\sim \mathrm{N}-\mathrm{O}$

$\sim \mathrm{N}-1$

$\sim \mathrm{N}-2$

$\sim \mathrm{N}-2.1$

$\sim \mathrm{N}-2.2$

$\sim \mathrm{N}-\mathrm{3}$

$\sim \mathrm{N}-3.1$

$\sim \mathrm{N}-3.2$

$\sim N-3.3$

$\sim \mathrm{N}-4$

$\sim \mathrm{N}-4.1$

$\sim \mathrm{N}-5$

$\sim \mathrm{N}-5.1$

$\sim \mathrm{N}-6$

$\sim \mathrm{N}-6.1$

$\sim \mathrm{N}-6.2$

$\sim \mathrm{N}-7$

$\sim \mathrm{N}-7.1$

$-N-7.11$

$\sim \mathrm{N}-7.2$

$\sim \mathrm{N}-7.22$
ELEVATION

$\mathrm{ft}$

608

608.443

609.838

639.107

639.107

639.461

650.42

661.63

676.05

674.769

674.769

674.269

665.8

636.556

636.556

636.556

635.91

635.91

635.91

635.91

635.91
PIPELINES IN

PIPELINES OUT

Pipe 0

Pipe 1

Pipe 0

Pipe 2

Pipe 2.1

Pipe 1

Pipe 3

Pipe 3.1

Pipe 3.2

Pipe 2

Pipe 2.1

Pipe 3

Pipe 3.1

Pipe 3.3

Pipe 3.2

Pipe 3.4

Pipe 3.3

Pipe 4

Pipe 3.4

Pipe 5

Pipe 4

Pipe 5.1

Pipe 5

Pipe 5.2

Pipe 5.1

Pipe 6.1

Pipe 6.2

Pipe 7

Pipe 5.2

Pipe 6.1

Pipe 6.2

Pipe 7.1

Pipe 7.2

Pipe 7.11

Pipe 7.1

Pipe 7.11

Pipe 7.22

Pipe 7.2

Pipe 7.22 


\begin{tabular}{|c|c|c|c|c|}
\hline PIPELINE & SPEC & FROM_NODE & TO_NODE & PUMP/COMP \\
\hline Pipe 0 & 01 & $\sim N-1$ & $\sim N-0$ & \\
\hline Pipe 1 & 01 & $\sim N--2$ & $\sim N--1$ & Rev. Flow IP \\
\hline Pipe 2 & 01 & $\sim N-2.1$ & $\sim N-2$ & \\
\hline Pipe 2.1 & 01 & $\sim N--2.2$ & $\sim N--2.1$ & \\
\hline Pipe 3 & 01 & $\sim N--3$ & $\sim N--2.2$ & Rev.Flow BP \\
\hline Pipe 3.1 & 01 & $\sim N-3.1$ & $\sim N--3$ & \\
\hline Pipe 3.2 & 01 & $\sim N--3.2$ & $\sim N--3.1$ & \\
\hline Pipe 3.3 & 01 & $\sim N--3.3$ & $\sim N-3.2$ & \\
\hline Pipe 3.4 & 01 & $\sim N-4$ & $\sim N--3.3$ & \\
\hline Pipe 4 & 01 & $\sim N-4.1$ & $\sim N--4$ & Micromotion $10 \%$ \\
\hline Pipe 5 & 01 & $\sim N--5$ & $\sim N-4.1$ & \\
\hline Pipe 5.1 & 02 & $\sim N--5.1$ & $\sim \mathrm{N}--5$ & \\
\hline Fipe 5.2 & 02 & $\sim N--6$ & $\sim N--5.1$ & \\
\hline Pipe 6.1 & 02 & $\sim N--6.1$ & $\sim N--6$ & \\
\hline Pipe 6.2 & 02 & $\sim N--6.2$ & $\sim N--6$ & \\
\hline Pipe 7 & 02 & $\sim N--7$ & $\sim N--6$ & \\
\hline Pipe 7.1 & 02 & $\sim N--7.1$ & $\sim N--7$ & \\
\hline Pipe 7.11 & 02 & $\sim N--7.11$ & $\sim N--7.1$ & \\
\hline Pipe 7.2 & 02 & $\sim N--7.2$ & $\sim N--7$ & \\
\hline Pipe 7.22 & 02 & $\sim \mathrm{N}--7.22$ & $\sim N--7.2$ & \\
\hline
\end{tabular}




\section{PUMP/COMP}

Micromotion $10 \%$

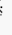

Rev. Flow IP

Rev.Flow BP

PERFORMANCE DATA

$\begin{array}{llllll}\text { gpm: } & 0 & 50 & 150 & 250 & 350 \\ \text { ft: } & 0 & 0.702 & 3.714 & 9.286 & 17.128 \\ \text { eqn: } & 0.00113187 Q^{\wedge} 1.63348 & & & \end{array}$

\begin{tabular}{llllll} 
gpm: & 0 & 40 & 80 & 120 & 150 \\
$\mathrm{ft}:$ & 0 & 0.86 & 3.45 & 7.78 & 12.2 \\
eqn: & \multicolumn{2}{l}{$0.000525277 \mathrm{Q}^{\wedge} 2.00609$} & &
\end{tabular}

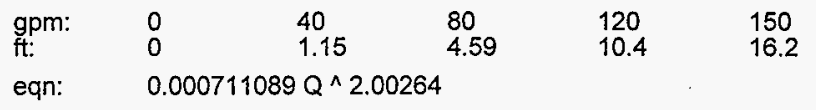

eqn: $\quad 0.000711089 Q^{\wedge} 2.00264$ 
Company: Fluor Daniel Northwest

Project:

by: D. L. Stone

Created: 01/24/97 1:41 pm

Design file:

Pipe Specs: 2
PIPELIST REPORT

Pipes: 20

Nodes: 21

Pumps/Comps: 3

$$
\text { Siurry Line - Siphoning - 10\% Solids (70F) - configuration } 1
$$

SPECIFICATIONS

\section{SPECIFICATION}

$0110 \% \operatorname{Sch} 40$ rev: 03/13/97 3:07 pm

$0210 \%$ Sch 80

rev: 03/17/97 7:16 am $\begin{array}{ll}\text { PIPE MATERIAL } & \text { FLUID } \\ \text { Sch / Roughness } & \text { Temp / Pres }\end{array}$

Steel

Sch 40

0.0018 in

Size for: $6 \mathrm{ft} / \mathrm{sec}$

Steel

Sch 80

0.0018 in

Size for: $6 \mathrm{ft} / \mathrm{sec}$
$10 \%$ solids

$70^{\circ} \mathrm{F}$

0 psig

$10 \%$ solids

$70^{\circ} \mathrm{F}$

0 psig
VALVE TABLE

Standard

Standard

$6-10 \mathrm{ft} / \mathrm{sec}$

$-14.4-300$ psi $g$
DESIGN LIMITS

Vel / Pres

$6-10 \mathrm{ft} / \mathrm{sec}$

$-14.4-300$ psi g 
PIPELINE

Pipe 0

Pipe 1

Pipe 2

Pipe 2.1

Pipe 3

Pipe 3.1

Pipe 3.2

Pipe 3.3

Pipe 3.4

Pipe 4

Pipe 5

Pipe 5.1

Pipe 5.2

Plpe 6.1

Pipe 6.2

Pipe 7

Pipe 7.1

Pipe 7.11

Pipe 7.2

Pipe 7.22
SPEC $\begin{aligned} & \text { MATERIAL } \\ & \text { Size/Sch }\end{aligned}$

01 Steel

5 in $/ 40$

01 Steel

3 in $/ 40$

01 Steel

4 in $/ 40$

01 Steel

4 in 140

01 Steel

3 in 140

01 Steel

4 in 140

01 Steel

4 in $/ 40$

01 Steel

4 in 140

01 Steel

4 in $/ 40$

01 Steel

3 in $/ 40$

01 Steel

4 in $/ 40$

02 Steel

$4 \mathrm{in} / 80$

02 Steel

4 in $/ 80$

02 Steel

2 in 180

02 Steel

2 in $/ 80$

02 Stee!

4 in $/ 80$

02 Steel

4 in $/ 80$

02 Steel

2 in $/ 80$

02 Steel

4 in 180

02 Steel

2 in $/ 80$
LENGTH
$\mathrm{ft}$

0.442

2.323

34.861

1

4.767

427.608

468.1

843.2

1.424

3.155

3.841

7.667

29.354

0.5

0.5

0.65

0.51

0.17

0.51

0.17
FLUID
Temp / Pres

$10 \%$ solids
$70{ }^{\circ} \mathrm{F} / 0$ psi g

$10 \%$ solids

$70^{\circ} \mathrm{F} / 0$ psi g

$10 \%$ solids

$70^{\circ} \mathrm{F} / 0$ psi g

$10 \%$ solids

$70^{\circ} \mathrm{F} / 0$ psi g

$10 \%$ solids

$70^{\circ} \mathrm{F} / 0$ psi g

$10 \%$ solids

$70^{\circ} \mathrm{F} / 0$ psi g

$10 \%$ solids

$70^{\circ} \mathrm{F} / 0$ psi g

$10 \%$ solids

$70^{\circ} \mathrm{F} / 0$ psi g

$10 \%$ solids

$70^{\circ} \mathrm{F} / 0$ psi g

$10 \%$ solids

$70^{\circ} \mathrm{F} / \mathrm{O}$ psi g

$10 \%$ solids

$70{ }^{\circ} \mathrm{F} / 0$ psi g

$10 \%$ solids

$70^{\circ} \mathrm{F} / 0$ psi g

$10 \%$ solids

$70^{\circ} \mathrm{F} / 0 \mathrm{psi} \mathrm{g}$

$10 \%$ solids

$70 \%$ F / 0 psi g

$10 \%$ solids

$70^{\circ} \mathrm{F} / 0$ psi g

$10 \%$ solids

$70^{\circ} \mathrm{F} / 0$ psi g

$10 \%$ solids

$70^{\circ} \mathrm{F} / 0$ psi g

$10 \%$ solids

$70{ }^{\circ} \mathrm{F} / 0$ psi g

$10 \%$ solids

$70{ }^{\circ} \mathrm{F} / 0$ psi g

$10 \%$ solids

$70^{\circ} \mathrm{F} / 0$ psi g
VALVES

1

1.112

3.303

0

0.5971

6.059

1.956

5.379

1.828

1.6

1.824

0

0

0.5

0.5

0

4.997

0.5

4.997

0.5 
Company: Fluor Daniel Northwest

Project: W-320 Anti-Siphon Calculation by: D. L. Stone

Created: 01/24/97 1:41 pm

Design file:

Pipe Specs: 2
MATERIALS REPORT

System: SIPH $10 \% 1$

rev: 03/13/97 3:48 pm
Pipes: 20

Nodes: 21

Pumps/Comps: 3

$$
\text { Slurry Line - Siphoning - 10\% Solids (70F) - configuration } 1
$$

PIPE MATERIALS LIST

PIPELINE

Pipe 0

Pipe 1

Pipe 2

Pipe 2.1

Pipe 3

Pipe 3.1

Pipe 3.2

Pipe 3.3

Pipe 3.4

Pipe 4

Pipe 5

Pipe 5.1
01 Steel

Steel
4 in $/ 40$

\section{SPEC MATERIAL Size / Sch}

01 Steel

5 in $/ 40$

01 Steel

3 in $/ 40$

$01 \quad$ Steel

4 in $/ 40$

Steel

4 in $/ 40$

01 Steel

3 in $/ 40$

4 in $/ 40$

01 Steel

4 in $/ 40$

01 Steel

4 in $/ 40$

01 Steel

3 in $/ 40$

01 Steel

4 in $/ 40$

4 in $/ 80$
$01 \quad$ Steel

02 Steel

\section{LENGTH VALVES \& FITTINGS} $\mathrm{ft}$

$0.442 \quad 1$-Exit Projecting

2.323

3-Elbow Short - r/d $1 @ 90^{\circ}$

1-Reducer Enlargement $4 \times 3$

34.861

1-Elbow Short-r/d $1 @ 45^{\circ}$

5-Elbow Short - r/d 1 @ 90

2-Elbow Long - r/d 1.5@90

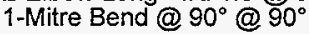

1

4.767 1-Reducer Contraction $4 \times 3$

1-Reducer Enlargement $4 \times 3$

2-Elbow Long - r/d $1.5 @ 90^{\circ}$

427.6082-Mitre Bend @ 90

3-Elbow Long - r/d $1.5 @ 90^{\circ}$

6-Pipe Bend $r / d 10 @ 90^{\circ}$

2-Pipe Bend r/d $8 @ 45^{\circ}$

468.14-Pipe Bend r/d $10 @ 90^{\circ}$

843.2 11-Pipe Bend r/d 10 @ 90

1.424 1-Mitre Bend @ 90

1-Elbow Long - r/d $1.5 @ 90^{\circ}$

1-Reducer Contraction $4 \times 3$

$3.155 \quad$ 1-Fixed K 1.357

1-Elbow Long - r/d 1.5 @ 90

3.8413 -Elbow Long - r/d 1.5 @ 90

1-Mitre Bend @ $90^{\circ}$

1-Reducer Enlargement $4 \times 3$ 


\begin{tabular}{|c|c|c|c|c|}
\hline PIPELINE & SPEC & $\begin{array}{l}\text { MATERIAL } \\
\text { Size / Sch }\end{array}$ & $\begin{array}{l}\text { LENGTH } \\
\mathrm{ft}\end{array}$ & VALVES \& FITTINGS \\
\hline Pipe 5.2 & 02 & $\begin{array}{l}\text { Steel } \\
4 \text { in } / 80\end{array}$ & 29.354 & \\
\hline Pipe 6.1 & 02 & $\begin{array}{l}\text { Steel } \\
2 \text { in / } 80\end{array}$ & 0.5 & 1-Entrance Sharp-Edged \\
\hline Pipe 6.2 & 02 & $\begin{array}{l}\text { Steel } \\
2 \text { in } / 80\end{array}$ & 0.5 & 1-Entrance Sharp-Edged \\
\hline Pipe 7 & 02 & $\begin{array}{l}\text { Steel } \\
4 \text { in / } 80\end{array}$ & 0.65 & \\
\hline Pipe 7.1 & 02 & $\begin{array}{l}\text { Steel } \\
4 \text { in } / 80\end{array}$ & 0.51 & 1-Reducer Enlargement $4 \times 2$ \\
\hline Pipe 7.11 & 02 & $\begin{array}{l}\text { Steel } \\
2 \text { in / } 80\end{array}$ & 0.17 & 1-Entrance Sharp-Edged \\
\hline Pipe 7.2 & 02 & $\begin{array}{l}\text { Steel } \\
4 \text { in / } 80\end{array}$ & 0.51 & 1-Reducer Enlargement $4 \times 2$ \\
\hline Pipe 7.22 & 02 & $\begin{array}{l}\text { Steel } \\
2 \text { in / } 80\end{array}$ & 0.17 & 1-Entrance Sharp-Edged \\
\hline
\end{tabular}


PIPE SUMMARY

PIPE MATERIAL

Steel

Steel

SPECIFICATION

$0.110 \% \operatorname{Sch} 40$

$0210 \%$ Sch 80
SCHEDULE SIZE

40

80

4 in

5 in

LENGTH

$10.245 \mathrm{ft}$ $1780.03 \mathrm{ft}$

$0.442 \mathrm{ft}$

$1.34 \mathrm{ft}$

4 in

$38.691 \mathrm{ft}$

VALVE \& FITTING SUMMARY

MATERIAL SCHEDULE VALVES \& FITTINGS

Steel

Size: 3 in

Size: 4 in

Size: 5 in

Steel

Size: 2 in

Size: 4 in
3-Elbow Short - r/d $1 @ 90^{\circ}$

2-Reducer Enlargement $4 \times 3$

1-Reducer Contraction $4 \times 3$

3-Elbow Long - r/d $1.5 @ 90^{\circ}$

1-Fixed K 1.357

1-Elbow Short-r/d $1 @ 45^{\circ}$

5-Elbow Short-r/d $1 @ 90^{\circ}$

9-Elbow Long - r/d $1.5 @ 90^{\circ}$

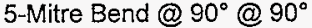

21-Pipe Bend r/d $10 @ 90^{\circ}$

2-Pipe Bend r/d $8 @ 45^{\circ}$

1-Reducer Contraction $4 \times 3$

1-Reducer Enlargement $4 \times 3$

1-Exit Projecting

80

4-Entrance Sharp-Edged

2-Reducer Enlargement $4 \times 2$ 
Company: Fluor Daniel Northwest

Project:

by: D. L. Stone

PIPING MATERIAL: Steel

Schedule: 40

abs roughness: 0.0018 in

PIPE SIZE: 4 in dia: 4.026 in

LENGTH: $3.841 \mathrm{ft}$

ELEVATION in: $674.269 \mathrm{ft}$ out: $674.769 \mathrm{ft}$
PIPELINE REPORT

Pipe 5 rev: 03/13/97 2:50 pm

SPECIFICATION: $10 \%$ Sch 40

SIZING Criteria: $6 \mathrm{ft} / \mathrm{sec}$

LIMITS Velocity: 6 to $10 \mathrm{ft} / \mathrm{sec}$

Pressure: -14.4 to 300 psi g

FLUID $10 \%$ solids at tmp: $70^{\circ} \mathrm{F}$

pres: 0 psi g

den: $69.78 \mathrm{lb} / \mathrm{ft}^{3}$

vsc: 12.87 cpois

$\begin{array}{llll}\begin{array}{l}\text { Flow } \\ \text { gpm }\end{array} & \text { ffp } & \begin{array}{l}\text { Vel } \\ \mathrm{ft} / \mathrm{sec}\end{array} & \begin{array}{l}\mathrm{dP} \\ \mathrm{psi}\end{array} \\ 112 & .0341 & 2.825 & 0.375 \\ 0 & .0000 & 0 & 0.242 \\ 33.04 & .0494 & 0.833 & 0.255 \\ 66.08 & .0396 & 1.667 & 0.290 \\ 99.12 & .0352 & 2.5 & 0.347 \\ 132.2 & .0326 & 3.333 & 0.426 \\ 165.2 & .0308 & 4.167 & 0.526 \\ 198.2 & .0294 & 5 & 0.648 \\ 231.3 & .0284 & 5.833 & 0.792 \\ 264.3 & .0275 & 6.667 & 0.956 \\ 297.4 & .0268 & 7.5 & 1.143 \\ 330.4 & .0262 & 8.333 & 1.35 \\ 363.4 & .0257 & 9.167 & 1.579 \\ 396.5 & .0252 & 10 & 1.829\end{array}$

VALVE / FITTING

Elbow Long - $r / d 1.590^{\circ}$

Reducer Enlargement $4 \times 3 \times 4$

VALVES and FITTINGS

K-VALUE VALVE/FITTING

K-VALUE

3@0.2282

0.1612

Mitre Bend @ $90^{\circ}$

0.978

FFT: 0.0163

TOTAL K: 1.824

Avg Percent of Total Loss: $84 \%$ 
Appendix F 


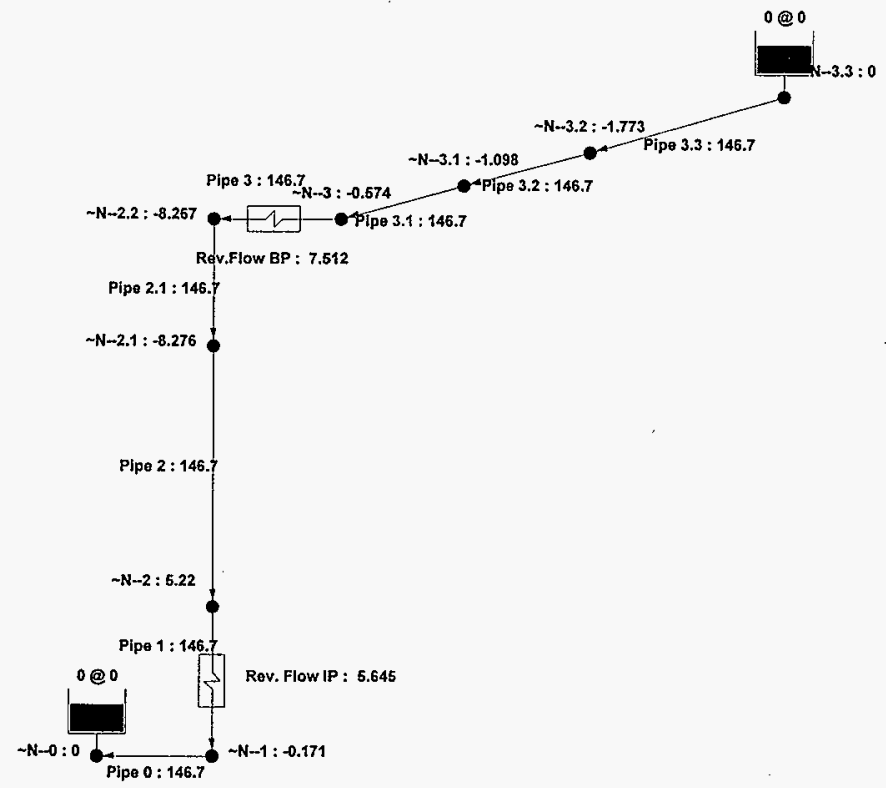

$\begin{aligned} \text { Company: } & \text { Fluor Daniel Northwest } \\ \text { Project: } & \text { W-320 Anti-Siphon and Drainflow } \\ \text { by: } & \text { D. L. Stone } \partial<5 \\ \text { Comments: } & \text { Slurry Line Drainflow - Highpoint to Endpoint - } 10 \% \\ & \text { Solids } \\ \text { Version: } & \text { PIPE-FLO ver } 5.01\end{aligned}$


System: DRAN10\%1

rev: 03/17/97 7:36 am

Deviation: $0.0011 \%$ after: 4 iterations

Slurry Line - Drain from High to Endpoint - 10\% Solids (7OF)

Volumetric flow rates require constant fluid properties in all pipelines. Fluid properties in the first specification were used in this calculation.

\section{LINEUP SUMMARIES}

PIPELINE

Pipe 0

Pipe 3.3

$\begin{aligned} & \begin{array}{l}\text { FLOW } \\ \text { gpm }\end{array} \\ \gg> & 146.7 \\ \ll \quad & 146.7\end{aligned}$

FLOW

46.7

《< 146.7
PRESSURE

SOURCE

$\sim \mathrm{N}-\mathrm{O}$

$\sim N-3.3$

\section{SET}

psig

0

0

Flows IN: $146.7 \mathrm{gpm}$

Flows OUT: $146.7 \mathrm{gpm}$

NET FLOWS: 0 gpm 
NODE

$\sim \mathrm{N}-\mathrm{O}$

ELEVATION DEMAND

$\mathrm{ft}$

gpm

PRESSURE

psig

H GRADE

608

0 (source)

608

$\sim \mathrm{N}-1$

608.443

$-0.171$

608.1

$\sim \mathrm{N}-\mathrm{-} 2$

609.838

5.22

620.6

$\sim \mathrm{N}-2.1$

639.107

$-8.276$

622

$\sim \mathrm{N}--2.2$

639.107

639.461

$-8.267$

622

$\sim \mathrm{N}-\mathrm{-3}$

650.42

$-0.574$

638.3

$\sim \mathrm{N}-3.1$

661.63

$-1.098$

648.2

$\sim \mathrm{N}-3.2$

676.05

$-1.773$

658

$\sim \mathrm{N}-\mathrm{-3} .3$

0 (source)

676 


\begin{tabular}{|c|c|c|c|c|c|c|}
\hline PIPELINE & FROM & TO & $\begin{array}{l}\text { FLOW } \\
\text { gpm }\end{array}$ & $\begin{array}{l}\text { VEL } \\
\mathrm{ft} / \mathrm{sec}\end{array}$ & $\begin{array}{l}\text { dP } \\
\text { psi g }\end{array}$ & $\begin{array}{l}\mathrm{HL} \\
\mathrm{ft}\end{array}$ \\
\hline je 0 & $\sim N--1$ & $\sim N--0$ & 146.7 & • 2.355 & $(0.171)$ & 0.089 \\
\hline $\begin{array}{l}\text { Pipe } 1 \\
\quad-- \text { Rev. Flow IP }\end{array}$ & $\sim N--2$ & HL: 11.66 & 146.7 & 6.372 & 5.392 & 12.53 \\
\hline Pipe 2 & $\sim N-2.1$ & $\sim N--2$ & 146.7 & * 3.701 & (13.5) & 1.402 \\
\hline Pipe 2.1 & $\sim \mathrm{N}-2.2$ & $\sim \mathrm{N}-2.1$ & 146.7 & - 3.701 & 0.010 & 0.020 \\
\hline $\begin{array}{l}\text { Pipe } 3 \\
\\
\end{array}$ & $\sim \mathrm{N}-3$ & $\mathrm{HL}: \frac{\sim \mathrm{N}--2.2}{15.51}$ & 146.7 & 6.372 & 7.693 & 16.24 \\
\hline Pipe 3.1 & $\sim N-3.1$ & $\sim N--3$ & 146.7 & * 3.701 & $(0.524)$ & 9.876 \\
\hline Pipe 3.2 & $\sim \mathrm{N}-3.2$ & $\sim N--3.1$ & 146.7 & * 3.701 & $(0.674)$ & 9.818 \\
\hline Pipe 3.3 & $\sim \mathrm{N}-3.3$ & $\sim \mathrm{N}-3.2$ & 146.7 & * 3.701 & 1.773 & 18.08 \\
\hline
\end{tabular}




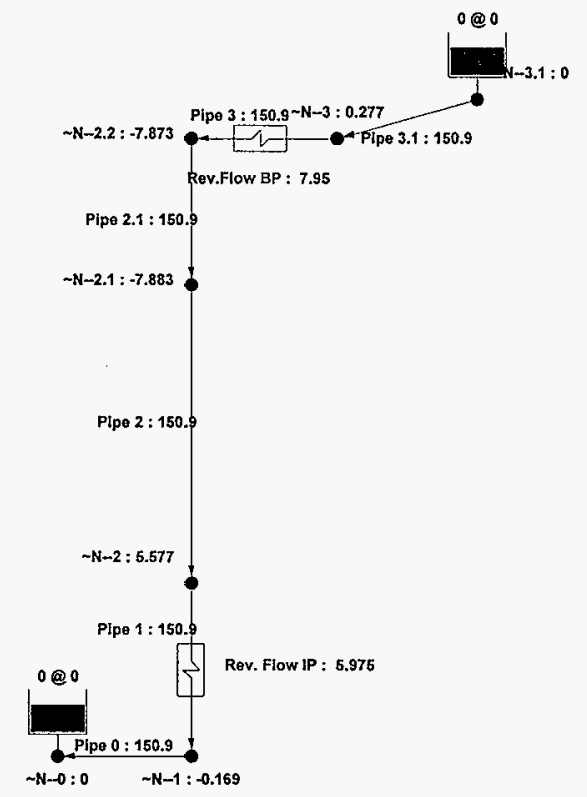
Company: Fluor Daniel Northwest
Project: W-320 Anti-Siphon and Drainflow
by: D. L. Stone DLS
Comments: Slurry Line Drainflow - Lowpoint to Endpoint - 10\% Solids
Version: PIPE-FLO ver 5.01

$03 / 17 / 97 \quad 1: 03 \mathrm{pm}$

Linelist: DRAN10\%2

Lineup: DRAN10\%2

flow rate: $\mathrm{gpm}$

pressure: $p s i g$

level \& grade: $\mathrm{ft}$ 
System: DRAN10\%2

rev: 03/17/97 12:43 pm

Deviation: $0.000921 \%$

after: 5 iterations

Slurry Line - Drain from Stationpoint to Endpoint - 10\% Solids (70F)

Volumetric flow rates require constant fluid properties in all pipelines. Fluid properties in the first specification were used in this calculation.

\section{LINEUP SUMMARIES}

PIPELINE

Pipe 0

Pipe 3.1
FLOW

gpm

$\gg \quad 150.9$

$\ll 150.9$
PRESSURE

SOURCE

$\sim N-0$

$\sim \mathrm{N}-\mathrm{3} .1$
SET
psig

0

0
LEVEL

ft

0

0

Flows IN: $150.9 \mathrm{gpm}$

Flows OUT: $150.9 \mathrm{gpm}$

NET FLOWS: $0 \mathrm{gpm}$ 
NODE

\begin{tabular}{|c|c|c|}
\hline $\begin{array}{l}\text { ELEVATION } \\
\mathrm{ft}\end{array}$ & $\begin{array}{l}\text { DEMAND } \\
\text { gpm }\end{array}$ & $\begin{array}{l}\text { PRESSURE } \\
\text { psi } g\end{array}$ \\
\hline
\end{tabular}

A System Component is out of range - results may not be valid.

$\sim N-0$

608

0 (source)

608

$\sim \mathrm{N}-1$

608.443

$-0.169$

608.1

$\sim \mathrm{N}-\mathrm{-2}$

609.838

5.577

621.4

$\sim \mathrm{N}-2.1$

639.107

$-7.883$

622.8

$\sim \mathrm{N}-2.2$

639.107

$-7.873$

622.9

$\sim \mathrm{N}-\mathrm{-3}$

639.461

0.277

640

$\sim \mathrm{N}-\mathrm{-3.1}$

650.42

0 (source)

650.4 


\begin{tabular}{|c|c|c|c|}
\hline PIPELINE & FROM & TO & $\begin{array}{l}\text { FLOW } \\
\text { gpm }\end{array}$ \\
\hline
\end{tabular}

A System Component is out of range - results may not be valid.

\begin{tabular}{|c|c|c|c|c|c|c|}
\hline Pipe 0 & $\sim N--1$ & $\sim N--0$ & 150.9 & $* 2.422$ & $(0.169)$ & 0.094 \\
\hline Pipe 1 & $\stackrel{\sim N--2}{\text { (out of range)----- dP: }}$ & $\begin{array}{c}\sim N-1 \\
5.975\end{array}$ HL: 12.34 & 150.9 & 6.555 & 5.746 & 13.26 \\
\hline Pipe 2 & $-N-2.9$ & $\sim N-2$ & 150.9 & $\cdot 3.807$ & $(13.46)$ & 1.478 \\
\hline Pipe 2.1 & $\sim \mathrm{N}-2.2$ & $\sim N--2.1$ & 150.9 & * 3.807 & 0.010 & 0.021 \\
\hline Pipe 3 & $\stackrel{\sim N--3}{\text { (out of range) }-\cdots-\cdots} d P$ & 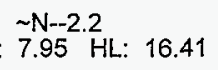 & 150.9 & 6.555 & 8.15 & 17.1 \\
\hline Pipe 3.1 & $\sim N-3.1$ & $\sim N--3$ & 150.9 & * 3.807 & $(0.277)$ & 0. \\
\hline
\end{tabular}


Appendix G

HNF-2477, Rev. 0

Page B-84 


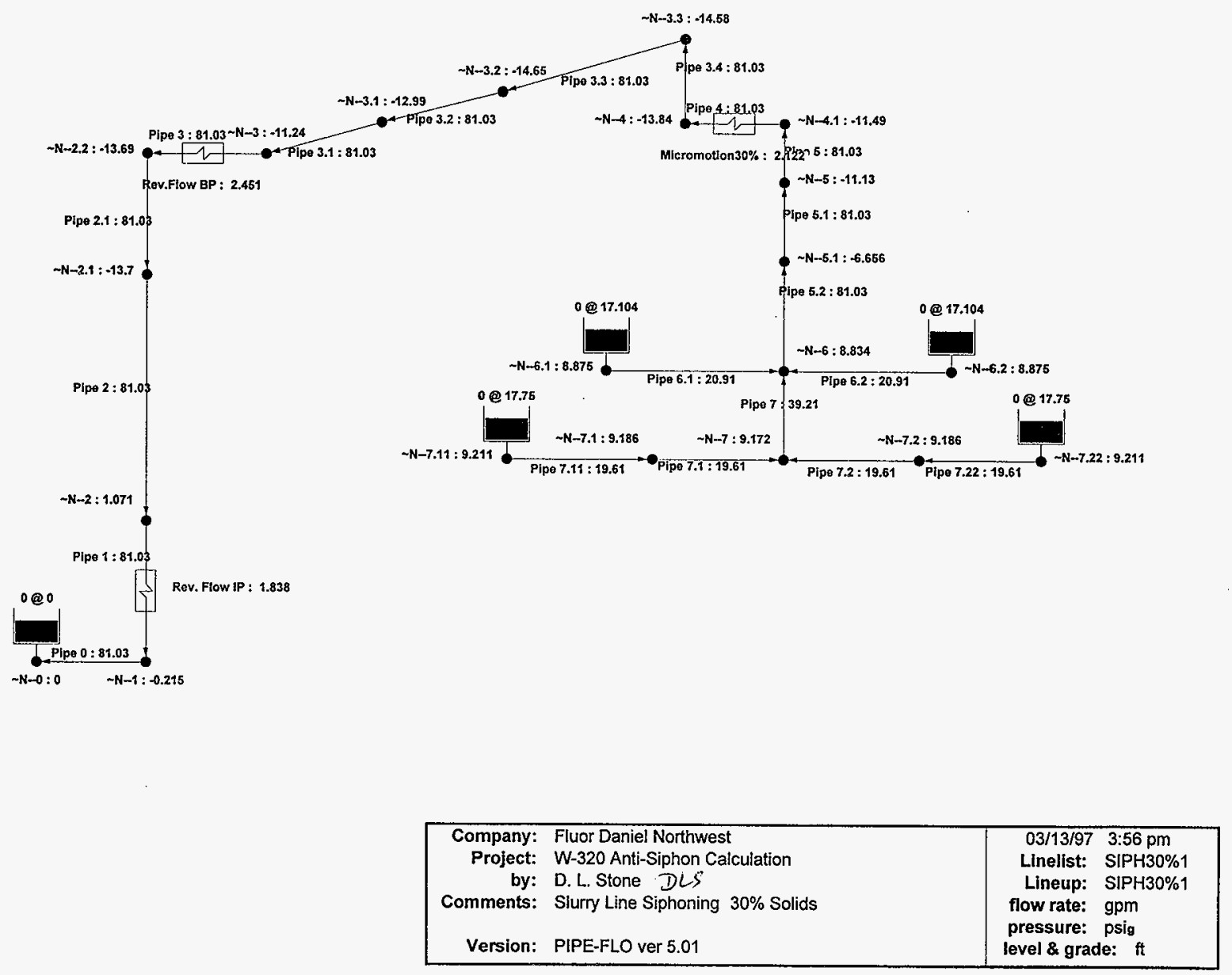


System: SIPH30\%1

rev: 03/13/97 $3: 47 \mathrm{pm}$

Deviation: $0.0044 \%$ after: 12 iterations

Slurry Line - Siphon - 30\% Solids (70F) -configuration 1

Volumetric flow rates require constant fluid properties in all pipelines. Fluid properties in the first specification were used in this calculation.

\section{LINEUP SUMMARIES}

PIPELINE

Pipe 0

Pipe 6.1

Pipe 6.2

Pipe 7.11

Pipe 7.22
FLOW gpm

> 81.03

« 20.91

« 20.91

$\ll 19.61$

$\ll 19.61$
PRESSURE

SOURCE

$\sim \mathrm{N}-\mathrm{O}$

$\sim N--6.1$

$\sim N--6.2$

$\sim \mathrm{N}-7.11$

$\sim N-7.22$

SET
psig

$0 \quad 0$

0

17.1

17.1

17.75

17.75

Flows IN: $81.04 \mathrm{gpm}$ Flows OUT: $81.03 \mathrm{gpm}$ NET FLOWS IN: $0.010 \mathrm{gpm}$ 
NODE

$\sim \mathrm{N}-\mathrm{O}$

$\sim \mathrm{N}-1$

$\sim \mathrm{N}-\mathrm{-2}$

$\begin{array}{ll}\text { ELEVATION } & \text { DEMAND } \\ \mathrm{ft} & \mathrm{gpm}\end{array}$

PRESSURE

psig

H GRADE

608

0 (source)

$\mathrm{ft}$

608.443

$-0.215$

608

609.838

1.071

608

$\sim \mathrm{N}-2.1$

639.107

$-13.7$

611.9

$\sim \mathrm{N}-2.2$

639.107

$-13.69$

612.7

$\sim \mathrm{N}-\mathrm{3}$

639.461

$\sim N-3.1$

650.42

$\sim \mathrm{N}-3.2$

661.63

676.05

674.769

$-11.24$

612.7

617.8

$-12.99$

625.4

$-14.65^{* * *}$

633.4

-14.58 *ะ*

648

$-13.84$

648.1

674.769

$-11.49$

652.6

674.269

665.8

$-11.13$

652.8

$\sim N--5.1$

636.556

$-6.656$

653

$\sim N--6$

636.556

8.834

653.6

$\sim \mathrm{N}-6.1$

636.556

8.875 (source)

653.7

8.875 (source)

653.7

635.91

9.172

653.6

635.91

9.186

653.6

635.91

9.211 (source)

653.7

635.91

9.186

653.6

635.91

9.211 (source)

653.7 


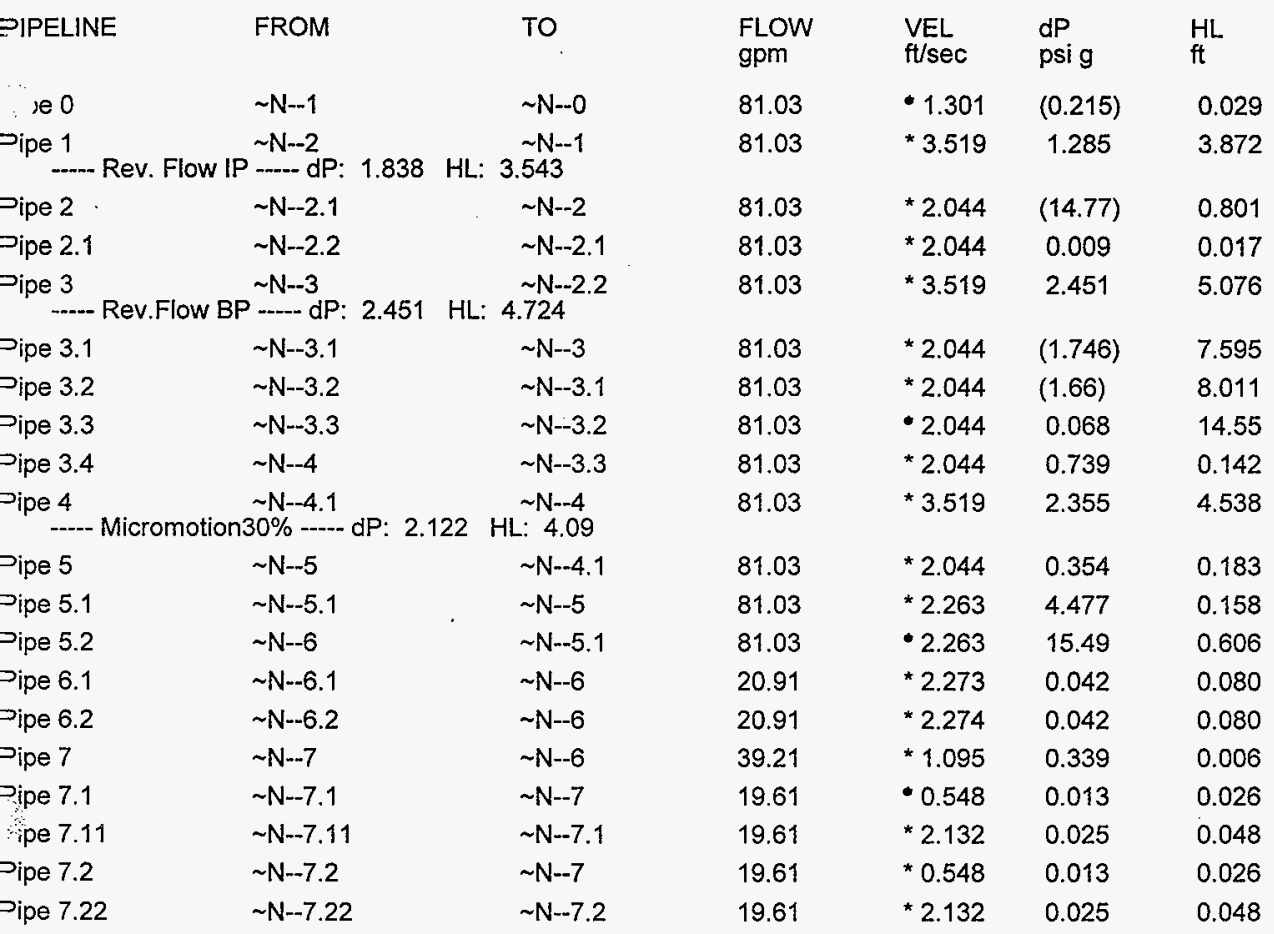


Company: Fluor Daniel Northwest

Project: W-320 Anti-Siphon Calculation by: D. L. Stone

Created: 01/24/97 1:41 pm

SYSTEM REPORT

Design file:

Pipe Specs: 2
03/13/97 4:07 pm

System: SIPH $30 \% 1$

rev: 03/13/97 3:47 pm

Pipes: 20

Nodes: 21

Pumps/Comps: 3

$$
\text { Slurry Line - Siphoning - } 30 \% \text { Solids (7OF) - configuration } 1
$$

SYSTEM NODES

\begin{tabular}{|c|c|c|c|}
\hline NODE & $\begin{array}{l}\text { ELEVATION } \\
\mathrm{ft}\end{array}$ & PIPELINES IN & PIPELINES OUT \\
\hline$\sim N--0$ & 608 & Pipe 0 & \\
\hline$\sim \mathrm{N}-1$ & 608.443 & Pipe 1 & Pipe 0 \\
\hline$\sim N--2$ & 609.838 & Pipe 2 & Pipe 1 \\
\hline$\sim N--2.1$ & 639.107 & Pipe 2.1 & Pipe 2 \\
\hline$\sim N--2.2$ & 639.107 & Pipe 3 & Pipe 2.1 \\
\hline$\sim N--3$ & 639.461 & Pipe 3.1 & Pipe 3 \\
\hline$\sim N--3.1$ & 650.42 & Pipe 3.2 & Pipe 3.1 \\
\hline$\sim N--3.2$ & 661.63 & Pipe 3.3 & Pipe 3.2 \\
\hline$\sim N-3.3$ & 676.05 & Pipe 3.4 & Pipe 3.3 \\
\hline$\sim N--4$ & 674.769 & Pipe 4 & Pipe 3.4 \\
\hline$\sim N-4.1$ & 674.769 & Pipe 5 & Pipe 4 \\
\hline$\sim N-5$ & 674.269 & Pipe 5.1 & Pipe 5 \\
\hline$\sim N--5.1$ & 665.8 & Pipe 5.2 & Pipe 5.1 \\
\hline$\sim N--6$ & 636.556 & $\begin{array}{l}\text { Pipe 6.1 } \\
\text { Pipe 6.2 } \\
\text { Pipe } 7\end{array}$ & Pipe 5.2 \\
\hline$\sim N-6.1$ & 636.556 & & Pipe 6.1 \\
\hline$\sim N--6.2$ & 636.556 & & Pipe 6.2 \\
\hline$\sim N--7$ & 635.91 & $\begin{array}{l}\text { Pipe } 7.1 \\
\text { Pipe } 7.2\end{array}$ & Pipe 7 \\
\hline$\sim N--7.1$ & 635.91 & Pipe 7.11 & Pipe 7.1 \\
\hline$\sim N--7.11$ & 635.91 & & Pipe 7.11 \\
\hline$\sim N--7.2$ & 635.91 & Pipe 7.22 & Pipe 7.2 \\
\hline$\sim N--7.22$ & 635.91 & & Pipe 7.22 \\
\hline
\end{tabular}


PIPELINE

Pipe 0

Pipe 1

Pipe 2

Pipe 2.1

Pipe 3

Pipe 3.1

Pipe 3.2

Pipe 3.3

Pipe 3.4

Pipe 4

Pipe 5

Pipe 5.1

Pipe 5.2

Pipe 6.1

Pipe 6.2

Pipe 7

Pipe 7.1

Pipe 7.11

Pipe 7.2

Pipe 7.22
SPEC

03

03

03

03

03

03

03

03

03

03

03

04

04

04

04

04

04

04

04

04
FROM_NODE

$\sim \mathrm{N}-1$

$\sim \mathrm{N}-2$

$\sim \mathrm{N}-2.1$

$\sim \mathrm{N}-2.2$

$\sim \mathrm{N}-3$

$\sim N-3.1$

$\sim \mathrm{N}-3.2$

$\sim \mathrm{N}-3.3$

$\sim \mathrm{N}-4$

$\sim N-4.1$

$\sim \mathrm{N}-5$

$\sim N-5.1$

$\sim N-6$

$\sim N-6.1$

$\sim \mathrm{N}-6.2$

$\sim \mathrm{N}-7$

$\sim \mathrm{N}-7.1$

$\sim \mathrm{N}-7.11$

$\sim \mathrm{N}-7.2$

$\sim \mathrm{N}-7.22$
TO_NODE

$\sim \mathrm{N}-\mathrm{O}$

$\sim N-1$

$\sim N-2$

$\sim \mathrm{N}-\mathrm{-2.1}$

$\sim \mathrm{N}-2.2$

$\sim \mathrm{N}-\mathrm{-3}$

$\sim \mathrm{N}-\mathrm{-3.1}$

$\sim N-3.2$

$\sim \mathrm{N}-\mathrm{-3.3}$

$\sim \mathrm{N}-4$

$\sim N-4.1$

$\sim \mathrm{N}-5$

$\sim N-5.1$

$\sim N-6$

$\sim N-6$

$\sim N--6$

$\sim \mathrm{N}-7$

$\sim N-7.1$

$\sim \mathrm{N}-7$

$\sim N-7.2$

PUMP/COMP

Rev. Flow IP

Rev.Flow BP

Micromotion $30 \%$ 


\begin{tabular}{lllllll} 
PUMP/COMP & \multicolumn{7}{l}{ PERFORMANCE DATA } \\
Micromotion30\% & gpm: & 0 & 50 & 150 & 250 & 350 \\
& ft: & 0 & 2.311 & 7.704 & 19.26 & 33.705 \\
& eqn: & 0.0100732 & $Q^{\wedge} 1.36669$ & & & \\
Rev. Flow IP & gpm: & 0 & 40 & 80 & 120 & 150 \\
& ft: & 0 & 0.86 & 3.45 & 7.78 & 12.2 \\
& eqn: & $0.000525277 Q^{\wedge} 2.00609$ & & \\
Rev.Flow BP & gpm: & 0 & 40 & 80 & 120 & 150 \\
& ft: & 0 & 1.15 & 4.59 & 10.4 & 16.2 \\
& eqn: & \multicolumn{7}{l}{$0.000711089 Q^{\wedge} 2.00264$} & &
\end{tabular}


Company: Fluor Daniel Northwest

Project: W-320 Anti-Siphon Calculation by: D. L. Stone

Created: $01 / 24 / 97$ 1:41 pm Design file:

Pipe Specs: 2
PIPELIST REPORT

Pipes: 20

Nodes: 21

Pumps/Comps: 3

Slurry Line - Siphoning - $30 \%$ Solids (7OF) - configuration 1

SPECIFICATIONS

\section{SPECIFICATION}

$0330 \%$ Sch 40

rev: 03/13/97 $3: 34 \mathrm{pm}$

$0430 \% \operatorname{Sch} 80$

rev: 03/13/97 $3: 35 \mathrm{pm}$ $\begin{array}{ll}\text { PIPE MATERIAL } & \text { FLUID } \\ \text { Sch / Roughness } & \text { Temp/Pres }\end{array}$

Steel

$\operatorname{Sch} 40$

0.0018 in

Size for: $6 \mathrm{ft} / \mathrm{sec}$

Steel

Sch 80

0.0018 in

Size for: $6 \mathrm{ft} / \mathrm{sec}$
$30 \%$ solids

$70^{\circ} \mathrm{F}$

Opsig
VALVE TABLE DESIGN LIMITS Vel / Pres

Standard

$6-10 \mathrm{ftsec}$

$-14.4-300$ psig
Standard

$6-10 \mathrm{ft} / \mathrm{sec}$

$-14.4-300$ psi g 
PIPELINE

Pipe 0

Pipe 1

Pipe 2

Pipe 2.1

Pipe 3

Pipe 3.1

Pipe 3.2

Pipe 3.3

Pipe 3.4

Pipe 4

Pipe 5

Pipe 5.1

Pipe 5.2

Pipe 6.1

Pipe 6.2

Pipe 7

Pipe 7.1

Pipe 7.11

Pipe 7.2

Pipe 7.22

\section{SPEC MATERIAL Size / Sch}

03 Steel

5 in $/ 40$

03 Steel

3 in $/ 40$

03 Steel

4 in $/ 40$

03 Steel

4 in $/ 40$

03 Steel

3 in $/ 40$

03 Steel

4 in $/ 40$

03 Steel

$4 \mathrm{in} / 40$

03 Steel

4 in $/ 40$

03 Steel

4 in $/ 40$

03 Steel

3 in $/ 40$

03 Steel

4 in $/ 40$

04 Steel

4 in 180

04 Steel

4 in 180

04 Steel

2 in 180

04 Steel

2 in 180

04 Steel

4 in 180

04 Steel

4 in 180

04 Steel

2 in 180

04 Steel

4 in / 80

04 Steel

2 in 180
LENGTH

0.442

2.323

34.861

1

4.767

427.608

468.1

843.2

1.424

3.155

3.841

7.667

29.354

0.5

0.5

0.65

0.51

0.17

0.51

0.17
FLUID
Temp / Pres

$30 \%$ solids

$70{ }^{\circ} \mathrm{F} / 0$ psi g

$30 \%$ solids

$70^{\circ} \mathrm{F} / 0$ psi g

$30 \%$ solids

$70^{\circ} \mathrm{F} / 0$ psi g

$30 \%$ solids

$70{ }^{\circ} \mathrm{F} / 0$ psig

$30 \%$ solids

$70{ }^{\circ} \mathrm{F} / 0$ psi g

$30 \%$ solids

$70{ }^{\circ} \mathrm{F} / 0$ psi g

$30 \%$ solids

$70{ }^{\circ} \mathrm{F} / 0$ psi g

$30 \%$ solids

$70^{\circ} \mathrm{F} / 0$ psi g

$30 \%$ solids

$70{ }^{\circ} \mathrm{F} / 0$ psig

$30 \%$ solids

$70^{\circ} \mathrm{F} / 0$ psi g

$30 \%$ solids

$70{ }^{\circ} \mathrm{F} / 0$ psig

$30 \%$ solids

$70{ }^{\circ} \mathrm{F} / 0$ psi g

$30 \%$ solids

$70{ }^{\circ} \mathrm{F} / 0$ psi g

$30 \%$ solids

$70{ }^{\circ} \mathrm{F} / 0$ psi g

$30 \%$ solids

$70{ }^{\circ} \mathrm{F} / 0$ psig

$30 \%$ solids

$70{ }^{\circ} \mathrm{F} / 0$ psi g

$30 \%$ solids

$70{ }^{\circ} \mathrm{F} / 0$ psig

$30 \%$ solids

$70^{\circ} \mathrm{F} / 0$ psi g

$30 \%$ solids

$70{ }^{\circ} \mathrm{F} / 0$ psig

$30 \%$ solids

$70^{\circ} \mathrm{F} / 0$ psig
VALVES

1

1.112

3.303

0

0.5971

6.059

1.956

5.379

1.828

1.51

1.824

0

0

0.5

0.5

0

4.997

0.5

4.997

0.5 
Company: Fluor Daniel Northwest

Project: W-320 Anti-Siphon Calculation by: D. L. Stone

Created: $01 / 24 / 97 \quad 1: 41 \mathrm{pm}$

Design file:

Pipe Specs: 2
MATERIALS REPORT
03/13/97 4:07 pm

System: SIPH $30 \% 1$

rev: 03/13/97 3:47 pm

Pipes: 20

Nodes: 21

Pumps/Comps: 3

$$
\text { Slurry Line - Siphoning - 30\% Solids (7OF) - configuration } 1
$$

PIPE MATERIALS LIST

PIPELINE

Pipe 0

Pipe 1

Pipe 2

Pipe 2.1

Pipe 3

Pipe 3.1

Pipe 3.2

Pipe 3.3

Pipe 3.4

03 Steel

4 in $/ 40$

03 Steel

4 in $/ 40$

03 Steel

4 in $/ 40$

03 Steel

4 in $/ 40$

Pipe 4

03 Steel

3 in 140

Pipe 5

03 Steel

4 in $/ 40$

04 Steel

4 in $/ 80$

Pipe 5.1

\section{LENGTH VALVES \& FITTINGS}

$\mathrm{ft}$

$0.442 \quad 1$-Exit Projecting

2.323

3-Elbow Short-r/d $1 @ 90^{\circ}$

1-Reducer Enlargement $4 \times 3$

34.861 1-Elbow Short - r/d $1 @ 45^{\circ}$

5-Elbow Short - r/d $1 @ 90^{\circ}$

2-Elbow Long - r/d 1.5@90

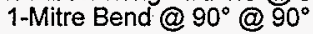

1

$4.767 \quad$ 1-Reducer Contraction $4 \times 3$

1-Reducer Enlargement $4 \times 3$

2-Elbow Long - r/d 1.5 @ 90

427.608 2-Mitre Bend @ $90^{\circ}$

3-Elbow Long-r/d $1.5 @ 90^{\circ}$

6-Pipe Bend $r / d 10 @ 90^{\circ}$

2-Pipe Bend r/d $8 @ 45^{\circ}$

468.14-Pipe Bend $r / d 10 @ 90^{\circ}$

843.2 11-Pipe Bend $r / d 10 @ 90^{\circ}$

1.424 1-Mitre Bend @ 90

1-Elbow Long - r/d 1.5@90

1-Reducer Contraction $4 \times 3$

3.155 1-Elbow Long-r/d $1.5 @ 90^{\circ}$ 1-Fixed K 1.267

$3.8413-E l b o w$ Long - r/d $1.5 @ 90^{\circ}$ 1-Mitre Bend @ $90^{\circ}$

1-Reducer Enlargement $4 \times 3$

7.667 


\begin{tabular}{|c|c|c|c|c|}
\hline PIPELINE & SPEC & $\begin{array}{l}\text { MATERIAL } \\
\text { Size / Sch }\end{array}$ & $\begin{array}{l}\text { LENGTH } \\
\mathrm{ft}\end{array}$ & VALVES \& FITTINGS \\
\hline Pipe 5.2 & 04 & $\begin{array}{l}\text { Steel } \\
4 \text { in } / 80\end{array}$ & 29.354 & \\
\hline Pipe 6.1 & 04 & $\begin{array}{l}\text { Steel } \\
2 \text { in / } 80\end{array}$ & 0.5 & 1-Entrance Sharp-Edged \\
\hline Pipe 6.2 & 04 & $\begin{array}{l}\text { Steel } \\
2 \text { in / } 80\end{array}$ & 0.5 & 1-Entrance Sharp-Edged \\
\hline Pipe 7 & 04 & $\begin{array}{l}\text { Steel } \\
4 \text { in / } 80\end{array}$ & 0.65 & \\
\hline Pipe 7.1 & 04 & $\begin{array}{l}\text { Steel } \\
4 \text { in } / 80\end{array}$ & 0.51 & 1-Reducer Enlargement $4 \times 2$ \\
\hline Pipe 7.11 & 04 & $\begin{array}{l}\text { Steel } \\
2 \text { in / } 80\end{array}$ & 0.17 & 1-Entrance Sharp-Edged \\
\hline Pipe 7.2 & 04 & $\begin{array}{l}\text { Steel } \\
4 \text { in / } 80\end{array}$ & 0.51 & 1-Reducer Enlargement $4 \times 2$ \\
\hline Pipe 7.22 & 04 & $\begin{array}{l}\text { Steel } \\
2 \text { in / } 80\end{array}$ & 0.17 & 1-Entrance Sharp-Edged \\
\hline
\end{tabular}


PIPE SUMMARY

PIPE MATERIAL

Steel

Steel

\section{SPECIFICATION}

SCHEDULE

40

80
40
SIZE

3 in

4 in

5 in

2 in

4 in
$03 / 13 / 97 \quad 4: 07 \mathrm{pm}$

\section{LENGTH}

$10.245 \mathrm{ft}$

$1780.03 \mathrm{ft}$

$0.442 \mathrm{ft}$

$1.34 \mathrm{ft}$

$38.691 \mathrm{ft}$

VALVE \& FITTING SUMMARY

$0330 \% \operatorname{Sch} 40$

MATERIAL

Steel

Size: 3 in

Size: 4 in

Size: 5 in

$0430 \%$ Sch 80
Steel

Size: 2 in

Size: 4 in

\section{SCHEDULE VALVES \& FITTINGS}

3-Elbow Short - r/d 1 @ 90

2-Reducer Enlargement $4 \times 3$

1-Reducer Contraction $4 \times 3$

3-Elbow Long - r/d $1.5 @ 90^{\circ}$

1-Fixed K 1.267

1-Elbow Short - r/d $1 @ 45^{\circ}$

5-Elbow Short - r/d $1 @ 90^{\circ}$

9-Elbow Long - r/d $1.5 @ 90^{\circ}$

5-Mitre Bend @ 90 @ 90

21-Pipe Bend $r / d 10 @ 90^{\circ}$

2-Pipe Bend r/d $8 @ 45^{\circ}$

1-Reducer Contraction $4 \times 3$

1-Reducer Enlargement $4 \times 3$

1-Exit Projecting

80

4-Entrance Sharp-Edged

2-Reducer Enlargement $4 \times 2$ 
Company: Fluor Daniel Northwest

Project:

by: D. L. Stone

PIPING MATERIAL: Steel Schedule: 40

abs roughness: 0.0018 in

PIPE SIZE: 4 in

dia: 4.026 in

LENGTH: $3.841 \mathrm{ft}$

ELEVATION in: $674.269 \mathrm{ft}$ out: $674.769 \mathrm{ft}$
PIPELINE REPORT

Pipe 5 rev: 03/13/97 3:39 pm

SPECIFICATION: $30 \% \operatorname{Sch} 40$

SIZING Criteria: $6 \mathrm{ft} / \mathrm{sec}$

LIMITS Velocity: 6 to $10 \mathrm{ft} / \mathrm{sec}$

Pressure: -14.4 to 300 psi g

FLUUID $30 \%$ solids at tmp: $70^{\circ} \mathrm{F}$ pres: 0 psi g den: $74.77 \mathrm{lb} / \mathrm{ft}^{3}$ vsc: 103.9 cpois

PIPELINE RESISTANCE CURVE

$\begin{array}{llll}\begin{array}{l}\text { Flow } \\ \text { gpm }\end{array} & \text { ffp } & \begin{array}{l}\text { Vel } \\ \mathrm{ft} / \mathrm{sec}\end{array} & \begin{array}{l}\mathrm{dP} \\ \mathrm{psi}\end{array} \\ 81.03 & .0872 & 2.044 & 0.354 \\ 0 & .0000 & 0 & 0.260 \\ 33.04 & .2139 & 0.833 & 0.283 \\ 66.08 & .1069 & 1.667 & 0.328 \\ 99.12 & .0713 & 2.5 & 0.392 \\ 132.2 & .0535 & 3.333 & 0.477 \\ 165.2 & .0428 & 4.167 & 0.583 \\ 198.2 & .0356 & 5 & 0.709 \\ 231.3 & .0306 & 5.833 & 0.855 \\ 264.3 & .0484 & 6.667 & 1.11 \\ 297.4 & .0465 & 7.5 & 1.327 \\ 330.4 & .0450 & 8.333 & 1.567 \\ 363.4 & .0436 & 9.167 & 1.831 \\ 396.5 & .0424 & 10 & 2.119\end{array}$

VALVE / FITTING

Elbow Long - $r / d 1.590^{\circ}$

Reducer Enlargement $4 \times 3 \times 4$

VALVES and FITTINGS

K-VALUE VALVE/FITTING

K-VALUE

3@0.2282

0.1612

0.978

FFT: 0.0163

TOTAL K: 1.824

Avg Percent of Total Loss: $73 \%$ 
Appendix $\mathrm{H}$

HNF-2477, Rev. 0

Page B-98 

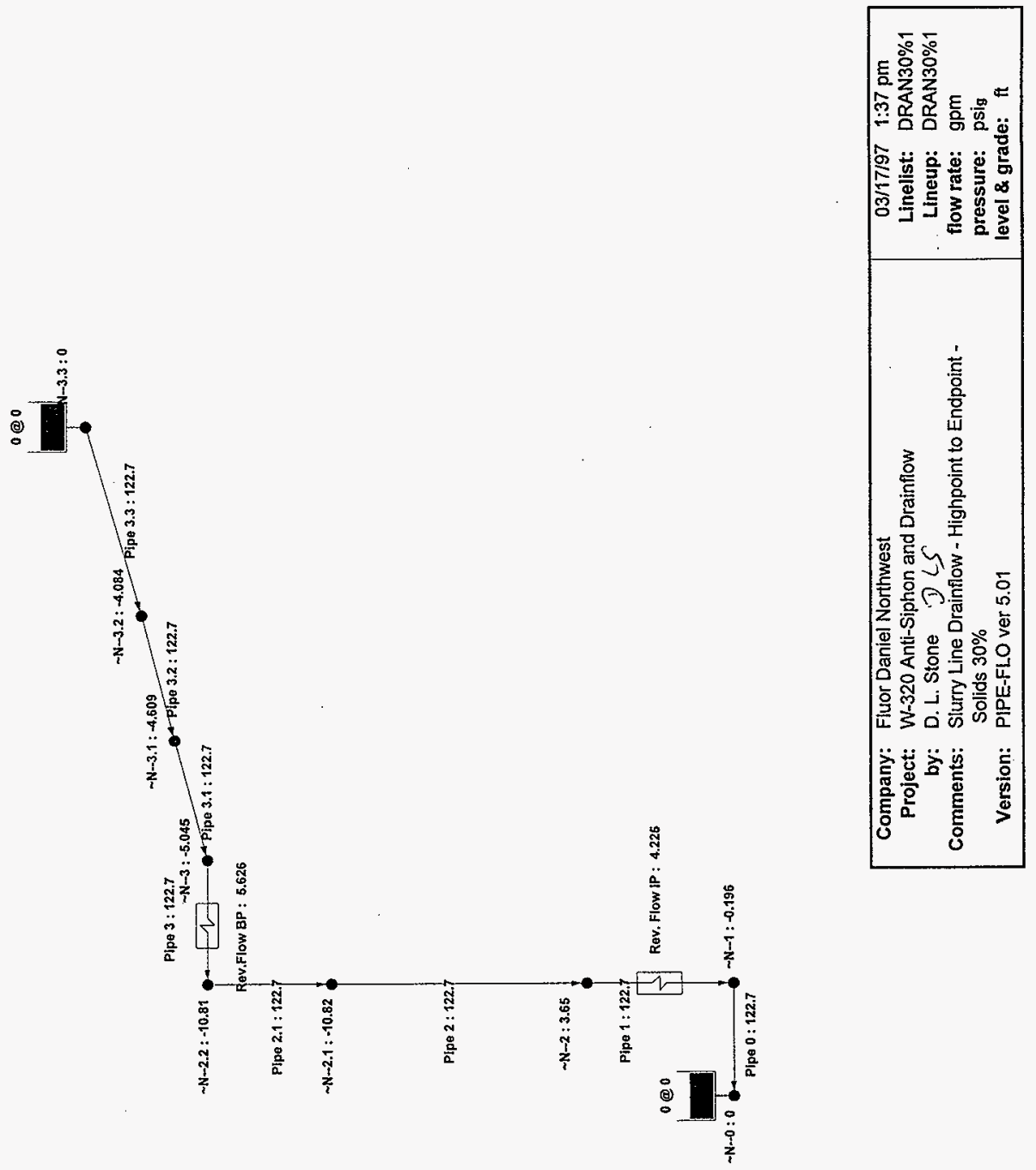
System: DRAN30\% 1 rev: $03 / 17 / 971: 34 \mathrm{pm}$
Deviation: $0.00418 \%$ after: 8 iterations

Slurry Line - Drain from High to Endpoint - 30\% Solids (7OF)

Volumetric flow rates require constant fluid properties in all pipelines. Fluid properties in the first specification were used in this calculation.

\section{LINEUP SUMMARIES}

PIPELINE

Pipe 0

Pipe 3.3
FLOW

$\mathrm{gpm}$

>> 122.7

« 122.7
PRESSURE SOURCE

$\sim \mathrm{N}-\mathrm{O}$

$\sim \mathrm{N}-\mathrm{-3.3}$

\section{SET}

psig

0

0

LEVEL

Flows IN: $122.7 \mathrm{gpm}$

Flows OUT: $122.7 \mathrm{gpm}$

NET FLOWS: $0 \mathrm{gpm}$ 
NODE

$\sim N-0$

$\sim \mathrm{N}-1$

$\sim \mathrm{N}-2$

$\sim \mathrm{N}-2.1$

$\sim N-2.2$

$-N-3$

$\sim N-3.1$

$\sim N-3.2$

$\sim N-3.3$
ELEVATION DEMAND

$\mathrm{ft}$

608

608.443

609.838

639.107

639.107

639.461

650.42

661.63

676.05

gpm
PRESSURE

psig

0 (source)

$-0.196$

3.65

$-10.82$

$-10.81$

$-5.045$

$-4.609$

$-4.084$

0 (source)
H GRADE

$\mathrm{ft}$

608

608.1

616.9

618.3

618.3

629.7

641.5

653.8

676 


\begin{tabular}{|c|c|c|c|c|c|c|}
\hline PIPELINE & FROM & TO & $\begin{array}{l}\text { FLOW } \\
\text { gpm }\end{array}$ & $\begin{array}{l}\text { VEL } \\
\mathrm{ft} / \mathrm{sec}\end{array}$ & $\begin{array}{l}\mathrm{dP} \\
\text { psi g }\end{array}$ & $\begin{array}{l}\mathrm{HL} \\
\mathrm{ft}\end{array}$ \\
\hline je 0 & $\sim N-1$ & $\sim N-0$ & 122.7 & * 1.969 & $(0.196)$ & 0.065 \\
\hline Pipe 1 & $\begin{array}{l}\sim \mathrm{N}--2 \\
---\mathrm{dP}: 4.225\end{array}$ & HL: 8.142 & 122.7 & - 5.329 & 3.846 & 8.807 \\
\hline Pipe 2 & $\sim N--2.1$ & $\sim N--2$ & 122.7 & * 3.095 & (14.47) & 1.379 \\
\hline Pipe 2.1 & $\sim N--2.2$ & $\sim N--2.1$ & 122.7 & * 3.095 & 0.013 & 0.025 \\
\hline Pipe 3 & $\sim N--3$ & HL: 10.84 & 122.7 & * 5.329 & 5.765 & 11.46 \\
\hline Pipe 3.1 & $\sim N--3.1$ & $\sim N--3$ & 122.7 & * 3.095 & 0.436 & 11.8 \\
\hline Pipe 3.2 & $\sim \mathrm{N}-3.2$ & $\sim N-3.1$ & 122.7 & * 3.095 & 0.525 & 12.22 \\
\hline Pipe 3.3 & $\sim N--3.3$ & $\sim N-3.2$ & 122.7 & * 3.095 & 4.084 & 22.29 \\
\hline
\end{tabular}



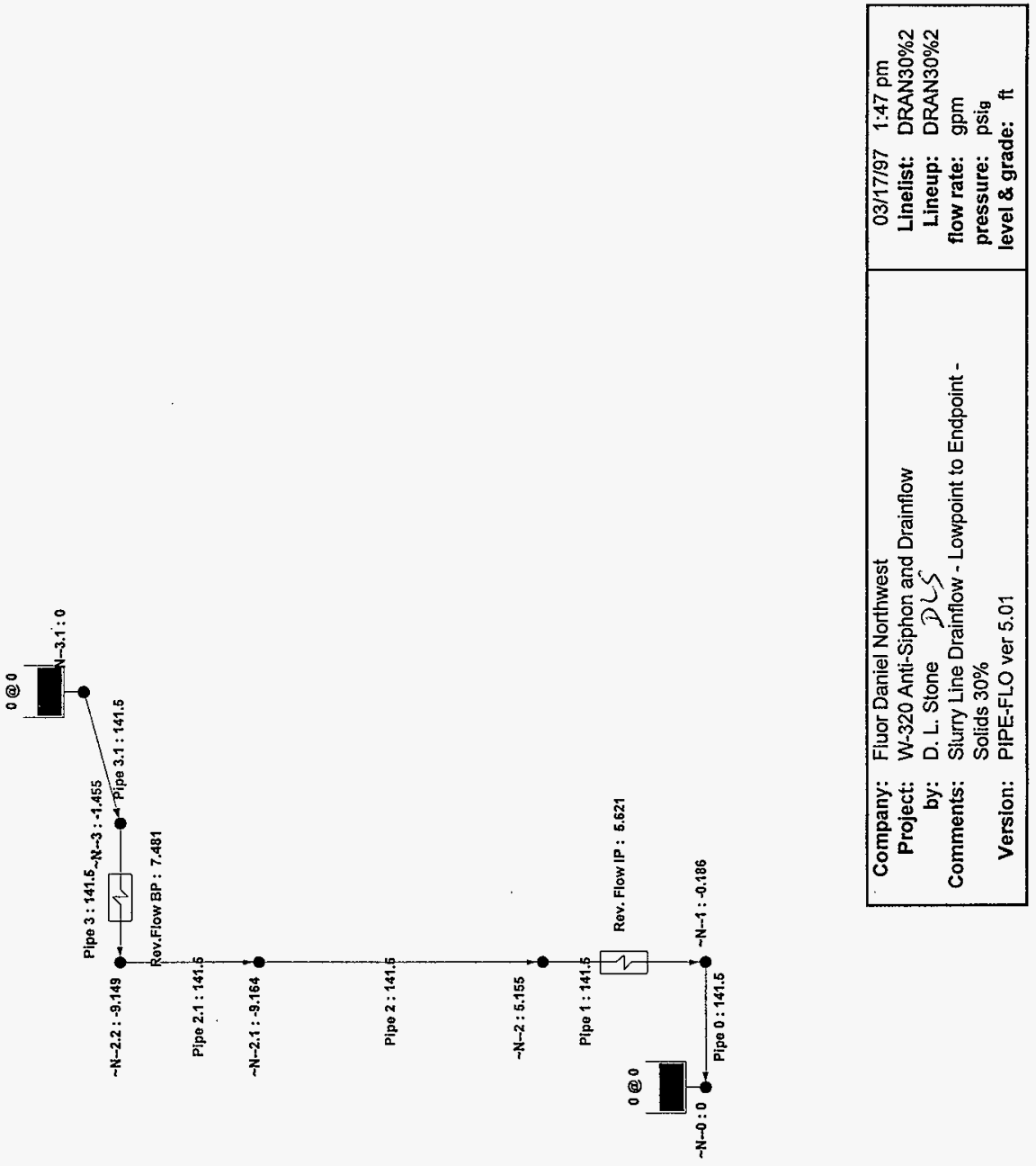

HNF-2477, Rev. 0 
Company: Fluor Daniel Northwest

Project: W-320 Anti-Siphon and Drainflow by: D. L. Stone

System: DRAN30\%2

rev: 03/17/97 $1: 43 \mathrm{pm}$

Deviation: $0.00184 \%$ after: 7 iterations

Slurry Line - Drain from Stationpoint to Endpoint - 30\% Solids (7OF)

Volumetric flow rates require constant fluid properties in all pipelines. Fluid properties in the first specification were used in this calculation.

LINEUP SUMMARIES

PIPELINE

Pipe 0

Pipe 3.1
FLOW

gpm

>> 141.5

$\ll \quad 141.5$
PRESSURE

SOURCE

$\sim \mathrm{N}-\mathrm{O}$

$\sim N-3.1$

$\begin{array}{ll}\text { SET } & \text { LEVEL } \\ \text { psig } & \mathrm{ft}\end{array}$

0

0

0

Flows IN: $141.5 \mathrm{gpm}$

Flows OUT: $141.5 \mathrm{gpm}$

NET FLOWS: $0 \mathrm{gpm}$ 
NODE

$\sim N-0$

$\sim \mathrm{N}-1$

$\sim \mathrm{N}-\mathrm{-2}$

$\sim \mathrm{N}-2.1$

$\sim \mathrm{N}-2.2$

$\sim N-3$

$\sim N--3.1$
ELEVATION DEMAND

$\mathrm{ft} \quad \mathrm{gpm}$

608

608.443

609.838

639.107

639.107

639.461

650.42
PRESSURE

psig

0 (source)

$-0.186$

5.155

$-9.164$

$-9.149$

$-1.455$

0 (source)
H GRADE it

608

608.1

619.8

621.4

621.5

636.7

650.4 


\begin{tabular}{|c|c|c|c|c|c|c|}
\hline PIPELINE & FROM & TO & $\begin{array}{l}\text { FLOW } \\
\text { gpm }\end{array}$ & $\begin{array}{l}\text { VEL } \\
\mathrm{ft} / \mathrm{sec}\end{array}$ & $\begin{array}{l}\text { dP } \\
\text { psig }\end{array}$ & $\begin{array}{l}\mathrm{HL} \\
\mathrm{ft}\end{array}$ \\
\hline )e 0 & $\sim N--1$ & $\sim N--0$ & 141.5 & * 2.27 & $(0.186)$ & 0.085 \\
\hline Pipe 1 Rev. Flow IP & $\sim \mathrm{N}--2$ & $\mathrm{HL}: \tilde{\sim 0.83}^{\mathrm{N}-1}$ & 141.5 & 6.144 & 5.34 & 11.69 \\
\hline Pipe 2 & $\sim N--2.1$ & $\sim N--2$ & 141.5 & * 3.568 & (\$4.32) & 1.677 \\
\hline Pipe 2.1 & $\sim \mathrm{N}--2.2$ & $\sim N-2.1$ & 141.5 & * 3.568 & 0.015 & 0.029 \\
\hline Pipe 3 Rev.Flow BP & $\stackrel{\sim N-3}{\sim}$ dP: 7.481 & $\mathrm{HL}: \tilde{14.42}^{\sim \mathrm{N}-2.2}$ & 141.5 & 6.144 & 7.694 & 15.18 \\
\hline Pipe 3.1 & $\sim N--3.1$ & $\sim N--3$ & 141.5 & * 3.568 & 1.455 & 13.76 \\
\hline
\end{tabular}




\section{Appendix I}


$-N-4:-11.95$

PIpe $3: 75: 41$ Pos Flow 2: 1.187

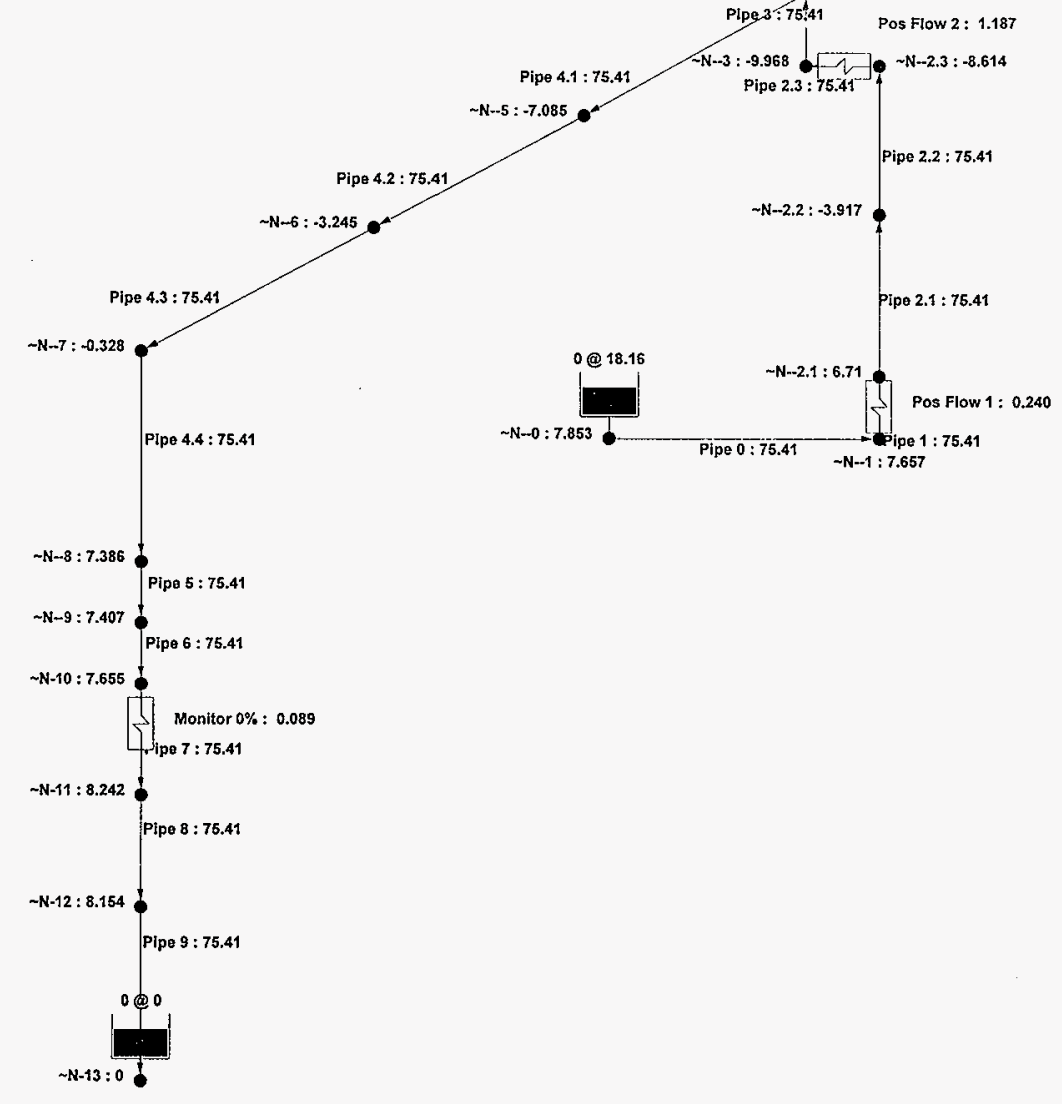

Company: Fluor Daniel Northwest

Project: W-320 Anti-Siphon and Drainflow

by: D. L. Stone $D L S$

Comments: Supernate Line Siphoning - Solids $0 \%$

Version: PIPE-FLO ver 5.01
03/17/97 3:06 pm

Linelist: SIPH $0 \% 1$

Lineup: SIPH $0 \% 1$

flow rate: $\mathrm{gpm}$

pressure: psig level \& grade: ft 
System: SIPHO\%1

rev: 03/17/97 2:34 pm

Deviation: $0.00207 \%$ after: 6 iterations

Supernate Line - $0 \%$ solids - Siphon Function

Volumetric flow rates require constant fluid properties in all pipelines. Fluid properties in the first specification were used in this calculation.

\section{LINEUP SUMMARIES}

PIPELINE

Pipe 0

Pipe 9
FLOW gpm

$\ll 75.41$

$\gg 75.41$
PRESSURE SOURCE

$\sim \mathrm{N}-\mathrm{O}$

$\sim \mathrm{N}-13$
SET

psig

0

0
LEVEL

18.16

0

Flows IN: $75.41 \mathrm{gpm}$

Flows OUT: $75.41 \mathrm{gpm}$

NET FLOWS: $0 \mathrm{gpm}$ 
NODE

$\sim \mathrm{N}-\mathrm{O}$

$\sim \mathrm{N}-1$

$\sim \mathrm{N}-\mathrm{-2.1}$

$\sim \mathrm{N}-\mathrm{-2.2}$

$\sim \mathrm{N}-\mathrm{-2.3}$

$\sim \mathrm{N}-\mathrm{-3}$

$\sim \mathrm{N}-\mathrm{-}$

$\sim N--5$

$\sim \mathrm{N}-6$

$\sim \mathrm{N}-7$

$\sim \mathrm{N}-\mathrm{-8}$

$\sim \mathrm{N}-\mathrm{9}$

$\sim \mathrm{N}-10$

$\sim \mathrm{N}-11$

$\sim \mathrm{N}-12$

$\sim \mathrm{N}-13$

$\begin{array}{ll}\text { ELEVATION } & \text { DEMAND } \\ \mathrm{ft} & \mathrm{gpm}\end{array}$

635.5

635.943

637.338

661.7

672.315

672.669

677.11

661.63

650.39

641.42

623.217

622.517

621.85

620.225

619.621

619.35
PRESSURE

psig

7.853 (source) $\quad 653.7$

7.657

6.71

$-3.917$

$-8.614$

$-9.968$

$-11.95$

$-7.085$

$-3.245$

$-0.328$

7.386

7.407

7.655

8.242

8.154

0 (source)

640.7
H GRADE

$\mathrm{ft}$

653.6

652.9

652.6

652.4

649.6

649.5

645.2

642.9

640.3

639.6

639.6

639.3

638.5

619.3 


\begin{tabular}{|c|c|c|c|c|c|c|}
\hline PIPELINE & FROM & TO & $\begin{array}{l}\text { FLOW } \\
\text { gpm }\end{array}$ & $\begin{array}{l}\text { VEL } \\
\mathrm{ft} / \mathrm{sec}\end{array}$ & $\begin{array}{l}d P \\
\text { psig }\end{array}$ & $\begin{array}{l}\mathrm{HL} \\
\mathrm{ft}\end{array}$ \\
\hline je 0 & $\sim N--0$ & $\sim N--1$ & 75.41 & $* 1.21$ & 0.197 & 0.012 \\
\hline Pipe 1 & $\begin{array}{l}\sim \mathrm{N}-\mathrm{-1} \\
\cdots \mathrm{dP}: \quad 0.240\end{array}$ & HL: $0.554^{\sim N--2.1}$ & 75.41 & * 3.275 & 0.947 & 0.794 \\
\hline Pipe 2.1 & $\sim N--2.1$ & $\sim \mathrm{N}-2.2$ & 75.41 & $\star 1.902$ & 10.63 & 0.212 \\
\hline Pipe 2.2 & $\sim \mathrm{N}--2.2$ & $\sim N--2.3$ & 75.41 & $* 1.902$ & 4.697 & 0.245 \\
\hline Pipe 2.3 & $\begin{array}{l}\sim N--2.3 \\
--d P: 1.187\end{array}$ & $H L: 2^{\sim N-}{ }^{N-3}$ & 75.41 & $* 3.275$ & 1.354 & 2.776 \\
\hline Pipe 3 & $-N--3$ & $\sim N--4$ & 75.41 & * 1.902 & 1.983 & 0.144 \\
\hline Pipe 4.1 & $\sim N--4$ & $\sim N--5$ & 75.41 & * 1.902 & $(4.865)$ & 4.23 \\
\hline Pipe 4.2 & $\sim N--5$ & $\sim N--6$ & 75.41 & * 1.902 & $(3.84)$ & 2.36 \\
\hline Pipe 4.3 & $\sim N--6$ & $\sim N-7$ & 75.41 & * 1.902 & $(2.917)$ & 2.225 \\
\hline Pipe 4.4 & $\sim N--7$ & $\sim N--8$ & 75.41 & * 1.902 & $(7.714)$ & 0.365 \\
\hline Pipe 5 & $\sim N--8$ & $\sim N--9$ & 75.41 & $* 5.057$ & $(0.021)$ & 0.652 \\
\hline Pipe 6 & $\sim N--9$ & $\sim N-10$ & 75.41 & 7.216 & $(0.249)$ & 0.092 \\
\hline Pipe 7 & $\begin{array}{l}\sim N-10 \\
\sim d P: 0.089\end{array}$ & $H L: 0.207^{-N-11}$ & 75.41 & * 5.057 & $(0.587)$ & 0.268 \\
\hline Pipe 8 & $\sim \mathrm{N}-11$ & $\sim N-12$ & 75.41 & * 5.057 & 0.089 & 0.809 \\
\hline Pipe 9 & $\sim N-12$ & $\sim N-13$ & 75.41 & $\star 33.66$ & 8.154 & 19.13 \\
\hline
\end{tabular}


Company: Fluor Daniel Northwest

Project: W-320 Anti-Siphon and Drainflow by: D. L. Stone

Created: 01/24/97 1:41 pm

Design file:

Pipe Specs: 2

\section{SYSTEM REPORT}

03/17/97 3:06 pm

System: SIPHO\%1

rev: 03/17/97 2:34 pm

Pipes: 15

Nodes: 16

Pumps/Comps: 3

Supernate Line - 0\% Solids - Siphon Function (7OF)

SYSTEM NODES

NODE

$\sim \mathrm{N}-\mathrm{O}$

$\sim N--1$

$\sim \mathrm{N}-2.1$

$\sim N--2.2$

$\sim \mathrm{N}-\mathrm{-2.3}$

$\sim \mathrm{N}-\mathrm{-3}$

$\sim \mathrm{N}-\mathrm{-4}$

$\sim \mathrm{N}-\mathrm{-5}$

$\sim N-6$

$\sim \mathrm{N}-\mathrm{-7}$

$\sim \mathrm{N}-\mathrm{-8}$

$\sim \mathrm{N}-\mathrm{-9}$

$\sim \mathrm{N}-10$

$\sim N-11$

$\sim \mathrm{N}-12$

$\sim N-13$
ELEVATION

ft

635.5

635.943

637.338

661.7

672.315

672.669

677.11

661.63

650.39

641.42

623.217

622.517

621.85

620.225

619.621

619.35
PIPELINES IN

PIPELINES OUT

Pipe 0

Pipe 0

Pipe 1

Pipe 1

Pipe 2.1

Pipe 2.1

Pipe 2.2

Pipe 2.2

Pipe 2.3

Pipe 2.3

Pipe 3

Pipe 3

Pipe 4.1

Pipe 4.1

Pipe 4.2

Pipe 4.2

Pipe 4.3

Pipe 4.3

Pipe 4.4

Pipe 4.4

Pipe 5

Pipe 5

Pipe 6

Pipe 6

Pipe 7

Pipe 7

Pipe 8

Pipe 8

Pipe 9

Pipe 9 
PIPELINE

\section{Pipe 0}

Pipe 1

Pipe 2.1

Pipe 2.2

Pipe 2.3

Pipe 3

Pipe 4.1

Pipe 4.2

Pipe 4.3

Pipe 4.4

Pipe 5

Pipe 6

Pipe 7

Pipe 8

Pipe 9

$\begin{array}{ll}\text { SPEC } & \text { FROM_NODE } \\ 03 & \sim N--0 \\ 03 & \sim N--1 \\ 03 & \sim N--2.1 \\ 03 & \sim N--2.2 \\ 03 & \sim N--2.3 \\ 03 & \sim N--3 \\ 03 & \sim N--4 \\ 03 & \sim N--5 \\ 03 & \sim N--6 \\ 03 & \sim N--7 \\ 03 & \sim N--8 \\ 03 & \sim N--9 \\ 03 & \sim N-10 \\ 03 & \sim N-11 \\ 04 & \sim N-12\end{array}$

TO_NODE

$\sim \mathrm{N}-1$

$\sim \mathrm{N}-2.1$

$\sim \mathrm{N}-\mathrm{-2} .2$

$\sim \mathrm{N}-2.3$

$\sim \mathrm{N}-\mathrm{3}$

$\sim N-4$

$\sim \mathrm{N}-\mathrm{-5}$

$\sim \mathrm{N}-6$

$\sim N-.7$

$\sim N-8$

$\sim \mathrm{N}-\mathrm{9}$

$\sim N-10$

$-N-11$

$\sim N-12$

$\sim N-13$
PUMP/COMP

Pos Flow 1

Pos Flow 2

Monitor 0\% 
PUMP/COMP

Monitor $0 \%$

Pos Flow 1

Pos Flow 2

\section{PERFORMANCE DATA}

$\begin{array}{llllll}\text { gpm: } & 0 & 50 & 150 & 250 & 350 \\ \mathrm{ft:} & 0 & 0.098 & 0.717 & 1.87 & 3.55\end{array}$

eqn: $\quad 7.20527 e-005 Q \wedge 1.84168$

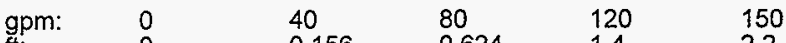

$\begin{array}{llllll}\mathrm{ft}: & 0 & 0.156 & 0.624 & 1.4 & 2.2\end{array}$

eqn: $\quad 9.72278 \mathrm{e}-005 Q^{\wedge} 2.00063$

$\begin{array}{llllll}\text { gpm: } & 0 & 40 & 80 & 120 & 150 \\ \mathrm{ft}: & 0 & 0.77 & 3.08 & 7 & 10.9\end{array}$

eqn: $\quad 0.000468926 Q^{\wedge} 2.00674$ 
Company: Fluor Daniel Northwest

Project: W-320 Anti-Siphon and Drainflow by: D. L. Stone

Created: 01/24/97 1:41 pm

Design file:

Pipe Specs: 2

\section{PIPELIST REPORT}

03/17/97 3:07 pm

System: SIPHO\% 1

rev: 03/17/97 2:34 pm

Pipes: 15

Nodes: 16

Pumps/Comps: 3

Supernate Line - 0\% Solids - Siphon Function (70F)

SPECIFICATIONS

\begin{tabular}{|c|c|c|c|c|}
\hline SPECIFICATION & $\begin{array}{l}\text { PIPE MATERIAL } \\
\text { Sch / Roughness }\end{array}$ & $\begin{array}{l}\text { FLUID } \\
\text { Temp / Pres }\end{array}$ & VALVE TABLE & $\begin{array}{l}\text { DESIGN LIMITS } \\
\text { Vel / Pres }\end{array}$ \\
\hline \multirow[t]{2}{*}{$\begin{array}{l}\text { C3 } 0 \%-70 F-s c h 40 \\
\text { rev: 01/31/97 } 12: 53 \mathrm{pm}\end{array}$} & $\begin{array}{l}\text { Steel } \\
\text { Sch } 40 \\
0.0018 \text { in }\end{array}$ & $\begin{array}{l}0 \% \text { solids } \\
70^{\circ} \mathrm{F} \\
0 \text { psi g }\end{array}$ & Standard & $\begin{array}{l}6-10 \mathrm{ft} / \mathrm{sec} \\
-14.4-300 \text { psi g }\end{array}$ \\
\hline & Size for: $6 \mathrm{ft} / \mathrm{sec}$ & & & \\
\hline $\begin{array}{l}040 \%-70 F-s c h 80 \\
\text { rev: } 01 / 31 / 9712: 53 \mathrm{pm}\end{array}$ & $\begin{array}{l}\text { Steel } \\
\text { Sch } 80 \\
0.0018 \text { in }\end{array}$ & $\begin{array}{l}0 \% \text { solids } \\
70^{\circ} \mathrm{F} \\
0 \text { psig }\end{array}$ & Standard & $\begin{array}{l}6-10 \mathrm{ft} / \mathrm{sec} \\
-14.4-300 \text { psi g }\end{array}$ \\
\hline
\end{tabular}

Size for: $6 \mathrm{ft} / \mathrm{sec}$ 


\begin{tabular}{|c|c|c|c|c|c|}
\hline PIPELINE & SPEC & $\begin{array}{l}\text { MATERIAL } \\
\text { Size / Sch }\end{array}$ & $\begin{array}{l}\text { LENGTH } \\
\mathrm{ft}\end{array}$ & $\begin{array}{l}\text { FLUID } \\
\text { Temp / Pres }\end{array}$ & $\begin{array}{l}\text { VALVES } \\
\text { Total-K }\end{array}$ \\
\hline Pipe 0 & 03 & $\begin{array}{l}\text { Steel } \\
5 \text { in / } 40\end{array}$ & 0.442 & $\begin{array}{l}0 \% \text { solids } \\
70^{\circ} \mathrm{F} / 0 \text { psi g }\end{array}$ & 0.5 \\
\hline Pipe 1 & 03 & $\begin{array}{l}\text { Steel } \\
3 \text { in / } 40\end{array}$ & 2.323 & $\begin{array}{l}0 \% \text { solids } \\
70^{\circ} \mathrm{F} / 0 \text { psi g }\end{array}$ & 1.194 \\
\hline Pipe 2.1 & 03 & $\begin{array}{l}\text { Steel } \\
4 \text { in / } 40\end{array}$ & 26.049 & $\begin{array}{l}0 \% \text { solids } \\
70^{\circ} \mathrm{F} / 0 \text { psi g }\end{array}$ & 1.542 \\
\hline Pipe 2.2 & 03 & $\begin{array}{l}\text { Steel } \\
4 \text { in / } 40\end{array}$ & 18.673 & $\begin{array}{l}0 \% \text { solids } \\
70^{\circ} \mathrm{F} / 0 \text { psi g }\end{array}$ & 2.771 \\
\hline Pipe 2.3 & 03 & $\begin{array}{l}\text { Steel } \\
3 \text { in } / 40\end{array}$ & 0.667 & $\begin{array}{l}0 \% \text { solids } \\
70^{\circ} \mathrm{F} / 0 \text { psi g }\end{array}$ & 0.112 \\
\hline Pipe 3 & 03 & $\begin{array}{l}\text { Steel } \\
4 \text { in / } 40\end{array}$ & 6.787 & $\begin{array}{l}0 \% \text { solids } \\
70^{\circ} \mathrm{F} / 0 \text { psi g }\end{array}$ & 1.989 \\
\hline Pipe 4.1 & 03 & $\begin{array}{l}\text { Steel } \\
4 \text { in } / 40\end{array}$ & 822.8 & $\begin{array}{l}0 \% \text { solids } \\
70^{\circ} \mathrm{F} / 0 \text { psi g }\end{array}$ & 4.89 \\
\hline Pipe 4.2 & 03 & $\begin{array}{l}\text { Steel } \\
4 \text { in } / 40\end{array}$ & 468.1 & $\begin{array}{l}0 \% \text { solids } \\
70^{\circ} \mathrm{F} / 0 \mathrm{psi} \mathrm{g}\end{array}$ & 1.956 \\
\hline Pipe 4.3 & 03 & $\begin{array}{l}\text { Steel } \\
4 \text { in } / 40\end{array}$ & 428.7 & $\begin{array}{l}0 \% \text { solids } \\
70^{\circ} \mathrm{F} / 0 \text { psi g }\end{array}$ & 2.929 \\
\hline Pipe 4.4 & 03 & $\begin{array}{l}\text { Steel } \\
4 \text { in } / 40\end{array}$ & 26.268 & $\begin{array}{l}0 \% \text { solids } \\
70^{\circ} \mathrm{F} / 0 \text { psi g }\end{array}$ & 4.247 \\
\hline Pipe 5 & 03 & $\begin{array}{l}\text { Steel } \\
2.5 \text { in / } 40\end{array}$ & 1.231 & $\begin{array}{l}0 \% \text { solids } \\
70^{\circ} \mathrm{F} / 0 \text { psi g }\end{array}$ & 1.485 \\
\hline Pipe 6 & 03 & $\begin{array}{l}\text { Steel } \\
2 \text { in } / 40\end{array}$ & 0.667 & $\begin{array}{l}0 \% \text { solids } \\
70^{\circ} \mathrm{F} / 0 \text { psi g }\end{array}$ & 0.01334 \\
\hline Pipe 7 & 03 & $\begin{array}{l}\text { Steel } \\
2.5 \text { in / } 40\end{array}$ & 1.203 & $\begin{array}{l}0 \% \text { solids } \\
70^{\circ} \mathrm{F} / 0 \text { psi g }\end{array}$ & 0 \\
\hline Pipe 8 & 03 & $\begin{array}{l}\text { Steel } \\
2.5 \mathrm{in} / 40\end{array}$ & 0.604 & $\begin{array}{l}0 \% \text { solids } \\
70^{\circ} \mathrm{F} / 0 \text { psi g }\end{array}$ & 1.961 \\
\hline Pipe 9 & 04 & $\begin{array}{l}\text { Steel } \\
1 \text { in / } 80\end{array}$ & 0.271 & $\begin{array}{l}0 \% \text { solids } \\
70^{\circ} \mathrm{F} / 0 \mathrm{psi} \mathrm{g}\end{array}$ & 1 \\
\hline
\end{tabular}


Company: Fluor Daniel Northwest

Project: W-320 Anti-Siphon and Drainflow by: D. L. Stone

Created: 01/24/97 1:41 pm Design file:

Pipe Specs: 2
MATERIALS REPORT

03/17/97 3:07 pm

System: SIPHO\%1

rev: 03/17/97 2:34 pm
Pipes: 15

Nodes: 16

Pumps/Comps: 3

Supernate Line - 0\% Solids - Siphon Function (70F)

PIPE MATERIALS LIST

PIPELINE

Pipe 0

Pipe 1

Pipe 2.1

Pipe 2.2

Pipe 2.3

Pipe 3

03 Steel

4 in $/ 40$

Pipe 4.2

Pipe 4.3

Pipe 4.4

03

Steel
Pipe 4.1

4 in $/ 40$

LENGTH VALVES \& FITTINGS

0.442 1-Entrance Sharp-Edged

$2.3233-E l b o w$ Short - r/d $1 @ 90^{\circ}$ 1-Reducer Enlargement $4 \times 3$ 1-Reducer Contraction $5 \times 3$

$26.049 \quad$ 1-Elbow Short - r/d $1 @ 45^{\circ}$

4-Elbow Short - r/d $1 @ 90^{\circ}$

18.6734-Elbow Long - r/d 1.5@ 90

1-Elbow Short-r/d1@90

1-Mitre Bend @ 90

1-Fixed K 0.5546

0.667 1-Reducer Contraction $4 \times 3$

1-Reducer Enlargement $4 \times 3$

6.787

1-Mitre Bend @ 90

3-Elbow Long-r/d $1.5 @ 90^{\circ}$

1-Tee Flow Thru Run

822.8 10-Pipe Bend r/d $10 @ 90^{\circ}$

468.14-Pipe Bend r/d $10 @ 90^{\circ}$

$428.7 \quad 5-P i p e$ Bend $r / d 10 @ 90^{\circ}$

2-Pipe Bend r/d $8 @ 45^{\circ}$

26.2685-Elbow Long - r/d $1.5 @ 90^{\circ}$

2-Elbow Short - r/d $1 @ 45^{\circ}$

2-Mitre Bend @ 90

1 -Reducer Contraction $4 \times 2.5$

Pipe 5

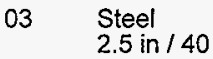

1.231

1-Elbow Short - r/d $1 @ 90^{\circ}$

1-Mitre Bend @ 90

1-Reducer Contraction $2.5 \times 2$ 
PIPELINE

Pipe 6

Pipe 7

Pipe 8

Pipe 9
SPEC MATERIAL Size / Sch

03 Steel

2 in $/ 40$

03 Steel

2.5 in $/ 40$

03 Steel

$2.5 \mathrm{in} / 40$

04 Steel

1 in $/ 80$
LENGTH VALVES \& FITTINGS

$\mathrm{ft}$

0.667 1-Reducer Enlargement $2.5 \times 2$

1.203

0.604

1-Reducer Contraction $2.5 \times 1$

$0.271 \quad$ 1-Exit Projecting 
PIPE SUMMARY

PIPE MATERIAL

Steel

Steel

SPECIFICATION

03 0\%-70F-sch 40

04 0\%-70F-sch 80
SCHEDULE SIZE

40

2 in

2.5 in

3 in

4 in

5 in

80

1 in
03/17/97 3:07 pm

LENGTH

$0.667 \mathrm{ft}$

$3.038 \mathrm{ft}$

$2.99 \mathrm{ft}$

$1797.38 \mathrm{ft}$

$0.442 \mathrm{ft}$

$0.271 \mathrm{ft}$

VALVE \& FITTING SUMMARY

Steel

Size: 2 in

Size: 2.5 in

Size: 3 in

Size: 4 in

Size: 5 in

MATERIAL

SCHEDULE VALVES \& FITTINGS

40

1-Reducer Enlargement $2.5 \times 2$

1-Elbow Short - r/d $1 @ 90^{\circ}$

1-Mitre Bend@90\%

1-Reducer Contraction $2.5 \times 2$

1-Reducer Contraction $2.5 \times 1$

3-Elbow Short - r/d $1 @ 90^{\circ}$

2-Reducer Enlargement $4 \times 3$

1-Reducer Contraction $5 \times 3$

1-Reducer Contraction $4 \times 3$

3-Elbow Short - r/d $1 @ 45^{\circ}$

5-Elbow Short - r/d $1 @ 90^{\circ}$

12-Elbow Long - r/d $1.5 @ 90^{\circ}$

4-Mitre Bend@90

1-Fixed K 0.5546

1-Tee Flow Thru Run

19-Pipe Bend r/d $10 @ 90^{\circ}$

2-Pipe Bend r/d $8 @ 45^{\circ}$

1-Reducer Contraction $4 \times 2.5$

1-Entrance Sharp-Edged

80

1-Exit Projecting 
Project: W-320 Anti-Siphon and Drainflow

PIPING MATERIAL: Steel

Schedule: 40

abs roughness: 0.0018 in

PIPE SIZE: 4 in dia: 4.026 in

LENGTH: $18.673 \mathrm{ft}$

ELEVATION in: $661.7 \mathrm{ft}$ out: $672.315 \mathrm{ft}$
PIPELINE REPORT

System: SIPHO\% 1

rev: 03/17/97 2:34 pm

Pipe 2.2 rev: 03/17/97 2:23 pm

SPECIFICATION: 0\%-70F-sch40

SIZING Criteria: $6 \mathrm{ft} / \mathrm{sec}$

LIMITS Velocity: 6 to $10 \mathrm{ft} / \mathrm{sec}$

Pressure: -14.4 to $300 \mathrm{psi} g$

FLUID $0 \%$ solids at tmp: $70^{\circ} \mathrm{F}$ pres: 0 psi $\mathrm{g}$ den: $62.31 \mathrm{lb} / \mathrm{ft}^{3}$ vsc: 3.96 cpois

$\begin{array}{llll}\begin{array}{l}\text { Flow } \\ \text { gpm }\end{array} & \text { ffp } & \begin{array}{l}\text { Vel } \\ \text { ft/sec }\end{array} & \begin{array}{l}\text { pp } \\ \text { psi }\end{array} \\ 75.41 & .0287 & 1.902 & 4.698 \\ 0 & .0000 & 0 & 4.592 \\ 33.04 & .0356 & 0.833 & 4.614 \\ 66.08 & .0297 & 1.667 & 4.674 \\ 99.12 & .0270 & 2.5 & 4.771 \\ 132.2 & .0254 & 3.333 & 4.904 \\ 165.2 & .0243 & 4.167 & 5.072 \\ 198.2 & .0234 & 5 & 5.275 \\ 231.3 & .0228 & 5.833 & 5.514 \\ 264.3 & .0223 & 6.667 & 5.788 \\ 297.4 & .0218 & 7.5 & 6.096 \\ 330.4 & .0215 & 8.333 & 6.44 \\ 363.4 & .0211 & 9.167 & 6.818 \\ 396.5 & .0209 & 10 & 7.231\end{array}$

PIPELINE RESISTANCE CURVE

VALVES and FITTINGS

VALVE / FITTING

Eibow Long - r/d $1.590^{\circ}$

Mitre Bend @ 90

K-VALUE VALVE/FITTING

K-VALUE

$4 @ 0.2282$

0.978

Elbow Short - r/d $190^{\circ}$

0.326

Fixed K

0.5546

FFT: 0.0163

TOTAL K: 2.771

Avg Percent of Total Loss: $67 \%$ 
Appendix $\mathrm{J}$

HNF-2477, Rev. 0

Page B-120 


\begin{tabular}{|c|c|c|}
\hline 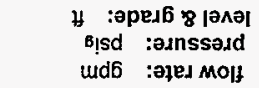 & 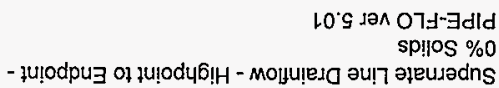 & :UO!sı \\
\hline L\%ONIbSO :dnau!7 & ShC auots 70 & \\
\hline $\begin{array}{l}\text { l\%ONIVYa : IS!|au!n } \\
\text { ud cl: }\end{array}$ & 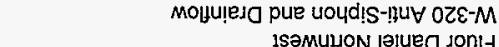 & : bolodd \\
\hline
\end{tabular}

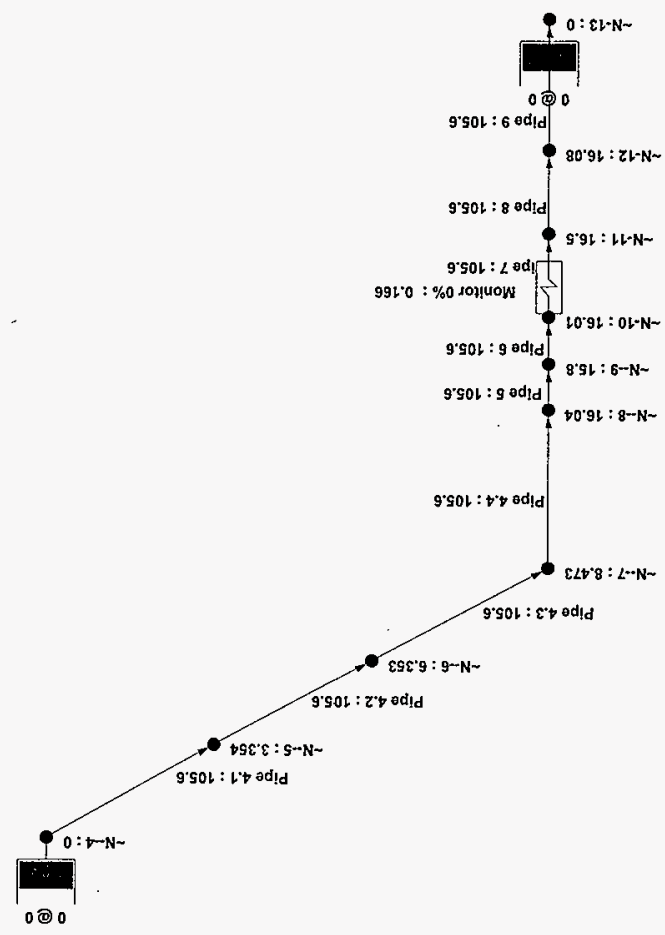


System: DRAIN0\%1

rev: 03/17/97 3:13 pm

Deviation: $0.000792 \%$ after: 4 iterations

Supernate Line - $0 \%$ solids - Time required to drain - Configuration 1: Source at Highpoint

Volumetric flow rates require constant fluid properties in all pipelines. Fluid properties in the first specification were used in this calculation.

LINEUP SUMMARIES

\section{PIPELINE}

Pipe 4.1

Pipe 9
FLOW gpm

$\ll \quad 105.6$

> 105.6

\section{PRESSURE} SOURCE

$\sim \mathrm{N}-4$

$\sim \mathrm{N}-13$

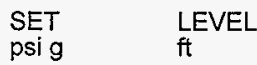

$0 \quad 0$

$0 \quad 0$

Flows IN: $105.6 \mathrm{gpm}$

Flows OUT: $105.6 \mathrm{gpm}$

NET FLOWS: 0 gpm 


$\begin{array}{lllll}\text { NODE } & \begin{array}{l}\text { ELEVATION } \\ \mathrm{ft}\end{array} & \begin{array}{l}\text { DEMAND } \\ \mathrm{gpm}\end{array} & \begin{array}{l}\text { PRESSURE } \\ \mathrm{psi} g\end{array} & \begin{array}{l}\text { H GRADE } \\ \mathrm{ft}\end{array} \\ \sim \mathrm{N}-4 & 677.11 & & 0 \text { (source) } & 677.1 \\ \sim \mathrm{N}-5 & 661.63 & & 3.354 & 669.4 \\ \sim \mathrm{N}--6 & 650.39 & & 6.353 & 665.1 \\ \sim \mathrm{N}--7 & 641.42 & 8.473 & 661 \\ \sim \mathrm{N}--8 & 623.217 & 16.04 & 660.3 \\ \sim \mathrm{N}--9 & 622.517 & 15.8 & 659 \\ \sim \mathrm{N}-10 & 621.85 & 16.01 & 658.9 \\ \sim \mathrm{N}-11 & 620.225 & 16.5 & 658.4 \\ \sim \mathrm{N}-12 & 619.621 & 16.08 & 656.8 \\ \sim \mathrm{N}-13 & 619.35 & 0 \text { (source) } & 619.3\end{array}$




\begin{tabular}{|c|c|c|c|c|c|c|}
\hline PIPELINE & FROM & TO & $\begin{array}{l}\text { FLOW } \\
\text { gom }\end{array}$ & $\begin{array}{l}\text { VEL } \\
\mathrm{ft} / \mathrm{sec}\end{array}$ & $\begin{array}{l}\mathrm{dP} \\
\text { psig }\end{array}$ & $\begin{array}{l}\mathrm{HL} \\
\mathrm{ft}\end{array}$ \\
\hline se 4.1 & $\sim N-4$ & $\sim N-5$ & 105.6 & *2.664 & (3.354) & 7.725 \\
\hline Pipe 4.2 & $\sim N--5$ & $\sim N--6$ & 105.6 & * 2.664 & (2.999) & 4.304 \\
\hline ipe 4.3 & $\sim N--6$ & $\sim N-7$ & 105.6 & * 2.664 & $(2.12)$ & 4.067 \\
\hline ipe 4.4 & $\sim N--7$ & $\sim N--8$ & 105.6 & *2.664 & $(7.571)$ & 0.697 \\
\hline ipe 5 & $\sim N--8$ & $\sim N--9$ & 105.6 & 7.084 & 0.247 & 1.272 \\
\hline Pipe 6 & $\sim N--9$ & $\sim \mathrm{N}-10$ & 105.6 & * 10.11 & $(0.214)$ & 0.172 \\
\hline Pipe 7 & $\begin{array}{l}\sim N-10 \\
--d P\end{array}$ & $\mathrm{HL}: \tilde{\sim N}^{\sim \mathrm{N}-11}$ & 105.6 & 7.084 & $(0.488)$ & 0.498 \\
\hline Pipe 8 & $\sim N-11$ & $\sim N-12$ & 105.6 & 7.084 & 0.423 & 1.583 \\
\hline Pipe 9 & $\sim N-12$ & $\sim N-13$ & 105.6 & * 47.15 & 16.08 & 37.44 \\
\hline
\end{tabular}




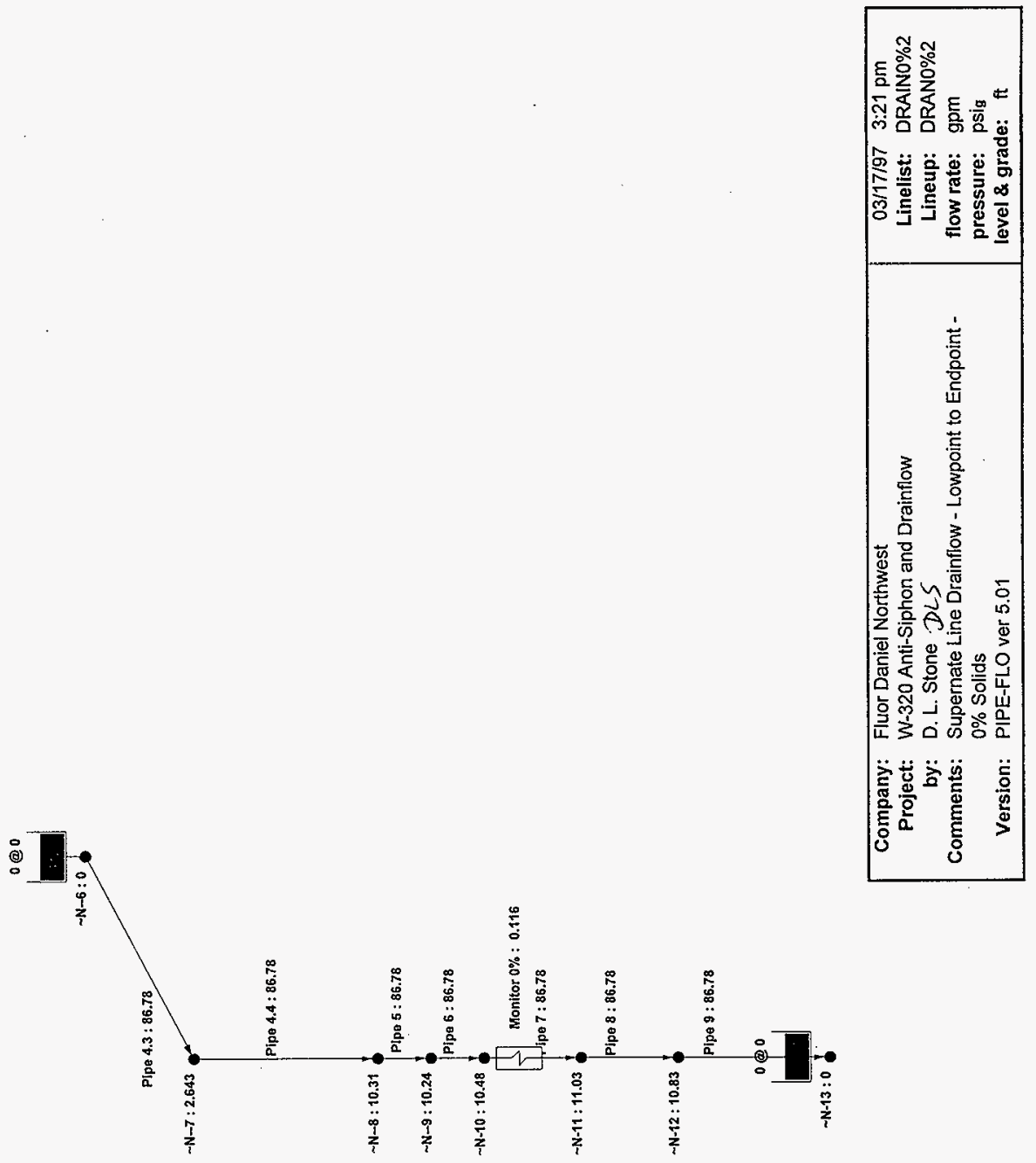

HNF-2477, Rev. 0 
Supernate Line Drainflow - $0 \%$ solids - Source at Stationpoint

Volumetric flow rates require constant fluid properties in all pipelines. Fluid properties in the first specification were used in this calculation.

\section{LINEUP SUMMARIES}

PIPELINE

Pipe 4.3

Pipe 9

\section{FLOW} gpm

$\ll 86.78$

$\gg>86.78$
PRESSURE SOURCE

$\sim \mathrm{N}-6$

$\sim N-13$

\section{SET}

psig

0

0
LEVEL

0

0

Flows IN: $86.78 \mathrm{gpm}$

Flows OUT: $86.78 \mathrm{gpm}$

NET FLOWS: $0 \mathrm{gpm}$ 


$\begin{array}{lllll}\text { NODE } & \begin{array}{l}\text { ELEVATION } \\ \mathrm{ft}\end{array} & \begin{array}{l}\text { DEMAND } \\ \mathrm{gpm}\end{array} & \begin{array}{l}\text { PRESSURE } \\ \text { psi g }\end{array} & \begin{array}{l}\text { H GRADE } \\ \mathrm{ft}\end{array} \\ \sim \mathrm{N}-6 & 650.39 & & 0 \text { (source) } & 650.4 \\ \sim \mathrm{N}-\mathrm{-7} & 641.42 & & 2.643 & 647.5 \\ \sim \mathrm{N}-\mathrm{-8} & 623.217 & & 10.31 & 647.1 \\ \sim \mathrm{N}-9 & 622.517 & & 10.24 & 646.2 \\ \sim \mathrm{N}-10 & 621.85 & & 10.48 & 646.1 \\ \sim \mathrm{N}-11 & 620.225 & 11.03 & 645.7 \\ \sim \mathrm{N}-12 & 619.621 & 10.83 & 644.7 \\ \sim \mathrm{N}-13 & 619.35 & & 0 \text { (source) } & 619.3\end{array}$




\begin{tabular}{|c|c|c|c|c|c|c|}
\hline PIPELINE & FROM & TO & $\begin{array}{l}\text { FLOW } \\
\text { gpm }\end{array}$ & $\begin{array}{l}\text { VEL } \\
\mathrm{ft} / \mathrm{sec}\end{array}$ & $\begin{array}{l}\mathrm{dP} \\
\text { psig }\end{array}$ & $\underset{\mathrm{ft}}{\mathrm{HL}}$ \\
\hline ye 4.3 & $\sim N-6$ & $\sim N-7$ & 86.78 & * 2.189 & $(2.643)$ & 2.859 \\
\hline ipe 4.4 & $\sim N-7$ & $\sim N-8$ & 86.78 & $\star 2.189$ & $(7.666)$ & 0.478 \\
\hline ipe 5 & $\sim N--8$ & $\sim N--9$ & 86.78 & * 5.82 & 0.070 & 0.861 \\
\hline Pipe 6 & $\sim N--9$ & $\sim N-10$ & 86.78 & 8.304 & $(0.237)$ & 0.119 \\
\hline Pipe 7 & $\begin{array}{l}\sim \mathrm{N}-10 \\
--\mathrm{dP}\end{array}$ & $H L: 0.268^{\sim N-11}$ & 86.78 & * 5.82 & $(0.553)$ & 0.347 \\
\hline ipe 8 & $\sim N-11$ & $\sim N-12$ & 86.78 & * 5.82 & 0.202 & 1.07 \\
\hline pe 9 & $\sim \mathrm{N}-12$ & $\sim N-13$ & 86.78 & * 38.74 & 10.83 & 25.31 \\
\hline
\end{tabular}


Appendix K

HNF-2477, Rev. 0

Page B-129 
System: SIPH10\%1

rev: $03 / 17 / 97 \cdot 2: 52 \mathrm{pm}$

Deviation: $0.007 \%$ after: 6 iterations

Supernate Line - $10 \%$ solids - Siphon Function

Volumetric flow rates require constant fluid properties in all pipelines. Fluid properties in the first specification were used in this calculation.

LINEUP SUMMARIES

PIPELINE

Pipe 0

Pipe 9

\section{FLOW} gpm

$\ll 71.98$

$\gg 71.98$

\section{PRESSURE} SOURCE

$\sim \mathrm{N}-\mathrm{-}$

$\sim \mathrm{N}-13$

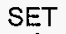

psi g

0

0

Flows IN: $71.98 \mathrm{gpm}$

Flows OUT: $71.98 \mathrm{gpm}$

NET FLOWS: $0 \mathrm{gpm}$ 
NODE

$\sim \mathrm{N}-\mathrm{O}$

$\sim \mathrm{N}-1$

$\sim \mathrm{N}-2.1$

$\sim \mathrm{N}-2.2$

$\sim N-2.3$

$\sim \mathrm{N}-\mathrm{3}$

$\sim \mathrm{N}-4$

$\sim N-5$

$\sim N-6$

$\sim \mathrm{N}-\mathrm{-7}$

$\sim \mathrm{N}-\mathrm{-8}$

$\sim N--9$

$\sim \mathrm{N}-10$

$\sim \mathrm{N}-11$

$\sim \mathrm{N}-12$

$\sim N-13$

\section{ELEVATION \\ $\mathrm{ft}$ \\ DEMAND
$\mathrm{gpm}$}

635.5

635.943

637.338

661.7

672.315

672.669

677.11

661.63

650.39

641.42

623.217

622.517

621.85

620.225

619.621

619.35
PRESSURE

psi g

8.795 (source) $\quad 653.7$

8.575

7.543

$-4.368$

$-9.629$

$-11.03$

$-13.25$

$-8.214$

$-4.153$

$-1.109$

7.527

7.57

7.843

8.477

8.409

0 (source)
H GRADE

$\mathrm{ft}$

653.6

652.9

652.7

652.4

649.9

649.8

644.7

641.8

639.1

638.8

638.1

638

637.7

637

619.3 


\begin{tabular}{|c|c|c|c|c|c|c|}
\hline PIPELINE & FROM & TO & $\begin{array}{l}\text { FLOW } \\
\text { gpm }\end{array}$ & $\begin{array}{l}\text { VEL } \\
\mathrm{ft} / \mathrm{sec}\end{array}$ & $\begin{array}{l}d P \\
\text { psi g }\end{array}$ & $\begin{array}{l}\mathrm{HL} \\
\mathrm{ft}\end{array}$ \\
\hline je 0 & $\sim N--0$ & $\sim N-1$ & 71.98 & * 1.155 & 0.220 & 0.011 \\
\hline Pipe 1 & $\begin{array}{l}\sim \mathrm{N}-\mathrm{-1} \\
\therefore \mathrm{dP}: 0.245\end{array}$ & $\mathrm{HL}: \quad \sim^{\sim \mathrm{N}--2.1}$ & 71.98 & * 3.126 & 1.032 & 0.736 \\
\hline Pipe 2.1 & $\sim N--2.1$ & $\sim N--2.2$ & 71.98 & $* 1.816$ & 11.91 & 0.232 \\
\hline Pipe 2.2 & $\sim N--2.2$ & $\sim N--2.3$ & 71.98 & $\star 1.816$ & 5.261 & 0.249 \\
\hline Pipe 2.3 & $\begin{array}{l}\sim N--2.3 \\
--d P: 1.211\end{array}$ & $H L: \sim^{\sim N-501}$ & 71.98 & * 3.126 & 1.398 & 2.532 \\
\hline Pipe 3 & $\sim N--3$ & $\sim N-4$ & 71.98 & * 1.816 & 2.219 & 0.142 \\
\hline Pipe 4.1 & $\sim N--4$ & $\sim N--5$ & 71.98 & $* 1.816$ & $(5.032)$ & 5.09 \\
\hline Pipe 4.2 & $\sim N--5$ & $\sim N--6$ & 71.98 & * 1.816 & $(4.062)$ & 2.853 \\
\hline Pipe 4.3 & $\sim N--6$ & $\sim N-7$ & 71.98 & * 1.816 & $(3.043)$ & 2.687 \\
\hline Pipe 4.4 & $\sim N--7$ & $\sim N-8$ & 71.98 & $* 1.816$ & $(8.636)$ & 0.372 \\
\hline Pipe 5 & $\sim N--8$ & $\sim N \sim 9$ & 71.98 & $\star 4.827$ & $(0.043)$ & 0.611 \\
\hline Pipe 6 & $\sim N--9$ & $\sim N-10$ & 71.98 & 6.888 & $(0.273)$ & 0.103 \\
\hline Pipe 7 & $\begin{array}{l}\sim N-10 \\
-\cdots d P: 0.118\end{array}$ & $\mathrm{HL}: \quad 0.244^{-11}$ & 71.98 & * 4.827 & $(0.634)$ & 0.316 \\
\hline Pipe 8 & $\sim N-11$ & $\sim N-12$ & 71.98 & * 4.827 & 0.068 & 0.745 \\
\hline Pipe 9 & $\sim N-12$ & $\sim N-13$ & 71.98 & $* 32.13$ & 8.409 & 17.63 \\
\hline
\end{tabular}


Company: Fluor Daniel Northwest

Project: W-320 Anti-Siphon and Drainflow by: D. L. Stone

Created: 01/24/97 1:41 pm

SYSTEM REPORT

Design file:

Pipe Specs: 2
03/17/97 3:04 pm

System: SIPH10\%1

rev: 03/17/97 2:52 pm

Pipes: 15

Nodes: 16

Pumps/Comps: 3

Supernate Line - $10 \%$ Solids - Siphon Function (70F)

SYSTEM NODES

NODE

$\sim N--0$

$\sim \mathrm{N}-1$

$\sim \mathrm{N}-2.1$

$\sim \mathrm{N}-2.2$

$\sim N-2.3$

$\sim N-3$

$\sim \mathrm{N}-\mathrm{-4}$

$\sim \mathrm{N}-\mathrm{-5}$

$\sim N--6$

$\sim N--7$

$\sim N--8$

$\sim \mathrm{N}-\mathrm{-9}$

$\sim N-10$

$\sim N-11$

$\sim N-12$

$\sim N-13$
ELEVATION

$\mathrm{ft}$

635.5

635.943

637.338

661.7

672.315

672.669

677.11

661.63

650.39

641.42

623.217

622.517

621.85

620.225

619.621

619.35
PIPELINES IN

PIPELINES OUT

Pipe 0

Pipe 0

Pipe 1

Pipe 2.1

Pipe 2.2

Pipe 2.3

Pipe 3

Pipe 4.1

Pipe 4.2

Pipe 4.3

Pipe 4.4

Pipe 5

Pipe 6

Pipe 7

Pipe 8

Pipe 9
Pipe 1

Pipe 2.1

Pipe 2.2

Pipe 2.3

Pipe 3

Pipe 4.1

Pipe 4.2

Pipe 4.3

Pipe 4.4

Pipe 5

Pipe 6

Pipe 7

Pipe 8

Pipe 9 


$\begin{array}{lllll}\text { PIPELINE } & \text { SPEC } & \text { FROM_NODE } & \text { TO_NODE } & \text { PUMP/COMP } \\ \text { Pipe 0 } & 05 & \sim N--0 & \sim N--1 & \text { Pos Flow } 1 \\ \text { Pipe 1 } & 05 & \sim N-1 & \sim N--2.1 & \\ \text { Pipe 2.1 } & 05 & \sim N--2.1 & \sim N--2.2 & \\ \text { Pipe 2.2 } & 05 & \sim N-2.2 & \sim N--2.3 & \text { Pos Flow 2 } \\ \text { Pipe 2.3 } & 05 & \sim N--2.3 & \sim N-4 & \\ \text { Pipe 3 } & 05 & \sim N--3 & \sim N--5 & \\ \text { Pipe 4.1 } & 05 & \sim N--4 & \sim N--6 & \\ \text { Pipe 4.2 } & 05 & \sim N--5 & \sim N--7 & \\ \text { Pipe 4.3 } & 05 & \sim N-6 & \sim N--8 & \\ \text { Pipe 4.4 } & 05 & \sim N-7 & \sim N--9 & \text { Monitor 10\% } \\ \text { Pipe 5 } & 05 & \sim N--8 & \sim N-10 & \\ \text { Pipe 6 } & 05 & \sim N--9 & \sim N-11 & \\ \text { Pipe 7 } & 05 & \sim N-10 & \sim N-12 & \\ \text { Pipe 8 } & 05 & \sim N-11 & \sim N-13 & \\ \text { Pipe 9 } & 02 & \sim N-12 & & \end{array}$


PUMP/COMP

Monitor $10 \%$

Pos Flow 1

Pos Flow 2

PERFORMANCE DATA

\begin{tabular}{llllll} 
gpm: & 0 & 50 & 150 & 250 & 350 \\
ft: & 0 & 0.13 & 0.87 & 2.18 & 4.04 \\
eqn: & \multicolumn{2}{l}{$0.000130185 \mathrm{Q} \wedge 1.7625$} & & &
\end{tabular}

$\begin{array}{llllll}\text { gpm: } & 0 & 40 & 80 & 120 & 150 \\ \mathrm{ft}: & 0 & 0.156 & 0.624 & 1.4 & 2.2\end{array}$

eqn: $\quad 9.72278 \mathrm{e}-005 \mathrm{Q}^{\wedge} 2.00063$

$\begin{array}{llllll}\text { gpm: } & 0 & 40 & 80 & 120 & 150 \\ \mathrm{ft:} & 0 & 0.77 & 3.08 & 7 & 10.9\end{array}$

eqn: $\quad 0.000468926 Q^{\wedge} 2.00674$ 
Company: Fluor Daniel Northwest

Project: W-320 Anti-Siphon and Drainflow by: D. L. Stone

Created: 01/24/97 1:41 pm

Design file:

Pipe Specs: 2
PIPELIST REPORT

03/17/97 3:04 pm

System: SIPH10\%1

rev: $03 / 17 / 97$ 2:52 pm

Pipes: 15

Nodes: 16

Pumps/Comps: 3

Supernate Line - 10\% Solids - Siphon Function (70F)

SPECIFICATIONS

\begin{tabular}{|c|c|c|c|c|}
\hline SPECIFICATION & $\begin{array}{l}\text { PIPE MATERIAL } \\
\text { Sch / Roughness }\end{array}$ & $\begin{array}{l}\text { FLUID } \\
\text { Temp / Pres }\end{array}$ & VALVE TABLE & $\begin{array}{l}\text { DESIGN LIMITS } \\
\text { Vel / Pres }\end{array}$ \\
\hline \multirow[t]{2}{*}{$\begin{array}{l}0510 \%-\operatorname{sch} 40 \\
\text { rev: } 02 / 25 / 97 \quad 7: 03 \mathrm{am}\end{array}$} & $\begin{array}{l}\text { Steel } \\
\text { Sch } 40 \\
0.0018 \text { in }\end{array}$ & $\begin{array}{l}10 \% \text { solids } \\
70^{\circ} \mathrm{F} \\
0 \text { psi g }\end{array}$ & Standard & $\begin{array}{l}6-10 \mathrm{ft} / \mathrm{sec} \\
-14.4-300 \text { psi g }\end{array}$ \\
\hline & Size for: $6 \mathrm{ft} / \mathrm{sec}$ & & & \\
\hline $\begin{array}{l}0210 \%-s c h 80 \\
\text { rev: } 02 / 25 / 97 \quad 7: 03 \mathrm{am}\end{array}$ & $\begin{array}{l}\text { Steel } \\
\text { Sch } 80 \\
0.0018 \text { in }\end{array}$ & $\begin{array}{l}10 \% \text { solids } \\
70^{\circ} \mathrm{F} \\
0 \mathrm{psig}\end{array}$ & Standard & $\begin{array}{l}6-10 \mathrm{ft} / \mathrm{sec} \\
-14.4-300 \text { psi g }\end{array}$ \\
\hline
\end{tabular}

Size for: $6 \mathrm{ft} / \mathrm{sec}$ 


\begin{tabular}{|c|c|c|c|c|c|}
\hline PIPELINE & SPEC & $\begin{array}{l}\text { MATERIAL } \\
\text { Size / Sch }\end{array}$ & $\begin{array}{l}\text { LENGTH } \\
\mathrm{ft}\end{array}$ & $\begin{array}{l}\text { FLUID } \\
\text { Temp / Pres }\end{array}$ & $\begin{array}{l}\text { VALVES } \\
\text { Total-K }\end{array}$ \\
\hline Pipe 0 & 05 & $\begin{array}{l}\text { Steel } \\
5 \text { in / } 40\end{array}$ & 0.442 & $\begin{array}{l}10 \% \text { solids } \\
70 \% \text { F } 0 \text { psi g }\end{array}$ & 0.5 \\
\hline Pipe 1 & 05 & $\begin{array}{l}\text { Steel } \\
3 \mathrm{in} / 40\end{array}$ & 2.323 & $\begin{array}{l}10 \% \text { solids } \\
70^{\circ} \mathrm{F} / 0 \text { psi g }\end{array}$ & 1.194 \\
\hline Pipe 2.1 & 05 & $\begin{array}{l}\text { Steel } \\
4 \text { in } / 40\end{array}$ & 26.049 & $\begin{array}{l}10 \% \text { solids } \\
70^{\circ} \mathrm{F} / 0 \text { psi g }\end{array}$ & 1.542 \\
\hline Pipe 2.2 & 05 & $\begin{array}{l}\text { Steel } \\
4 \text { in } / 40\end{array}$ & 18.673 & $\begin{array}{l}10 \% \text { solids } \\
70{ }^{\circ} \mathrm{F} / 0 \text { psi g }\end{array}$ & 2.712 \\
\hline Pipe 2.3 & 05 & $\begin{array}{l}\text { Steel } \\
3 \text { in } / 40\end{array}$ & 0.667 & $\begin{array}{l}10 \% \text { solids } \\
70 \% \text { F } / 0 \text { psi g }\end{array}$ & 0.112 \\
\hline Pipe 3 & 05 & $\begin{array}{l}\text { Steel } \\
4 \text { in } / 40\end{array}$ & 6.787 & $\begin{array}{l}10 \% \text { solids } \\
70^{\circ} \mathrm{F} / 0 \mathrm{psig}\end{array}$ & 1.989 \\
\hline Pipe 4.1 & 05 & $\begin{array}{l}\text { Steel } \\
4 \text { in } / 40\end{array}$ & 822.8 & $\begin{array}{l}10 \% \text { solids } \\
70{ }^{\circ} \mathrm{F} / 0 \text { psi g }\end{array}$ & 4.89 \\
\hline Pipe 4.2 & 05 & $\begin{array}{l}\text { Steel } \\
4 \text { in } / 40\end{array}$ & 468.1 & $\begin{array}{l}10 \% \text { solids } \\
70{ }^{\circ} \mathrm{F} / 0 \text { psi g }\end{array}$ & 1.956 \\
\hline Pipe 4.3 & 05 & $\begin{array}{l}\text { Steel } \\
4 \text { in } / 40\end{array}$ & 428.7 & $\begin{array}{l}10 \% \text { solids } \\
70^{\circ} \mathrm{F} / 0 \text { psi g }\end{array}$ & 3.227 \\
\hline Pipe 4.4 & 05 & $\begin{array}{l}\text { Steel } \\
4 \text { in } / 40\end{array}$ & 26.268 & $\begin{array}{l}10 \% \text { solids } \\
70{ }^{\circ} \mathrm{F} / 0 \text { psi g }\end{array}$ & 4.247 \\
\hline Pipe 5 & 05 & $\begin{array}{l}\text { Steel } \\
2.5 \mathrm{in} / 40\end{array}$ & 1.231 & $\begin{array}{l}10 \% \text { solids } \\
70^{\circ} \mathrm{F} / 0 \text { psi g }\end{array}$ & 1.485 \\
\hline Pipe 6 & 05 & $\begin{array}{l}\text { Steel } \\
2 \text { in } / 40\end{array}$ & 0.667 & $\begin{array}{l}10 \% \text { solids } \\
70{ }^{\circ} \mathrm{F} / 0 \text { psi g }\end{array}$ & 0.01334 \\
\hline Pipe 7 & 05 & $\begin{array}{l}\text { Steel } \\
2.5 \text { in / } 40\end{array}$ & 1.203 & $\begin{array}{l}10 \% \text { solids } \\
70{ }^{\circ} \mathrm{F} / 0 \text { psi g }\end{array}$ & 0 \\
\hline Pipe 8 & 05 & $\begin{array}{l}\text { Steel } \\
2.5 \text { in / } 40\end{array}$ & 0.604 & $\begin{array}{l}10 \% \text { solids } \\
70 \% \text { F / } 0 \text { psi g }\end{array}$ & 1.961 \\
\hline Pipe 9 & 02 & $\begin{array}{l}\text { Steel } \\
1 \text { in } / 80\end{array}$ & 0.271 & $\begin{array}{l}10 \% \text { solids } \\
70^{\circ} \mathrm{F} / 0 \text { psi g }\end{array}$ & 1 \\
\hline
\end{tabular}


Company: Fluor Daniel Northwest

Project: W-320 Anti-Siphon and Drainflow by: D. L. Stone

Created: 01/24/97 1:41 pm

MATERIALS REPORT

Design file:

Pipe Specs: 2
03/17/97 3:04 pm

System: SIPH10\%1

rev: 03/17/97 2:52 pm
Pipes: 15

Nodes: 16

Pumps/Comps: 3

Supernate Line - $10 \%$ Solids - Siphon Function (70F)

PIPE MATERIALS LIST

PIPELINE

Pipe 0

Pipe 1

Pipe 2.1

Pipe 2.2

Dipe 2.3

Pipe 3

Pipe 4.1

Pipe 4.2

Pipe 4.3

Pipe 4.4

05

Steel

4 in $/ 40$

Pipe 5

05

05 Steel

05 Steel

$4 \mathrm{in} / 40$

05 Steel

3 in $/ 40$

05 Steel

4 in $/ 40$

05 Steel

4 in $/ 40$

05 Steel

4 in $/ 40$

05 Steel

4 in $/ 40$

\section{SPEC MATERIAL Size / Sch \\ 05}

4 in $/ 40$

428.7

26.268

5-Elbow Long - r/d $1.5 @ 90^{\circ}$

2-Elbow Short - r/d $1 @ 45^{\circ}$

2-Mitre Bend @ 90

1-Reducer Contraction $4 \times 2.5$

1.231

$05 \quad$ Steel $/ 40$

-Elbow Short - r/d $1 @ 90^{\circ}$

1-Reducer Contraction $5 \times 3$

1-Elbow Short-r/d $1 @ 45^{\circ}$

4-Elbow Short-r/d $1 @$ @ 90

4-Elbow Long - r/d 1.5@ 90

1-Elbow Short - r/d $1 @ 90^{\circ}$

1-Mitre Bend@90

1-Fixed K 0.4952

1-Reducer Contraction $4 \times 3$ 1-Reducer Enlargement $4 \times 3$

1-Mitre Bend @ $90^{\circ}$

3-Elbow Long - r/d $1.5 @ 90^{\circ}$

1-Tee Flow Thru Run

10-Pipe Bend r/d 10 @ 90

4-Pipe Bend r/d $10 @ 90^{\circ}$

5-Pipe Bend r/d $10 @ 90^{\circ}$

2-Pipe Bend r/d $8 @ 90^{\circ}$
1-Elbow Short - r/d $1 @ 90^{\circ}$

1-Mitre Bend @ 90

1-Reducer Contraction $2.5 \times 2$ 


\section{PIPE MATERIALS LIST $\quad 03 / 17 / 97 \quad 3: 04$ pm}

PIPELINE

Pipe 6

Pipe 7

Pipe 8

Pipe 9
SPEC MATERIAL.

Size / Sch

05 Steel

2 in $/ 40$

05 Steel

$2.5 \mathrm{in} / 40$

05 Steel

2.5 in $/ 40$

02 Steel

4 in $/ 80$
LENGTH VALVES \& FITTINGS $\mathrm{ft}$

0.667 1-Reducer Enlargement $2.5 \times 2$

1.203

$0.604 \quad$ 1-Reducer Contraction $2.5 \times 1$

$0.271 \quad 1$-Exit Projecting 
PIPE SUMMARY

PIPE MATERIAL

Steel

Steel

\section{SPECIFICATION}

$0510 \%$-sch 40

$0210 \%-\operatorname{sch} 80$
MATERIAL

Steel

Size: 2 in

Size: 2.5 in

Size: 3 in

Size: 4 in

Size: 5 in

Steel

Size: 1 in
SCHEDULE SIZE

40

80

2 in

2.5 in

3 in

4 in

5 in

1 in
03/17/97 3:04 pm

LENGTH

$0.271 \mathrm{ft}$

\section{VALVE \& FITTING SUMMARY}

\section{SCHEDULE VALVES \& FITTINGS}

40

1-Reducer Enlargement $2.5 \times 2$

1-Elbow Short - r/d $1 @ 90^{\circ}$

1-Mitre Bend @ $90^{\circ}$

1-Reducer Contraction $2.5 \times 2$

1-Reducer Contraction $2.5 \times 1$

3-Elbow Short - r/d $1 @ 90^{\circ}$

2-Reducer Enlargement $4 \times 3$

1-Reducer Contraction $5 \times 3$

1-Reducer Contraction $4 \times 3$

3-Elbow Short-r/d $1 @ 45^{\circ}$

5-Elbow Short - r/d $1 @ 90^{\circ}$

12-Elbow Long - r/d $1.5 @ 90^{\circ}$

4-Mitre Bend @ 90

1-Fixed K 0.4952

1-Tee Flow Thru Run

19-Pipe Bend r/d $10 @ 90^{\circ}$

2-Pipe Bend r/d $8 @ 90^{\circ}$

1-Reducer Contraction $4 \times 2.5$

1-Entrance Sharp-Edged

80

1-Exit Projecting 
Company: Fluor Daniel Northwest

Project: W-320 Anti-Siphon and Drainflow by: D. L. Stone

PIPING MATERIAL: Steel Schedule: 40 abs roughness: 0.0018 in

PIPE SIZE: 4 in dia: 4.026 in LENGTH: $18.673 \mathrm{ft}$ ELEVATION in: $661.7 \mathrm{ft}$ out: $672.315 \mathrm{ft}$
PIPELINE REPORT

Pipe 2.2 rev: 03/17/97 2:46 pm

SPECIFICATION: $10 \%$-sch 40

SIZING Criteria: $6 \mathrm{ft} / \mathrm{sec}$

LIMITS Velocity: 6 to $10 \mathrm{ft} / \mathrm{sec}$ Pressure: -14.4 to $300 \mathrm{psi} \mathrm{g}$

FLUID $10 \%$ solids at tmp: $70^{\circ} \mathrm{F}$ pres: 0 psi g den: $69.78 \mathrm{lb} / \mathrm{t}^{3}$ vsc: 12.87 cpois

\section{PIPELINE RESISTANCE CURVE}

$\begin{array}{llll}\begin{array}{l}\text { Flow } \\ \text { gpm }\end{array} & \text { ffp } & \begin{array}{l}\text { Vel } \\ \text { ft/sec }\end{array} & \begin{array}{l}\text { dP } \\ \text { psi }\end{array} \\ 71.98 & .0386 & 1.816 & 5.263 \\ 0 & .0000 & 0 & 5.142 \\ 33.04 & .0494 & 0.833 & 5.171 \\ 66.08 & .0396 & 1.667 & 5.245 \\ 99.12 & .0352 & 2.5 & 5.362 \\ 132.2 & .0326 & 3.333 & 5.52 \\ 165.2 & .0308 & 4.167 & 5.72 \\ 198.2 & .0294 & 5 & 5.959 \\ 231.3 & .0284 & 5.833 & 6.239 \\ 264.3 & .0275 & 6.667 & 6.559 \\ 297.4 & .0268 & 7.5 & 6.919 \\ 330.4 & .0262 & 8.333 & 7.318 \\ 363.4 & .0257 & 9.167 & 7.756 \\ 396.5 & .0252 & 10 & 8.234\end{array}$

VALVE / FITTING

VALVES and FITTINGS

Elbow Long - r/d $1.590^{\circ}$ Mitre Bend @ $90^{\circ}$

K-VALUE 4@0.2282 0.978

TOTAL K: 2.712
VALVE / FITTING

Elbow Short - r/d $190^{\circ}$ Fixed K
K-VALUE

0.326

0.4952

FFT: 0.0163

Avg Percent of Total Loss: $61 \%$ 


\section{Appendix $\mathrm{L}$}




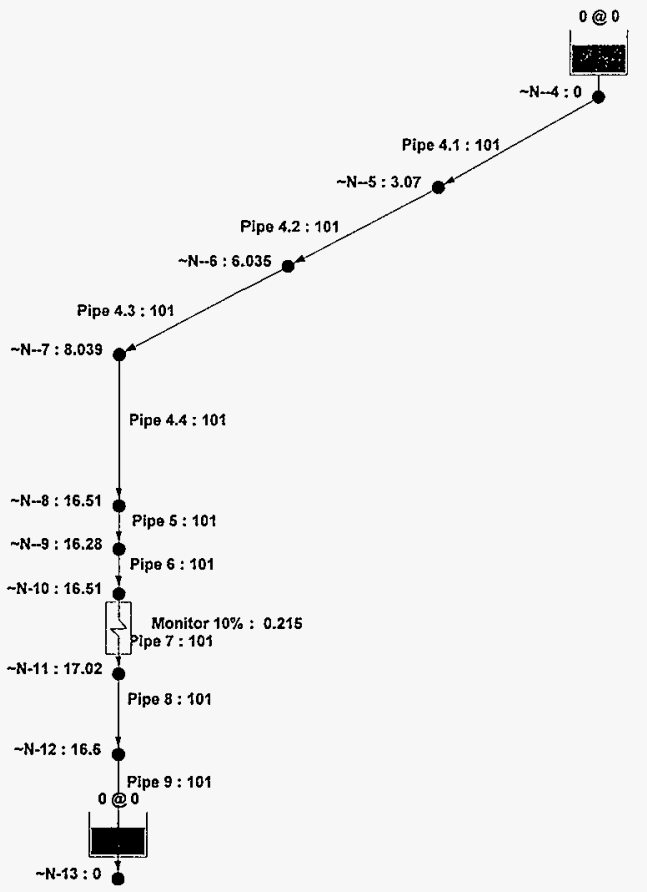

$\begin{aligned} \text { Company: } & \text { Fluor Daniel Northwest } \\ \text { Project: } & \text { W-320 Anti-Siphon and Drainflow } \\ \text { by: } & \text { D. L. Stone D } \text { LS } \\ \text { Comments: } & \text { Supernate Line Drainflow - Highpoint to Endpoint - } \\ & 10 \% \text { Solids } \\ \text { Version: } & \text { PIPE-FLO ver } 5.01\end{aligned}$

$03 / 17 / 97 \quad 3: 30 \mathrm{pm}$

Linelist: DRAN10\%1

Lineup: DRAIN0\%1

flow rate: gpm

pressure: psig level \& grade: $\mathrm{ft}$ 
System: DRAN10\%1

rev: 03/17/97 3:28 pm

Deviation: $0.00272 \%$ after: 3 iterations

Supernate Line - $0 \%$ solids - Time required to drain - Configuration 1: Source at Highpoint

Volumetric flow rates require constant fluid properties in all pipelines. Fluid properties in the first specification were used in this calculation.

LINEUP SUMMARIES

PIPELINE

Pipe 4.1

Pipe 9

\section{FLOW}

gpm

$\ll \quad 101$

$\gg 101$
PRESSURE
SOURCE

$\sim N-4$

$\sim \mathrm{N}-13$

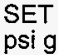

psi g

0

0

0

Flows IN: $101 \mathrm{gpm}$

Flows OUT: $101 \mathrm{gpm}$

NET FLOWS: 0 gpm 
NODE

$\sim N-4$

$\sim \mathrm{N}-\mathrm{-5}$

$\sim N-6$

$\sim \mathrm{N}-7$

$\sim \mathrm{N}-\mathrm{-8}$

$\sim \mathrm{N}-\mathrm{9}$

$\sim N-10$

$\sim \mathrm{N}-11$

$\sim \mathrm{N}-12$

$\sim \mathrm{N}-13$

$\begin{array}{ll}\text { ELEVATION } & \begin{array}{l}\text { DEMAND } \\ \mathrm{ft}\end{array} \\ \mathrm{gpm}\end{array}$

677.11

661.63

650.39

641.42

623.217

622.517

621.85

620.225

619.621

619.35
PRESSURE

psig

0 (source)

3.07

6.035

8.039

16.51

16.28

16.51

17.02

16.6

0 (source)
H GRADE

677.1

668

662.9

658

657.3

656.1

655.9

655.4

653.9

619.3 


\begin{tabular}{|c|c|c|c|c|c|c|}
\hline PIPELINE & FROM & TO & $\begin{array}{l}\text { FLOW } \\
\text { gpm }\end{array}$ & $\begin{array}{l}\text { VEL } \\
\mathrm{ft} / \mathrm{sec}\end{array}$ & $\begin{array}{l}\text { dP } \\
\text { psig }\end{array}$ & $\begin{array}{l}\mathrm{HL} \\
\mathrm{ft}\end{array}$ \\
\hline ye 4.1 & $\sim N--4$ & $\sim N--5$ & 101 & * 2.547 & $(3.07)$ & 9.142 \\
\hline Pipe 4.2 & $\sim N--5$ & $\sim N--6$ & 101 & *2.547 & $(2.965)$ & 5.118 \\
\hline Pipe 4.3 & $\sim N--6$ & $\sim N--7$ & 101 & $\star 2.547$ & $(2.004)$ & 4.832 \\
\hline Pipe 4.4 & $\sim N--7$ & $\sim N-8$ & 101 & *2.547 & $(8.475)$ & 0.704 \\
\hline Pipe 5 & $\sim N--8$ & $\sim N--9$ & 101 & 6.773 & 0.237 & 1.19 \\
\hline Pipe 6 & $\sim N--9$ & $\sim N-10$ & 101 & 9.663 & $(0.231)$ & 0.189 \\
\hline Pipe 7 & $\begin{array}{l}\sim N-10 \\
\cdots d P: 0.215\end{array}$ & HL: $\quad \stackrel{\sim N-11}{0.444}$ & 101 & 6.773 & $(0.509)$ & 0.574 \\
\hline Pipe 8 & $\sim N-11$ & $\sim N-12$ & 101 & 6.773 & 0.415 & 1.461 \\
\hline Pipe 9 & $\sim N-12$ & $\sim N-13$ & 101 & * 45.08 & 16.6 & 34.55 \\
\hline
\end{tabular}




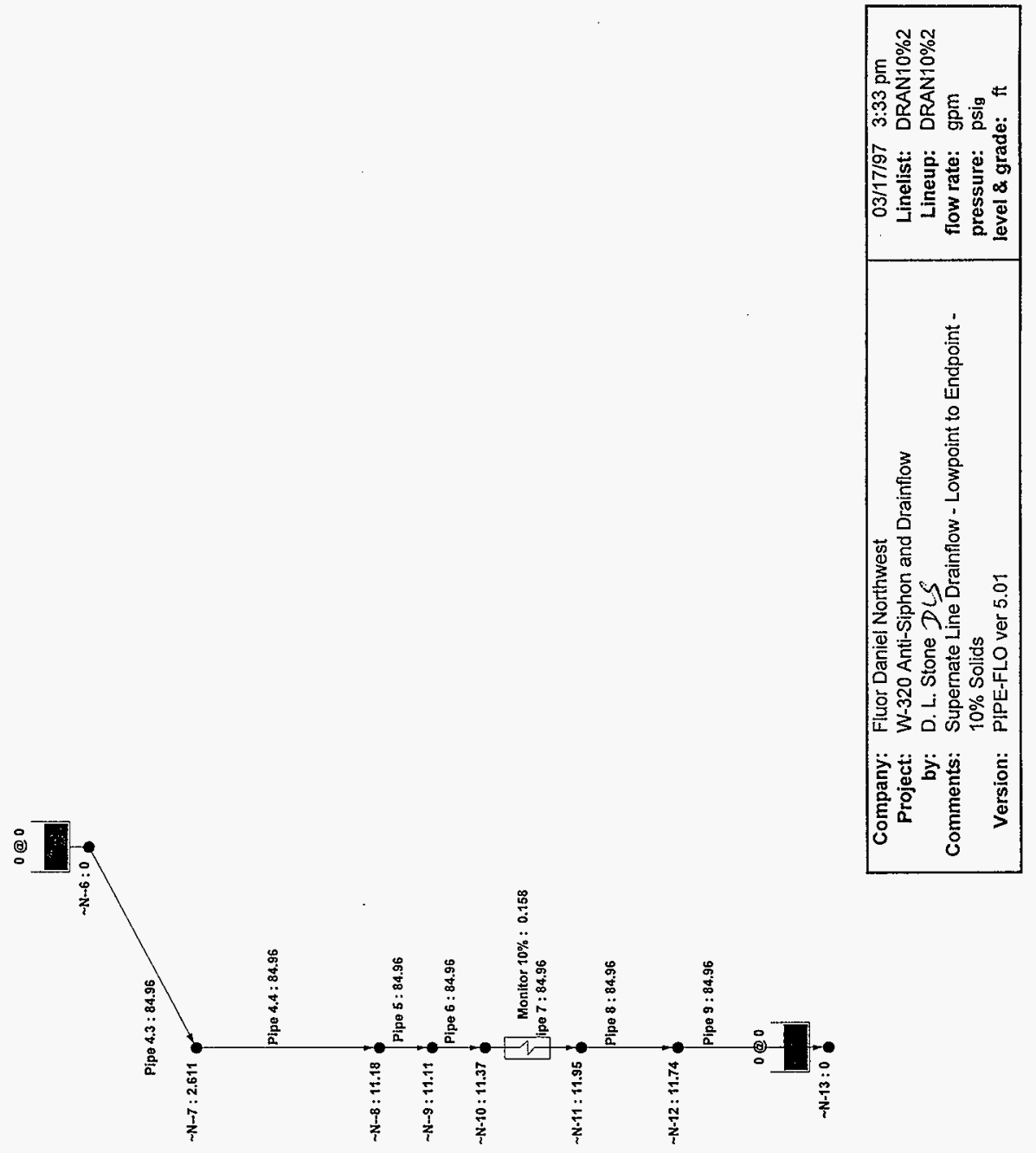


Deviation: $0.0033 \%$ after: 4 iterations

Supernate Line Drainflow - $10 \%$ solids - Source at Stationpoint

Volumetric flow rates require constant fluid properties in all pipelines. Fluid properties in the first specification were used in this calculation.

LINEUP SUMMARIES

\section{PIPELINE}

Pipe 4.3

Pipe 9
FLOW

gpm

« 84.96

$\gg 84.96$
PRESSURE

SOURCE

$\sim \mathrm{N}-\mathrm{-6}$

$\sim N-13$
SET

psi g LEVEL.

0

0

0

0

Flows IN: $84.96 \mathrm{gpm}$

Flows OUT: $84.96 \mathrm{gpm}$

NET FLOWS: $0 \mathrm{gpm}$ 
NODE

$\sim N-6$

$\sim \mathrm{N}-7$

$\sim \mathrm{N}-\mathrm{-8}$

$\sim \mathrm{N}-\mathrm{9}$

$\sim \mathrm{N}-10$

$\sim \mathrm{N}-11$

$\sim \mathrm{N}-12$

$\sim \mathrm{N}-13$

$\begin{array}{ll}\begin{array}{l}\text { ELEVATION } \\ \mathrm{ft}\end{array} & \begin{array}{l}\text { DEMAND } \\ \mathrm{gpm}\end{array} \\ 650.39 & \\ 641.42 & \\ 623.217 & \\ 622.517 & \\ 621.85 & \\ 620.225 & \\ 619.621 & \\ 619.35 & \end{array}$

PRESSURE

psig

0 (source)

2.611

11.18

11.11

11.37

11.95

11.74

0 (source)
H GRADE

$\mathrm{ft}$

650.4

646.8

646.3

645.5

645.3

644.9

643.9

619.3 


\begin{tabular}{|c|c|c|c|c|c|c|}
\hline PIPELINE & FROM & TO & $\begin{array}{l}\text { FLOW } \\
\text { gpm }\end{array}$ & $\begin{array}{l}\text { VEL } \\
\mathrm{ft} / \mathrm{sec}\end{array}$ & $\begin{array}{l}\mathrm{dP} \\
\text { psig }\end{array}$ & $\underset{\mathrm{ft}}{\mathrm{HL}}$ \\
\hline le 4.3 & $\sim N--6$ & $\sim N--7$ & 84.96 & $* 2.143$ & (2.611) & 3.578 \\
\hline Pipe 4.4 & $\sim N-7$ & $\sim N-8$ & 84.96 & $\star 2.143$ & $(8.57)$ & 0.508 \\
\hline Pipe 5 & $\sim N--8$ & $\sim N--9$ & 84.96 & * 5.698 & 0.071 & 0.846 \\
\hline Pipe 6 & $\sim N--9$ & $\sim N-10$ & 84.96 & 8.13 & $(0.256)$ & 0.139 \\
\hline Pipe 7 & $\begin{array}{l}\sim N-10 \\
--d P: 0.158\end{array}$ & $H L: \sim^{\sim N-11}$ & 84.96 & * 5.698 & $(0.582)$ & 0.423 \\
\hline Pipe 8 & $\sim N-11$ & $\sim \mathrm{N}-12$ & 84.96 & * 5.698 & 0.209 & 1.036 \\
\hline Pipe 9 & $\sim \mathrm{N}-12$ & $\sim N-13$ & 84.96 & * 37.93 & 11.74 & 24.51 \\
\hline
\end{tabular}


Appendix M 


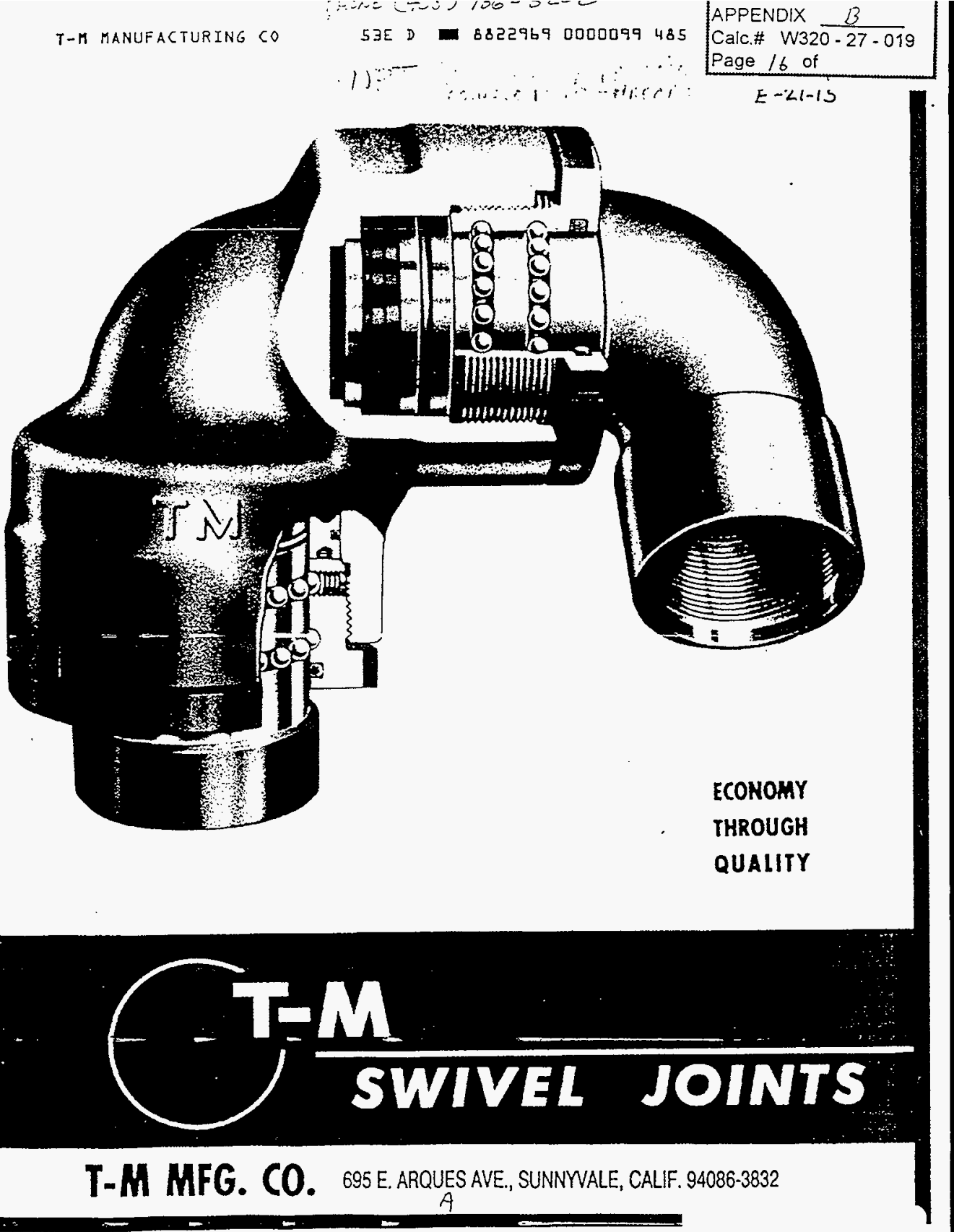

HNF-2477, Rev. 0

Page B-153 


\section{THREADED AND BORED FOR WELDING}

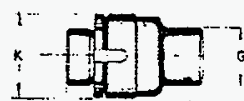

$--P-$

STre 100

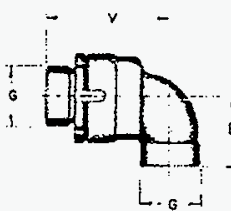

stre 200

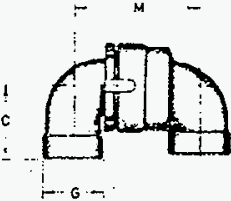

STME 300

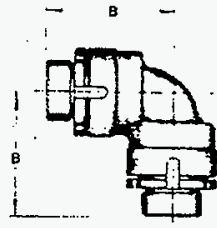

STYLE 400

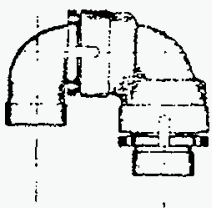

- $0-1$

STRE 500

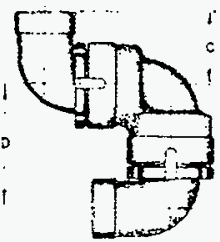

STME 600

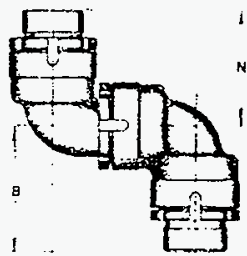

$\rightarrow$ R

STYLE 700

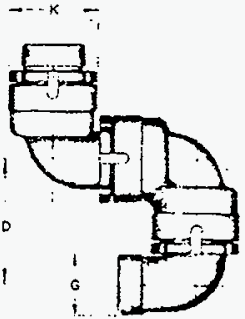

STIE 800

\begin{tabular}{|c|c|c|c|c|c|c|c|c|c|c|c|c|}
\hline & & & D & 1 & $E$ & $N$ & 1 & 0 & $S$ & & & \\
\hline SIZES & B & $c$ & $\mathrm{~B}$ & $E$ & 6 & $K$ & $M$ & $N$ & $P$ & $R$ & $v$ & SIZE \\
\hline $1 / 8 \& 1 / 2$ & $31 / 2$ & 2 & $33 / 8$ & $17 / 8$ & $11 / 4$ & 2 & 3 & $31 / 8$ & $37 / 8$ & $35 / 8$ & $37 / 8$ & $3 / 6 \& 1 / 2$ \\
\hline $3 / 421$ & $41 / 4$ & $23 / 8$ & $41 / 4$ & $21 / 4$ & $13 / 4$ & $27 \%$ & $41 / 8$ & $41 / 8$ & $43 / 6$ & 5 & $4 \frac{1}{8}$ & $3 / 4 \& 1$ \\
\hline $11 / 4$ & $43 / 4$ & $23 / 4$ & $43 / 4$ & $23 / 4$ & $21 / 8$ & $31 / 8$ & $45 \%$ & 458 & $51 / 8$ & $53_{16}$ & $51 / 4$ & $11 / 4$ \\
\hline $11 / 2$ & $51 / 2$ & 3 & 6 & $31 / 4$ & $21 / 2$ & $31 / 2$ & 6 & $51 / 4$ & $53 / 4$ & 5 5/16 & $51 / 8$ & $11 / 2$ \\
\hline 2 & $63 / 8$ & $31 / 2$ & $65 / 8$ & $41 / 4$ & $31 / 8$ & $45 / 8$ & $65 / 8$ & 6 & $63 / 8$ & $7 \%$ & 614 & 2 \\
\hline $21 / 2$ & $67 \%$ & 4 & $73 / 8$ & 4 & $33 / 4$ & $51 / 4$ & $67 / 8$ & $63 / 8$ & $67 / 8$ & $81 / 4$ & $\overrightarrow{63 / 8}$ & $21 / 2$ \\
\hline 3 & $73 / 4$ & $47 / 8$ & $91 / 6$ & $41 / 4$ & $41 / 4$ & $57 / 8$ & $81 / 8$ & 754 & $7 X_{B}$ & $101 / 8$ & 7 & 3 \\
\hline 4 & $91 / 4$ & $51 / 2$ & $10^{1 / 8}$ & $51 / 2$ & $51 / 2$ & $7^{1 / 4}$ & $102 / 8$ & $91 / 4$ & $83 / 4$ & $111 / 2$ & $85 / 8$ & 4 \\
\hline
\end{tabular}

All dimensions given in inchas $\pm 1 / 8^{*}$

For sizes larger than $4^{\prime \prime}$ efer to

section on fabricated joints. 
INSTALLATION, OPERATION, AND MAINTENANCE MANUAL

\section{TITLE} $\therefore . .2$

CUSTOMER: WESTINGHOUSE HANFORD COMPANY

USER: WESTINGHOUSE HANFORD COMPANY

SERVICE: TRANSFER AND SLUICE PUMPS

LOCATION: . RICHLAND, WA

PURCHASE ORDER NO: WHC P.O. W-78259-Z4

PUMP SERIAL NO:

$91231-1,91231-2,91232-1 \& 91232-2$

PUMP ITEM NO:

P-1361, P-0621, P-1361 \& P-0621 


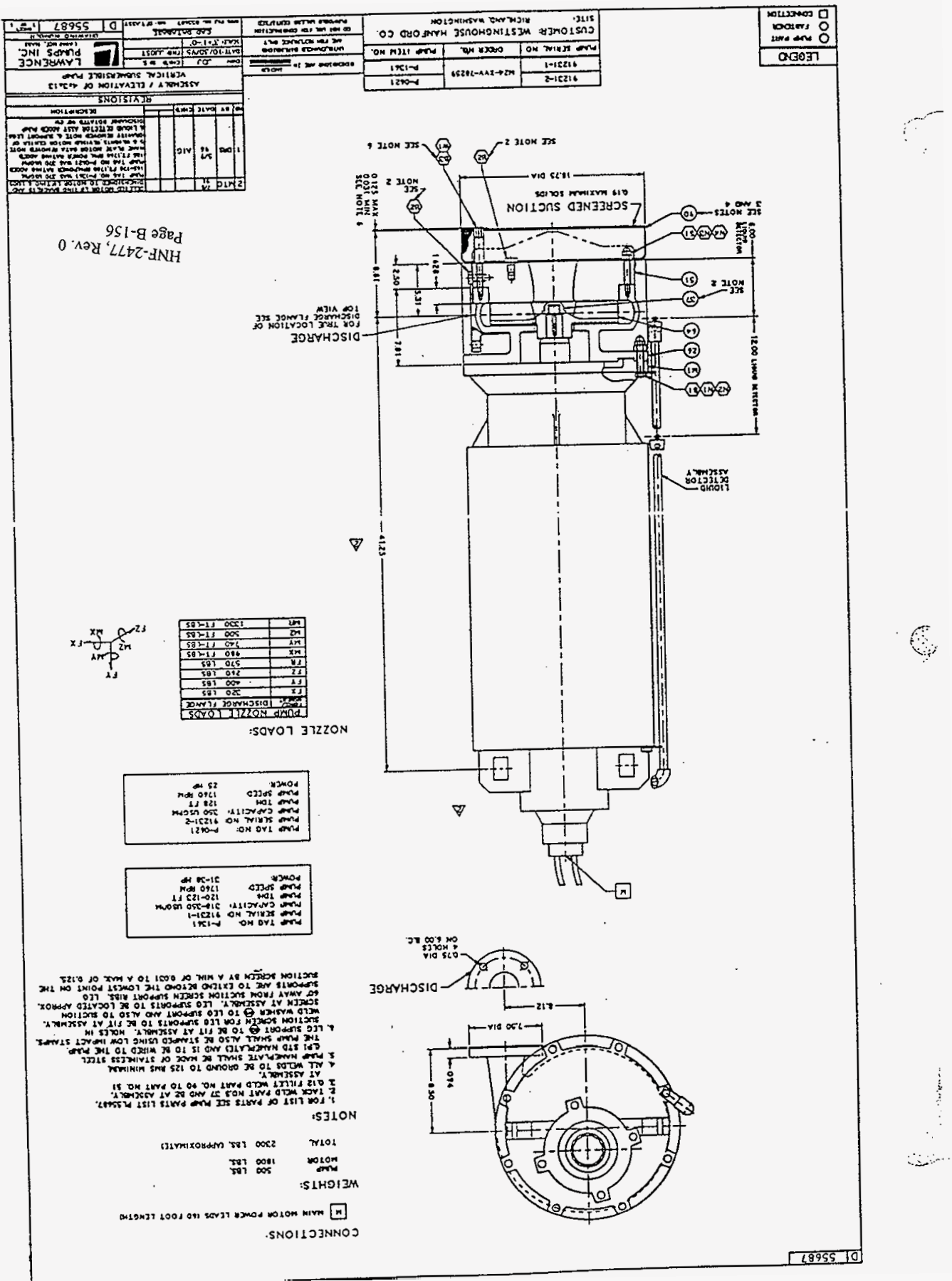



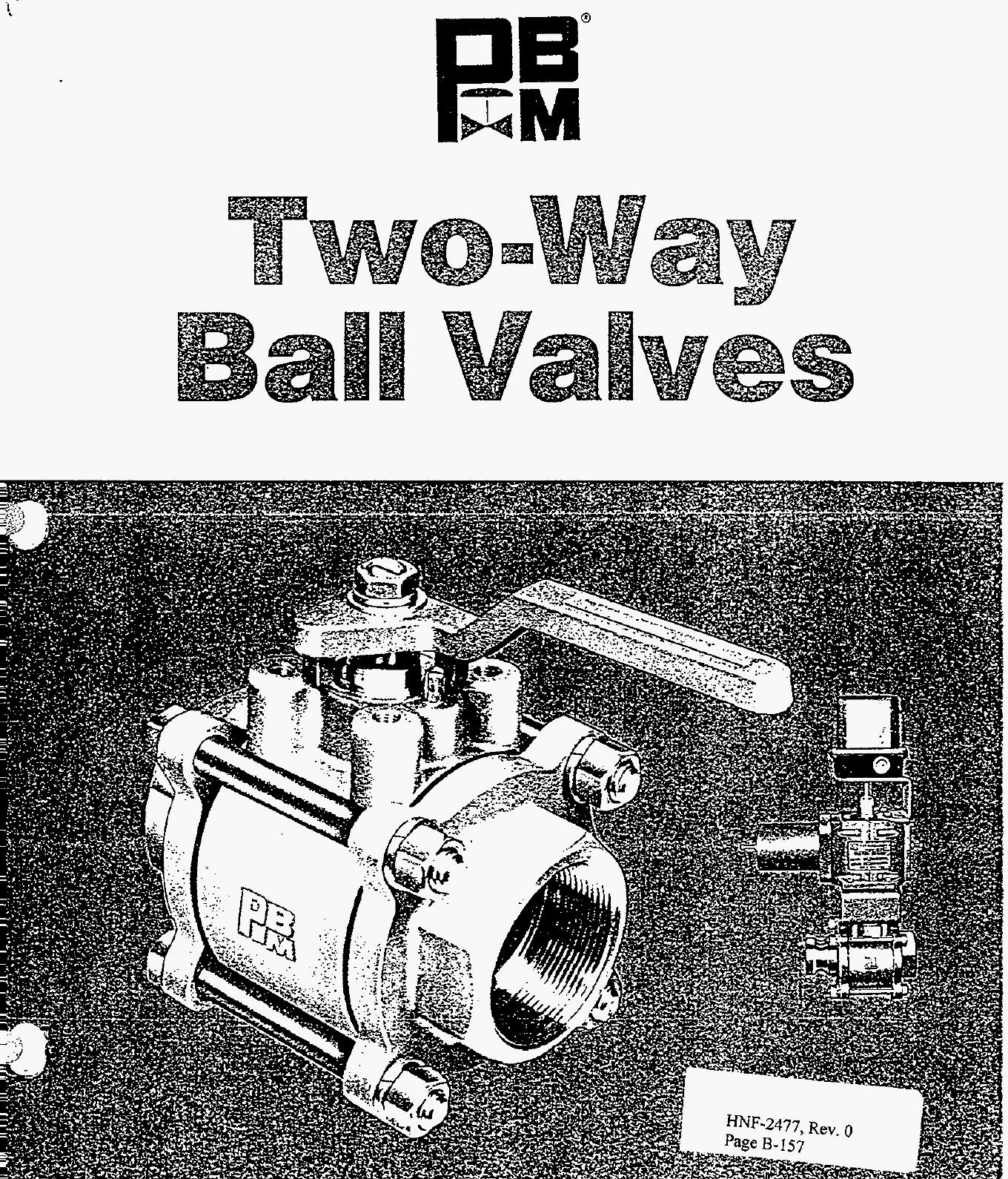
Engineering Data

Dimensions for SP SERIES

Female NPT • Socket Weld $1 / 4$ " thru 4 "

Butt Weld

$1 / 2^{\prime \prime}$ thru $4^{\prime \prime}$

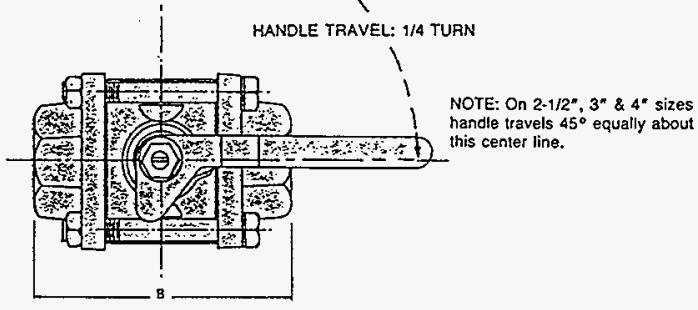

$1 / 4^{*}, 3 / 8^{*}, 1 / 2^{*}, 3 / 4^{\prime \prime} \& 1$ * valves have 3 bolts $1.1 / 4^{*}, 1-1 / 2^{\prime \prime}, 2^{*} \& 2 \cdot 1 / 2^{n}$ valves have 4 bolts

$3^{\mathrm{m}}$ valves have 6 bolts

$4^{\prime \prime}$ valves have 8 bolls

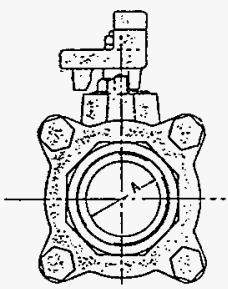

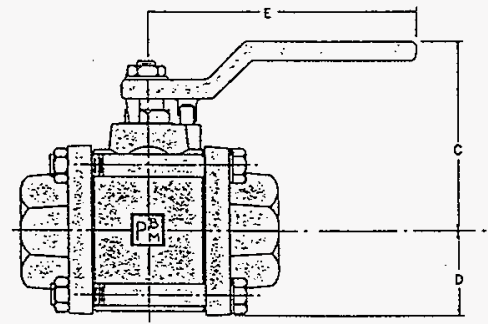

FEMALE NPT

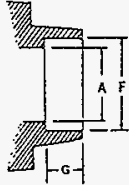

SOCKET WELD

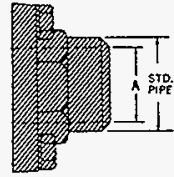

BUTT WELD

\begin{tabular}{|c|c|c|c|c|c|c|c|c|c|c|c|c|}
\hline \multirow{2}{*}{$\begin{array}{l}\text { PIPE } \\
\text { SIZE } \\
\text { (lnch) }\end{array}$} & \multicolumn{5}{|c|}{ FEMALE NPT } & \multicolumn{2}{|c|}{ SOCKET WELD } & \multicolumn{5}{|c|}{ APPROX. WT. (LBS.) } \\
\hline & Port Dia. & $\begin{array}{c}\text { B } \\
\text { Length }\end{array}$ & $\begin{array}{c}\mathrm{C} \\
\text { Height }\end{array}$ & $\mathbf{D}$ & $\begin{array}{c}E \\
\text { Handles }\end{array}$ & $\begin{array}{c}\text { F } \\
\text { Dia. }\end{array}$ & G. & Bronze & Iron & $\mathrm{S} / \mathrm{S}$ & $A L$ & $\mathrm{c} / \mathrm{s}$ \\
\hline $1 / 4^{n}$ & $.62^{N}$ & $3.12^{\prime \prime}$ & $2.16^{n}$ & $1.34^{* \prime}$ & $3.69^{\prime \prime}$ & $.56^{n}$ & $.81^{\circ}$ & 2 & $11 / 2$ & $93 / 4$ & $3 / 4$ & $13 / 4$ \\
\hline $3 / 8^{\prime \prime}$ & $.62^{\prime \prime}$ & $3.12^{\prime \prime}$ & $2.16^{*}$ & $1.34^{\prime \prime}$ & $3.69^{n}$ & $.69^{\prime \prime}$ & $.81^{\circ}$ & 2 & $11 / 2$ & $13 / 4$ & $3 / 4$ & $13 / 4$ \\
\hline $1 / 2^{\prime \prime}$ & $.62^{\prime \prime}$ & $3.12^{\prime \prime}$ & $2.16^{\prime \prime}$ & $1.34^{\prime \prime}$ & $3.69^{\prime \prime}$ & $.86^{\prime \prime}$ & $.81^{\prime \prime}$ & 2 & $11 / 2$ & $13 / 4$ & $3 / 4$ & $13 / 4$ \\
\hline $3 / 4^{\pi}$ & $.81^{\prime \prime}$ & $3.44^{n}$ & $2.28^{\prime \prime}$ & $1.47^{n}$ & $3.69^{n}$ & $1.06^{\prime \prime}$ & $.81^{\circ}$ & $21 / 4$ & $13 / 4$ & $21 / 4$ & $3 / 4$ & $21 / 4$ \\
\hline $1 "$ & $1.00^{n}$ & $3.88^{\prime \prime}$ & $2.86^{n}$ & $1.69^{\prime \prime}$ & $4.31^{\prime \prime}$ & $1.34^{\prime \prime}$ & $.94^{\prime \prime}$ & $33 / 4$ & 3 & $31 / 2$ & $19 / 4$ & $31 / 2$ \\
\hline $11 / 4^{*}$ & $1.25^{\prime \prime}$ & $4.54^{*}$ & $3.78^{\circ}$ & $1.56^{\prime \prime}$ & $5.50^{\prime \prime}$ & $1.69^{m}$ & $1.12^{\prime \prime}$ & $71 / 2$ & $61 / 4$ & $7 \% / 4$ & $21 / 2$ & $71 / 4$ \\
\hline $11 / 2^{4}$ & $1.50^{\prime \prime}$ & $5.38^{\prime \prime}$ & $4.03^{\prime \prime}$ & $1.70^{\prime \prime}$ & $5.50^{n}$ & $1.92^{N}$ & $1.16^{\prime \prime}$ & $91 / 2$ & 8 & 9 & 3 & 9 \\
\hline $2^{\prime \prime}$ & $1.94^{\prime \prime}$ & $5.75^{\prime \prime}$ & $4.38^{\prime \prime}$ & $2.03^{\prime \prime}$ & $5.50^{\prime \prime}$ & $2.41^{\prime \prime}$ & $1.12^{\prime \prime}$ & $123 / 4$ & $11 \frac{1}{2}$ & $121 / 2$ & 4 & $12^{1 / 2}$ \\
\hline $21 / 2^{n}$ & $2.50^{n}$ & $8.31^{\prime \prime}$ & $5.31^{\prime \prime}$ & $2.77^{\prime \prime}$ & $12.00^{\prime \prime}$ & $2.94^{\prime \prime}$ & $1.56^{\prime \prime}$ & $311 / 2$ & $281 / 2$ & & 10 & \\
\hline $3^{\prime \prime}$ & $2.75^{\prime \prime}$ & $8.62^{\prime \prime}$ & $6.69^{n}$ & $3.88^{\prime \prime}$ & $12.00^{\prime \prime}$ & $3.55^{\prime \prime}$ & $1.88^{\circ}$ & 50 & 45 & 48 & 16 & 48 \\
\hline $4^{\prime \prime}$ & $3.50^{\prime \prime}$ & $10.50^{\prime \prime}$ & $7.14^{\prime \prime}$ & $4.47^{\prime \prime}$ & $12.00^{\prime \prime}$ & $4.55^{\prime \prime}$ & $2.12^{\prime \prime}$ & 82 & 75 & 72 & 26 & 72 \\
\hline
\end{tabular}

(NOTE: Male NPT, Solder-Joim, T-Klamp, Cherry Burrell, Sil-Braze, and Grooved Ends are available in certain sizes and metals. Call or write us for data.)

\begin{tabular}{|c|c|c|c|c|c|c|c|c|c|}
\hline \multirow{2}{*}{$\begin{array}{l}\text { PIPE } \\
\text { SIZE } \\
\text { (Inch) }\end{array}$} & \multicolumn{5}{|c|}{ BUTT WELD } & \multicolumn{4}{|c|}{ APPROX. WT. (LBS.) } \\
\hline & Port Dia. & $\begin{array}{c}\text { B } \\
\text { Length }\end{array}$ & $\begin{array}{c}\text { C } \\
\text { Height }\end{array}$ & D & $\begin{array}{c}E \\
\text { Handle }\end{array}$ & Iron & $5 / S$ & $A L$ & $\mathrm{C} / \mathrm{s}$ \\
\hline $1 / 2^{n}$ & $.62^{*}$ & $3.12^{n}$ & $2.16^{\prime \prime}$ & $1.34^{*}$ & $3.69^{\prime \prime}$ & $13 / 6$ & 2 & $3 / 4$ & 2 \\
\hline $3 / 4^{\prime \prime}$ & $.81^{\prime \prime}$ & $3.44^{m}$ & $2.28^{\prime \prime}$ & $1.47^{\prime \prime}$ & $3.69^{n}$ & 2 & $21 / 2$ & 1 & $21 / 2$ \\
\hline $1^{\prime \prime}$ & $1.00^{n}$ & $3.88^{\prime \prime}$ & $2.86^{n}$ & $1.69^{\prime \prime}$ & $4.31^{\prime \prime}$ & $31 / 4$ & $33 / 4$ & $11 / 2$ & $33 / 4$ \\
\hline $1 \frac{1 / 2 "}{}$ & $1.50^{\prime \prime}$ & $5.38^{\prime \prime}$ & $4.03^{n}$ & $1.70^{\prime \prime}$ & $5.50^{n}$ & $81 / 2$ & $9^{1 / 2}$ & $31 / 4$ & $91 / 2$ \\
\hline $2^{\prime \prime}$ & $1.94^{\prime \prime}$ & $5.75^{\mu}$ & $4.38^{\prime \prime}$ & $2.03^{\prime \prime}$ & $5.50^{\prime \prime}$ & 12 & 13 & $41 / 4$ & 13 \\
\hline $3^{n}$ & $2.75^{\prime \prime}$ & $8.62^{\prime \prime}$ & $6.69^{\prime \prime}$ & $3.88^{n}$ & $12.00^{\prime \prime}$ & $451 / 2$ & $481 / 2$ & 16 & $481 / 2$ \\
\hline $4^{\prime \prime}$ & $3.50^{\circ}$ & $10.50^{n}$ & $7.14^{\prime \prime}$ & $4.47^{\prime \prime}$ & $12.00^{n}$ & 76 & 73 & $261 / 2$ & 73 \\
\hline
\end{tabular}

HNF-2477, Rev. 0 Page B-158

Sch 40 dimensions shown. Sch 10 and Sch 5 Butt Weld Ends also available. 
316 STAINLES STEE (AUstentile Grade)

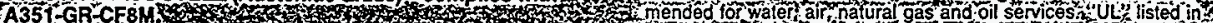

This metal is exceptionally con rosive-resistant to such reducing solut

tions as sulphuric and fatty acids: Since if does not pit readjly it

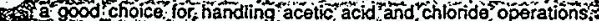

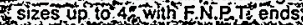

inclúding sea water

4. CARBON STEEL - complies With A216-WCB/

Ain ASTM SPEC No B-62 (CDA Alloy $\mathrm{NO}_{836}$ )

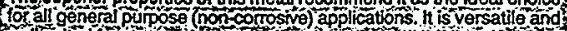

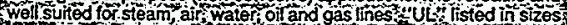

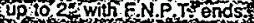
This is a highty versatile materal with extreme strength' making E very useful when valyes require unusual osistance to shock vibra

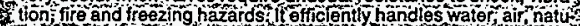
ral gas and ol and otien noncontrosive media

ALU HINUM this material, noted equaliy for to strongth and lightness, bocomes an deal choice for handing such modia as nitricic chromic; and most TRON complies With ASTM Grade 32510

This highi pop a materal provides amost the same high stength of steel but it is priced somewhat lowertífeatures extreme tesis of the or an acids

\section{$C_{V}$ factors for 'SP' series Ball Valves}

$C_{V}$ is defined as the number of U.S. gallons of water per minute, at standard conditions ( $60 \mathrm{~F}^{\circ}$ (1) 14.7 PS(A) that will flow through a valve at a 1 PSIG Pressure drop across the Valve.
The Sizing Formulas
2 For valve sizes in each of thesemetals please see

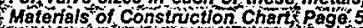

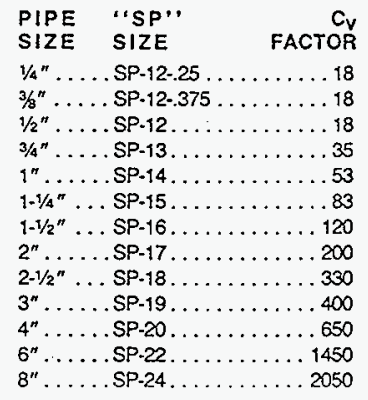

$C_{y}$

\section{R} .35

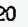
200 330 400
(1). LQUID;

$$
\begin{aligned}
& C_{v}=G P M \sqrt{\frac{G}{P}} \\
& G P M=C_{v} \sqrt{\frac{. P}{G}}
\end{aligned}
$$$$
{ }_{s} P=\left[\frac{G P M}{C_{V}}\right]^{2}(G)
$$

\section{(2). SATURATED STEAM}

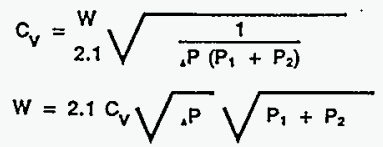

$P=\left[\frac{\bar{v}}{.0159 w}\right]^{2}$

\section{Nomenclature}

$$
\begin{aligned}
& \text { GPM - U.S. Gallons per Minute } \\
& W \text { - Pound per hour } \\
& \text { Q - Cubic feet per hour } Q 60^{\circ} \mathrm{F} \\
& \text { and } 14.7 \text { PSIA } \\
& \text { G - Specific Gravity } \\
& \vec{V} \text { - Specific volume of inlet steam } \\
& \text { of - inlet gas temperature } \\
& P_{1} \text { - inlet pressure in PSIA } \\
& \mathrm{P}_{2} \rightarrow \text { Ovtlet pressure in PSIA } \\
& \text { iP - Pressure drop across the valve } \\
& \text { in PSI. Must not be greater }
\end{aligned}
$$

- Pounds per hour may be converted to standard cubic feet per hour by the following formula.

$$
Q=\frac{W}{0.0764 G}
$$



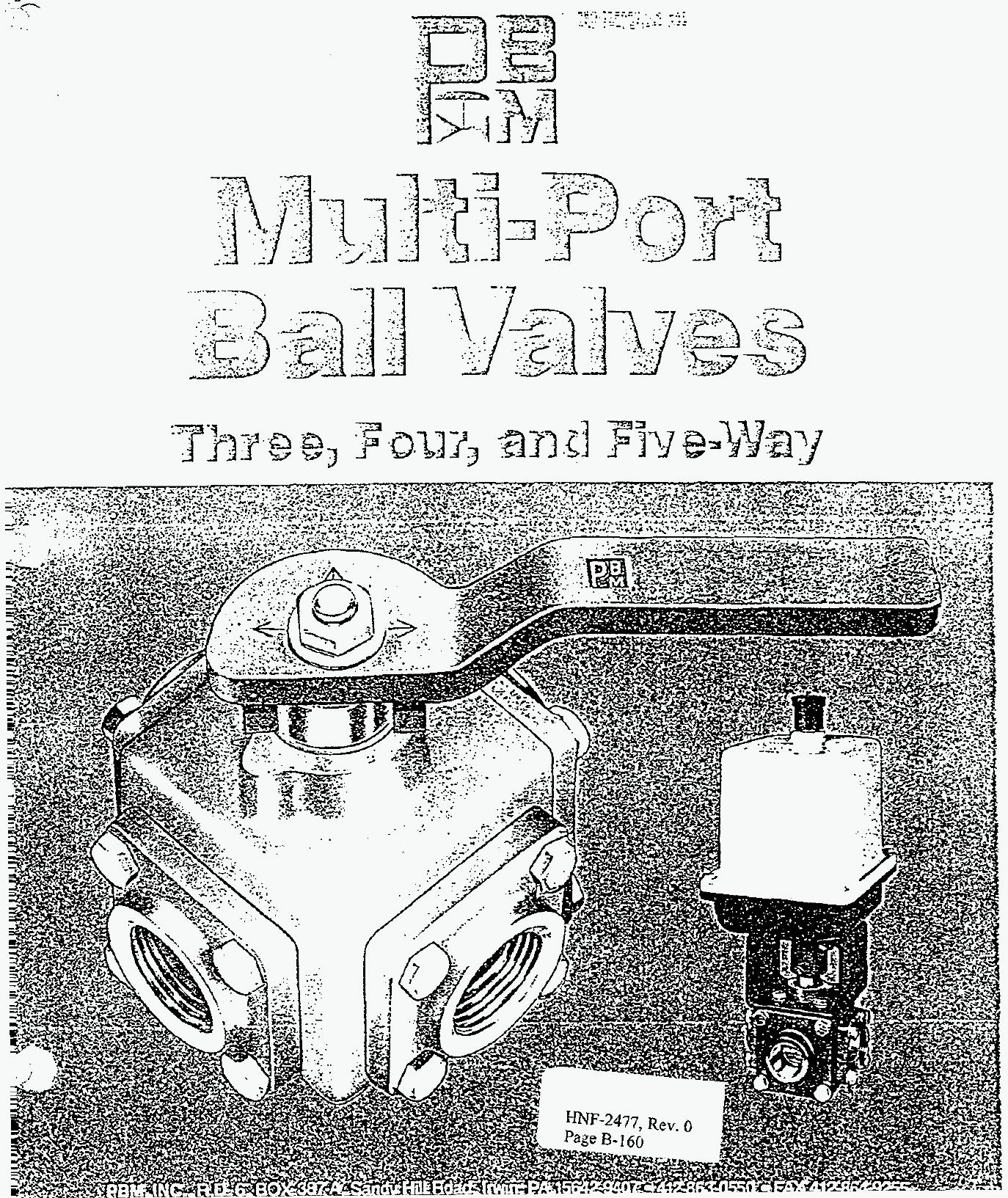
3 \& 4-way BT
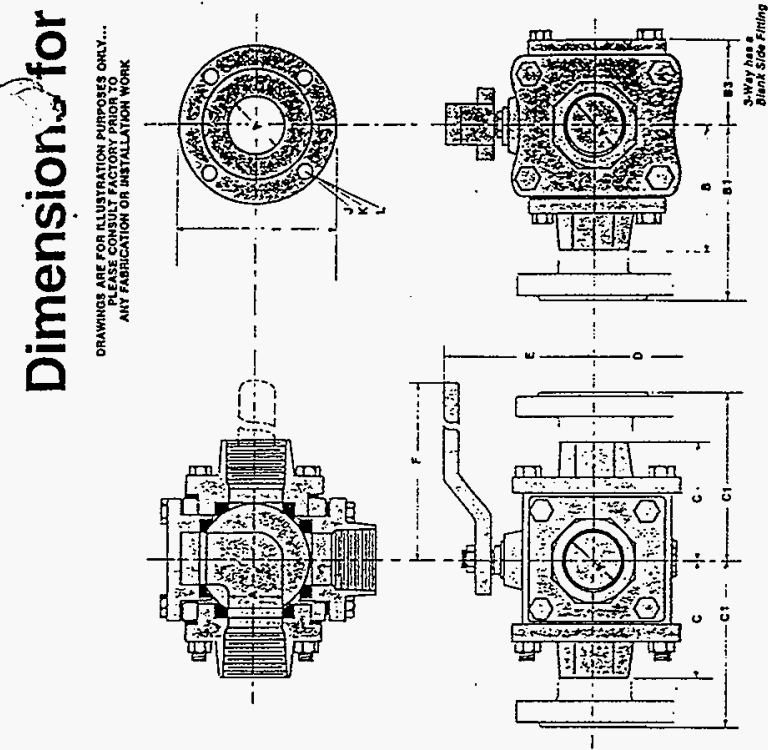

HNF-2477, Rev. 0

Page B-161
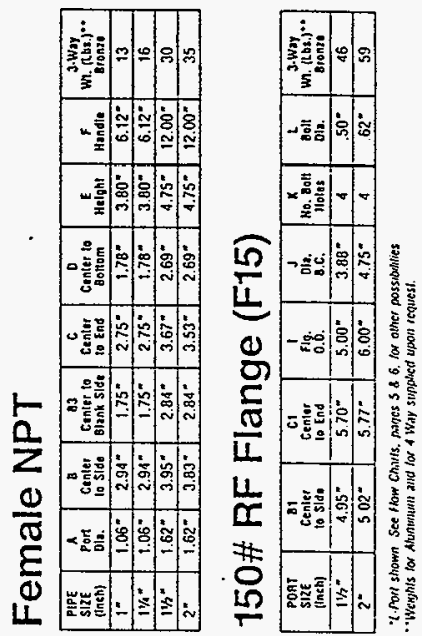

$C_{V}$ Factors for MP and BT Series Ball Valves

$\mathrm{C}_{\mathrm{y}}$ is defined as the number of U.S. gallons of water per minute, at standard conditions $\left(60^{\circ} \mathrm{F} @ 14.7 \mathrm{PSIA}\right)$ that will flow through a valve at a 1 PSIG pressure drop across the Valve.

\begin{tabular}{|c|c|c|c|c|}
\hline $\begin{array}{l}\text { Pipe } \\
\text { Size }\end{array}$ & $\begin{array}{l}\text { PBM } \\
\text { Code }\end{array}$ & $\begin{array}{c}\text { Straight Thet } \\
C_{y}\end{array}$ & $\begin{array}{c}\text { Side } \\
C_{V}\end{array}$ & $\begin{array}{c}L_{\text {P Port }} \\
\mathrm{C}_{\mathrm{V}}\end{array}$ \\
\hline $1 / 2 "$ & 12 & 16 & 10 & 8 \\
\hline $3 / 4^{n}$ & 13 & 16 & 10 & 8 \\
\hline $1^{\prime \prime}$ & 14 & 45 & 25 & 22 \\
\hline $114^{n}$ & 15 & 45 & 25 & 22 \\
\hline $11 / 2^{n}$ & 16 & 100 & 56 & 46 \\
\hline $2^{\prime \prime}$ & 17 & 180 & 100 & 78 \\
\hline $3^{n}$ & 19 & 228 & 127 & 90 \\
\hline $4^{\prime \prime}$ & 20 & 405 & 225 & 175 \\
\hline
\end{tabular}

The Sizing Formulas

(1). LQuid:

(2). SATURATED STEAM

(3). GAS:

$c_{v}=G P M \sqrt{\frac{G}{P}}$

$C_{v}=W_{2.1}^{W} \sqrt{\frac{1}{P\left(P_{.1}+P_{2}\right)}}$

$c_{v}={ }_{1360}^{Q} \sqrt{\frac{G\left(460+{ }^{P} F\right)}{{ }^{P}}} \sqrt{\frac{2}{P_{1}+P_{2}}}$

$G P M=C_{V} \sqrt{\frac{A P}{G}}$

$W=2.1 C_{V} \sqrt{. P} \sqrt{P_{1}+P_{2}}$

$Q=(1360) C_{v} \sqrt{\frac{P}{G\left(460+{ }^{\circ} F\right)}} \sqrt{\frac{P_{1}+P_{2}}{2}}$

${ }_{A} P=\left[\frac{G P M}{C_{V}}\right]^{2}(G)$
$P=\left[\frac{\bar{v}}{\left.\frac{C_{v}}{.0159 W}\right]^{2}}\right.$
Nomenclature

$$
\begin{aligned}
& \text { GPM - U.S. Galions per Minute } \\
& \text { W - Pound per hour. } \\
& \text { Q - Cubic feet per hour (1) } 60^{\circ} \mathrm{F} \\
& \text { and 14.7 PSLA } \\
& \text { G - Specific Gravity } \\
& \bar{V} \quad \text { - Specific volume of injet steam } \\
& { }^{\circ} \mathrm{F} \text { - Inlet gas temperature } \\
& P_{1} \quad \text { - Iniet pressure in PSIA } \\
& P_{2} \text { - Outlet pressure in PSLA } \\
& \text {.P - Pressure drop across the valve }
\end{aligned}
$$

- Pounds per hour may be converted to standard cubic leet per hour by the following formula.

$$
Q=\frac{W}{0.0764 G}
$$




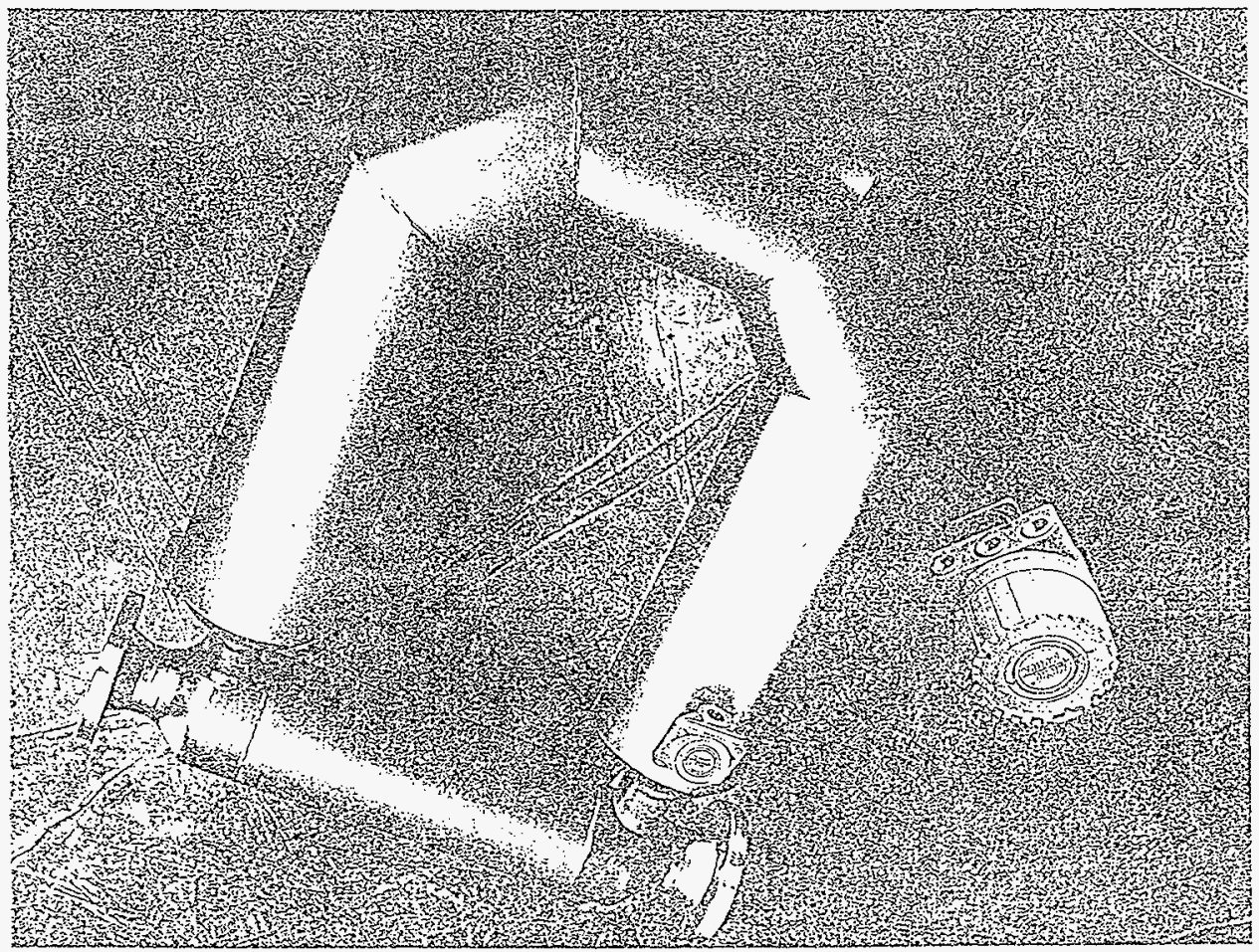

(

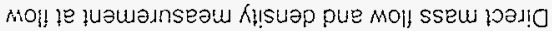

\section{losues Rilsueg pue $\mathrm{MO} \exists \mathrm{SSEN}$ OOE $\exists$ NO IOPON}




\section{Model CMF300}

Micro Motion's ELITE Model CMF300 sensor offers the most accurate mass flow and density measurement for a variety of fluid processes, while exhibiting exceptionally low pressure drop. The flow tubes can accommodate up to 1450 psig (100 bar) and the compact housing safely contains pressure up to $150 \mathrm{psig}$ (10 bar).

The Model CMF300, working with the microprocessor-based ELITE Model RFT8739 transmitter, directly measures the mass flow and density of process fluids at flow rates from 0 to $10,000 \mathrm{lb} / \mathrm{min}(0$ to $272,100 \mathrm{~kg} / \mathrm{hr})$ and temperatures from .400 to $400^{\circ} \mathrm{F}\left(-240\right.$ to $\left.204^{\circ} \mathrm{C}\right)$. The sensor and explosion-proof transmitter can be installed in the same hazardous area.

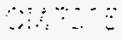

$\therefore \therefore$

Con

Co:

The Model CMF300 is available in a wide selection of standard fluid connections for virtually any fluid process.

CMF300

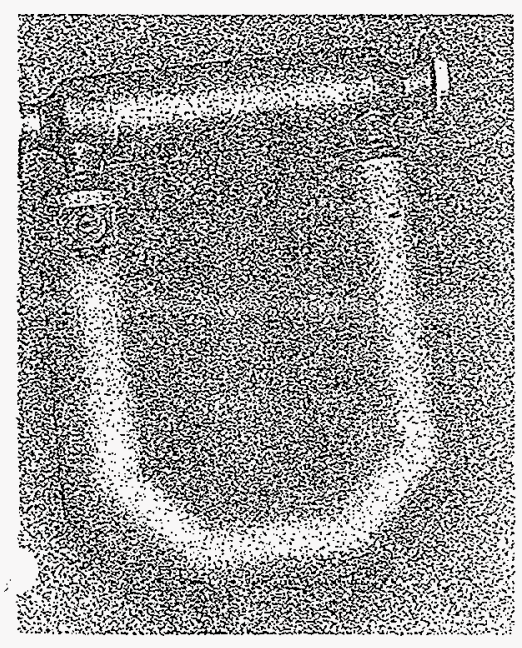




\section{CMF300 physical specifications}

Dimensions in inches
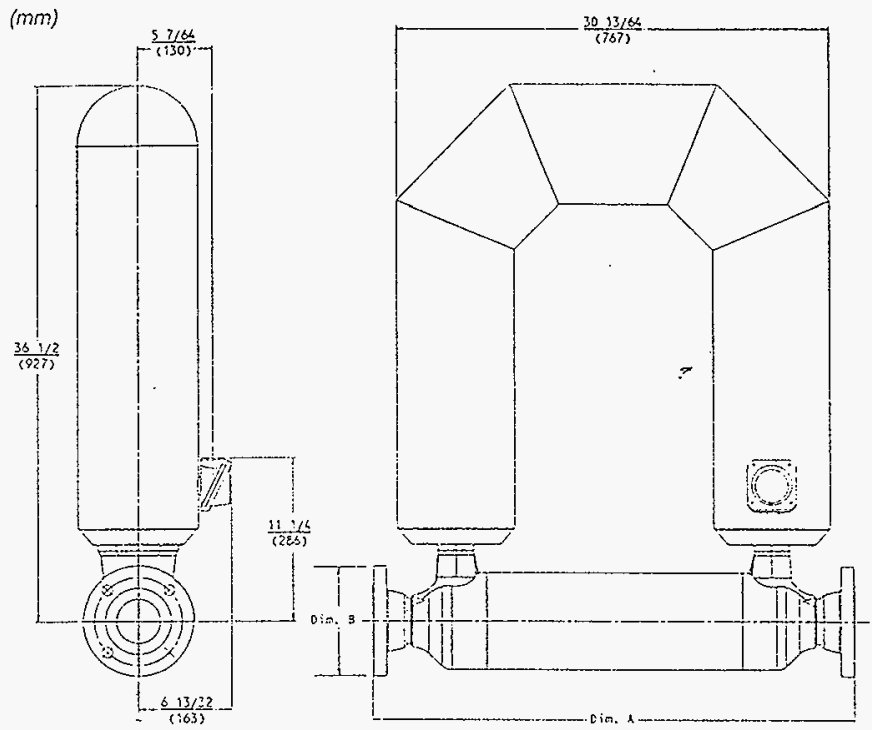

Fittings table

Description of 316L stainless steel fittings

Dim. A

Dim. B

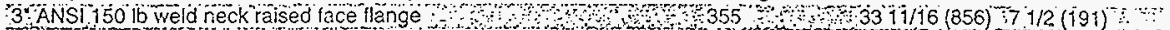
3" ANS1 $300 \mathrm{lb}$ weld neck raised face riange
356
$347 / 16(875) \quad 81 / 4(210)$

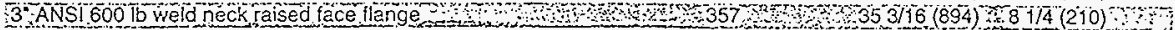

4" ANSI $150 \mathrm{lb}$ weld neck raised face flange

425

$341 / 16(865) 9(229)$

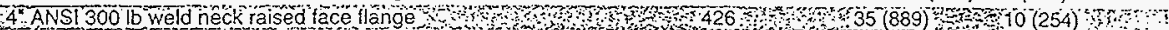

4" ANSI 600 bb weld neck raised face flange $\quad 427 \quad 3611 / 16(932)$ 10 3/4 (273)

3 sanitar fitting

$80 \mathrm{~mm}$ DIN PN40 weld neck. DIN 2526, fype C facing $391 \quad 327 / 8$ (835) $77 / 8$ (200)

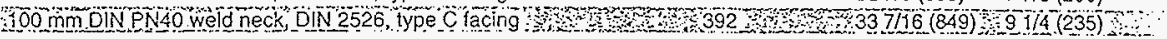

$80 \mathrm{~mm}$ DIN PN40 weld neck, DIN 2512, type N grooved facing $393 \quad 327 / 8(835) \quad 77 / 8(200)$

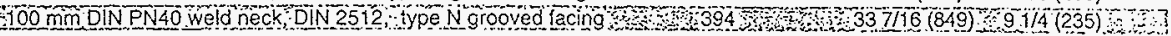

$80 \mathrm{~mm}$ DIN PN 100 weld reck, DIN 2526, type C facing $395 \quad 349 / 16(878) \quad 91 / 16(230)$

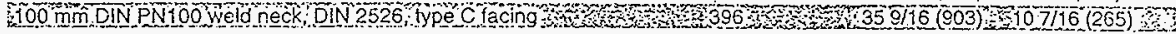

$80 \mathrm{~mm}$ DIN PN100 weld neck, DIN 2512, type N grooved facing $397 \quad 349 / 16$ (878) $91 / 16$ (230)

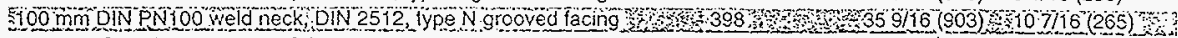

$80 \mathrm{~mm}$ JiS $10 \mathrm{~K}$ welo neck, JiS facing $\frac{400}{333 / 8(848)} 75 / 16(186)$

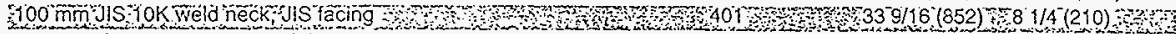

$80 \mathrm{~mm}$ JIS $20 \mathrm{~K}$ weld neck, JIS lacing $402 \quad 333 / 8(848) \quad 77 / 8(200)$

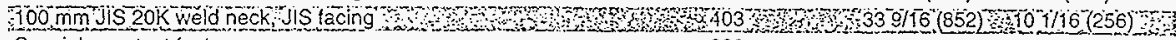

Special - contact factory

939

Description of Hastelloye C-22 fittings

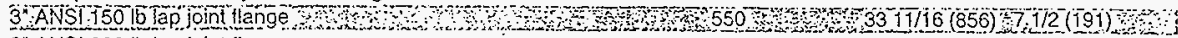
3" ANSI 300 lo lap joint flange

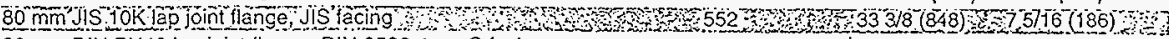

$80 \mathrm{~mm}$ DIN PN40 lap joint flange, DIN 2526 , lype $\mathrm{C}$ facing

553

$327 / 8(835) \quad 77 / 8(200)$ 


\section{.ow Rate vs. Pressure Drop}

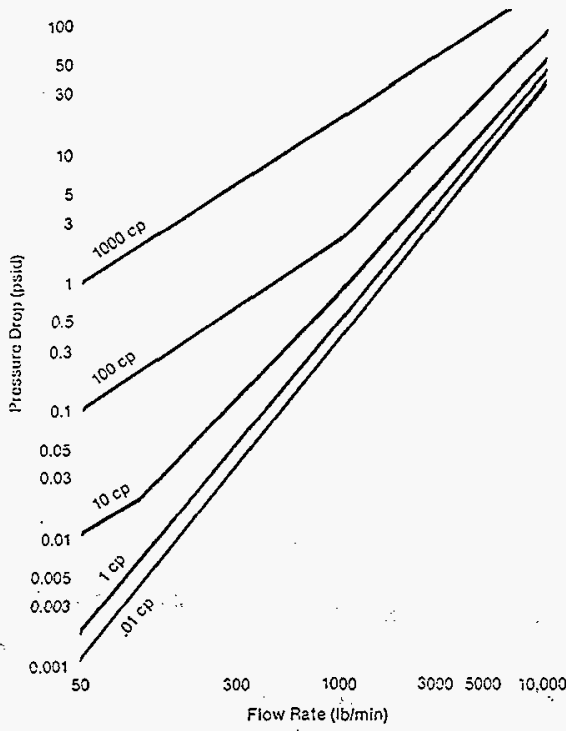

Finding pressure drop of process fluid's with a viscosity near 1 centipoise ( $1 \mathrm{cp}$ )

1. The pressure drop charts shown above have several curves, which represent different viscosity (cp) values. For fluids with a viscosity similar to water, use the curve labeled $1 \mathrm{cp}$.

2. Locate the point on the English Units or Metric Units graph where the vertical line representing the desired tlow rate intersects the curve labeled $1 \mathrm{cp}$.

3. From that point, locate the nearest horizontal line, then $r \in f e r$ to the left side of the graph, which indicates pressure drop (in psi or bar) at the desired ilow rate.

4. Divice the pressure drop indicated on the graph by the specific gravity (S) of the process fluid relative to water:

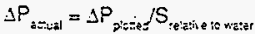

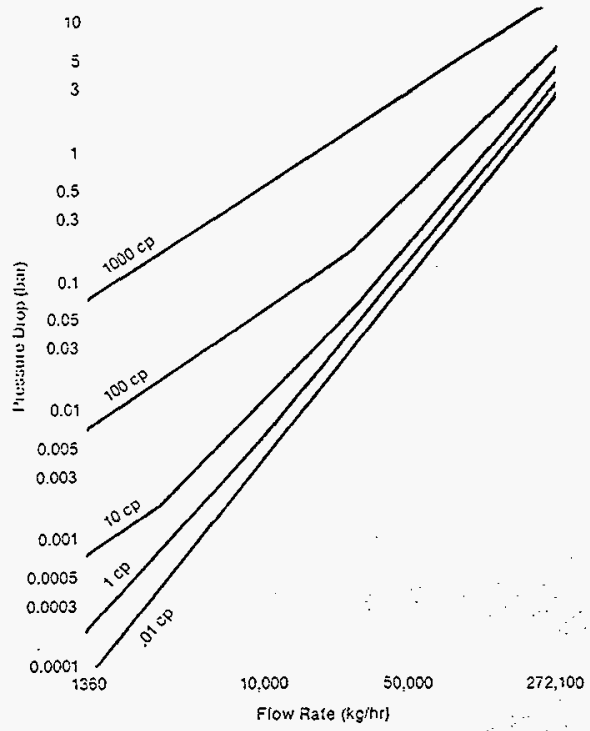

Finding pressure drop of process fluids with a viscosity above 1 centipoise (1 $\mathrm{cp}$ )

1.The pressure drop charts shown above have several curves, which repiesent different viscosity ( $c p$ ) velues. Use method $a$ or $b$, below, to find the process fluid viscosity $\left(t_{\text {visessiry }}\right)$.

a. For fluids with a viscosity between any two values plotted on the English Units or Metric Units graph, interpolate the approximate $f_{\text {viscssing }}$ location.

b. For fluids with a viscosity above the highest value plotted on the graph, find the ratio of actual viscosity to plotted viscosity:

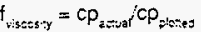

2. Mutitioly the pressure drop incicated on the left side of the graph by the $f_{\text {vistes:y }}$ value from step 1:

$\Delta P=\Delta P_{\text {:ikited }} \times f_{\text {risis:s:r }}$

3.To find the actual pressure drop, divide the $\triangle P$ from step 2 by the specific gravity (S) of the process fluid reletive to water:

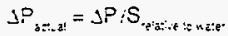




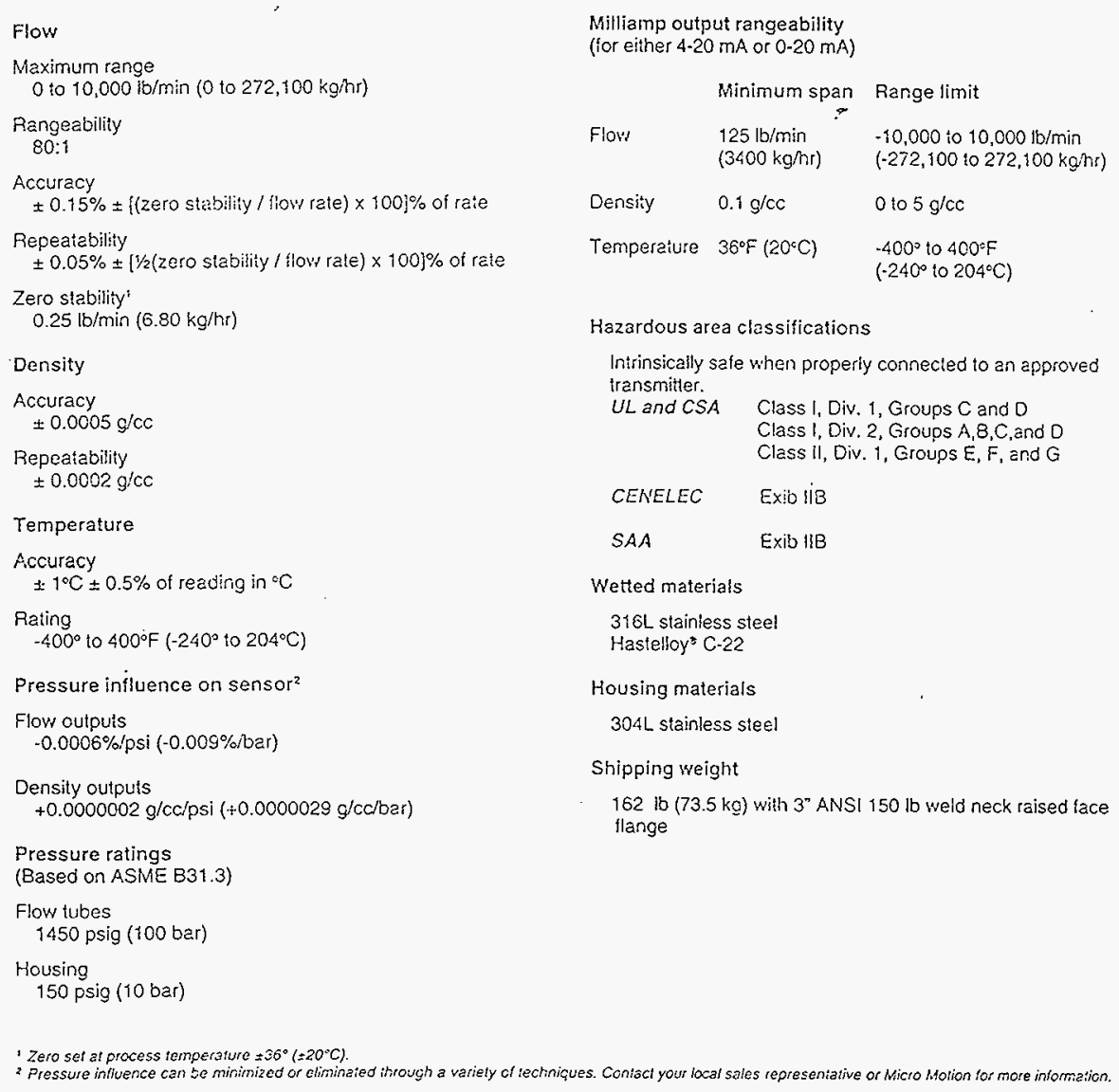


Appendix N 


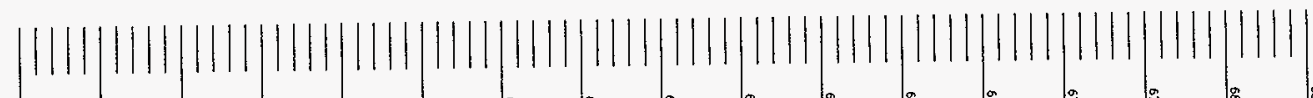

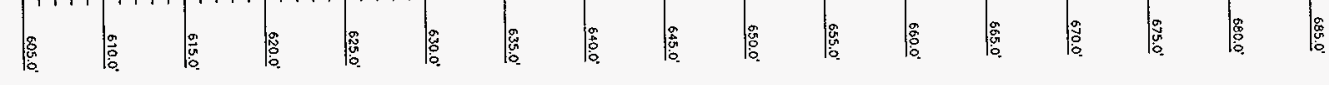
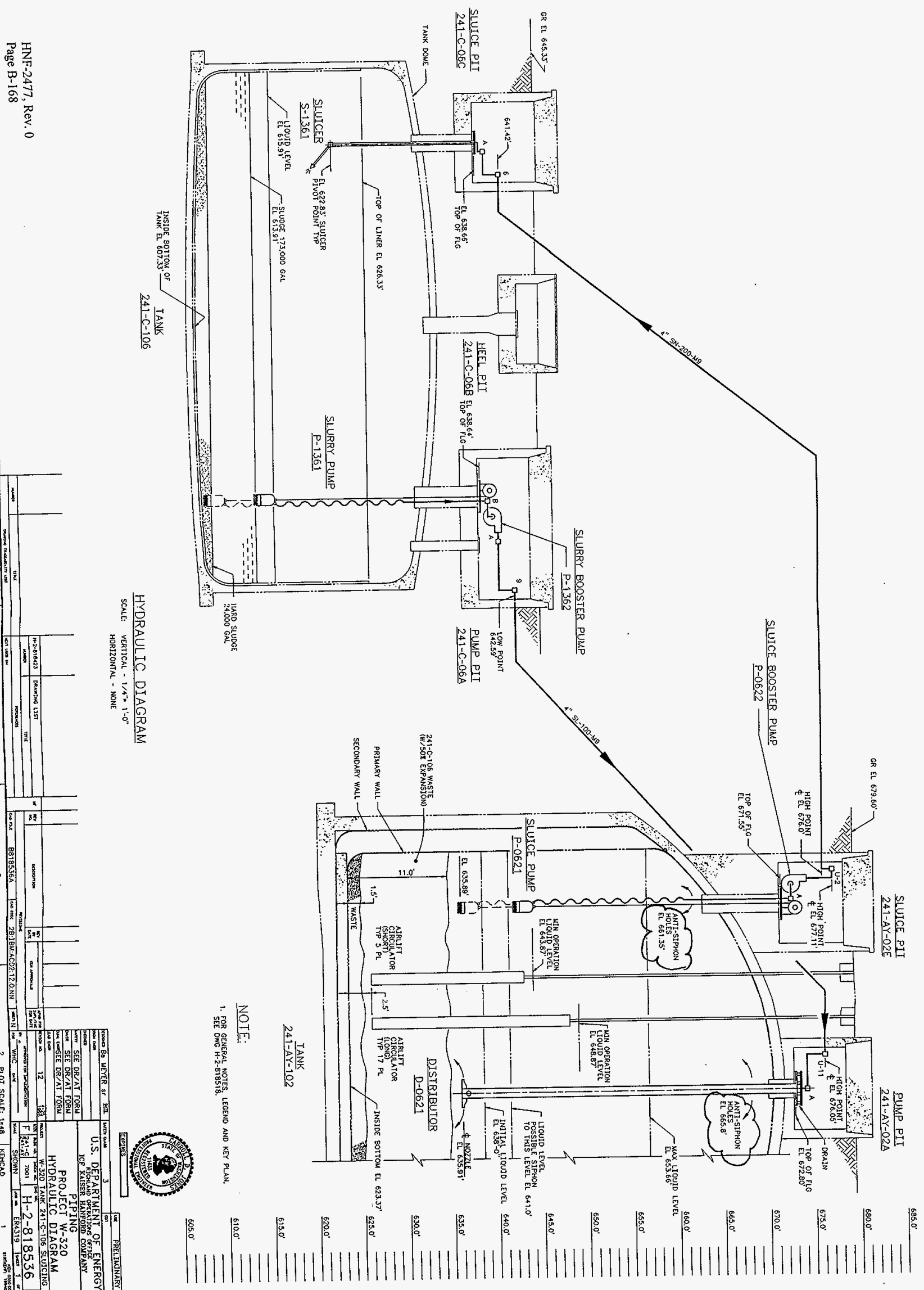


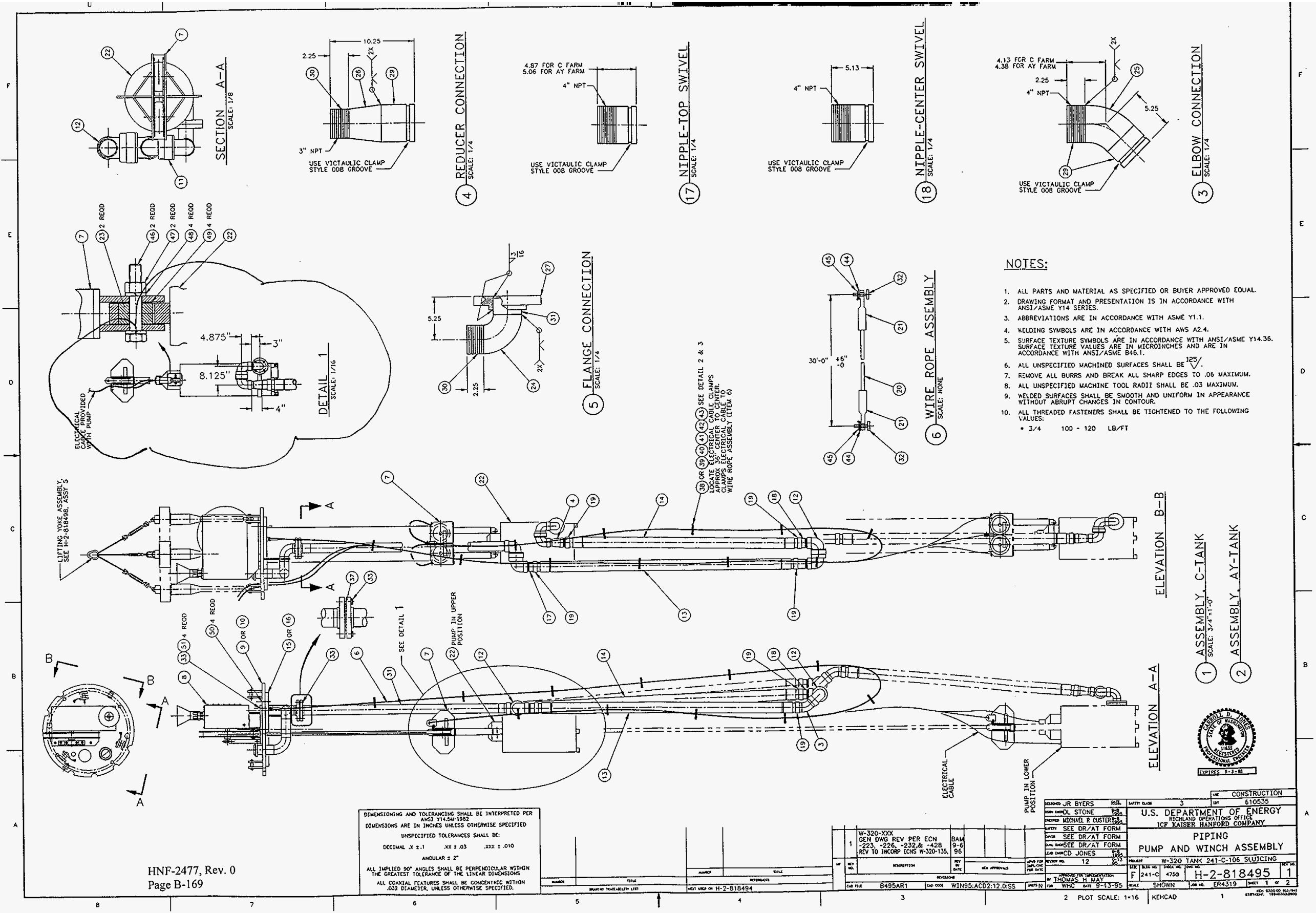



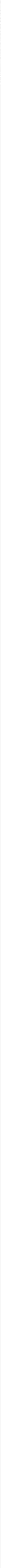

包高题

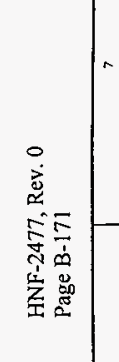




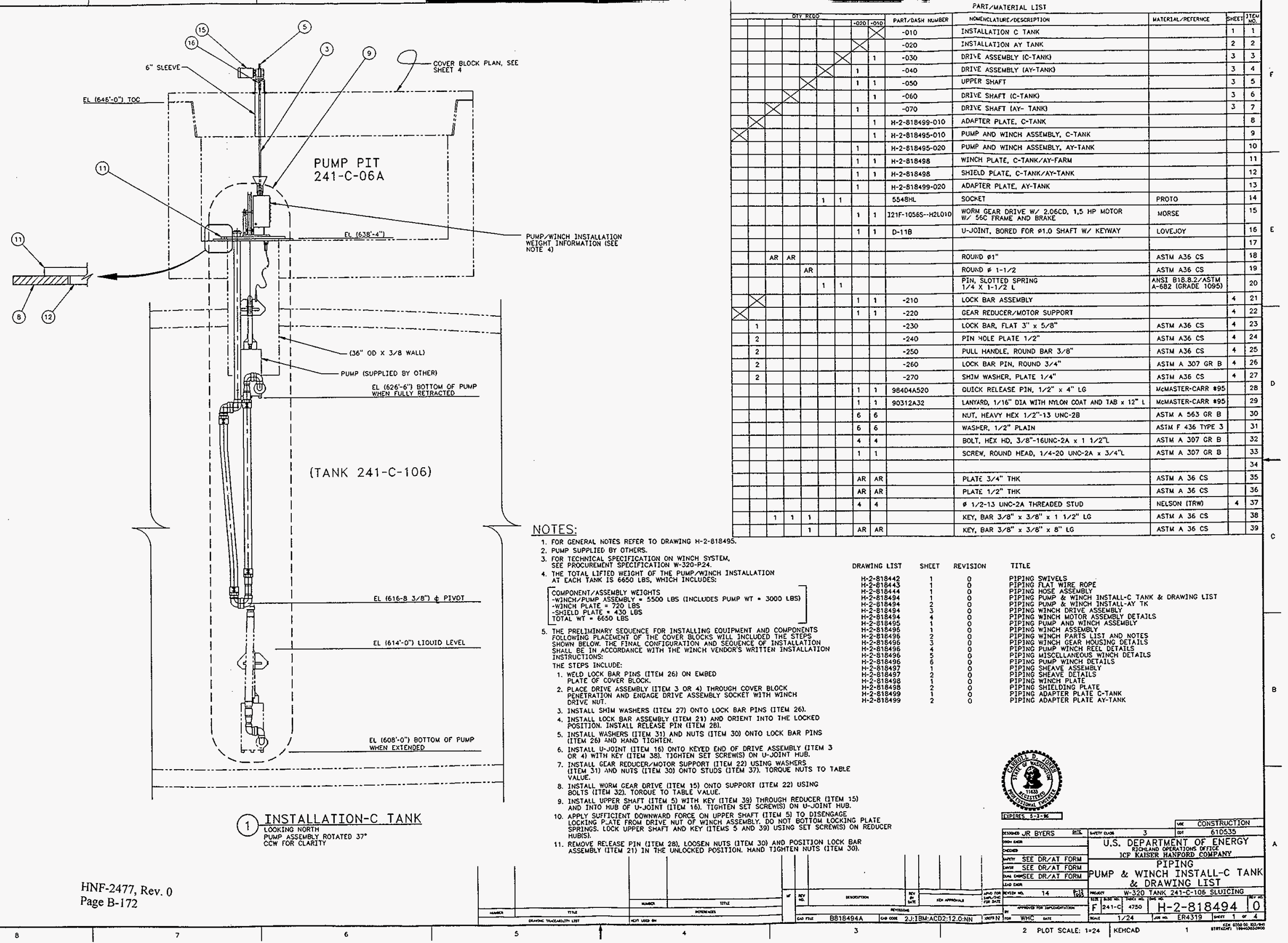




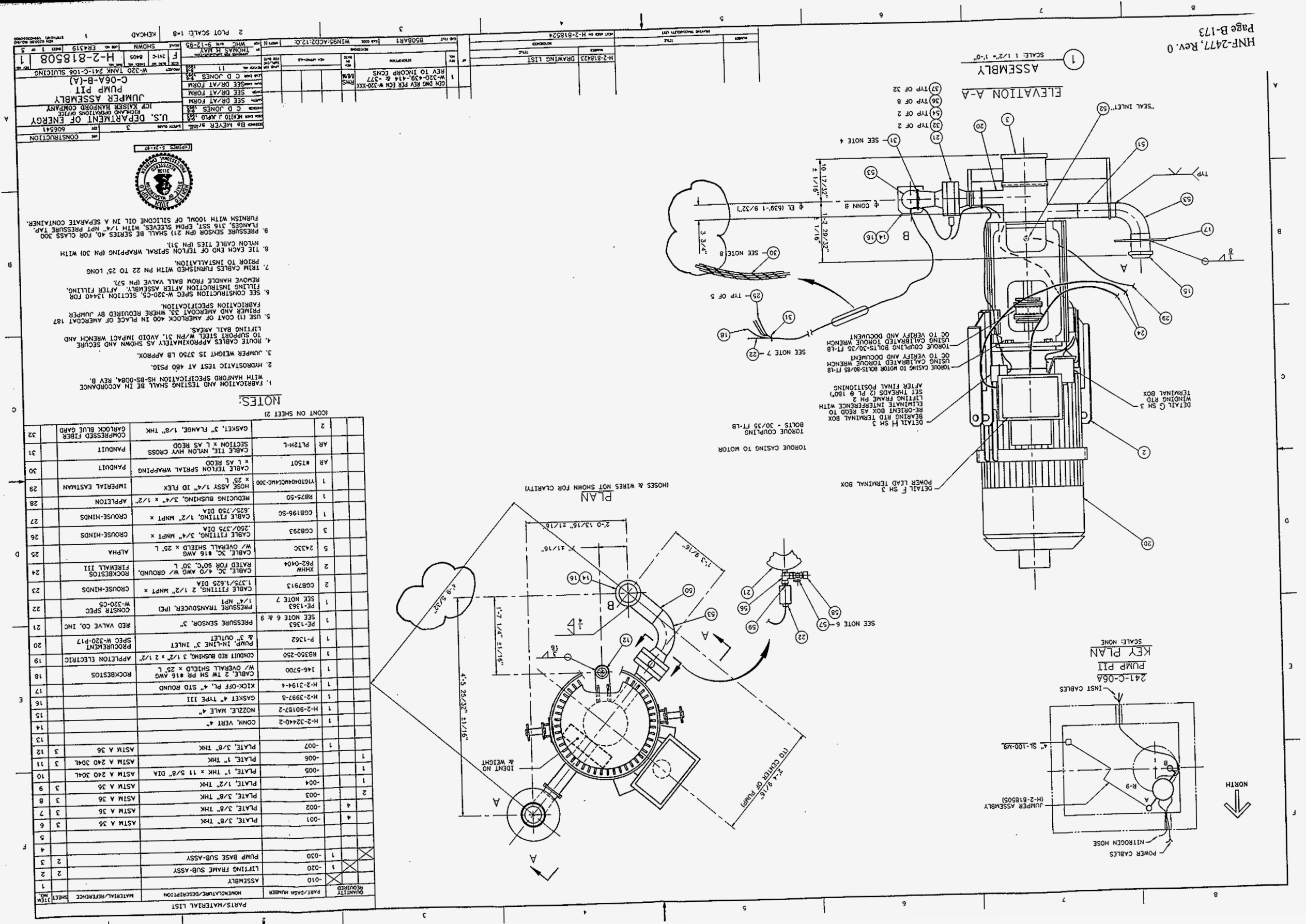




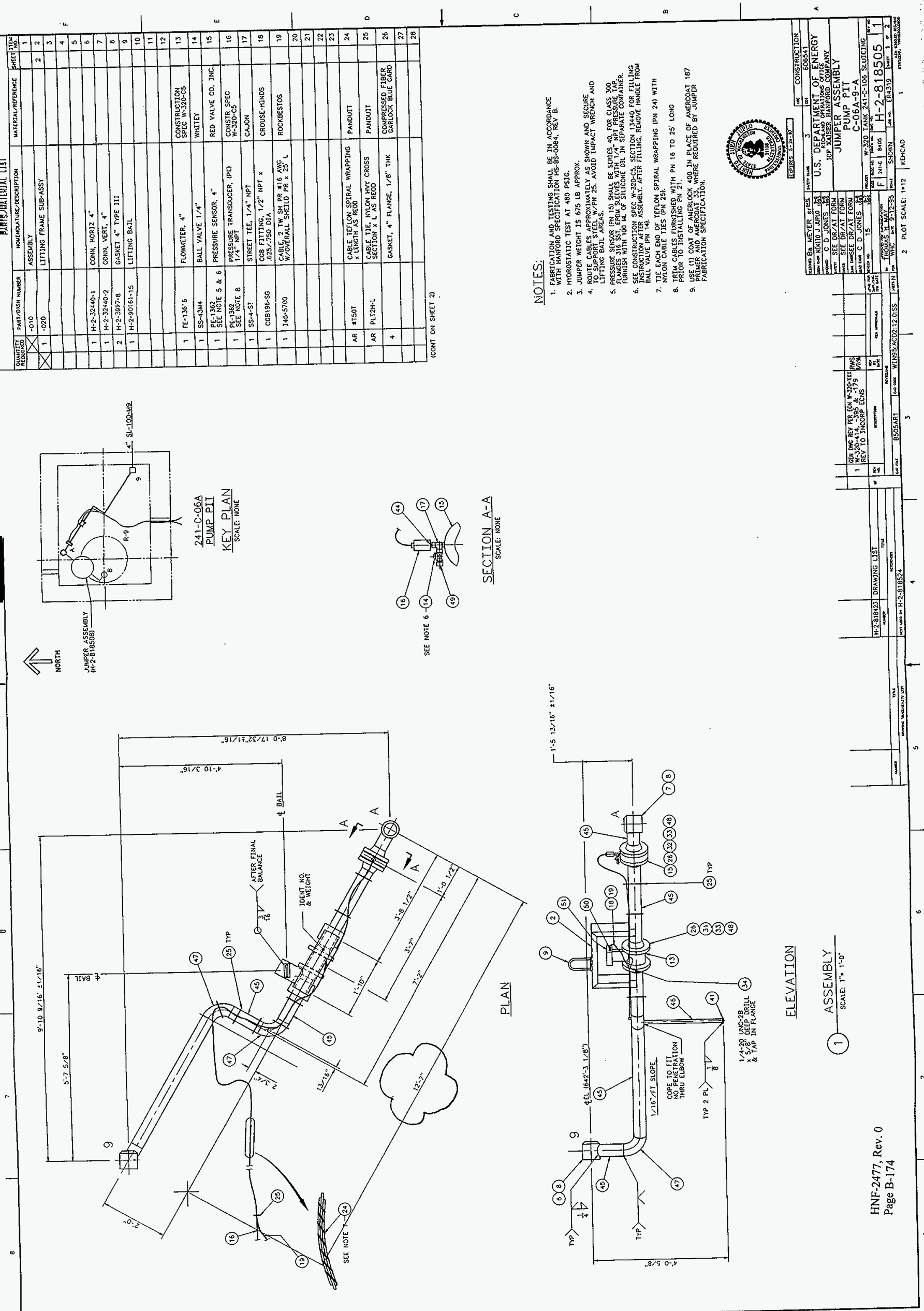




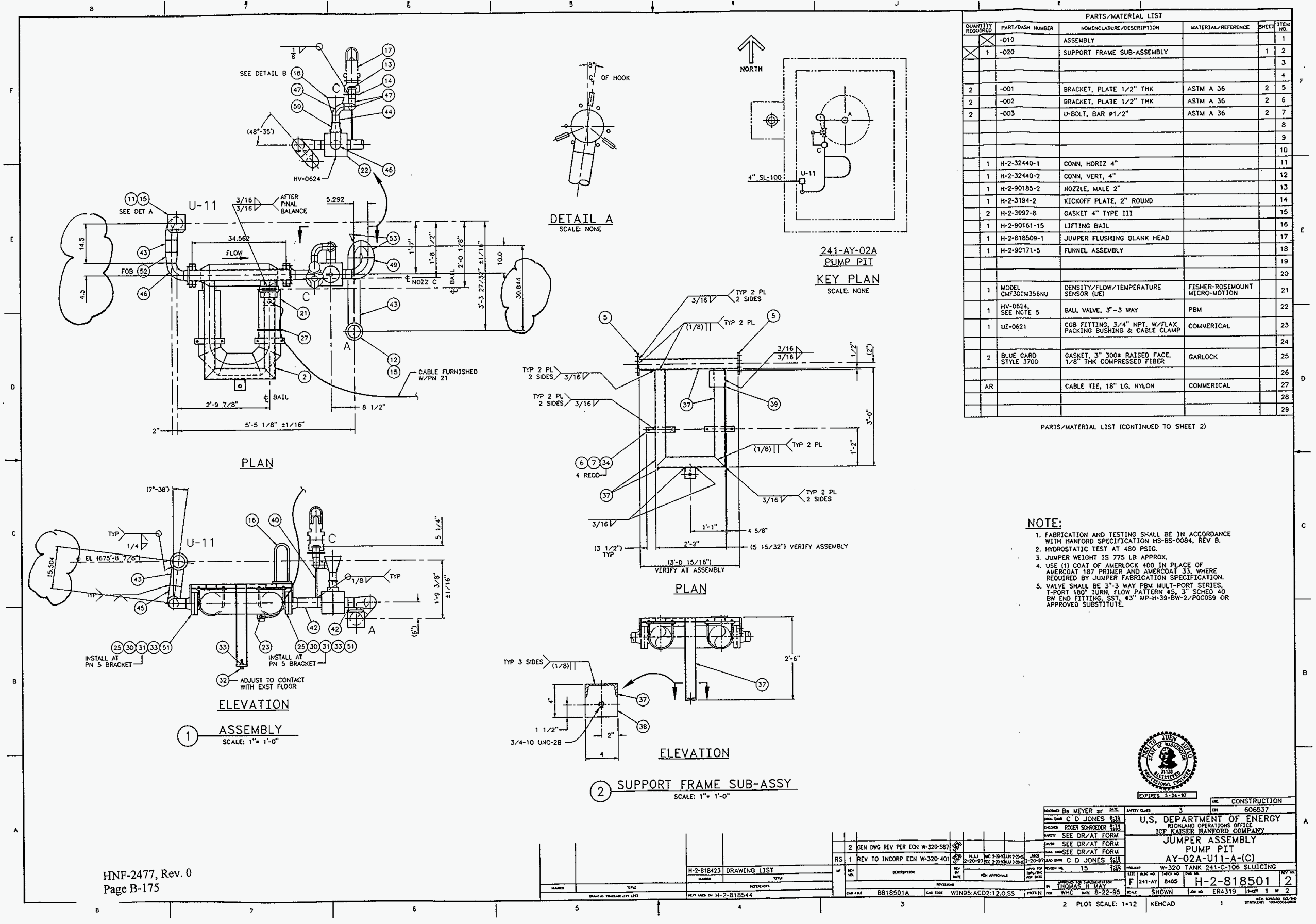




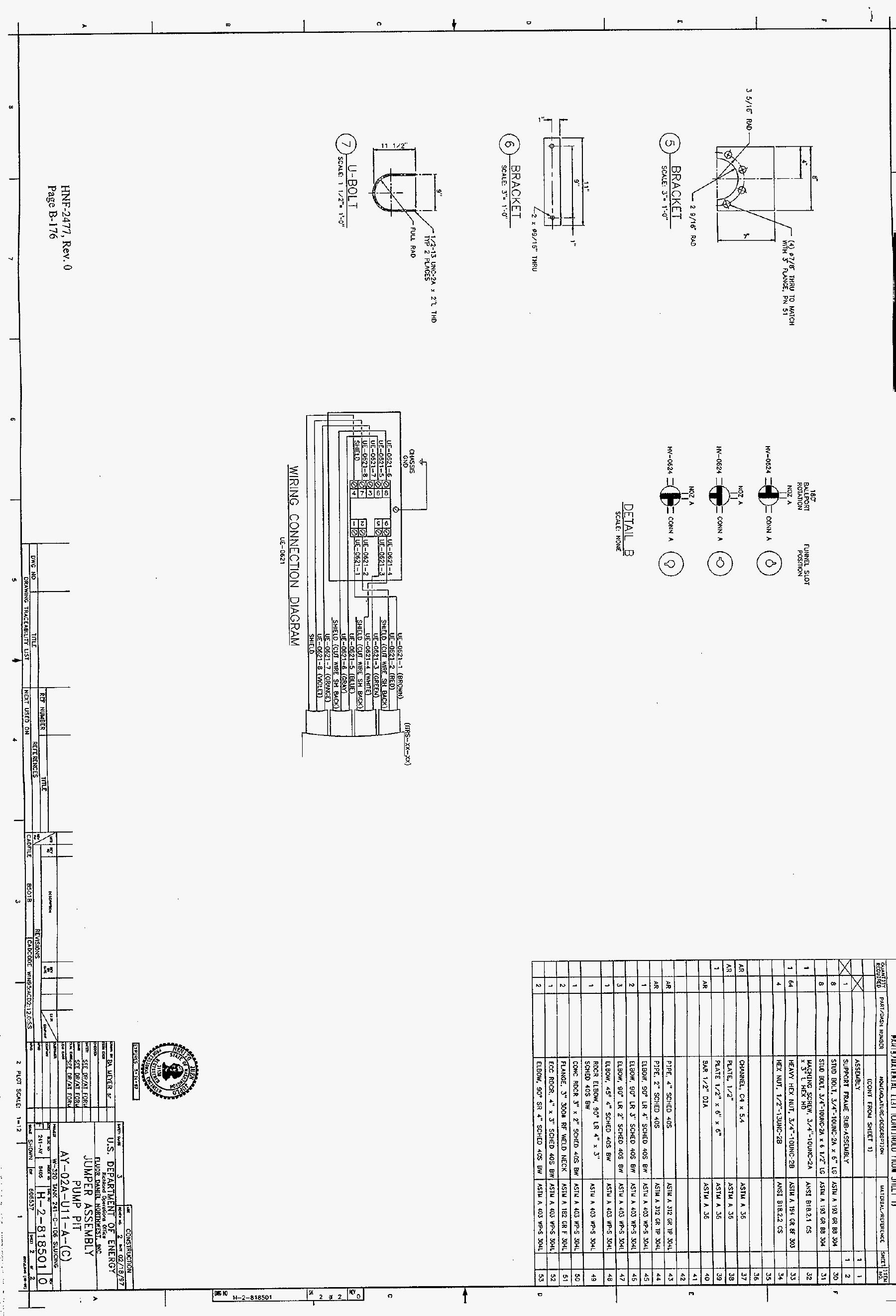




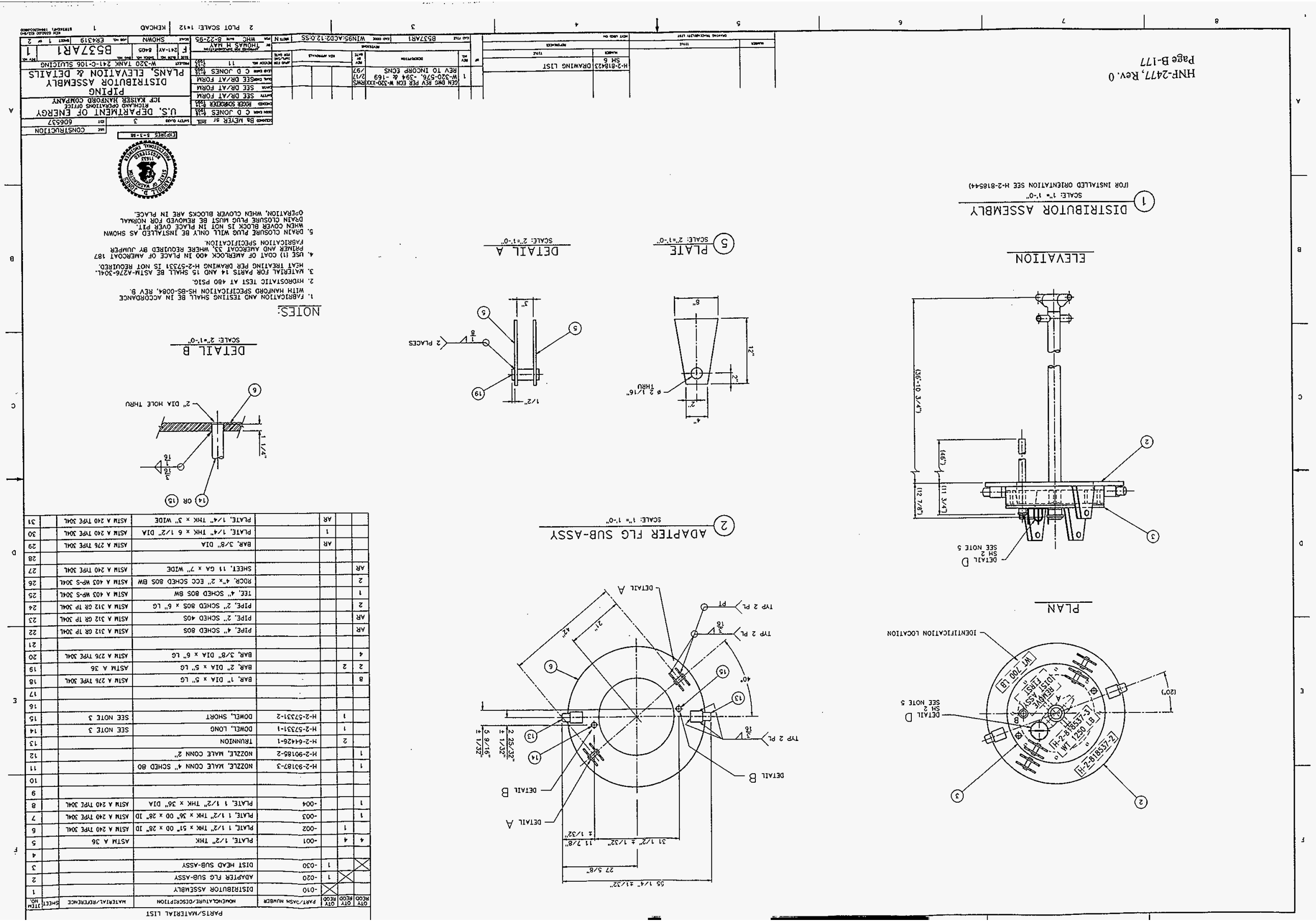



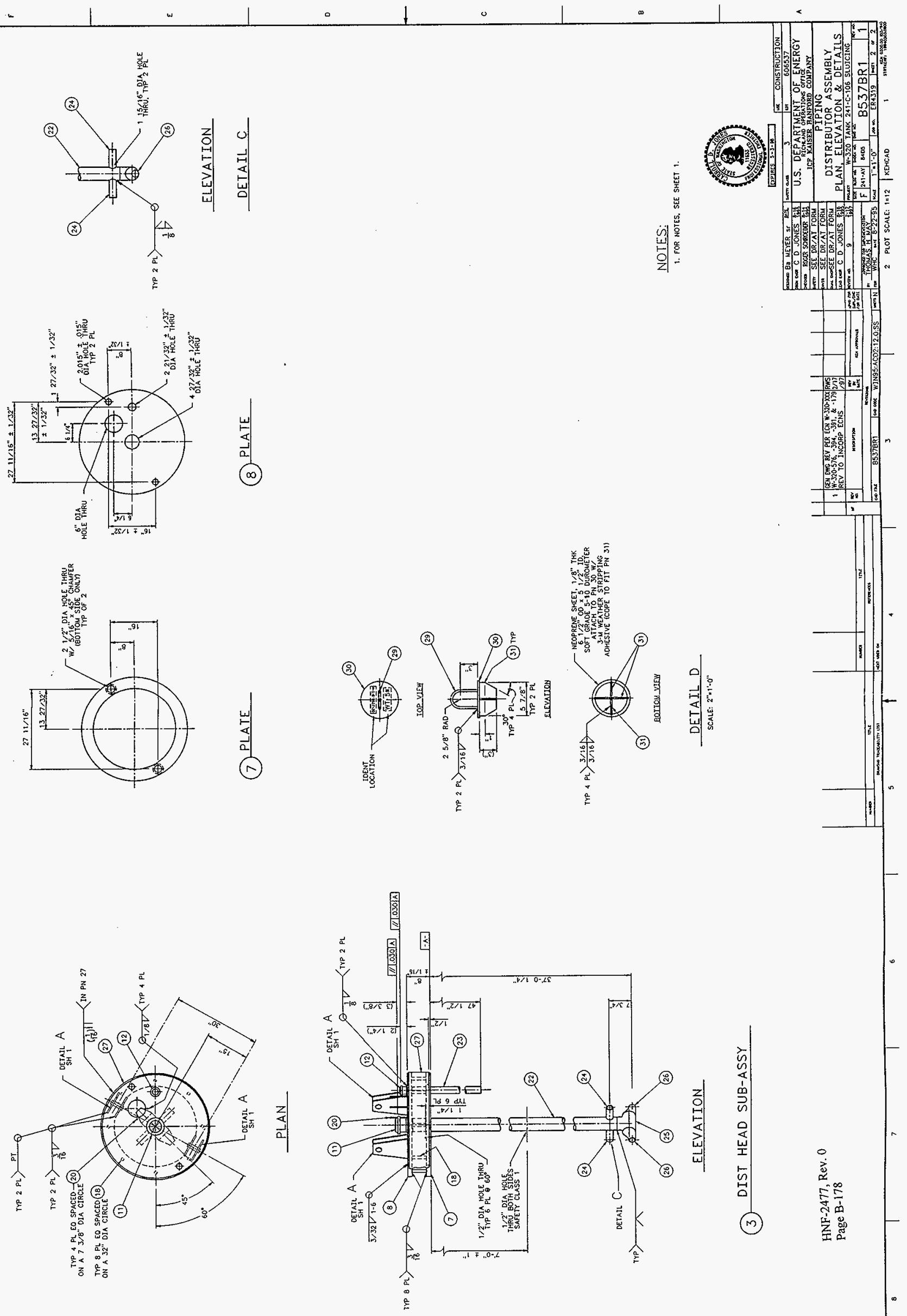

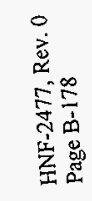




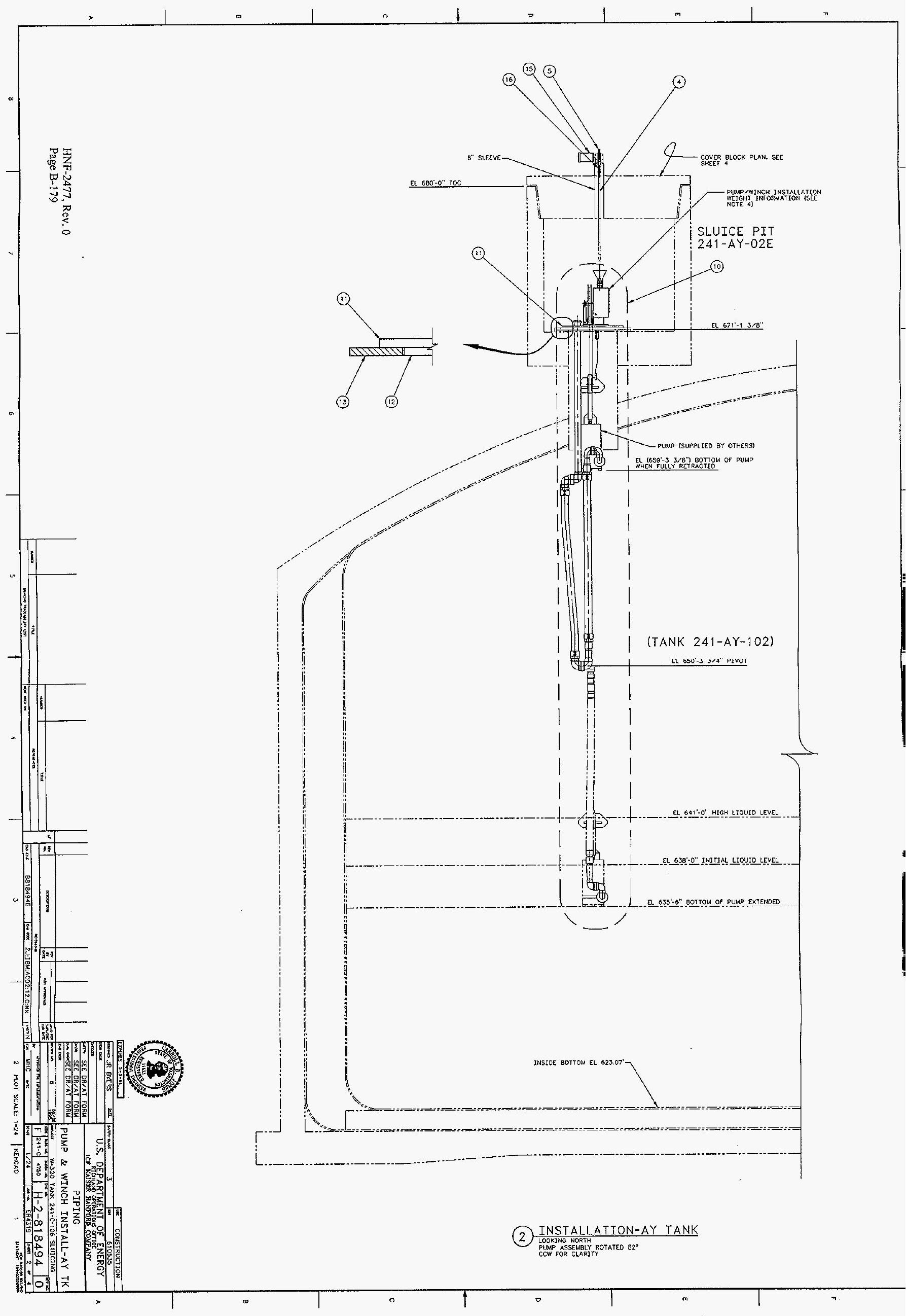




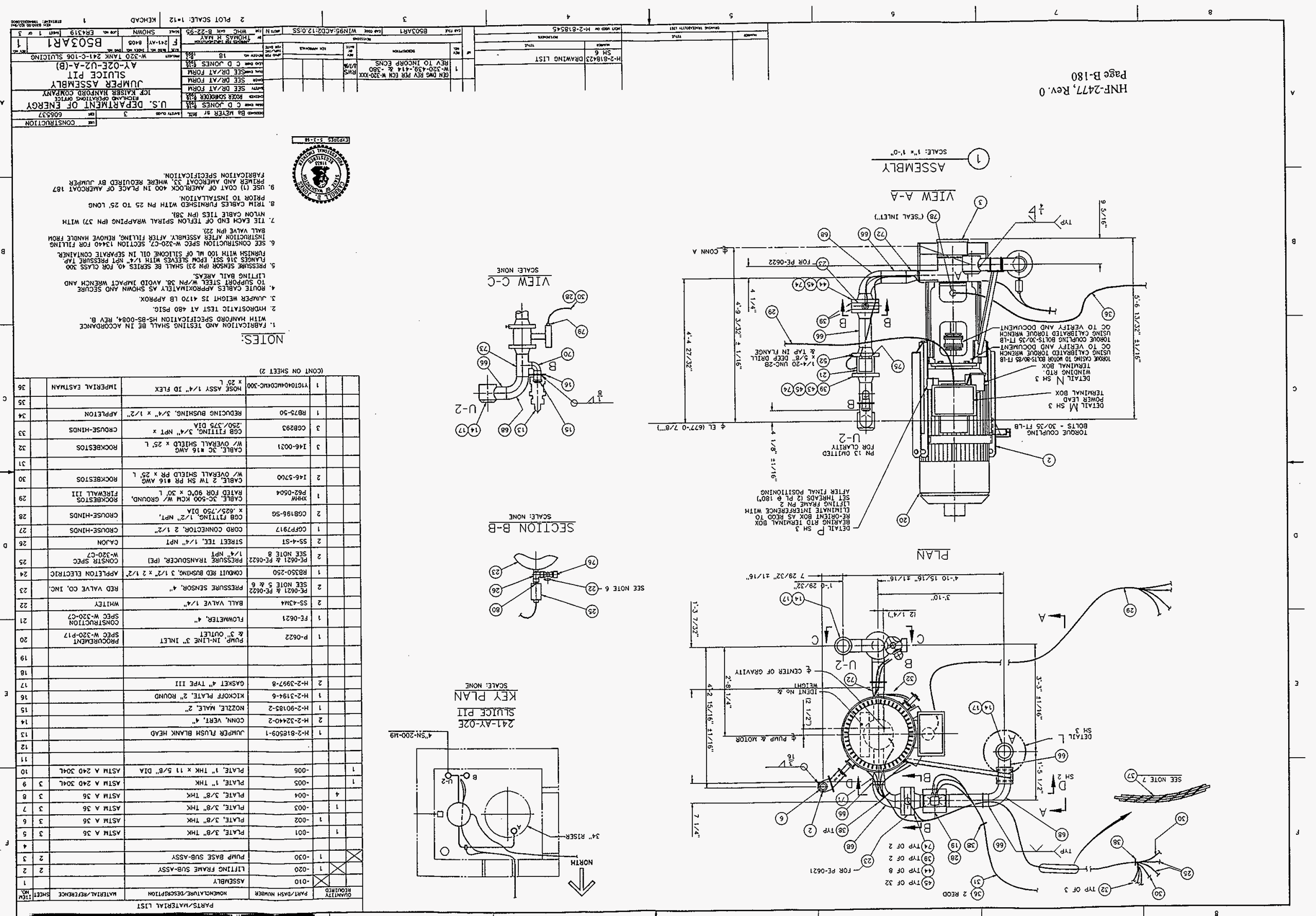




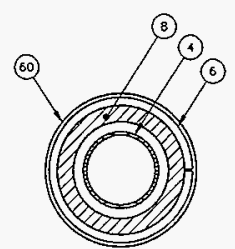

SECTION E-E FROM SH 1.

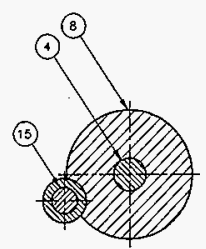

SECTION B-B FroW SH

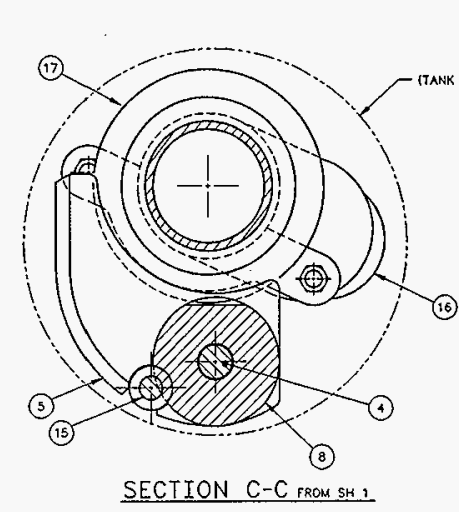

SECTION C-C FROM SH
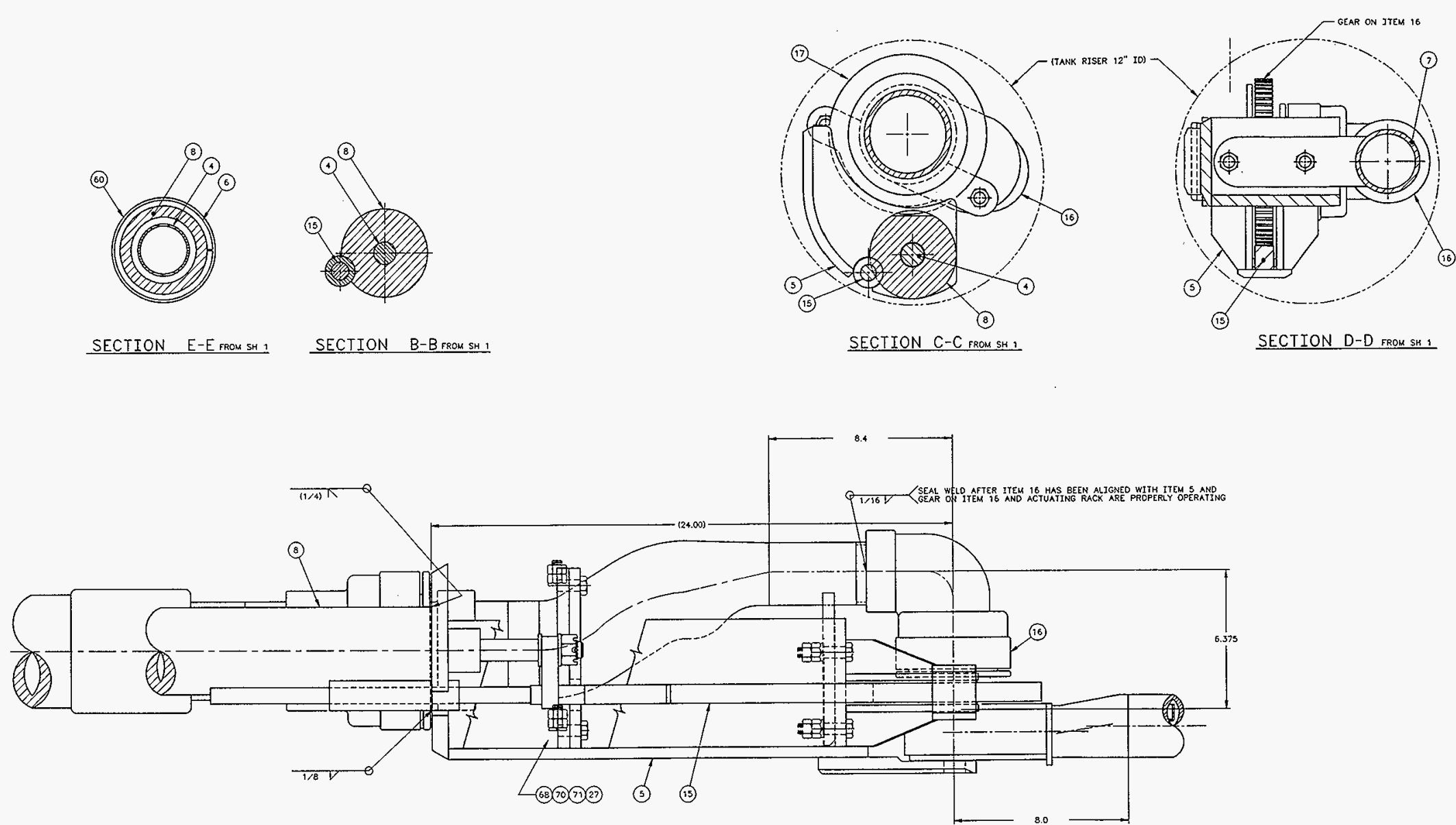

VIEW A-A FROM SH -

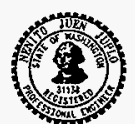

TON TELANDER $\mathrm{NW}$

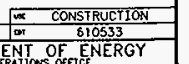

HNF-2477, Rev. 0

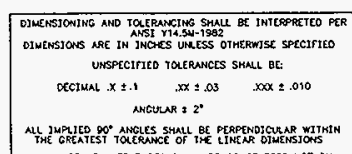
Page B-182

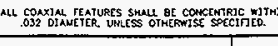

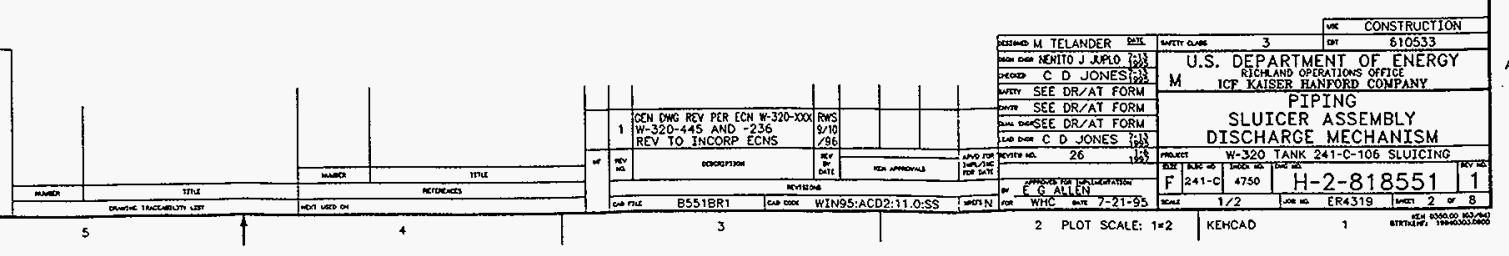




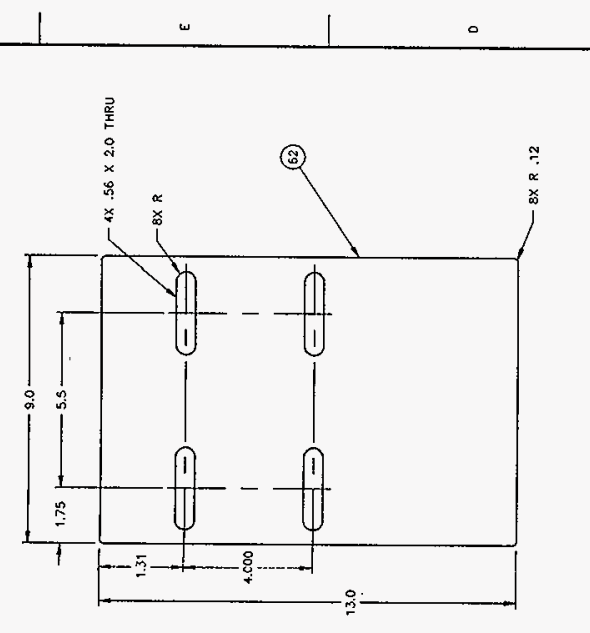

矛
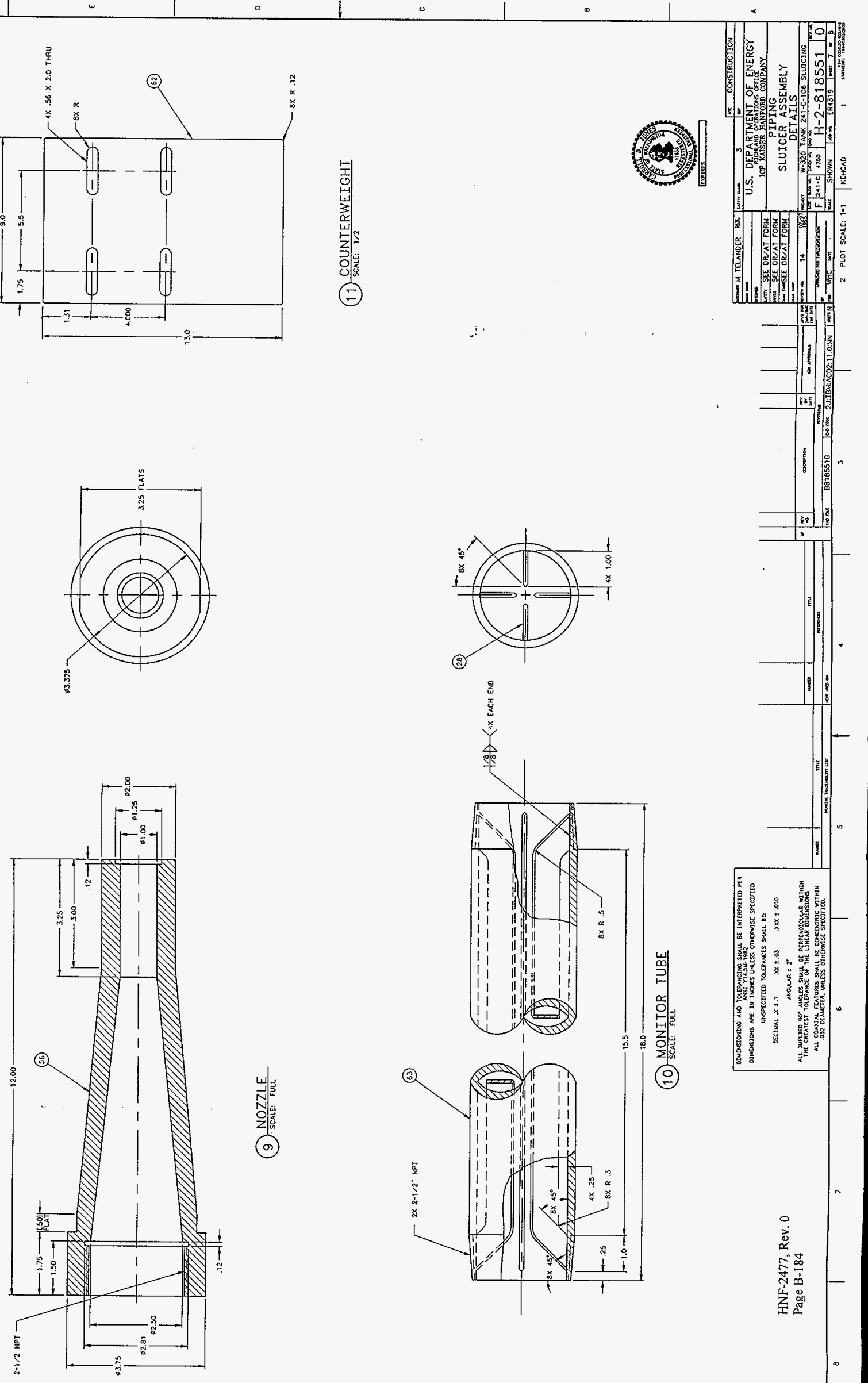
HNF-2477, Rev. 0

W320-27-046

Flushing Nozzle Lifting Force 


\begin{tabular}{|c|c|c|c|}
\hline FLUOR DANIEL & CALCULATION IDENTIFICATION AND INDEX & Page & $i$ of \\
\hline NORTHWEST & & Date & $3 / 26 / 1997$ \\
\hline
\end{tabular}

This sheet shows the status and description of the attached Design Analysis sheets.

\begin{tabular}{ll} 
Discipline & 27 , Piping and Vessels WO/Job No. W320/E09147 Calculation No. W320-27-046 \\
\cline { 2 - 4 } Project No. \& Name & Project W-320 Waste Retrieval for Tank 241-C-106 \\
Calculation ltem & Flushing Nozzle Iifting Force
\end{tabular}

These calculations apply to:

Dwg. No. H-2-818454, Sht. 3, Detail 8

$\begin{array}{llll}\text { Dwg: No. } & \mathrm{H}-2-818501, \text { Sht. I } & \text { Rev. No. } & 1 \\ \text { Other (Study, CDR) } \quad \text { ECN W-320-587 and USQ TF-97-0214 }\end{array}$

Rev. No.

The status of these calculations is:

ㅁ Preliminary Calculations

冈 Final Calculations

C Check Calculations (On Calculation Dated

$\square$ Void Calculation (Reason Voided

Incorporated in Final Drawings?

$\square$ Yes $\square$ No

This calculation verified by independent "check" calculation?

$\square$ Yes $\square$ No

Original and Revised Calculation Approvals:

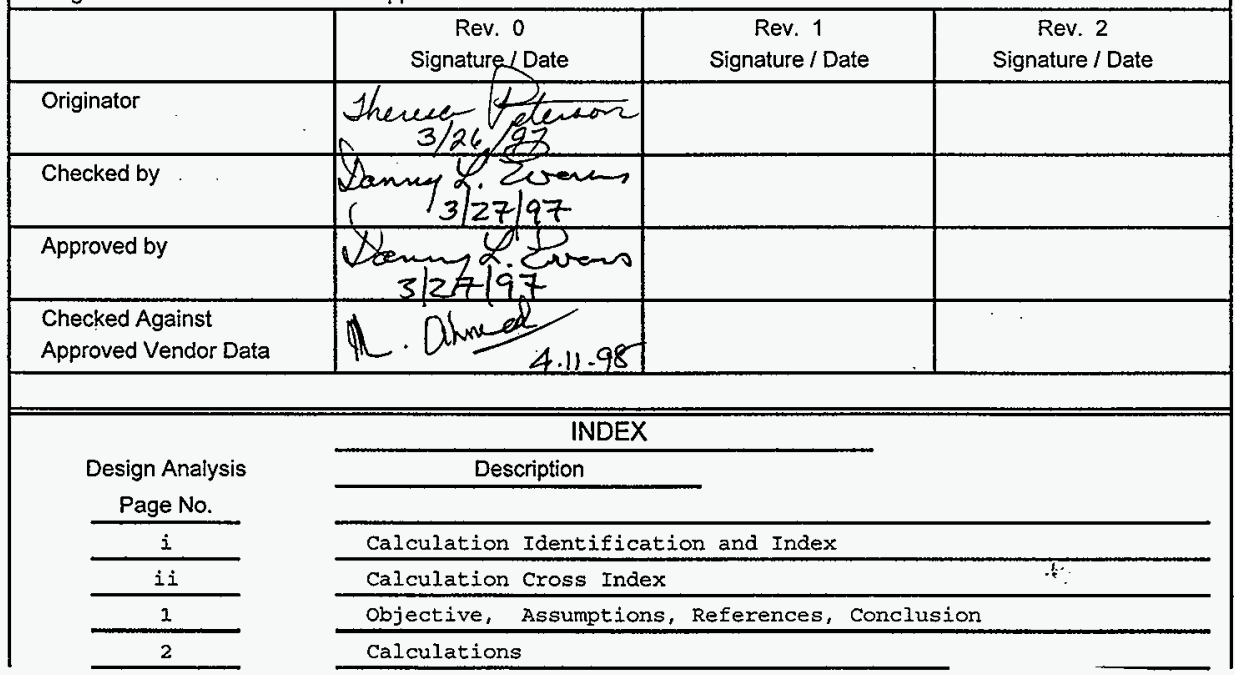


CALCULATION CROSS INDEX

Subject Calculation No. W320-27-046

\begin{tabular}{|c|c|c|c|c|c|c|c|c|c|c|c|}
\hline \multirow{2}{*}{$\begin{array}{l}\text { Subject } \\
\text { Calculation } \\
\text { Revision } \\
\text { No. }\end{array}$} & \multirow{2}{*}{$\begin{array}{c}\text { Superceded } \\
\text { by } \\
\text { Calculation } \\
\text { No. }\end{array}$} & \multicolumn{2}{|c|}{$\begin{array}{l}\text { These interfacing calculation/documents } \\
\text { provide input to the subject calculation, } \\
\text { and if revised may require revision of } \\
\text { the subject calculation. }\end{array}$} & \multicolumn{2}{|c|}{$\begin{array}{l}\text { Results and conclusions of the subject } \\
\text { calculation are used in these interfacing } \\
\text { calculations and/or documents. }\end{array}$} & \multicolumn{2}{|c|}{$\begin{array}{l}\text { Does the output } \\
\text { interface calculation/ } \\
\text { documents require } \\
\text { revision? }\end{array}$} & \multicolumn{2}{|c|}{$\begin{array}{l}\text { Has the output } \\
\text { interface calculation } \\
\text { documents been } \\
\text { revised? }\end{array}$} & \multirow{2}{*}{\multicolumn{2}{|c|}{$\begin{array}{l}\text { Discipline manager's signature } \\
\text { and date indicating evaluation } \\
\text { complete. }\end{array}$}} \\
\hline & & Calcualtion/Document No. & $\begin{array}{l}\text { Revision. } \\
\text { No. }\end{array}$ & Calcualtion/Document No. & $\begin{array}{l}\text { Revision. } \\
\text { No. }\end{array}$ & Yes & No & Yes & No & & \\
\hline & & $\omega-320-27-003$ & 0 & & & & $\mathrm{x}$ & & $x$ & 72,196, & D.enoms \\
\hline & & $\omega-320-27-009$ & 0 & & & & $x$ & & $x$ & $7 / 21 / 98$ & D.L Puans \\
\hline & & & & & & & & & & & \\
\hline & & & & & & & & & & & \\
\hline & & & & & & & & & & & \\
\hline & & & & & & & & & & & \\
\hline & & & & & & & & & & & \\
\hline & & & & & & & & & & & \\
\hline & & & & & & & & & & & \\
\hline & & & & & & & & & & & \\
\hline & & & & & & & & & & & \\
\hline & & & & & & & & & & & \\
\hline & & & & & & & & & & & \\
\hline & & & & & & & & & & & \\
\hline & & & & & & & & & & & \\
\hline & & & & & & & & & & & \\
\hline & & & & & & & & & & & \\
\hline & & & & & & & & & & & \\
\hline & & & & . & & & & & & & \\
\hline
\end{tabular}




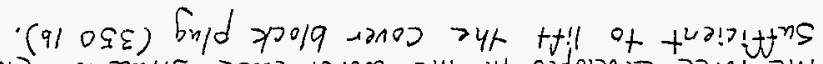

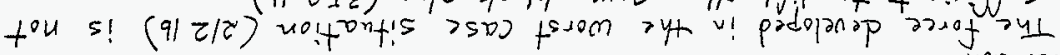

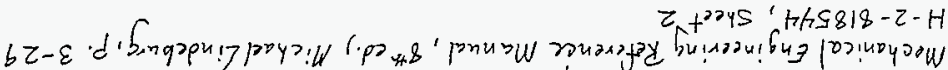

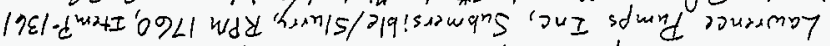

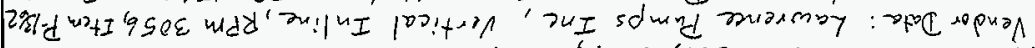

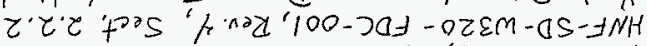
$1+224 s$ '

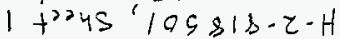

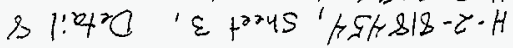
. $\operatorname{sos} 2 \sin \theta$

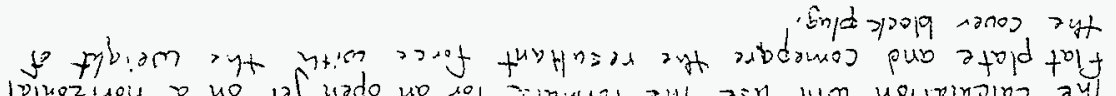

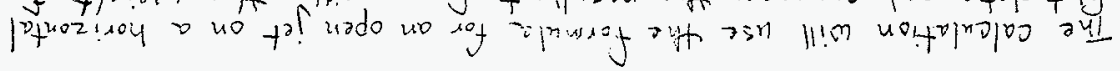

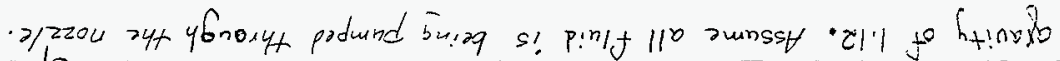

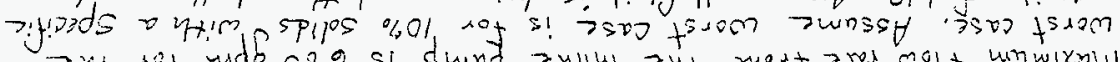

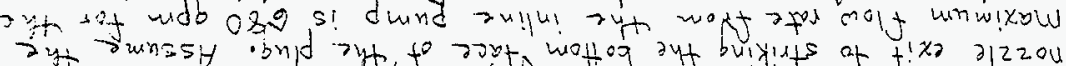

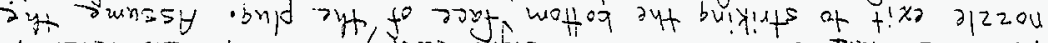

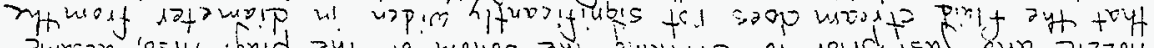

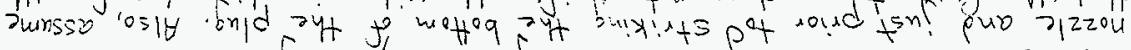

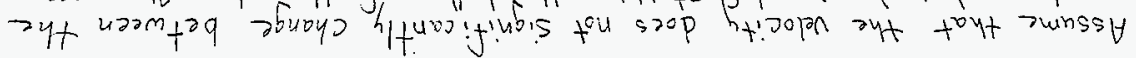

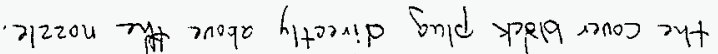

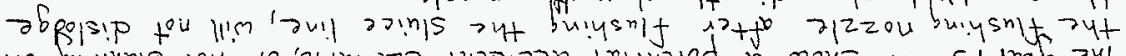

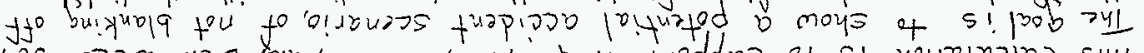

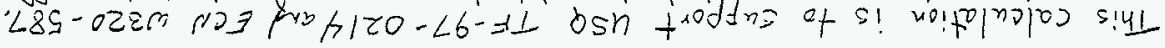

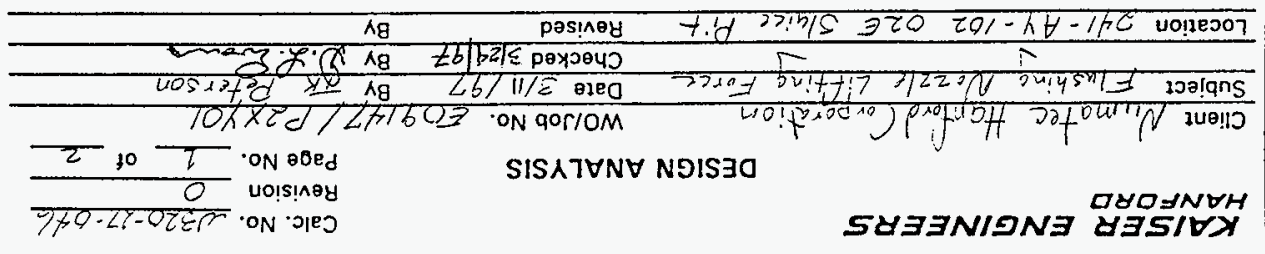




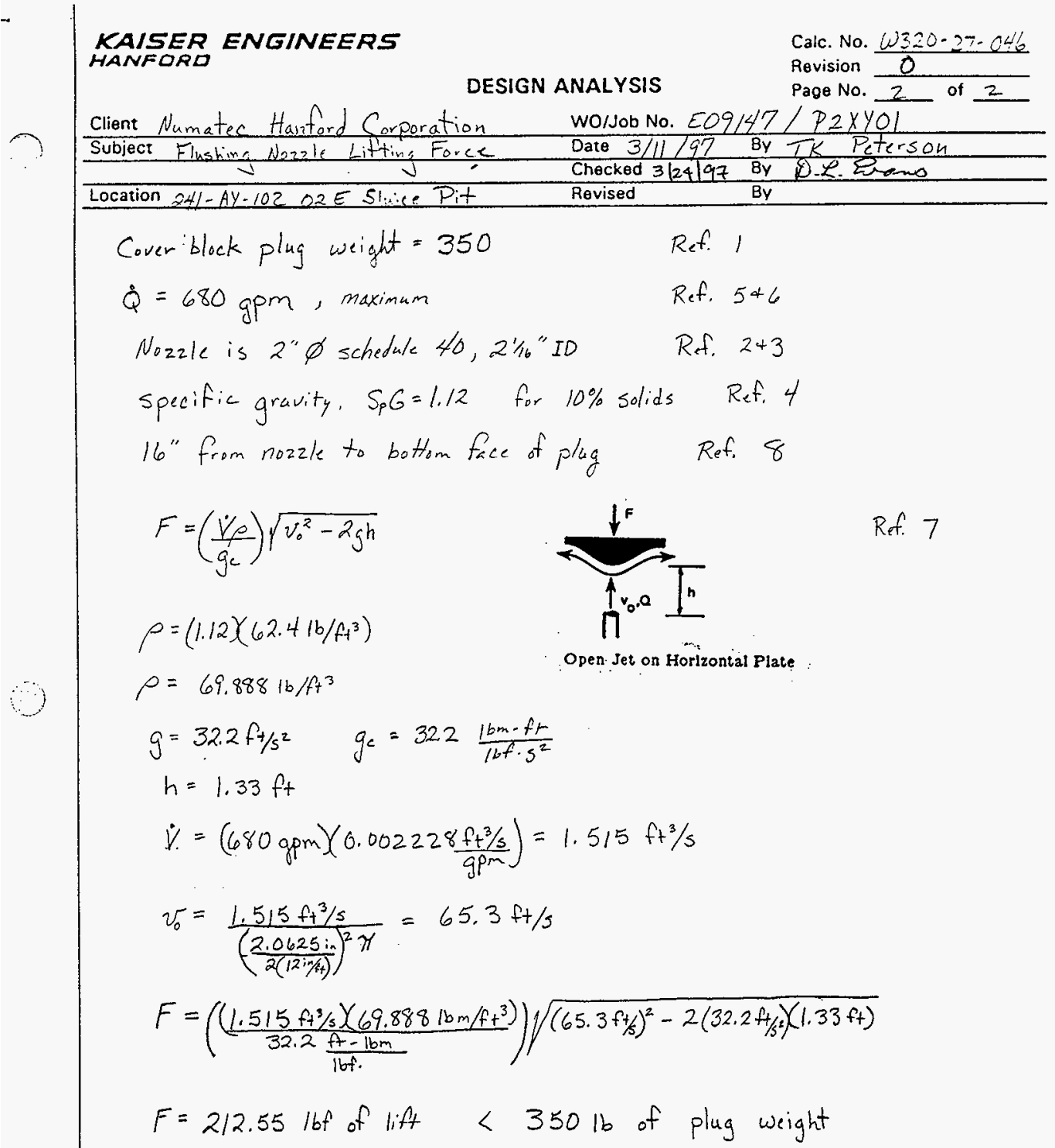

HNF-2477, Rev. 0

Page C-4 


\section{3}

\section{FLUID STATICS AND DYNAMICS}

\section{Nomenclature}

\begin{tabular}{|c|c|}
\hline a & acceleration \\
\hline bhp & brake horsepower \\
\hline$\Lambda$ & area \\
\hline c & speed of sound in fiuld \\
\hline C & $\begin{array}{l}\text { compressibllity, Hazen- } \\
\text { Willams constant, or } \\
\text { coefficient }\end{array}$ \\
\hline d & depth, dlameter \\
\hline $\mathrm{D}$ & dlameter, drag \\
\hline ehp & electrical horsepower \\
\hline $\mathrm{E}$ & bulk modulus, energy \\
\hline f & Darcy friction factor \\
\hline thp & Iriction horsepower \\
\hline $\mathbf{F}$ & force \\
\hline$F_{y c}$ & velocity of approach factor \\
\hline 8 & $\begin{array}{l}\text { local gravitational } \\
\text { acceleration }\end{array}$ \\
\hline $\mathrm{g}_{e}$ & $\begin{array}{l}\text { gravitational constant } \\
(32.2)\end{array}$ \\
\hline
\end{tabular}

G mass flow rate per unit area

h fuld helght, head, depth

$H$ total head

1 moment or Inertia

$k$ ratlo of speciflc heats

$K$ minor loss coefficlent

I length or plpe, litt

$m$ mass

m mass flow rate

n rotational speed

n, specinc speed.

$N_{F}$ Froude number

$\mathrm{N}_{R e} \quad$ Reynolds number

$\mathrm{N}_{W}$ Weber number pressure

power

fow rate

radius

hydraulic radlus

specifle gas constant

\section{$\pi / \mathrm{sec}^{2}$ \\ hp \\ $\mathrm{tt}^{2}$ \\ $\mathrm{tt} / \mathrm{sec}$ \\ $\mathrm{t}^{2} / \mathrm{lb},-,-$ \\ tt \\ tt, Ibr \\ hp \\ $\mathrm{lb} / / \mathrm{ft}^{2}, \mathrm{tt}-\mathrm{Ibf}$ \\ - \\ hp \\ lbr \\ $\mathrm{tt} / \mathrm{sec}^{2}$}

$1 \mathrm{bm}-\mathrm{tr} / \mathrm{Ibr}-\mathrm{sec}^{2}$

$1 \mathrm{bm} / \mathrm{sec}-\mathrm{tt}^{2}$

tt

$\pi$

$\mathrm{tt}^{4}$

$-$

$-$

tt. Ibe

Ibm

$\mathrm{lbm} / \mathrm{sec}$

$\mathrm{rpm}$

$\begin{array}{ll}- & \\ - & \\ - & \mathrm{b} \\ \mathrm{Ibr} / \mathrm{ft}^{2} & \mathrm{c} \\ \mathrm{t}-\mathrm{lbr} / \mathrm{sec} & \mathrm{Dpm} \\ \mathrm{tt} & \mathrm{e} \\ \mathrm{tt} & \mathrm{f} \\ \mathrm{tt}-\mathrm{lbr} / \mathrm{lbm}-{ }^{\circ} \mathrm{R} & \mathrm{I}\end{array}$

\begin{tabular}{|c|c|c|}
\hline s & length & ft \\
\hline S.G. & specifle gravity & - \\
\hline$t$ & time & sec \\
\hline $\mathbf{T}$ & absolute temperature & ${ }^{\circ} \mathbf{R}$ \\
\hline $\mathbf{Y}$ & velocity & $\pi / \sec$ \\
\hline V & volume & $t^{3}$ \\
\hline$\dot{v}$ & volumetric flow rate & $\mathrm{tt}^{3} / \mathrm{sec}$ \\
\hline$w$ & welght & lbt \\
\hline whp & water horsepower & hp \\
\hline$x$ & $x$-coordinate & $\pi$ \\
\hline$y$ & distance, $\boldsymbol{y}$-coordinate & It \\
\hline & belght above datym & tt \\
\hline
\end{tabular}

Symbols

\begin{tabular}{|c|c|c|}
\hline$\beta$ & contact angle, beta ratio & - \\
\hline $\boldsymbol{\gamma}$ & specinc weight & $\mathrm{Ibr} / \mathrm{ft}^{3}$ \\
\hline$\epsilon$ & speclffe roughness & $\pi$ \\
\hline$\eta$ & efflency & - \\
\hline$\theta$ & angle & $\cdot$ \\
\hline$\mu$ & absolute viscosity & $\mathrm{lb}-\mathrm{sec} / \mathrm{tt}^{2}$ \\
\hline$\nu$ & kInematlc viscosity & $\mathrm{tt}^{2} / \sec$ \\
\hline$\rho$ & density & $1 \mathrm{bm} / \mathrm{tt}^{3}$ \\
\hline$\tau$ & shear stress & $\mathrm{Ibf} / \mathrm{st}^{2}$ \\
\hline$T$ & surlace tension & $1 \mathrm{br} / \mathrm{ft}$ \\
\hline$v$ & specific volume & $\mathrm{tt}^{3} / 1 \mathrm{bm}$ \\
\hline$\phi$ & angle, deflection angle & - \\
\hline $\boldsymbol{\omega}$ & rotational speed & $\mathrm{rad} / \mathrm{sec}$ \\
\hline
\end{tabular}

\section{Subscripts}

$\begin{array}{ll}\text { a } & \text { atmospherlc } \\ \text { A } & \text { added } \\ \text { b } & \text { blade } \\ \text { c } & \text { centroid, contraction } \\ \text { d } & \text { discharge } \\ \text { D } & \text { drag } \\ \text { e } & \text { equivalent, entrance } \\ \text { E } & \text { English, extracted } \\ \text { f } & \text { inlction, flow } \\ \text { I } & \text { inslde, inlet }\end{array}$


3. $F$ and $x$ are positive to the right. $F$ and $y$ are positive upward.

4. $F$ is the force on the nuid. The force on the walls or support has the same magnitude but opposite direction.

5. The fiuld is assumed to flow horizontally from left to right and is assumed to possess no $y$ component of velocity.

The momentum possessed by a moving fiuld is defined as the product of mass (in slugs) and velocity (in tt/sec). The $g_{c}$ term in equation 3.146 is needed to convert pounds-mass Into slugs.

$$
\text { momentum }=\frac{m v}{g_{e}}
$$

Impulse is defined as the product of a force and the length of time the force is applied.

$$
\text { Impulse }=F \Delta t
$$

The impulse-momentum principle states that the $1 \mathrm{~m}$ pulse applled to a moving body is equal to the change in momentum. This is expressed by equation 3.148 .

$$
F \Delta t=\frac{m \Delta v}{g_{c}}
$$

Solving for $F$ and combining $m$ and $\Delta t$ ylelds equation 3.149 .

$$
F=\frac{m \Delta v}{g_{c} \Delta t}=\frac{\dot{m} \Delta v}{g_{c}}
$$

Since $F$ is a vector, it can be broken into its components

$$
\begin{aligned}
& F_{x}=\frac{\dot{m} \Delta v_{x}}{g_{c}} \\
& F_{y}=\frac{\dot{m} \Delta v_{y}}{g_{c}}
\end{aligned}
$$

If the fuld now is directed through an angle $\phi$,

$$
\begin{aligned}
& \Delta v_{z}=v(\cos \phi-1) \\
& \Delta v_{y}=v \sin \phi
\end{aligned}
$$

There are several nuld appllcatlons of the impulsemomentum princlple.

\section{A. JET PROPULSION}

$$
\begin{aligned}
\dot{m}_{2}=\dot{m}_{1}+\dot{m}_{\text {fuel }} & =\dot{V}_{1} \rho_{1}+\dot{V}_{\text {fuel }} \rho_{\text {fuel }} \\
F_{z} & =\frac{\dot{V}_{2 \rho_{2} v_{2 z}-\dot{V}_{1} \rho_{2} v_{1 z}}}{g_{c}} \\
F_{y} & =\frac{\dot{V}_{2} \rho_{2} v_{2 y}-\dot{V}_{1} \rho_{1} v_{1 y}}{g_{c}}
\end{aligned}
$$

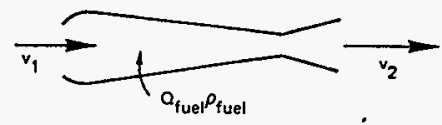

Figure 3.27 Jet Propulsion

B. OPEN JET ON VERTICAL FLAT PLATE

$$
\begin{aligned}
\Delta v_{y} & =0 \\
\Delta v_{x} & =-v \\
F_{x} & =\frac{-\dot{m} v}{g_{e}}=\frac{-\dot{V} \rho v}{g_{e}}
\end{aligned}
$$

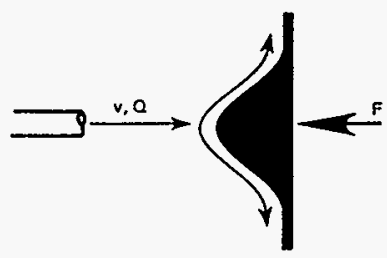

Figure 3.28 Open Jet on Vertlcal Plate

\section{OPEN JET ON HORIZONTAL FLAT PLATE}

As the Jet travels upwards, its velocity decreases since gravity is working against it. By the tlme the liquld has reached the plate, the velocity has become

$$
\begin{aligned}
v_{\nu} & =\sqrt{v_{0}^{2}-2 g h} \\
\Delta v_{z} & =0 \\
\Delta v_{\nu} & =-\sqrt{v_{0}^{2}-2 g h} \\
F & =\left(\frac{-\dot{m}}{g_{c}}\right) \sqrt{v_{0}^{2}-2 g h} \\
& =\left(\frac{\dot{V_{\rho}}}{g_{e}}\right) \sqrt{v_{0}^{2}-2 g h}
\end{aligned}
$$

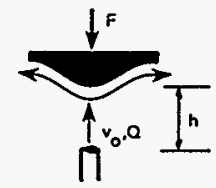

Figure 3.29 Open Jet on Horizontal Plate

\section{OPEN JET ON SINGLE STATIONARY BLADE}

$v_{2}$ may not be the same as $v_{1}$ if friction is present. If no information is given, assume that $v_{2}=v_{1}$.

$$
\begin{aligned}
& \Delta v_{x}=v_{2} \cos \phi-v_{1} \\
& \Delta v_{y}=v_{2} \sin \phi
\end{aligned}
$$


Sluice

L

LAWRENCE PUMPS INC.

371 MARKET STREET, LAWRENCE, MA 01843-9966 17一

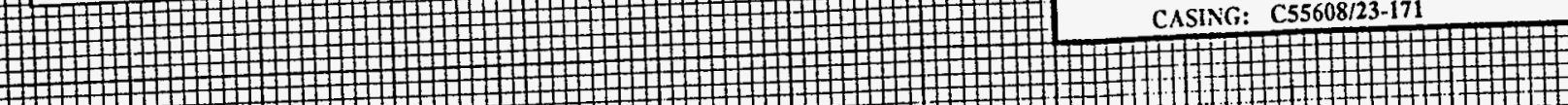

$640+$ Y \begin{tabular}{|l}
\hline $\mathbf{Y}$ \\
$\mathrm{C}$
\end{tabular}

560

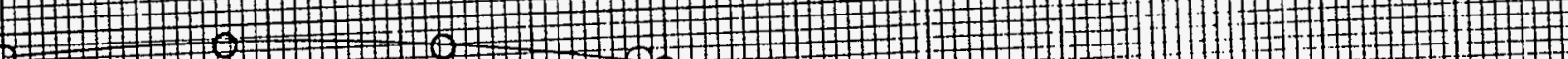

480

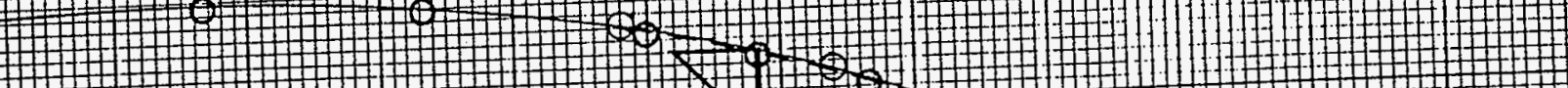
I \begin{tabular}{l}
$\mathrm{C} ㇒$ \\
\hline
\end{tabular}

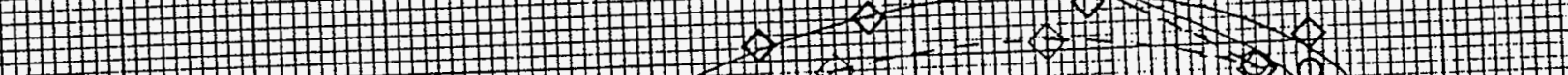

$400 ¥$

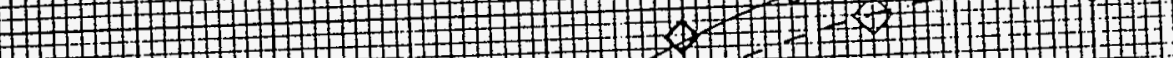

密 320 17

İ

1

I

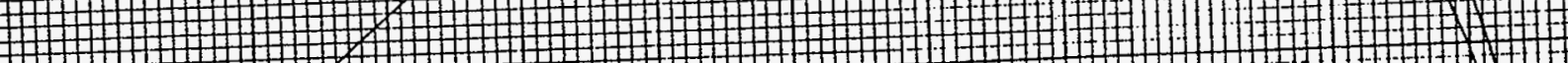

240

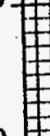

160

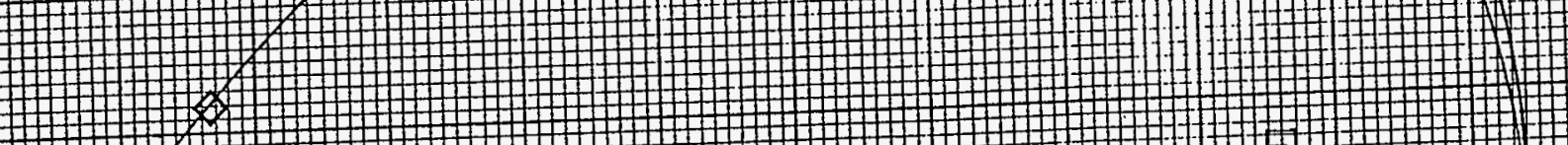

80 I

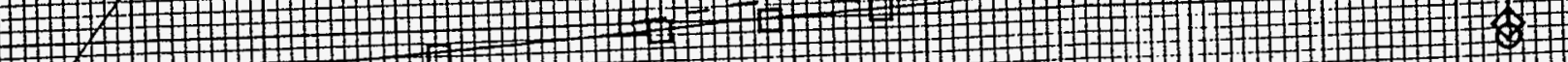
彭

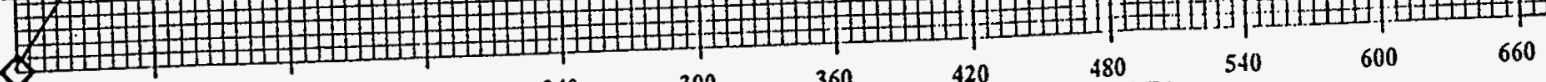
60 120

180 240 $\stackrel{300}{300} \stackrel{360}{36} \stackrel{420}{480}$ CAPACITY-GALLONS PER MINUTE (U.S.)
CUSTOMER: WESTINGHOUSE HANFORD USER NAME: WESTINGIYOUSE IIANFORD P.0. NUMBER: MZA-XVV-78259
SERIAL NUMBER: 91232-1 PUMP TYIE: VERTICAI, INLINE PUMP SIZE: $3 \times 3 \times 13$ SERVICE: RADIOACTIVE SLURRY
MIPI FR POTTEN (IN): 13.00 RATED FI.OW (GPM): 350 RATIEN II:AD) (F): 512
SPEED (RPM): 3056 IMP DIA. MIN (IN): 9.00 IMP DIA. MAX (IN): 13.00 V(P EYE AKEA (IN'2):
TOTAL, DYNAMIC HEAD

$\diamond$ EFFICIENCY

IIIP AT 1.12 SP.GR.

TTED: FYX

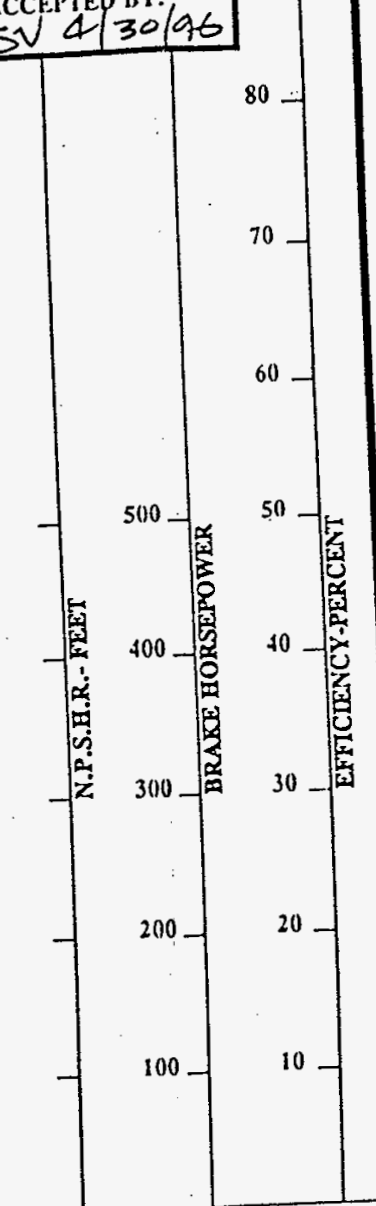




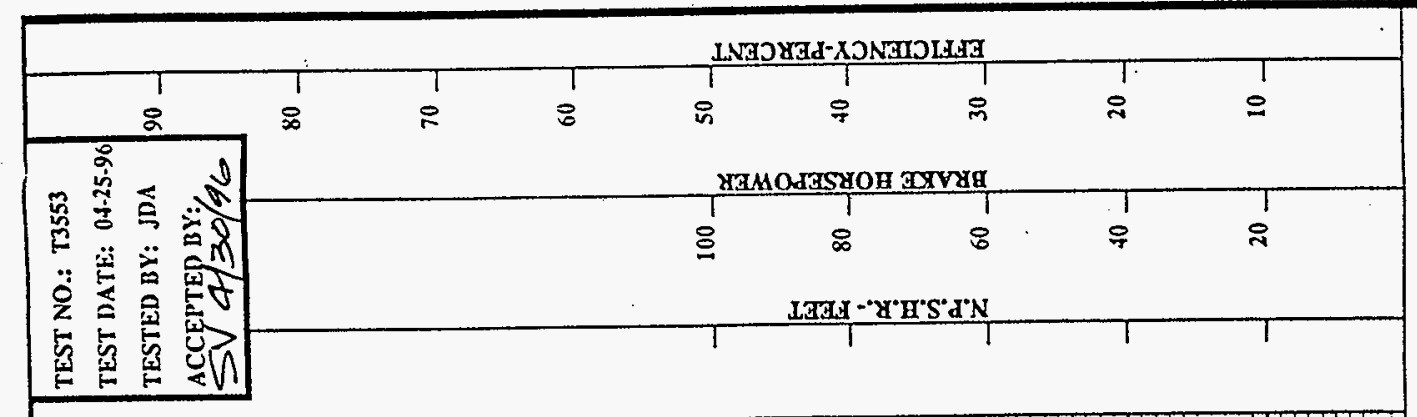

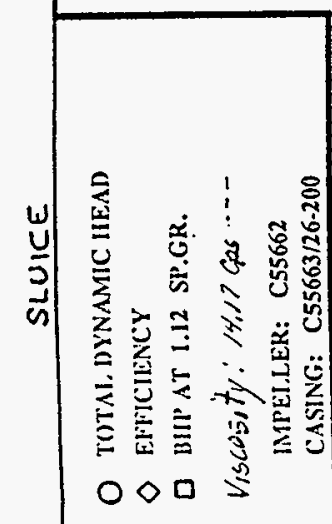

开

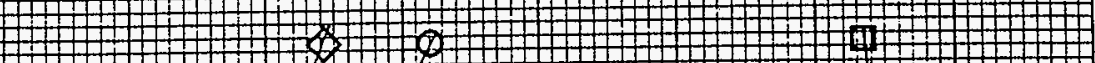

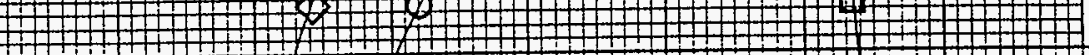
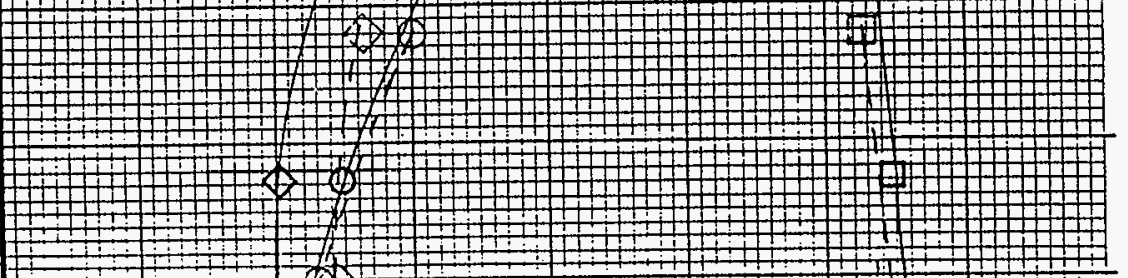

:

용

宅

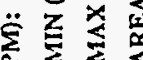

这安

可国

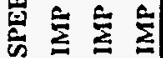

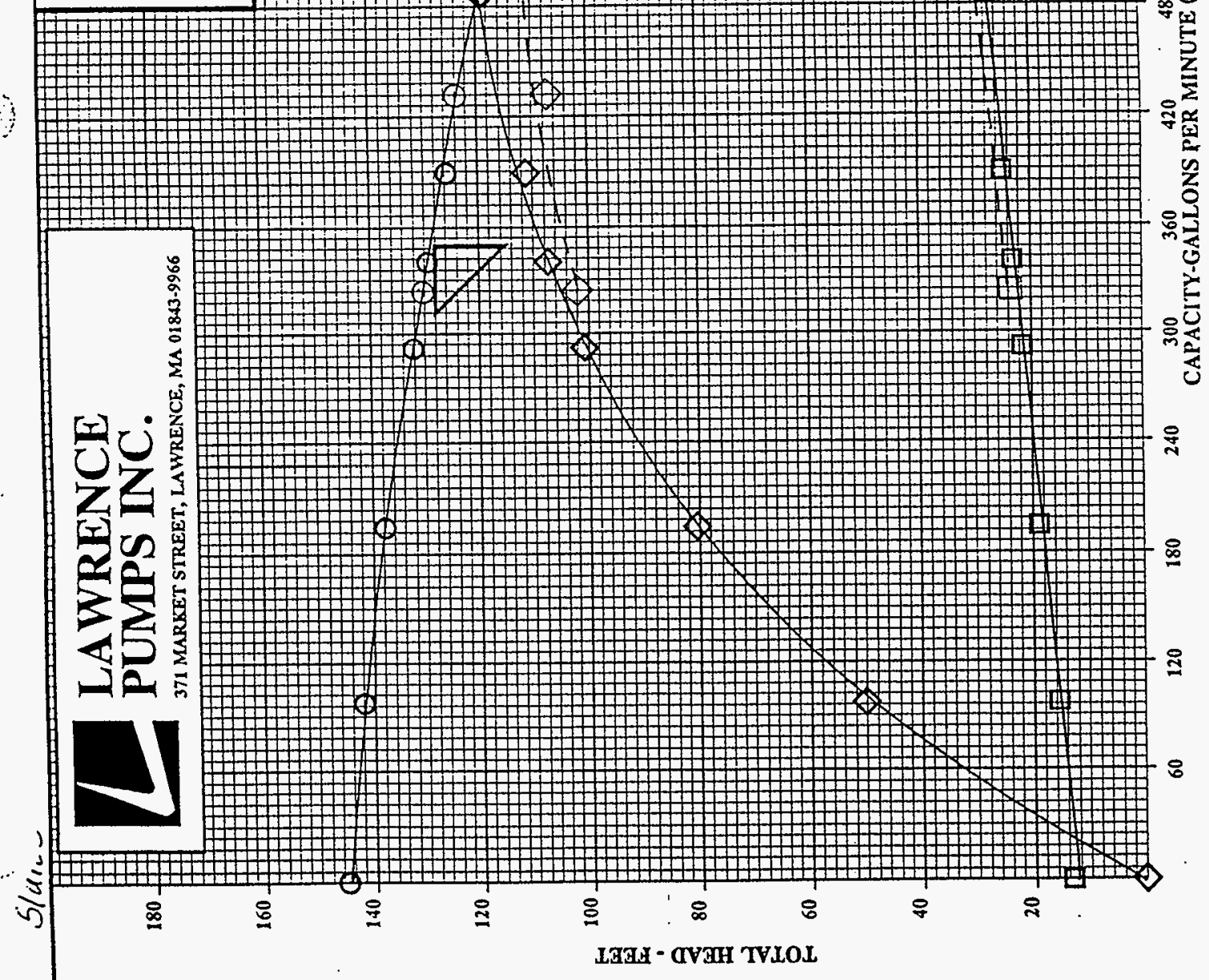

.

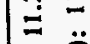

药

范

总苛

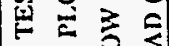

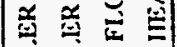

$=$

$-$

焉奋食

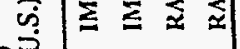

띤

Z

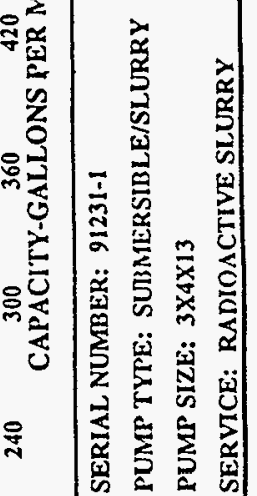

$\underset{\infty}{\infty}$

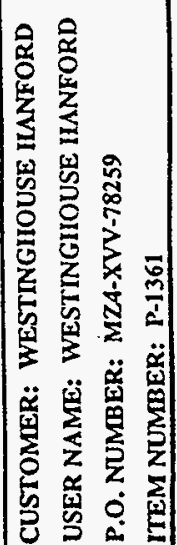


HNF-2477, Rev. 0

W320-27-047

W-320 Pit Volumes and In-0ut Areas

D- $\mathbf{j}$ 
This sheet shows the status and description of the attached Design Analysis sheets.

Discipline: PIPING/VESSALS WO/Job No.: EO9142/W-320

Calculation No.: W320-27-047

Project No. \& Name: PROJECT W-320, TANK 241-C-106 SLUICING

Calculation item: W-320 PIT VOLUMES AND IN-OUT AREAS,

241-C-106 (Pits 06A and 06C), 241-AY-102 (Pits 02A and 02E)

These calculations apply to:

Dwg. No. None

Dwg. No. None

Other (Study, CDR): None

Rev. No. N/A

Rev. No. N/A

Rev. No. N/A

The status of these calculations is:

[] Preliminary Calculations

[X] Final Calculations

[] Check Calculations (On Calculation Dated)

[] Void Calculation (Reason Voided)

Incorporated in Final Drawings?

This calculation verified by independent "check" calculations?

[] Yes [X] No

[1 Yes [X] No

Original and Revised Calculation Approvals:

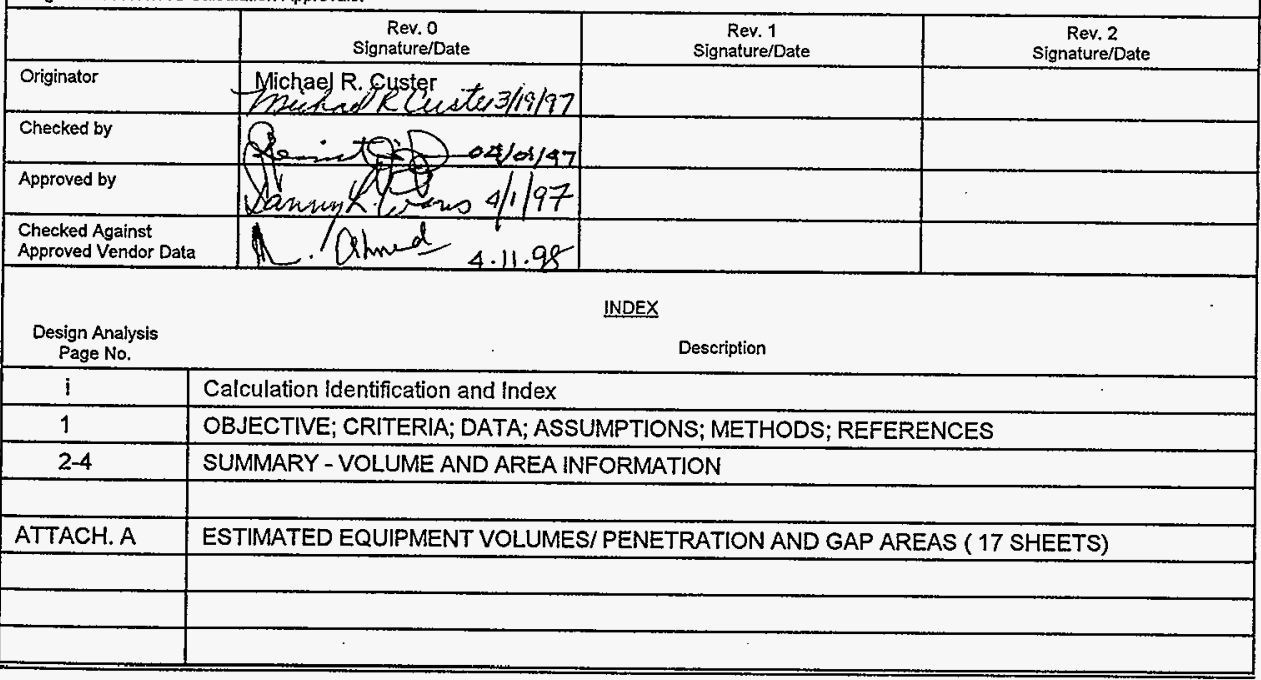


DESIGN ANALYSIS

Client: NUMATEC HANFORD CORPORATION

Subject: W-320 PIT VOLUMES AND IN-OUT AREAS

Location: TANK 241-C-106 and 241-AY-102, $200 E$
Page No.: 1 of 4

WO/Job No. E09142/W-320

Date: $\quad 03 / 12 / 97 \quad$ By: M. R Custer MRC

Checked: 04/01/97 By: N. L. JupLo

Revised:

By:

OBJECTIVE:

The objective of this calculation is to determine the net volumes and air flow areas in and out of pits $06 \mathrm{~A}$ and $06 \mathrm{C}$ at Tank 241-C-106 and pits 02A and 02E AT tANK 241-ay-102.

CRITERIA:

1. N/A

DATA:

1. N/A

ASSUMPTIONS:

1. N/A

METHODS:

1. N/A

\section{REFERENCES:}

1. H-2-818448, Sh 1

2. H-2-818450, Sh 1

3. $\mathrm{H}-2-818453$, Sh 1 thru 3

4. $\mathrm{H}-2-818454$, Sh 1 thru 2

5. $\mathrm{H}-2-818490$, Sh 1 thru 2

6. $\mathrm{H}-2-818494, \mathrm{Sh} 1$ thru 2

7. $\mathrm{H}-2-818496, \mathrm{Sh} 1$ thru 6

8. $H-2-818500$, Sh 1

9. $\mathrm{H}-2-818501$, Sh 1

10. $\mathrm{H}-2-818502$, Sh 1

11. $\mathrm{H}-2-818503$, Sh 1

12. $\mathrm{H}-2-818505$, Sh 1

13. $\mathrm{H}-2-818508$, Sh 1

14. $\mathrm{H}-2-818515$, Sh 1

15. $\mathrm{H}-2-818518$, Sh 1

16. $\mathrm{H}-2-818524$, Sh 1 and 2

17. $\mathrm{H}-2-818526$, Sh 1 and 2

18. $\mathrm{H}-2-818537$, Sh 1

19. H-2-818542, Sh 1

20. $\mathrm{H}-2-818543$, Sh 1

21. $\mathrm{H}-2-818544$, Sh 1 and 2

22. $\mathrm{H}-2-818545$, Sh 1

23. $\mathrm{H}-2-818549$, Sh 1 


\section{DESIGN ANALYSIS}

client: NUMATEC HANFORD CORPORATION

subject: W320 PIT VOLUME AND IN-OUT AREAS

Location: 241-C-106 AND 241-AY-102

SUMMARY - VOLUMES AND IN-OUT AREAS: (Refer to Attachment A)

TANK 241-C-106, PUMP PIT (PIT 06A)

- PIT FREE VOLUME

a. PIT VOLUME $=14.5 \mathrm{ft} \times 11.0 \mathrm{ft} \times 6.4 \mathrm{ft}=1020 \mathrm{cu} \mathrm{ft}$

b. INSTALLED EQUIPMENT VOLUME $=41 \mathrm{cu} \mathrm{ft}$

FREE VOLUME $=979 \mathrm{cu} \mathrm{ft}$

- VENTILATION FLOW PATH AREA, PIT TO TANK

a. 6" HIGH CAPACITY DRAIN $=28.3 \mathrm{sq}$ in $\quad$ (Winch)

b. OTHER PENETRATIONS $=$ NONE

TOTAL FLOW AREA, PIT TO TANK $=28.3 \mathrm{sq}$ in

- VENTILATION FLOW PATH AREA, PIT TO ATMOSPHERE

a. WINCH DRIVE PORT $=9.5 \mathrm{sq}$ in

b. COVER BLOCK GAPS (NORTH SIDE) $=9.0 \mathrm{sq}$ in

c. COVER BLOCK GAPS (SOUTH SIDE) $=12.0 \mathrm{sq}$ in

TOTAL FLOW AREA, PIT TO ATMOSPHERE:

Maximum $=30.5 \mathrm{sq}$ in

Minimum $=9.5 \mathrm{sq}$ in

TANK 241-C-106, SLUICE PIT (PIT 06C)

- PIT FREE VOLUME

a. PIT VOLUME $=9.0 \mathrm{ft} \times 8.5 \mathrm{ft} \times 7.6 \mathrm{ft}=581 \mathrm{cuft}$

b. INSTALLED EQUIPMENT VOLUME $=5.0 \mathrm{cu} \mathrm{ft}$

FREE VOLUME $=576 \mathrm{cu} \mathrm{ft}$

- VENTILATION FLOW PATHAREA, PIT TO TANK

a. 6" HIGH CAPACITY DRAIN = $28.3 \mathrm{sq}$ in (Sluicer)

b. OTHER PENETRATIONS $=$ NONE 


\section{DESIGN ANALYSIS}

Client: NUMATEC HANFORD CORPORATION

Subject: W320 PIT VOLUME AND IN-OUT AREAS

Location: 241-C-106 AND 241-AY-102
Page No. 3 of 4

WO/Job No. E09142/ W-320

Date: $\quad 03 / 12 / 97$

By: M.R Custer MRC

Checked: $04 / 01 / 97$

Revised:
By: N.J. JUPLO

By:

- VENTILATION FLOW PATH AREA, PIT TO ATMOSPHERE

a. COVER BLOCKS (NORTH SIDE) $=10.0 \mathrm{sq}$ in

b. COVER BL.OCKS (SOUTH SIDE) $=7.5 \mathrm{sq}$ in

TOTAL FLOW AREA, PIT TO ATMOSPHERE:

MAXIMUM $=17.5 \mathrm{sq}$ in

MINIMUM $=0.0 \mathrm{sq}$ in, however assume $1.0 \mathrm{sq}$ in (Due to incomplete sealing)

TANK 241-AY-102, PUMP PIT (PIT 02A)

- PIT FREE VOLUME

a. PIT VOLUME $=12.0 \mathrm{ft} \times 8.0 \mathrm{ft} \times 5.0 \mathrm{ft}=480 \mathrm{cu} \mathrm{ft}$

b. INSTALLED EQUIPMENT VOLUME $=7.7 \mathrm{cu} \mathrm{ft}$

FREE VOLUME $=472 \mathrm{cu} \mathrm{ft}$

- VENTILATION FLOW PATH AREA, PIT TO TANK

a. 6" HIGH CAPACITY DRAIN $=28.3 \mathrm{sq}$ in $\quad$ (Distributor)

b. OTHER PENETRATIONS $=$ NONE

TOTAL FLOW AREA, PIT TO TANK $=\mathbf{2 8 . 3} \mathrm{sq}$ in

- VENTILATION FLOW PATH AREA, PIT TO ATMOSPHERE

a. VALVE HANDLE - $1 / 16$ in gap @ 3 in. HOLE $=0.9 \mathrm{sq}$ in $\times 2=1.8 \mathrm{sq}$ in

b. COVER BLOCKS GAPS (EAST/ WEST SIDES) $=107.0 \mathrm{sq}$ in

c. $3^{*}$ DIA. PENETRATION (DRAIN SEAL) $=0.6 \mathrm{sq}$ in

TOTAL FLOW AREA, PIT TO ATMOSPHERE:

MAXIMUM $=108.2 \mathrm{sq}$ in

MINIMUM $=1.2 \mathrm{sq}$ in

TANK 241-AY-102, SLUICE PIT (PIT 02E)

- PIT FREE VOLUME

a. $P I T$ VOLUME $=8.0 \mathrm{ft} \times 6.0 \mathrm{ft} \times 7.0 \mathrm{ft}=336 \mathrm{cuft}$

b. INSTALLED EQUIPMENT VOLUME $=43.0 \mathrm{cu} \mathrm{ft}$ 


\section{DESIGN ANALYSIS}

Client: NUMATEC HANFORD CORPORATION

subject: W320 PIT VOLUME AND IN-OUT AREAS

Location: 241-C-106 AND 241-AY-102
Page No. 4 of 4

WO/Job No. E09142/W-320

Date: $03 / 12 / 97$

By: M.R Custer /RRC

Checked: $04 / 01 / 47$

Revised:

- VENTILATION Flow PATH AREa, PIT TO tank

a. 6" HIGH CAPACITY DRAIN $=28.3 \mathrm{sq}$ in (Winch)

b. OTHER PENETRATIONS $=$ NONE

TOTAL FLOW AREA, PIT TO TANK $=\mathbf{2 8 . 3} \mathbf{s q}$ in

- VENTILATION FLOW PATH AREA, PIT TO ATMOSPHERE

a. WINCH DRIVE PORT $=9.5 \mathrm{sq}$ in

b. COVER BLOCK GAP (NORTH SIDE) $=9.1 \mathrm{sq}$ in

c. COVER BLOCK GAP (NORTH SIDE) $=10.3 \mathrm{sq}$ in

TOTAL FLOW AREA, PIT TO ATMOSPHERE:

MAXIMUM $=28.9 \mathrm{sq}$ in

MINIMUM $=9.5 \mathrm{sq}$ in 
ATTACHMENT A

CALCULATION W320-27-047, Revision 0

$($ TOTAL PAGES $=18, \quad$ COVER PAGE + 17) 
FLUOR DANIEL NORTHWEST

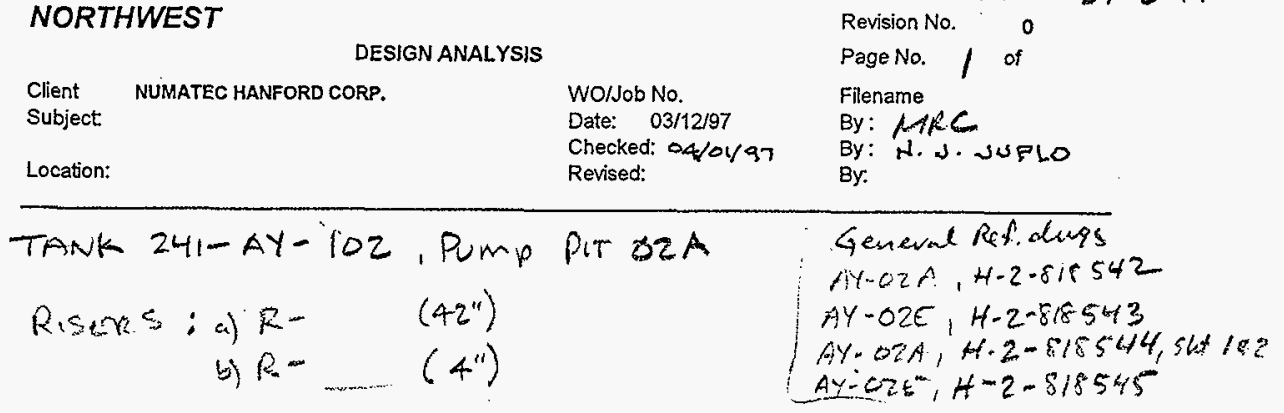

ATTACHMENT A Calc. No. W320-27-04t\% Revision No. Page No.

Filename

By: ARC

By:

c) Flowio ortin

2) Junpeve Asosentias:

a) $H-z-818501$ w/ $u-11$ cenvecters

b) $H-2-818502$ w/ $u-3 \$ 4-8$ connedens

3) ERvitmenT:

a) Distrinet or $(H-2-818537)$

4) contarn Bwelts (Hoz-8! $\left.454,5 H_{1} 2\right)$

TATH 241-AY-102, SWUIGE PIT OZE

1) Risers:

a) $R=(34 ")$

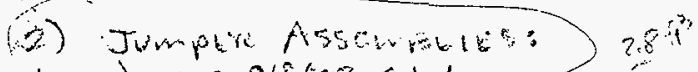

a) $4-2-81 \hat{8} 503$ sut. 1

(3) terisment:

a) Winem Assumblet (H-2.818494-2)

b) SLute: Bustern Purap

c) PIT COOLING FRN COIG LNIT/SuPPOAT

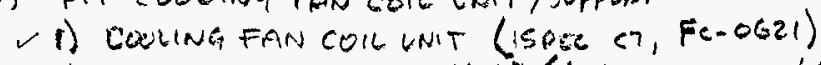

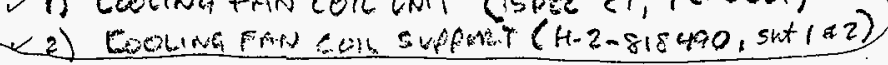

4) Coven Bloeks $(H-2-818454,542)$

HNF-2477, Rev. 0

Page D-7 
FLUOR DANIEL

NORTHWEST
DESIGN ANALYSIS

Client Subject

NUMATEC HANFORD CORP.

Location:
ATTAGHMENT A Calc. No. Wis20-27-647 Revision No.

Page No. 2 of Filename

By: $A A C$

By: N. 2 Jueco

By.

TANKK 241-C-106, PUMP PIT OGA

Rof dwas

1) Kats:

a) $R-5\left(4^{\prime \prime}\right) \quad R-7$ AT $06 A$ H-2-8185246 sht 1,2
P.T 060402.819526 sht 1,2

b) $R-6 \quad\left(12^{\prime \prime}\right)$

g) $R=9\left(36^{\prime \prime}\right)$

d) FLOOR DRAIN

(2) Jump ACERm wLLES:

a) $H .2-818505$

b) $H+2=818508$

3) EQUifMENT:

a) SLUREY BOOSTER PUMP (h-2-515500)

b) coinen Asstmbly (H-2-818494)

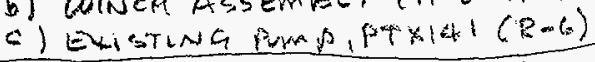

4) Eever block (GAPS/Pendrations): H-2-8184-8, SMS

a) Ertict. ÁCOESS SLOT

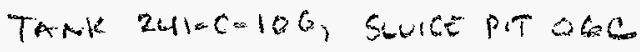

1) Risers: $R-3\left(12^{\prime \prime}\right), R-4\left(4^{\prime \prime}\right)$, floor DRAIN

2) Jumpere asse...

a) $4-2-818515$

b) $14-2-818516$

3) EquIPMENT':

a) Sulicet Asesemply (H-2.815549)

4) Cover block (Gaps/ PENETRATtens): H-z-818448, sht.2

HNF-2477, Rev. 0

Page D-8 
FLUOR DANIEL

NORTHWEST

Client

Subject

NUMATEC HANFORD CORP.

Location:
ATTACMMENT A

Calc. No. W320- 27-047

Revision No. 0

Page No. 3 of

Filename

WOJJob No.

By: Ather

Checked: $34 / 01 / 87$

By: W.S. SUPLO

By:

ESTIMATED VolüMES:

1. Distrientog: (241-AY-102, PIT OZA)

a) ADAPTkR RLATE, $\pi\left[\left(51^{\prime \prime}\right)^{2}-\left(23^{10^{2}}\right)\right]\left(1,5^{\prime \prime}\right)$

$$
=2140.6 \mathrm{in}^{3}
$$

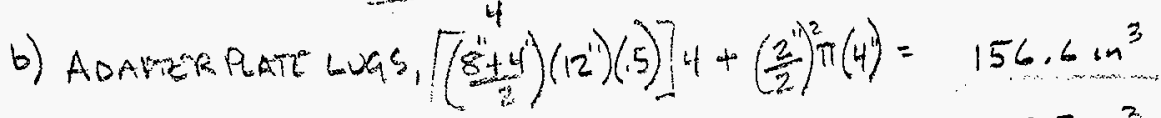

c) Trunions, $2\left[(4 / 2)^{2} \pi \times 5^{11}\right]$

$=125.7 \mathrm{in}^{3}$

d) Dorverso, $\left(\right.$ Totar Lencim, $\left.18^{\prime \prime}\right), 18^{\prime \prime}\left(2^{\prime \prime} / 2\right)^{2} \pi(2)$

$$
=113.1 \mathrm{in}^{3}
$$

e) $\mathbb{R}\left(3, \pi\left[\frac{\left(36^{2}-28^{2}\right)}{4}\left(1.5^{11}\right)\right.\right.$

$=603.2 \mathrm{in}^{3}$

f) $R(8), \pi\left[\frac{\left.36^{2}-47 / 8^{2}\right]}{4}-\left(1.5^{11}\right)\right.$

$=1498.8 \mathrm{in}^{3}$

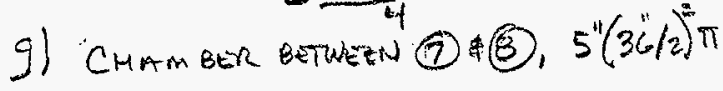

$=5089.4 \mathrm{~m}^{3}$

h) $4^{\prime \prime} \%$ no 336 E pupe, $11.5^{\prime \prime}(4 / 2)^{2} \pi$

$=\frac{144.5 \mathrm{in}^{3}}{3}$.
$=32.4 \mathrm{in}^{3}$

i) $2^{\prime \prime} \%$ noz3ut \& ppe, $10.3(2 / 2)^{2} \pi$

TOIAC VOLUME $=\frac{9904.3 \mathrm{~m}^{3}}{1728}=5.7 \mathrm{Fq}^{3}$

HNF-2477, Rev. 0

Page D-9 
FLUOR DANIEL

NORTHWEST

Client NUMATEC HANFORD CORP.

Subject:

Location:
ATTACHMENT A

Calk. No. W320-27.047

Revision No. 0

Page No. 4 of

Filename

WO/Job No.

By: Afr es

- Checked: 04101/97 By: N. J. Jus Lo

Revised:

EST UnATZO VOLUMES: (CONT.)

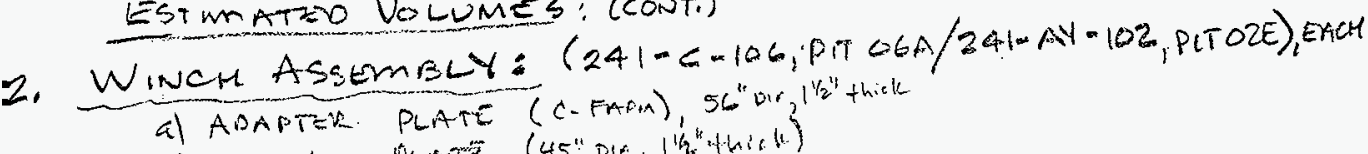

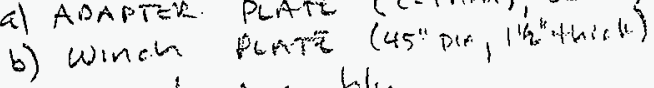

c) win din Assembly

a) Volume $=\left(\frac{50}{2}\right)^{2}+1+15^{\prime \prime}=3695 \mathrm{w}^{3}$

b) Volume $=\left(\frac{45}{2}\right)^{2} \pi \times 1.5^{\prime \prime}=2386 \mathrm{~m}^{3}$

c) Wench Acoscombly:

1) I"Bosis PhAt": $23,17^{\prime \prime} \times 32.25^{\prime \prime} \times 1 "=5.15,0 \mathrm{~m}^{3}$

2) Gear bee : $13.30^{\prime \prime} \times 27.25^{\prime \prime} \times 31.42^{\prime \prime}=11,387.0 \mathrm{~m}^{3}$

3) Shearew/cable: $\left(\frac{28,0}{2}\right)^{2} \pi\left(3,75^{\prime \prime}\right)=2309.0 \mathrm{im}^{3}$

A) Id len sheave: $\left(\frac{5^{\prime \prime}}{2}\right)^{2} \pi\left(2,5^{\prime \prime}\right)=49.1 \mathrm{~m}^{3}$

5) HANFarios unDER: $\left(\frac{4^{\prime}}{2}\right)^{2 \pi}\left(6^{\prime \prime}\right)=75.4 \mathrm{~m}^{2}$

c) PRIVE Guide: $\left(\frac{5}{2}\right)^{2} n\left(8^{\prime \prime}\right)=157.01 \mathrm{in}^{3}$ 7) Pillow Block/soppont: $16^{61} \times 2.75^{\prime \prime} \times 13.25^{11}=583.0 \mathrm{~m}^{3}$

8) DRWE SMAFT" $82.88^{\prime \prime} \times\left(\frac{11}{2}\right)^{2} \times \pi=65.0 \mathrm{in}^{3}$

9) LIETING WUGS:

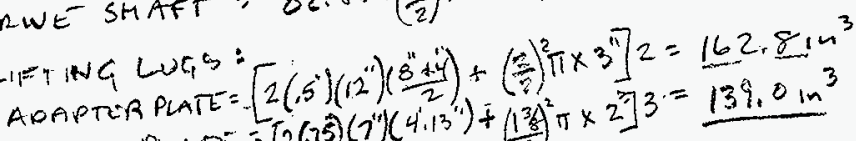

Wined Pare $=\left[2(.53)\left(7^{4}\right)\left(4^{2} .13^{4}\right)+\left(\frac{38}{2}\right)^{2} \pi \times 2^{3}\right]^{3}=139.0 \mathrm{~m}^{3}$

TOTAL Volume: $21,523.0 \mathrm{~m}^{3}=12.5 \mathrm{ft}^{3}$

HNF-2477, Rev. 0

Page D-10 
FLUOR DANIEL

NORTHWEST
AtTrimiment A Call. No. W $320=27-047$ Revision No. Page No. 5 of Filename By: 19126

By.

Estimated volumes: (CONT.)

3.0)Bo0 ster Pump: (241-C-106, PT O6A/241-AY-102 PIT OZE), ERt

1) Motor portion: $60^{\prime \prime} \times\left(\frac{26}{2}\right)^{\prime 2}=31,856.0 \mathrm{~m}^{3}$

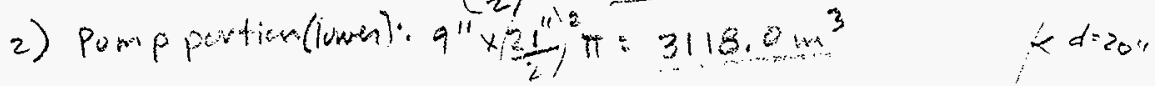

3) Pump portion (upper):

$$
\frac{\pi\left(20^{2}-18.5^{2}\right)}{4}\left(40^{\circ}\right)+\left(\frac{15}{2}\right)^{2} \pi\left(40^{\prime \prime}\right)=3581 \mathrm{~m}^{3}
$$

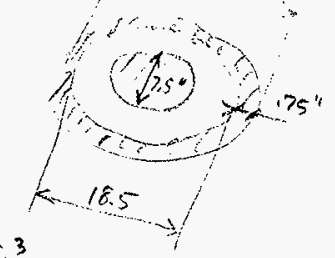

$$
\text { TOTAL VOLUTE }=\frac{38565 \mathrm{~m}^{3}}{1725}=22.3 \mathrm{ft}^{3}
$$

$$
A=\pi\left(a^{2}-d_{1}^{2}\right)
$$

3.6) Existing PuMP PTX146(R-6)

$$
\begin{aligned}
& \text { Volume an P.T }=10^{\prime \prime} \phi \cdot \times 44^{\prime \prime},\left(10^{\prime \prime} / 2\right)^{2} \pi\left(44^{\prime \prime}\right)=3455.8 \mathrm{~m}^{3} \\
& \text { BAsE Pe, } 11^{\prime \prime} \times 28^{\prime \prime} \phi=923.6 \mathrm{~m}^{3} \\
& 104 \times 13 \text { LU }(2), 20^{\circ} \times 3.83(2)=153.2 \mathrm{in}^{3} \\
& \text { Total volume }=\frac{4532,6}{1728}=2 \text {. } \\
& =2.6 \mathrm{ft}^{3}
\end{aligned}
$$

HNF-2477, Rev. 0
Page D-11 
FLUOR DANIEL

NORTHWEST

DESIGN ANALYSIS

Client NUMATEC HANFORD CORP.

Subject.

Location:
Wo/Job No.

Date: $03 / 12 / 97$

Checked: $04 / 01 / 97$

Revised:

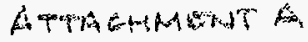

Call. No. W320-27-047

Revision No. 0

Page No. 6 of

Filename

By: AiRt.

By: N. S. SUPLO

By.

ESTIMATES VOLUMES: (CONT.)

4. SuUlaere Assembly:

a) Fee plate assembly:

(43) $\left.1^{\prime \prime}\left(13^{\prime \prime} \times 13.5^{\prime \prime}\right)+(211 / 2)^{2} \pi+\left(5.5^{\prime \prime} / 2\right)^{2} \pi\right]$

(6) $1.75^{\prime \prime}\left[\left(13 \times 13,5^{\prime \prime}\right)+\frac{\left.\pi\left(21^{\prime \prime}-116^{\prime \prime 2}\right)\right]}{4}\right]$

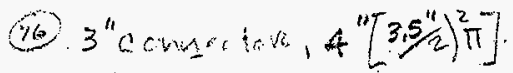

$3^{\prime \prime}$ pipe,$\left[(3.5 / 2)^{2} \pi\left(7.5^{\prime \prime}+4^{4}\right)\right]$

(19) $4^{11}$ N. $033 E L, 4^{4}\left[(4.5 / 2)^{2} \pi\right]$

$4^{\prime \prime} P$ PE , $\left[(4.5 / 2)^{2} \pi\left(9.8 i^{41}+2.5^{4}\right)\right.$

L

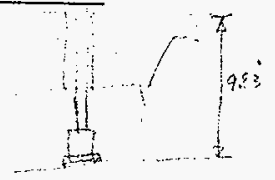

(61) $12^{4}$ PIPE w/HOLEC $\left(82.4 \mathrm{~m}^{3}\right)$ $12^{\prime \prime}$ P. PE (CMAMBEt'V Vat GM EE $=(12.75 / 2)^{2} \pi\left(16-2.75^{\prime \prime}\right)$. $=1691.7 \mathrm{in}^{3}$

(4) $3^{\prime \prime} R, 13.0^{\prime \prime} \times 13.25^{\prime \prime} \times 3^{\prime \prime}$

(6) TUBing, 43\%O.D $\times 4 / 4 I .0, \pi\left(4.75^{\prime \prime} / 2\right)^{2} \times 44^{\prime \prime}$

(62) Contact, $5\left[9^{11} \times 13.0^{\prime \prime} \times .5^{\prime \prime}\right]$

$=545.6 \mathrm{~m}^{3}$

$=728.3 \mathrm{~m}^{3}$

$=38.4 \mathrm{in}^{3}$

$=110.6 \mathrm{in}^{3}$

$=63.6 \mathrm{~m}^{3}$

$\times 195.9 \mathrm{in}^{3}$

(12) BAL, $(1.38 / 2)^{2} \pi\left[9.4^{\prime \prime}+2\left(12^{\prime \prime}\right)\right]$

(47) $4^{\prime \prime} R, 4^{\prime \prime}\left(12.5^{\prime \prime}\right)\left(13^{\prime \prime}\right)$

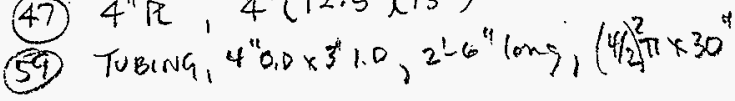

$=1691.7 \mathrm{in}^{3}$

$=516.8 \mathrm{in}^{3}$

$=779.7 \mathrm{im}$

$=292.5 \mathrm{~m}^{3}$

$=49.9 \mathrm{~m}^{3}$

$=650.01 \mathrm{n}^{3}$

$=\frac{377.0}{3}$

$647-10$
$38-4$
$3 \frac{9}{9-6}$
$\frac{3-0}{7 \cdot 6}$

$$
\begin{aligned}
\text { TOTAL VOLUME } & =\frac{6040.0 \mathrm{im}}{1728} \\
& =3.5 \mathrm{ft}^{3}
\end{aligned}
$$

HNF-2477, Rev. 0

Page D-12 
FLUOR DANIEL

NORTHWEST

DESIGN ANALYSIS

Client

Subject

NUMATEC HANFORD CORP.

Location:
Attachment a Call. No. W $320 \cdot 27 \cdot 047$

Revision No.

Page No. 7 of

Filename

By: $M R C$

By: W.J. JUPLE

Equipment VolumEs: (CONT.)

5. Pit CoOLIng Fan COIL/Support: (241-AY-OzE)

a) Coons FAns coll, $13.25^{\prime \prime} \times 18.5^{\prime \prime} \times 36^{\prime \prime}($ verses $)=8824.5 \mathrm{~m}^{3}$

b) 3D1"ppivg. $(95.17 " 97.17)(1.32 / 2)^{2} \pi$

$=263.2 \mathrm{ma}^{\circ}$

d) Supporter STRUCTURE,

(29) $C 4 \times 5,4,1.54 \mathrm{~m}^{2}(131.6 \mathrm{~m})$

$=202.7 \mathrm{in}^{3}$

(30) $\angle 21 k_{2} \times 2 / 2 \times 1 "+\left(8^{\prime \prime}(9), 1.19 \mathrm{~m}^{2}\left(8^{\prime \prime}\right)\right.$

(3) $413 \times i^{1 / 2} \times 14\left(6^{\prime \prime} 69\right), 0.68 \mathrm{~m}^{2}\left(6^{\prime \prime}\right)$

$=9.5 \mathrm{~m}^{3}$

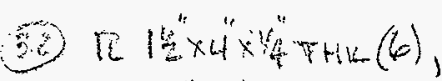

$=4.1 \mathrm{~m}^{3}$

$=9.0 \mathrm{~m}^{3}$

(33) R1 2 " $2 \times 4 " \times 1 / 2 " T H L(1)$

$=25.0 \mathrm{~m}^{3}$

d) I"P. PE fittings:

(3) $8,1^{\prime \prime S C H} .40,90^{\circ} L R, 8\left(2.4^{\prime \prime}\right)\left([1.32 / 2]^{2} \pi\right)$

$=26.3 \mathrm{~m}^{3}$

(39) $4,1^{\circ} \mathrm{sen}, 40.45^{\circ} L R, 4(2.4 / 2)\left([\pi 32 / 2]^{2} \pi\right)$

$=6.6 \mathrm{~m}^{3}$

$=6.3 \mathrm{~m}^{3}$

e) PIns: TOTAL LATH $=8^{n}(1 / / 2)^{2} n$

HNF-2477, Rev. 0
Page D-13 
FLUOR DANIEL

NORTHWEST
DESIGN ANALYSIS

Client NUMATEC HANFORD CORP.

Location:
ATTACMMENT A Calc. No. W320-27.049 Revision No. Page No. 8 of Filename By: AARC

By:

ESTIMATE VQWUMES: (CONT.)

6. Jumpere Assmberes (241-AY-10\%,PIT OZA)

9) H-2-818501: AY-02A-U11-A-(C)

(919) $4^{\prime \prime},(4.5 / 2)^{2} \pi\left[\left(65^{\prime \prime}-12^{\prime \prime}\right)+\left(21^{\prime \prime}-4^{\prime \prime}\right)+\left(19^{\prime \prime}=12\right)^{\prime \prime}\right)+\left(15^{\prime \prime}-6\right)=1954,6 \mathrm{~m}^{3}$

(2)

$$
\left.+6^{\prime \prime}+9.4^{\prime \prime}(3)+4.7^{\prime \prime}\right]
$$

(5) Volume 6 "6 $\times 6^{\prime \prime}(\operatorname{lng},(6 / 2) \pi(6)(2)$

(10) $2^{\text {"P.pe }, ~}\left(2,38^{\prime \prime} / 2\right)^{2} \pi\left(20^{\prime \prime}\right)$

(11) $4^{4} \phi \times 104,(4 / 2)^{2} \pi\left(10^{10}\right)+5.0($ misc $)$

$$
\begin{aligned}
& =339.3 \mathrm{~m}^{3} \\
& =890 \mathrm{~m}^{3} \\
& =130.7 \mathrm{~m}^{3}
\end{aligned}
$$

b) H-2-81850Z: AY-02A-43-U8-B

(32) $2^{\prime \prime} p_{1} x_{0},\left[\left(33^{\prime \prime}-3\right)+6 \pi^{\prime \prime}+\left(43^{\circ}+3^{\prime \prime}\right)+6 \pi^{\prime \prime}+(76-33]\right](2.38 / 2)^{2} \pi=544.6 \mathrm{~m}^{3}$

(3i) $4^{\prime \prime}$ PIPE, $\left(12^{\prime \prime}\right)(4,5 / 2)^{2} \pi$

(3) $2^{n} n E^{6}(5+180),(2.38 / 2)^{2} \pi\left(2^{\prime \prime}\right)$

$=198.9 \mathrm{~m}^{3}$

(18) $c 3 \times 4.1\left(A=1.21 \mathrm{n}^{2}\right)\left(21.5^{11}\right)$

$=8.9 \mathrm{~m}^{3}$

(19) $\angle 2 \times 2 \times Y_{4}\left(A=0.93 \mathrm{~mm}^{2}\right)\left(\mathrm{z}^{\prime \prime}\right)$

$=26.0 \mathrm{ma}^{3}$

(20) $\rightarrow\left(25,18.1^{3}+3.3+5.3+4.6+5.1+1.9\right.$

$=1,9 \mathrm{~m}^{3}$

(5) (7), $\left(3^{\prime \prime} / 2\right)(\pi)\left(4^{\prime \prime}\right)(2)$

$=38.2 \mathrm{~m}^{3}$

$=56.5$

TOTAL VOLUME: $=\frac{867 \mathrm{~m}^{3}}{1728}=0,50 \mathrm{fr}^{3}$

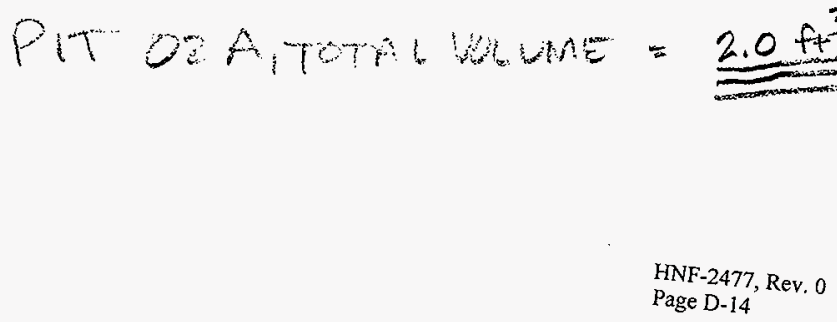


FLUOR DANIEL NORTHWEST
HNF-2477, Rev. 0

Page D-15

DESIGN ANALYSIS

Client NUMATEC HANFORD CORP.

Subject:

Location:
WOIJob No.

Date: $\quad 03 / 12 / 97$

Checked: $04 / 01 / 92$

Revised:
ATTACHMEQNT A Calc. No. W320-270047

Revision No. 0

Page No. 7 of

Filename

By: Aftect

By: 1.2 .34 PLO

By:

Estimates Vowmes: (cont)

7. Jumpere

a)

H-Z-818503, SH.1: AY-OZE-4Z-A- (B)

(5) $w 4 \times 13\left(A=3,83 n^{2}\right), 3.83\left(60^{\prime \prime} \times 2\right)$

(56) $33 \times 4,1\left(A^{2}=1,211^{\prime \prime}\right), 1,2,\left(73^{\prime \prime}+24^{\prime \prime}\right)$

(5) $3 \times 12 \times\left(30.5^{11} \pi\right)$

(1) $2 \log 33 \times 2 \times 14$

$5911 \% 5 \%(2)$

(6) $3 / 4 " 6 \times 2^{3 / 4}(4)$

(2) $16 \times 16^{\prime \prime}(2)$

(2) $3 / 8 \times 3 " \times 6 "$

(6) $3 / 8 " \times 66^{\prime \prime} \times 6.5^{\prime \prime}$

(5) "18" $\times 4 " \times 5$ "

(6) $31 / 8 \times 3 / 8$

(3) $5.5 \times 6 \times 3 \% 8$

(3) $13 / 8 \times 73 / 4 \times 3 / 8$

(9) $10 " \times 6.5 \times 3 / 8$

(1) $11 \times 8^{12} \times 8^{1 / 2}$

$\therefore$ (68) (6) 4" $10.8,\left(4.5^{\prime \prime} / 2\right) \pi\left[46^{\prime \prime}-L^{\prime \prime}(2)+\frac{12^{\prime \prime} \pi}{4}+(18-6)+\frac{12^{\prime \prime} \pi}{4}+\right.$

$$
\begin{aligned}
& =459.61 \mathrm{~m}^{3} \\
& =117.4 \\
& =143.7 \\
& =7.6 \\
& =19.9 \\
& =4.6 \\
& =6.3 \\
& =6.8 \\
& =14.6 \\
& =7.5 \\
& =2.9 \\
& =12.4 \\
& =4.0 \\
& =24.4 \\
& =72.3
\end{aligned}
$$

$$
\left.\left(45^{\prime \prime}-6^{\prime \prime}\right)+\frac{12^{4} \pi}{4}+\left(12^{\prime \prime}-6\right)\right]
$$

(67) $2^{\prime \prime} \operatorname{Arre,}\left(2.38^{\prime \prime} / 2\right)^{2} \pi\left[24^{\prime \prime}\right]$

(24) $4^{\prime \prime}, 3000$ RF, $10^{\prime \prime} \phi \times 1,5^{\prime \prime}(4)$

(75) $2 ", 300^{4} \mathrm{RF}, 6.5 " \phi \times 1.5^{\prime \prime}(4)$

(51) (20) $\left(5\right.$ " $\left.1 \times 6^{\prime \prime}+6^{\prime \prime} 6 \times 4^{\prime \prime}\right)$

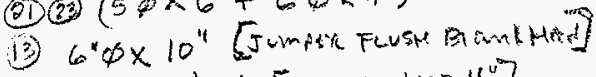

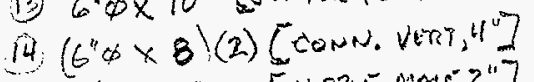

(15) $3^{4} \phi \times 4^{\prime \prime}$ [No33Le, Matci, 2 "]

$\theta$ MISCELL

$$
\begin{aligned}
& =1897.0 \\
& =106.8 \\
& =471.2 \\
& =199.1 \\
& =230.9 \\
& =282.7 \\
& =452.4 \\
& =28.2 \\
& =200.0
\end{aligned}
$$

TcF me wume $=4772 \mathrm{~m}^{3}=2.8 \mathrm{ft}^{3}$ 
FLUOR DANIEL

NORTHWEST

DESIGN ANALYSIS

Client

Subject:

NUMATEC HANFORD CORP.

Location:
ATTECHMENT

Calc. No. W320= Z7.044t

Revision No. 0

Page No. 10 of

Filename

WO/Job No.

By: 100

Checked: D4, or/97

Revised:
By: H.d. JUPLO

By:

Estimater Volwines: (can $\%)$

8. Jumper asstmblites (241-c-10G, pit 06A)

a) $H-2.818505: C .06 \mathrm{~A}: 9 \cdot \mathrm{A}$

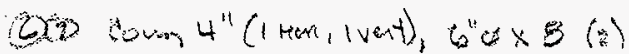

(13) Fucrumation" 4 " $5 " 6 \times 6 "$

(15) Presessemsen, co" $6 x y^{\prime \prime}$

(38) $C 6 \times 8.2\left(A=2.4 \mathrm{n}^{3}\right), 2.4\left(50^{\prime \prime}\right)$

(3) $1 / 4 \times 6 \times 8(2)$

(40.50 $21 / 4 \times 14 \times 3(4)$

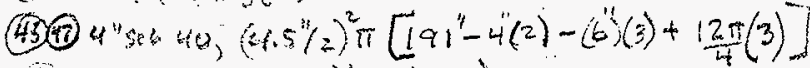

$46=18,440,\left(2,38^{\prime \prime} / 2\right)^{2} \pi\left(277^{\prime \prime}\right)$

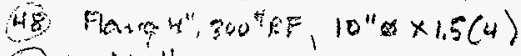

$\Theta$ mistent

$$
\begin{aligned}
& =120.0 \\
& =471.2 \\
& =200.0
\end{aligned}
$$$$
=452.414^{3}
$$$$
=117.8
$$$$
=113.1
$$$$
=120.0
$$$$
=24.0
$$$$
=7.5
$$$$
=3073.9
$$

TorAt volcime $=\frac{4700 \mathrm{~m}^{3}=2.7 \mathrm{FT}^{3}}{1728}$

b) $H-2-818508: C-06 A-B-(A)$

(43) $4 \times 13\left(A=3.83 \mathrm{~m}^{2}\right), 3.8^{2}\left(56^{\prime \prime}\right) 2$

(4i1) BAR $3 x^{\prime \prime} 12^{\prime \prime},\left(31^{\prime \prime}\right) \pi\left(3^{\prime \prime}\right)\left(.5^{\prime \prime}\right)$

(45) $2 / 2 \times 2 \%(4)$

(4) $\left(12^{4} \phi \times 5^{\prime \prime}\right)(2)$

(4) $(1 / 2 \times 3 \times 5)(3)$

504 "pipe, seh $40,(4.5 / 2)^{2} \pi\left(6^{\prime \prime}\right)$

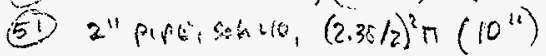

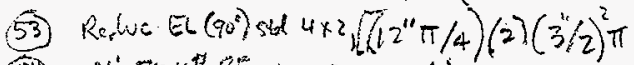

(5) $2^{\prime \prime} 300018 \%, 6.5^{\circ} \% \times 1.5(2)$

55 3"Pug, $(3.5 / 2)^{2} \pi\left(3^{\prime \prime}\right)$

$$
\begin{aligned}
& =429.0 \mathrm{~m}^{3} \\
& =146.0 \\
& =7.5 \\
& =17.7 \\
& =15.0 \\
& =95.4 \\
& =44.5 \\
& =133.2 \\
& =99.6 \\
& =28.9
\end{aligned}
$$

(cont.ig 11)

HNF-2477, Rev. 0

Page D-16 
FLUOR DANIEL

NORTHWEST

DESIGN ANALYSIS

Client

NUMATEC HANFORD CORP.

WO/Job No.

Subject:

Location:
Date: $03 / 12 / 97$

Checked: $04 / 01 / 97$

Revised:
ATTAENMENT A

Calc. No. W320-27-047

Revision No. 0

Page No. I/ of

Filename

By: $/ 2+1 / 2$

By: H. J. SUPLO

By:

Estimatero Voumes: (cont)

8.b) H-2. त18508: C-06A-B-(A)

$64,(3 / 5 \times 13 / 5 \times 7,75) 4$

(7) $2 \times 3 \times 6.5 \times 10^{11}$

$\Leftrightarrow 1 \times, 11 / 2 \times 9.5$

$91 x, 1 / 2 \times-1 \times 7$

(1) $4 x, 3 / 446 \times 3,5$

(14) Conn.vent 4 "

(1) Ne35LE HALE" 1 " $(4,5 / 2)^{2} \pi\left(6^{\prime \prime}\right)$

(17) (1) $12 \times 9 " 0$,

(91) $\rightarrow 32)=6 \times 6 " \times 6 "($ miso)

$$
\begin{aligned}
& =160.0 \\
& =48.8 \\
& =14.3 \\
& =24.5 \\
& =452.4 \\
& =\quad 75.4 \\
& =31.8 \\
& =216.0
\end{aligned}
$$

Totne voume $=\frac{1922}{172 \mathrm{C}}=1.1 \mathrm{ft}^{3}$

PIT OGA, tothl valume $=3.8 \mathrm{ft}^{3}$

HNF-2477, Rev. 0

Page D-17 
FLUOR DANIEL

NORTHWEST

Client NUMATEC HANFORD CORP.

Subject:

Location:
Attackment a

Calc. No. W320-27-047

Revision No.

Page No. 12, of

WO/Job No.

Filename

Date: $03 / 12 / 97$

By: MNC-

Checked: $04 / 01 / 97$

Revised:
By: N.S.JUPLO

By:

Estimntes Volumes: (cont)

9. Jumpere Acseunblies: (pit ogc)

a) $\mathrm{H}-2-818515 ; \mathrm{C}-06 \mathrm{C}-6-\mathrm{A}$

(2) $4^{\prime \prime} \cos n \cdot 2,\left[\left(6^{\prime \prime} \phi / 2\right)^{2} \pi \times 8^{\prime \prime}\right] 2$

(8) WFTWS, BAll, $1 / 2 " \phi \times 33^{\prime \prime} " q_{1}$

(19) $1 / 4 \times 6 \times 6$,

(12) $4^{4}$ pipt $5011.40,(4.5 / 2)^{2} \pi\left[56+\frac{12 \pi(2)]}{4}\right.$

$$
\begin{aligned}
& =452.4 \mathrm{in}^{3} \\
& =6.5 \\
& =9.0 \\
& =1190.4 \\
& \text { Tonab volume }=\frac{1658 \mathrm{~m}^{3}}{1728^{2}}=1.0 \mathrm{ft}^{3}
\end{aligned}
$$

b) $H-2-818516: C-O G C-8-8$

$503^{\circ} \operatorname{com} \cdot(2),[(5 " \phi / 2) \pi \times 6] 2$

(6) BAM

(3) $1 / 4 \times 5 \times 5$

(19) 3"Pire sct. 40, $(35,5) 2^{2} \pi\left[39+\frac{9 \pi}{4}(2)\right]$

$$
\begin{aligned}
& =\quad 335.6 \\
& =\quad 6.5 \\
& =\quad 6.3 \\
& =\quad 511.2 \\
& \hline
\end{aligned}
$$

$$
\text { TotAl volume }=\frac{759.6 \mathrm{in}^{3}}{1728^{2}}=0.4 \mathrm{ft}^{3}
$$

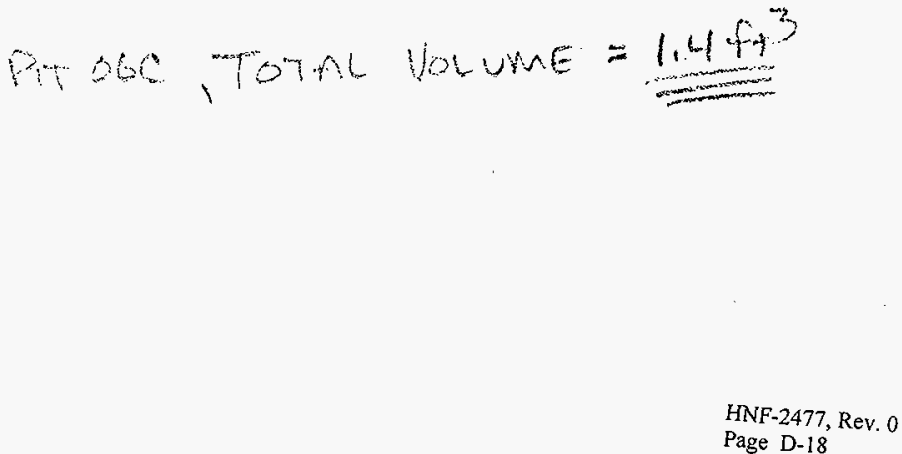


FLUOR DANIEL

NORTHWEST

DESIGN ANALYSIS

Client

Subject:

Location:
ATTACHMENT A Cali. No. W320.27.047 Revision No.

0

Page No. 13 of

Filename

By: NAC

By: N.W.UUPLO

By:

AIR FLOW AREAS): (PIT TO TANK)

1. 241-C-106, PIT ob eth (H-2-81852Z, SH. 1)

PENETRation lo.

$$
\begin{array}{ll}
R-5 & 4 " \phi \\
R-6 & 12 " \phi \\
R-7 & 12 " \phi \\
R-9 & 36^{\prime \prime} \phi
\end{array}
$$

Floor Drain (SUMP)
SIRE
WOJJob No.

Date: $03 / 12 / 97$

Checked: 04/01/47

Revised:

?.

$$
\text { 241-C-106, PIT OE C (H-2-818523,5H.1) }
$$

PEnEtration No.

$$
R-3
$$$$
R-4
$$

Floor $\frac{\sin 5}{12 " \phi}$

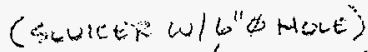

SEA LEO (SHIELD PLUG W/GASKET)

Pump HOSE DRAMU TO 6"sluICER HOLE

3. 241-AY-10\%, PIT DEA (H-Z-518EA\%)

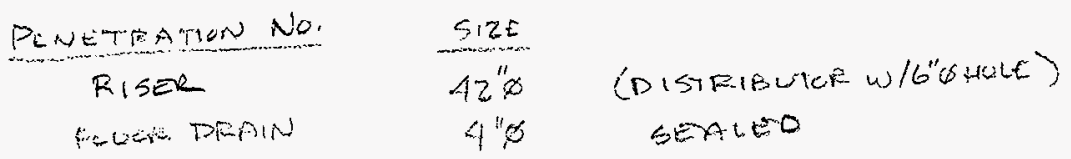

4. 241-AY-10\%, PIT OEE (H -Z-818543, SHT I AE)

PENETEATON ND

Risen

FLOE DRAT
$512 E$

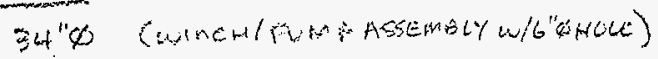

$4 " \phi$

Sentimo

HNF-2477, Rev. 0
Page D-19 
FLUOR DANIEL

NORTHWEST

DESIGN ANALYSIS

Client NUMATEC HANFORD CORP.

Subject:

Location:
ATTACHMENT A Call. No. W320-27.047 Revision No.

Page No. 14 of

Filename

By: MRC

By: N.S. JUFLO

Checked: $04 / 01 / 97$

Revised: By:

AIR LOW AREAS: PT TO AR

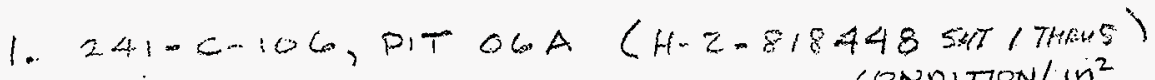

a) $3-8 " 0$ cameras polis,

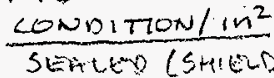

b) 1 - 3" VAin POET,

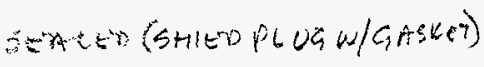

c) 1.- $6^{\prime \prime} \Phi$ whish PORT SLEEE: $9.5 \mathrm{in}^{2}$

d) $=-$ ate Ts (ELECTAERZ)

SEALED

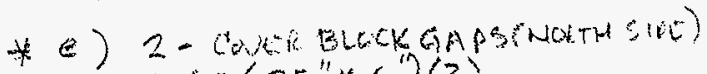

9 in $^{2}$ (MAX), (IF NOT ThO) $A:\left(75^{\prime \prime} \times 6\right)(2)$

$12 \ln ^{2}$ (may) (IF NOT TARO

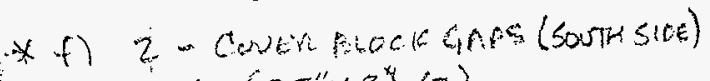
$A=\left(25^{\prime \prime} \times 8\right)(z)$

g) EXIST. 12" RISER

$S^{\circ} A C D$

h) PUMP PENETRATION

SEALED (SHIELD PULA W/GASKET)

*) During SLUicing OPERATION, THESE GAPS WOULD be TAPED ELIMINATTNG THIS ARE FOR ARR TO FlOW.

(XN) ALWAYS S OPEN

$$
\begin{aligned}
& \text { MAX. } q+12+9.5=30.5 \mathrm{~m}^{2} \\
& \text { MEN. O+0+9.5 }=9.5 . \mathrm{m}^{2}
\end{aligned}
$$

HNF-2477, Rev. 0

Page D-20 
FLUOR DANIEL

NORTHWEST

DESIGN ANALYSIS

Client

Subject:

NUMATEC HANFORD CORP.

Location:
Attachment a

Call. No. W320.27-04\%

Revision No.

Page No. 15 of

Filename

By: MRC

By: N.J.SUPLO

By:

A lR FLOW ARERS: PN TO AIR

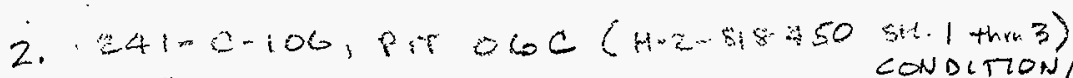

a) 3"Q VALUE port,

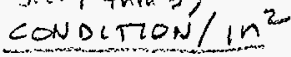

b) 8 "s crimean fort

SEALED (SHIELD PLUG W/GASKET)

c) $12^{\prime \phi}$ Subictio Part.

11

SETTLE

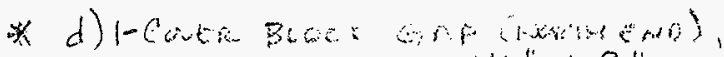

$10 \ln ^{20}$ (iF NOT TAPEO)

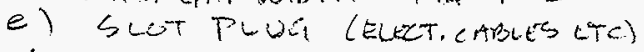

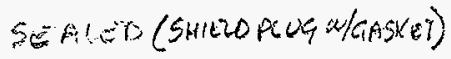

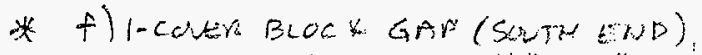

$7.5 \ln ^{2}$ (IF NOT TAPED)

max cine wis th = $114^{11} \times 6^{\prime \prime}$

* During sluicing operation these gaps would be Taped eliminating this area for air to flow.

$$
\begin{aligned}
& \text { MAX. }= 10.0+7.5=17.5 \mathrm{~m}^{2} \\
& \text { MIN. }= 0 \text { BUT ASSUME }=1.0 \mathrm{~m}^{2} \\
& \text { (DUE TO iNCOMPLETE } \\
& \text { SETTiNG) }
\end{aligned}
$$

HNF-2477, Rev. 0

Page D-21 
FLUOR DANIEL

NORTHWEST

DESIGN ANALYSIS

Client NUMATEC HANFORD CORP.

Subject:

Location:
Attagmaent a Call. No. W3 $20-27-044$ Revision No. 0 Page No. $/ 6$ of Filename

WOIJob No.

By: $M R C$

By: H.S.JUPLO

Checked: $04 / 01 / q 3$

Revised:

By:

AIR FlOW AREAS: PITTOABS

3. $241-A Y-102, P H=2 A(H-2-818453,5451+423)$

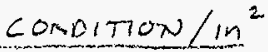

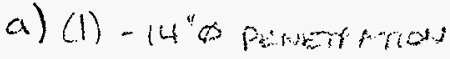

b) $(2)-3^{\prime} \phi$ pextontions

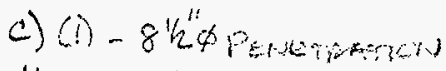

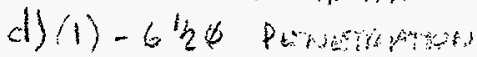

* $\Leftrightarrow$ - COVER BLOCK $\angle A B S$ (EAST/UEST) $1 / 2^{\prime \prime} \times 107^{\prime \prime}(2)$ $=10 \%$ in

f) New peNetranT QN (ECN For DRAIN (ZEAL) $A=0.6 \mathrm{in}^{2}$
SEALED (SHIELD PUT W/GASIET)

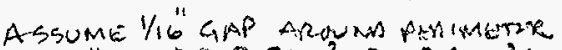
OF $3^{\prime \prime}$ MOLE $=0.30 \mathrm{~m}^{2} \times 2=0.6 \mathrm{~m}^{2}$ SEAR LV (SH

Tex trench/ OPEN / 107 in (TOTAC)

$A_{G A P}=0.6 \mathrm{~m}^{2}$

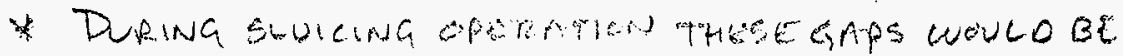
TAPED ELIMINATING THIS ARA FOR AIR TO FLOW,

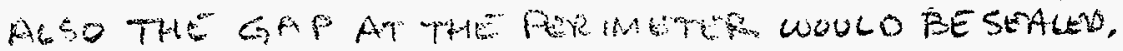

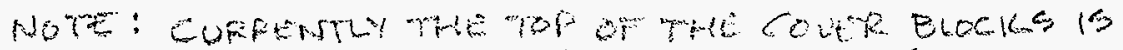
COUERE' WITH 3/4" LEAD SHEETING.

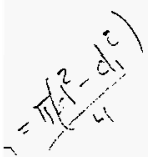

$$
\begin{aligned}
& M_{A X}=0.6+107+0.6=108.2 \mathrm{~m}^{2} \\
& M_{1 n}=0.6+0+0.6=1.21 \mathrm{~m}^{2}
\end{aligned}
$$

HNF-2477, Rev. 0

Page D-22 
FLUOR DANIEL

NORTHWEST
ATtACHMENT A Call. No. W320-27-047 Revision No. Page No. 17 of Filename By: ARKC By: N.W. JUPLO

By:

Client NUMATEC HANFORD CORP.

WO/Job No Date: $03 / 12 / 97$ Checked: o4tos/ 87

Location:

Revised:

AIR FlOW AREAS: PIT TO AIR

4. 241-AY-102, PITOZE (H-2-818454, SHT I M-144)

a) 36" $\phi$ PUMP PENETFATON

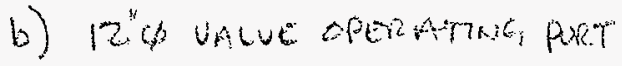

c) (2)-8" $\varnothing$ camera ports

Conormon/ $\mathrm{in}^{2}$

SEALED (SHIELD PLUG W/AASICA)

SEALER O (SHIELD RLUGW/GASHET)

SEALED (SHIELD PUVGW/GASKET)

**⿻一丿火 d) 6" $\phi$ WINCM DRive part

$$
\left(6^{\prime \prime} / 2\right)^{2} \pi-\left(1{ }^{\prime \prime} / 2\right)^{2} \pi-\left(3^{\prime \prime} \times 6^{\prime \prime}\right)=9.51 \mathrm{n}^{2}
$$

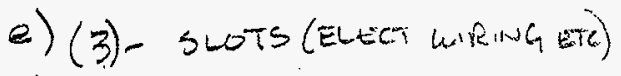

SEALED

* f) I - cover block Gap

$9.1 \mathrm{in}^{2}$ max. (IF NOT TAPED)

* g) 1- cover te block gap

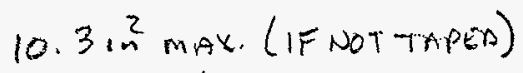

(SOVTH S1PE), 1.25 8.25 "

* During sluicing operation, these chaps would be taped ELIMINATING THIS AREA FOR AIR FLOW.

* Always open

$$
\begin{aligned}
& \text { MAY }=9.5+9.1+10.3=28.9 \mathrm{~m}^{2} \\
& \text { Min }=9.5+0+0=9.5 \mathrm{~m}^{2}
\end{aligned}
$$

HNF-2477, Rev. 0

Page D-23 
DISTRIBUTION SHEET

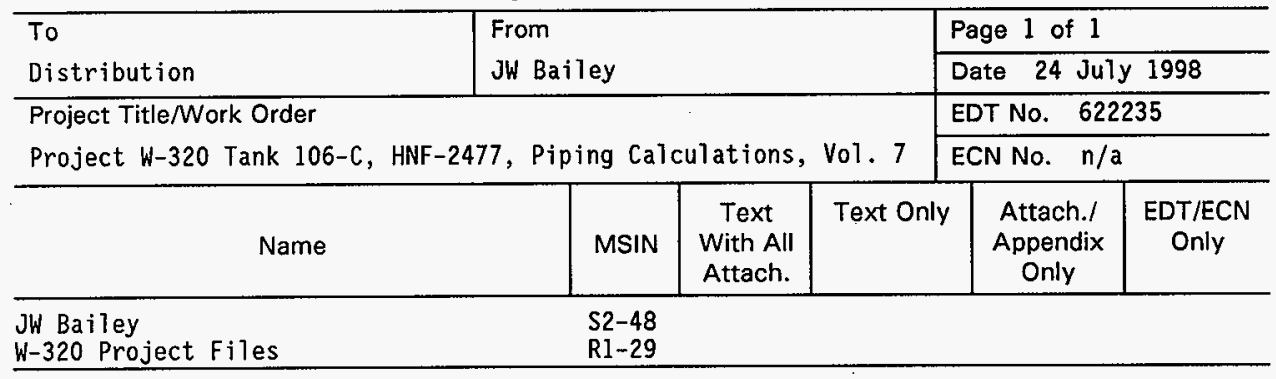

